\title{
Geochemical and Mineralogical Study of the Red Mountain Porphyry Copper-Molybdenum Deposit and Vicinity, Santa Cruz County, Arizona
}

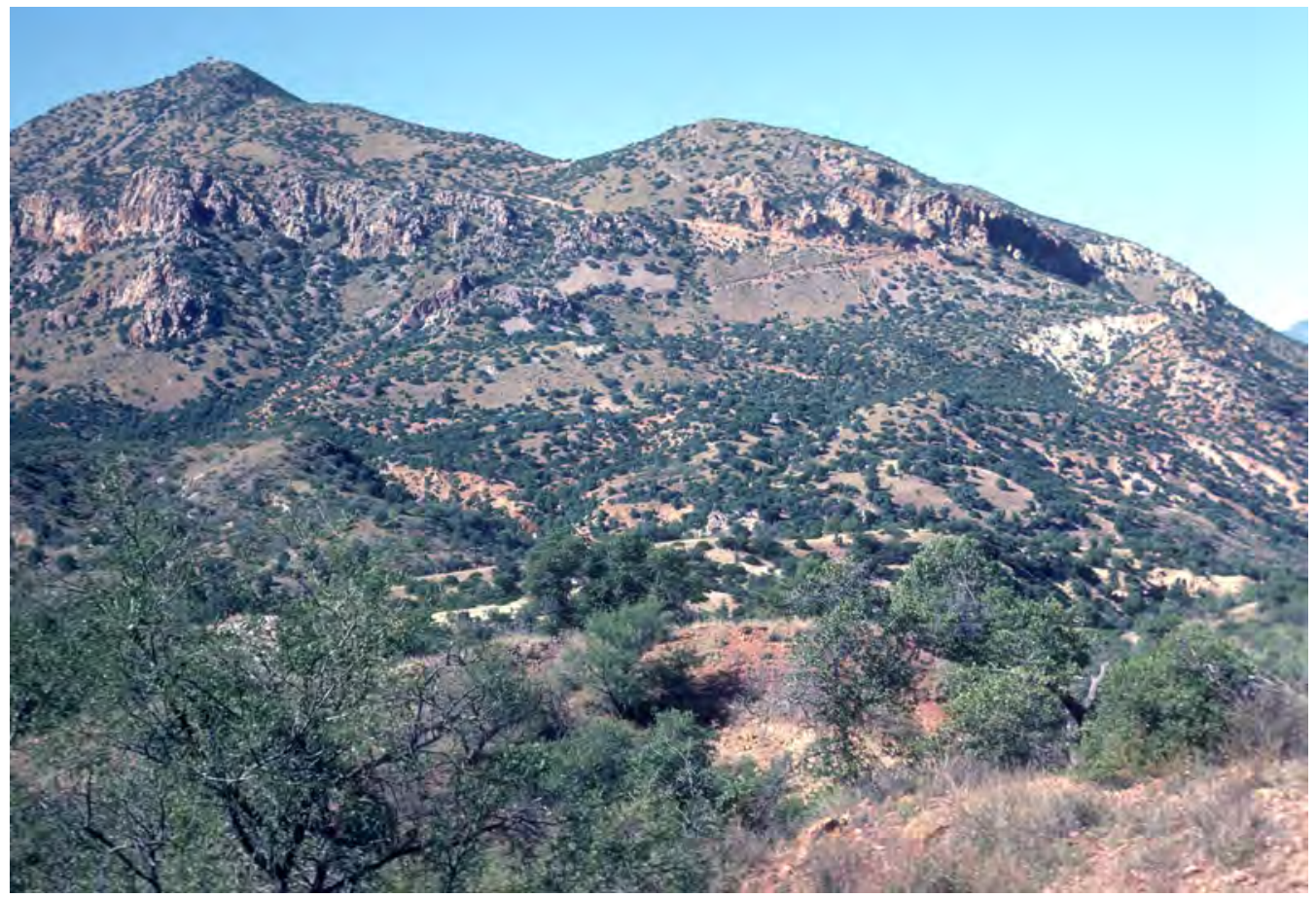

Scientific Investigations Report 2019-5077 
Cover. Red Mountain as viewed from the south. The white cliffs near the top of the mountain are exposures of the altered rhyolite tuff formation. The andesite formation comprises all of the area below the cliffs. 


\section{Geochemical and Mineralogical Study of the Red Mountain Porphyry Copper-Molybdenum Deposit and Vicinity, Santa Cruz County, Arizona}

By Maurice A. Chaffee

Scientific Investigations Report 2019-5077 


\title{
U.S. Department of the Interior DAVID BERNHARDT, Secretary
}

\author{
U.S. Geological Survey \\ James F. Reilly II, Director
}

\section{U.S. Geological Survey, Reston, Virginia: 2020}

For more information on the USGS - the Federal source for science about the Earth, its natural and living resources, natural hazards, and the environment-visit https://www.usgs.gov or call 1-888-ASK-USGS.

For an overview of USGS information products, including maps, imagery, and publications, visit https://store.usgs.gov.

Any use of trade, firm, or product names is for descriptive purposes only and does not imply endorsement by the U.S. Government.

Although this information product, for the most part, is in the public domain, it also may contain copyrighted materials as noted in the text. Permission to reproduce copyrighted items must be secured from the copyright owner.

Suggested citation:

Chaffee, M.A., 2020, Geochemical and mineralogical study of the Red Mountain porphyry copper-molybdenum deposit and vicinity, Santa Cruz County, Arizona: U.S. Geological Survey Scientific Investigations Report 2019-5077, 164 p., https://doi.org/10.3133/sir20195077.

Associated data for this publication:

Horton, J.D., San Juan, C.A., and Chaffee, M.A., 2020, Data to accompany U.S. Geological Survey Scientific Investigations Report 2019-5077-Geochemical and mineralogical study of the Red Mountain porphyry copper-molybdenum deposit and vicinity, Santa Cruz County, Arizona: U.S. Geological Survey data release, https://doi.org/10.5066/P9BS56JZ.

ISSN 2328-0328 


\section{Acknowledgments}

This report could not have been completed without the help of many individuals. W.P. Leedy and J.J. Quinlan, while employed by the Kerr McGee Corporation, offered helpful ideas, support, and encouragement during the early phases of this investigation. Many associates in the U.S.

Geological Survey helped collect, prepare, and (or) analyze the samples collected for this study. They include R.J. Fairfield, D.L. Fey, R.H. Hill, H.D. King, L.S. Laudon, H.M. Nakagawa, J.C. Negri, R.F. Sanzolone, J.D. Sharkey, S.J. Sutley, F.W. Tippitt, and E.P. Welsch. Commercial analyses were determined for the U.S. Geological Survey by ActLabs of Ancaster, Ontario, Canada. Reviews of earlier versions of this report by K.D. Kelley and P.G. Vikre were very helpful in improving this final version. 


\section{Contents}

Acknowledgments ........................................................................................................................

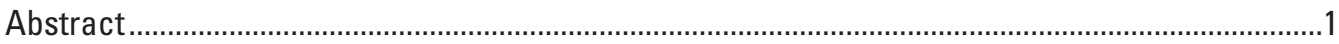

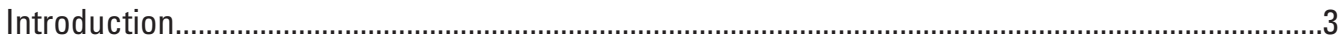

Location and Geologic Setting ..................................................................................................

Part A-Subsurface Geochemical and Mineralogical Studies of Core Sampling, Preparation,

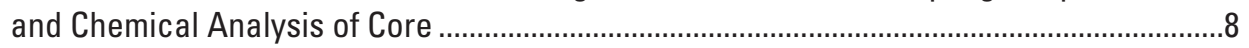

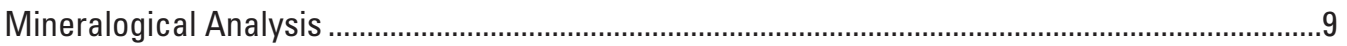

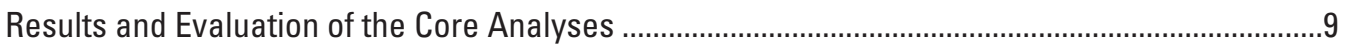

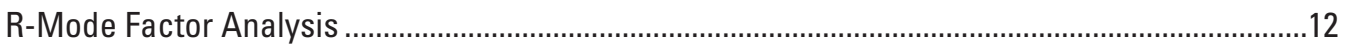

Distributions of Elements and Minerals in the Subsurface .......................................................16

Mainly Hypogene Sulfide-Related Elements and Minerals..................................................16

Mainly Lithology- and Alteration-Related Elements and Minerals ........................................34

Part B — Surface Geochemical Studies of Rock, Soil, and Vegetation.............................................57

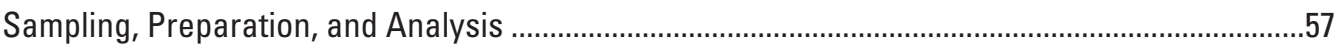

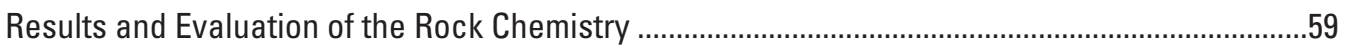

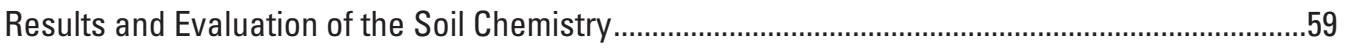

Results and Evaluation of the Vegetation Chemistry .................................................................5

Distributions of Selected Elements in Rock and Soil Samples ...................................................70

Distribution of Percent Ash and Selected Elements in Vegetation Samples.................................109

Applications of Geochemical and Mineralogical Analyses to Geologic Mapping, Mineral Deposit Genesis and Models, Distribution and Zoning of Elements and Minerals, Exploration for Mineral Deposits, and Environmental Investigations .......154

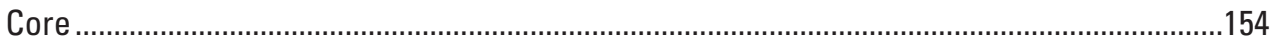

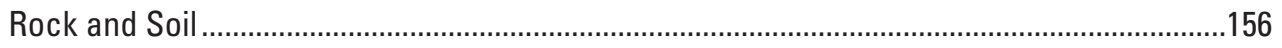

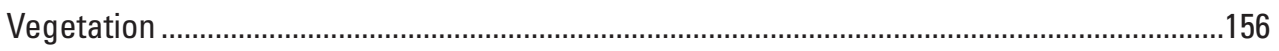

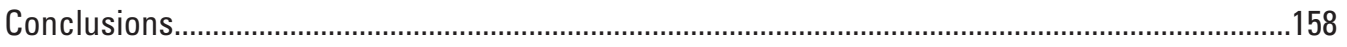

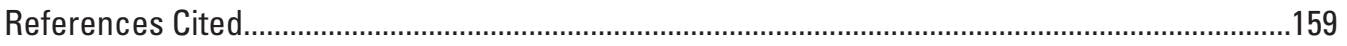

\section{Figures}

1. Map showing location of the study area, near Patagonia, Santa Cruz County, Arizona.

2. Geologic map of the study area showing locations of the geologic section shown in figure 3 and sites for samples of rock, soil, and plants

3. Geologic cross section showing locations of seven drill holes ......................................6

4. A, Photograph of exposures of altered Gringo Gulch Volcanics, which are correlated with the rhyolite tuff formation on top of Red Mountain. $B$, Photograph of Red Mountain as viewed from the south. $C$, Photograph of the study area as viewed from the west with Red Mountain in the background. $D$, Photograph of exposures of the altered andesite formation overlain with indurated Tertiary gravel containing extensive manganese oxide cement.

5-39. Cross sections of:

5. Distributions of copper, chalcopyrite, and chalcocite in core samples 13

6. Distribution of silver in core samples. 
7. Distribution of total sulfur in core samples ...........................................................19

8. Distributions of sulfate sulfur, anhydrite, and alunite in core samples ...................20

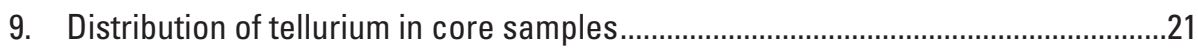

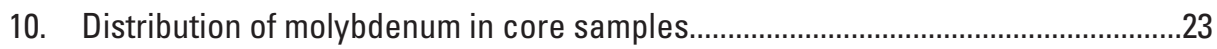

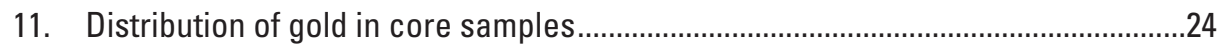

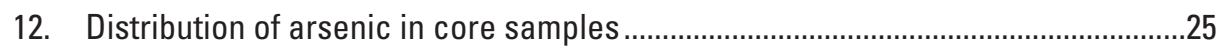

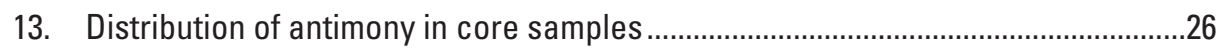

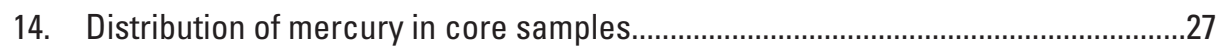

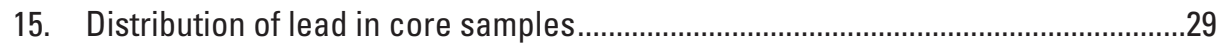

16. Distribution of zinc in core samples ..............................................................30

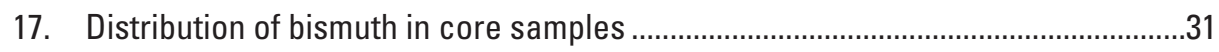

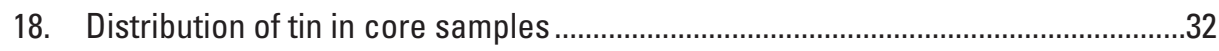

19. Distribution of tungsten in core samples..........................................................3

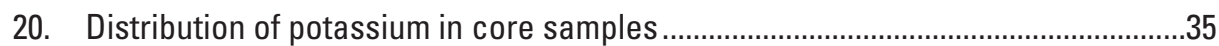

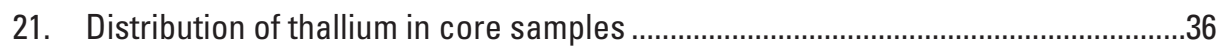

22. Distribution of orthoclase in core samples ........................................................

23. Distribution of kaolinite and other clay minerals in core samples...........................38

24. Distribution of pyrophyllite in core samples...........................................................39

25. Distributions of magnetite and biotite in core samples ..........................................40

26. Distribution of cobalt in core samples ................................................................42

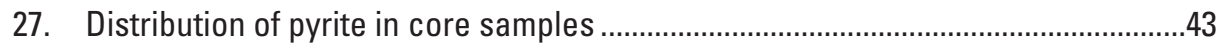

28. Distribution of hematite in core samples.............................................................4

29. Distributions of calcium and calcite in core samples .........................................45

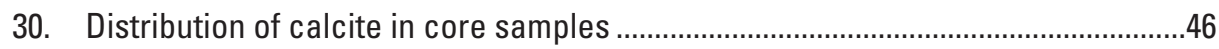

31. Distribution of sodium in core samples..............................................................47

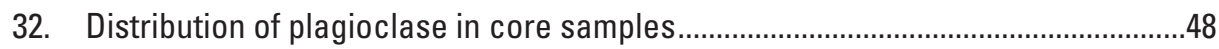

33. Distribution of manganese in core samples.....................................................

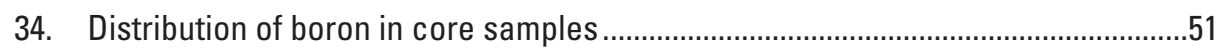

35. Distribution of uranium in core samples...........................................................52

36. Distribution of magnesium in core samples.........................................................

37. Distribution of chlorite in core samples...........................................................

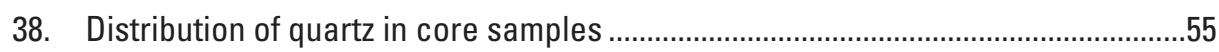

39. Distribution of muscovite (sericite) in core samples .................................................56

40. Photographs showing $A$, Mesquite (Prosopis juliflora) tree.

$B$, Oak (Quercus spp.) trees. C, Oneseed juniper (Juniperus monosperma) tree............58

41-119. Maps showing:

41. Sample locations, and the outer limit of intense, visible alteration in outcrops.....71

42. Distribution of copper in rock samples ...............................................................72

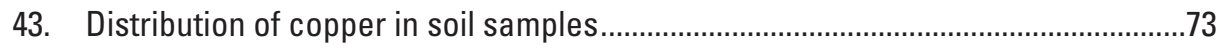

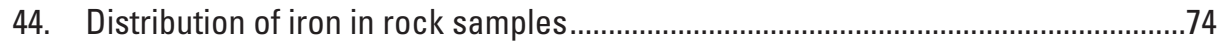

45. Distribution of iron in soil samples..........................................................................

46. Distribution of molybdenum in rock samples....................................................

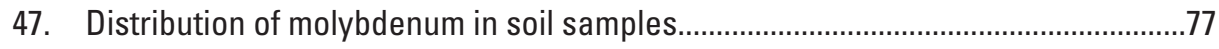

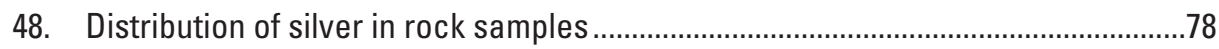

49. Distribution of silver in soil samples...................................................................79

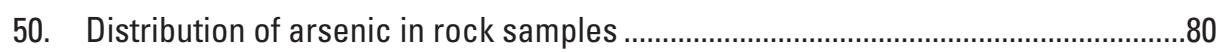




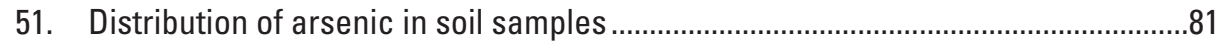

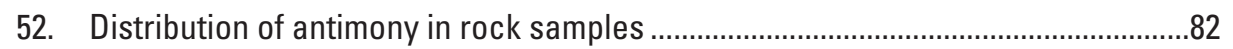

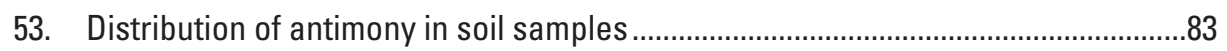

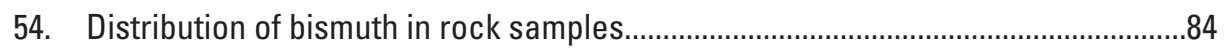

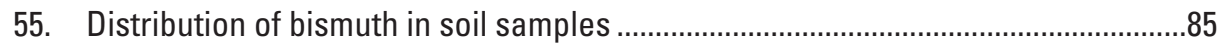

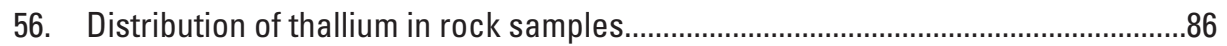

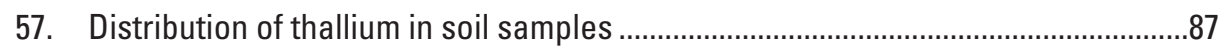

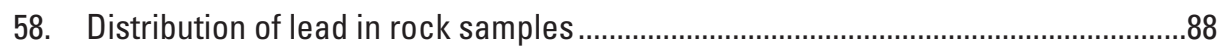

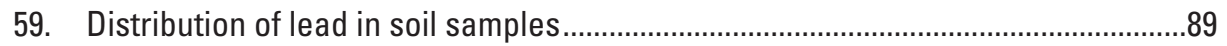

60. Distribution of tellurium in rock samples ..............................................................90

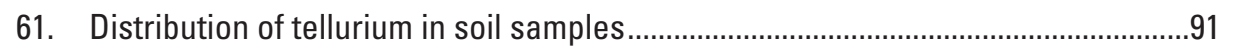

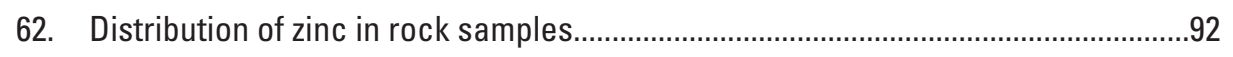

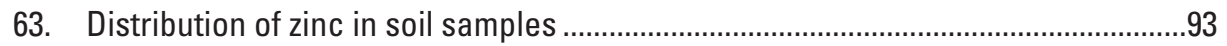

64. Distribution of cadmium in rock samples ………...............................................

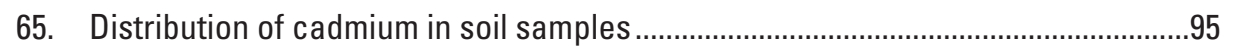

66. Distribution of cobalt in rock samples.............................................................

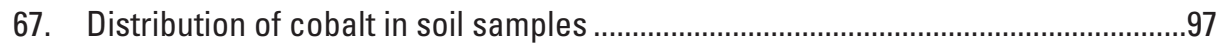

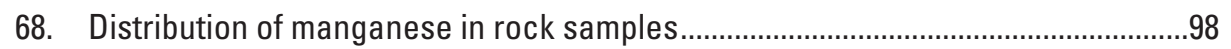

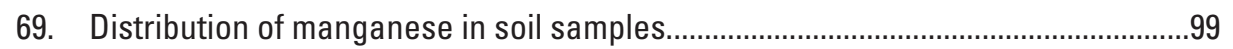

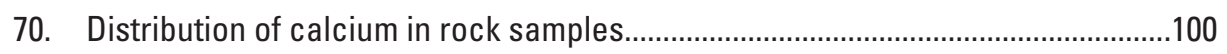

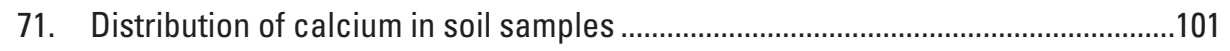

72. Distribution of magnesium in rock samples .........................................................102

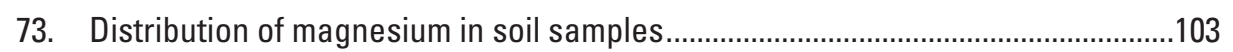

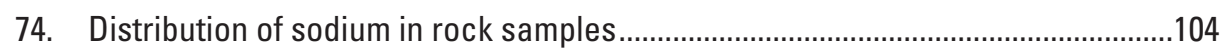

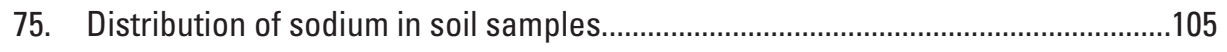

76. Distribution of potassium in rock samples ……………........................................106

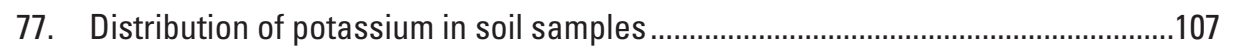

78. Distribution of percent ash in mesquite samples...............................................110

79. Distribution of percent ash in oak samples............................................................111

80. Distribution of percent ash in juniper samples.....................................................112

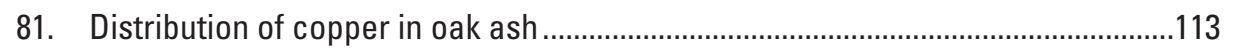

82. Distribution of copper in mesquite ash .................................................................114

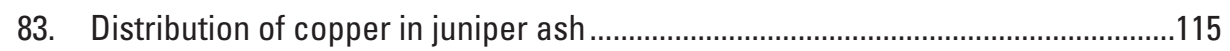

84. Distribution of molybdenum in mesquite ash.....................................................116

85. Distribution of molybdenum in oak ash..............................................................117

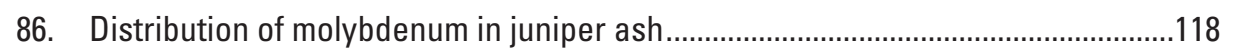

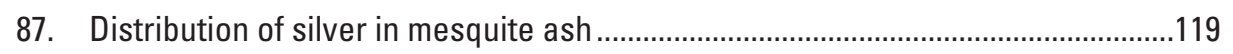

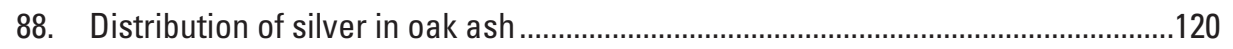

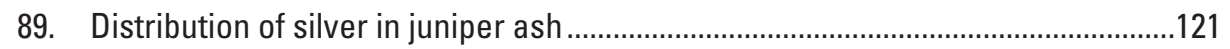

90. Distribution of arsenic in mesquite ash ..........................................................123

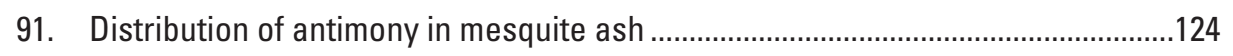

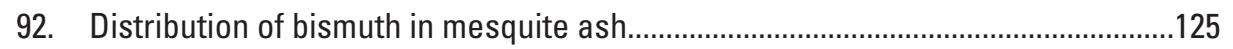

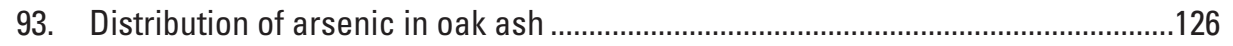

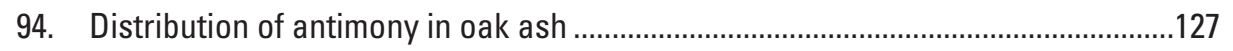

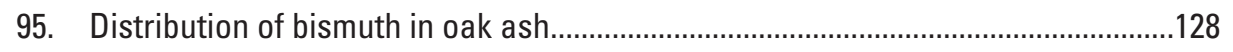


96. Distribution of arsenic in juniper ash ...............................................................129

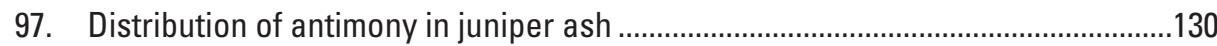

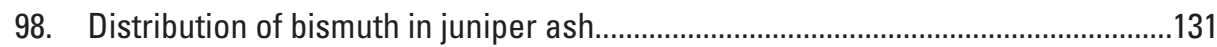

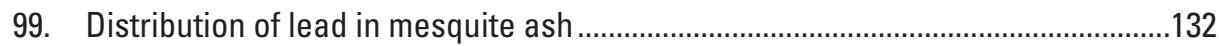

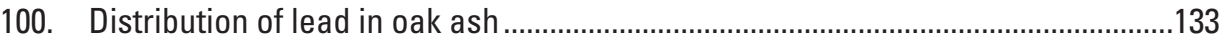

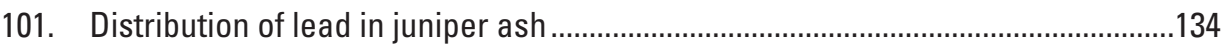

102. Distribution of zinc in mesquite ash....................................................................135

103. Distribution of cadmium in mesquite ash ............................................................136

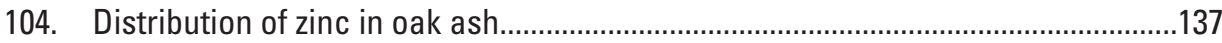

105. Distribution of cadmium in oak ash ...................................................................138

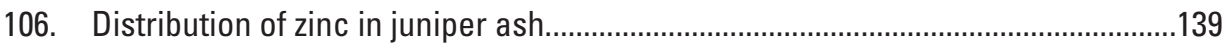

107. Distribution of cadmium in juniper ash ............................................................140

108. Distribution of selenium in mesquite ash........................................................142

109. Distribution of selenium in oak ash....................................................................143

110. Distribution of selenium in juniper ash..............................................................144

111. Distribution of sodium in mesquite ash............................................................. 145

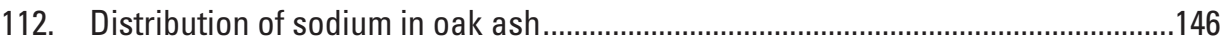

113. Distribution of sodium in juniper ash.................................................................147

114. Distribution of manganese in mesquite ash..........................................................148

115. Distribution of manganese in oak ash..................................................................149

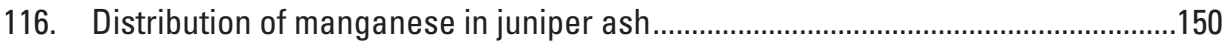

117. Distribution of magnesium in mesquite ash ........................................................151

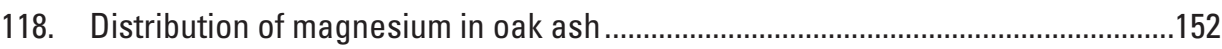

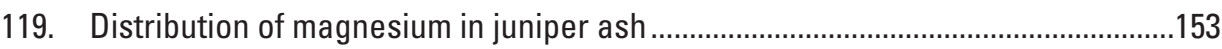

\section{Tables}

1. d-Spacings and diffraction peaks used to determine peak heights used to show the relative abundances of minerals in drill core samples, Red Mountain, Arizona.........9

2. Summary of chemical data for 818 drill core samples and comparative background data, Red Mountain, Arizona, and vicinity ....................................................................10

3. Factor loading values for core samples from the hypogene and supergene zones, Red Mountain, Arizona .

4. Summary of chemical data for 54 elements in 122 samples of rock outcrop and comparative background data, Red Mountain, Arizona

5. Summary of chemical data for 55 elements in 119 soil samples and comparative background data, Red Mountain, Arizona

6. Summary of chemical data for ash and 66 elements in 57 mesquite ash samples, Red Mountain, Arizona ................................................................................................64

7. Summary of chemical data for ash and 66 elements in 108 oak ash samples, Red Mountain, Arizona ...

8. Summary of chemical data for ash and 66 elements in 68 juniper ash samples, Red Mountain, Arizona . 


\section{Conversion Factors}

International System of Units to U.S. customary units

\begin{tabular}{llc}
\hline \multicolumn{1}{c}{ Multiply } & By & To obtain \\
\hline millimeter $(\mathrm{mm})$ & Length & inch (in.) \\
meter $(\mathrm{m})$ & 0.03937 & foot $(\mathrm{ft})$ \\
kilometer $(\mathrm{km})$ & 3.281 & mile (mi) \\
\hline
\end{tabular}

Temperature in degrees Celsius $\left({ }^{\circ} \mathrm{C}\right)$ may be converted to degrees Fahrenheit $\left({ }^{\circ} \mathrm{F}\right)$ as ${ }^{\circ} \mathrm{F}=\left(1.8 \times{ }^{\circ} \mathrm{C}\right)+32$.

\section{Abbreviations}

$\begin{array}{ll}\mathrm{AAS} & \text { atomic-absorption spectrometry } \\ 2 \theta & \text { two theta } \\ \mathrm{Ag} & \text { silver } \\ \mathrm{Al} & \text { aluminum } \\ \mathrm{Ar}-\mathrm{Ar} & \text { argon-argon } \\ \mathrm{As} & \text { arsenic } \\ \mathrm{Au} & \text { gold } \\ \mathrm{B} & \text { boron } \\ \mathrm{Ba} & \text { barium } \\ \mathrm{Be} & \text { beryllium } \\ \mathrm{Bi} & \text { bismuth } \\ \mathrm{Br} & \text { bromine } \\ \mathrm{Ca} & \text { calcium } \\ \mathrm{Cd} & \text { cadmium } \\ \mathrm{Ce} & \text { cerium } \\ \mathrm{Co} & \text { cobalt } \\ \mathrm{Cr} & \text { chromium } \\ \mathrm{Cs} & \text { cesium } \\ \mathrm{Cu} & \text { copper } \\ \mathrm{Cu}-\mathrm{Mo} & \text { copper-molybdenum } \\ \mathrm{d}-\mathrm{spacing} & \text { d is the distance between the parallel reflecting planes in a crystal as } \\ \mathrm{Gd} & \text { determined by XRD } \\ \text { gadolinium }\end{array}$




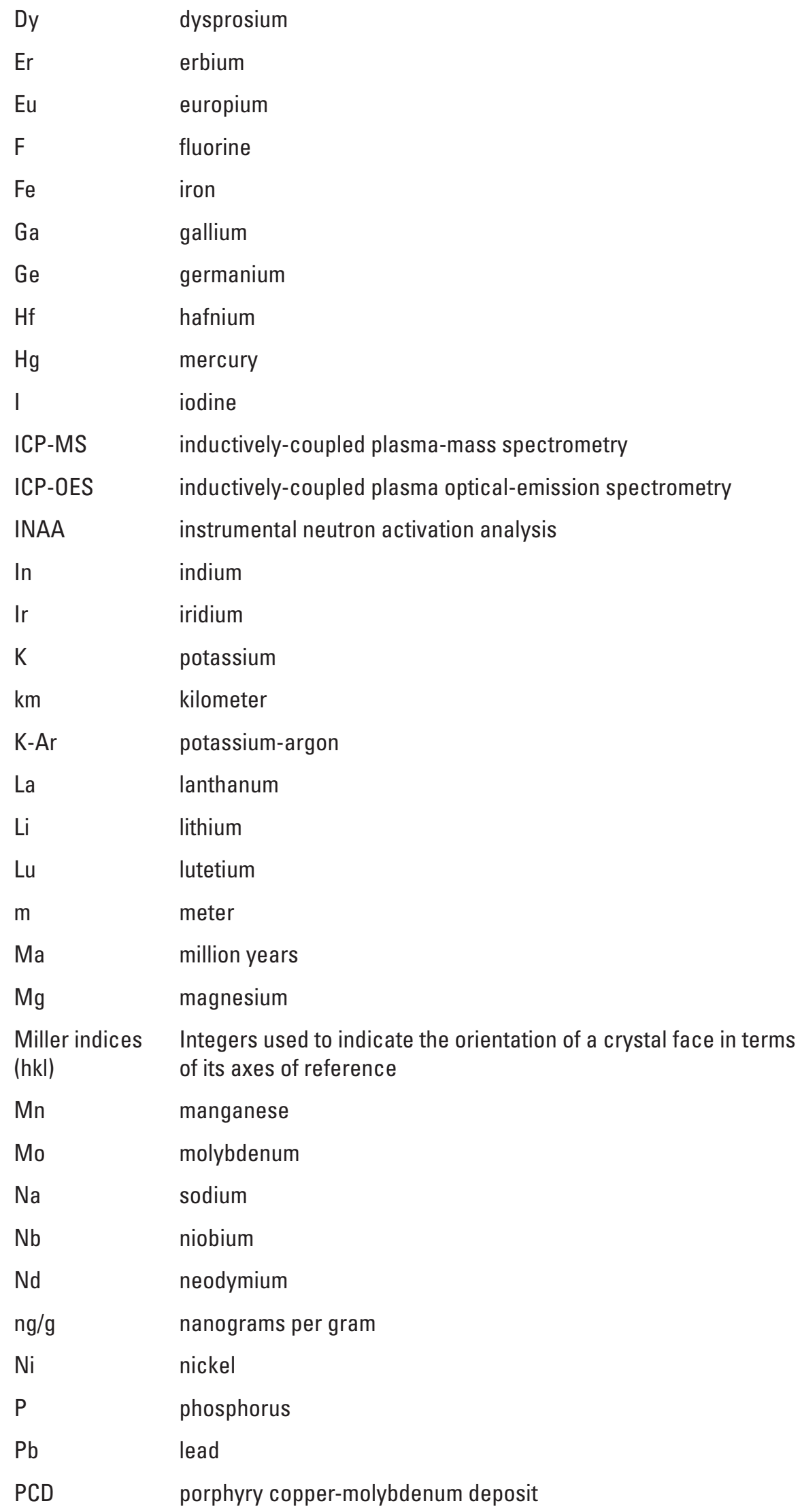




\begin{tabular}{|c|c|}
\hline ppb & parts per billion \\
\hline ppm & parts per million \\
\hline $\mathrm{Rb}$ & rubidium \\
\hline $\operatorname{Re}$ & rhenium \\
\hline S & sulfur \\
\hline $\mathrm{Sb}$ & antimony \\
\hline Sc & scandium \\
\hline Se & selenium \\
\hline $\mathrm{Si}$ & silicon \\
\hline Sm & samarium \\
\hline Sn & tin \\
\hline $\mathrm{Sr}$ & strontium \\
\hline Ta & tantalum \\
\hline $\mathrm{Tb}$ & terbium \\
\hline Te & tellurium \\
\hline Th & thorium \\
\hline $\mathrm{Ti}$ & titanium \\
\hline $\mathrm{TI}$ & thallium \\
\hline $\mathrm{Tm}$ & thulium \\
\hline U & uranium \\
\hline $\mathrm{U}-\mathrm{Pb}$ & uranium-lead \\
\hline USGS & U.S. Geological Survey \\
\hline V & vanadium \\
\hline W & tungsten \\
\hline XRD & X-ray diffraction \\
\hline Y & yttrium \\
\hline $\mathrm{Yb}$ & ytterbium \\
\hline $\mathrm{Zn}$ & zinc \\
\hline $\mathrm{Zr}$ & zirconium \\
\hline
\end{tabular}

\section{Datum}

Vertical coordinate information is referenced to the North American Vertical Datum of 1988 (NAVD 88).

Horizontal coordinate information is referenced to the North American Datum of 1927 (NAD27). 


\title{
Geochemical and Mineralogical Study of the Red Mountain Porphyry Copper-Molybdenum Deposit and Vicinity, Santa Cruz County, Arizona
}

\author{
By Maurice A. Chaffee
}

\section{Abstract}

The Red Mountain porphyry copper-molybdenum deposit (Cu-Mo deposit or PCD) is located in the northern part of the Patagonia Mountains, Santa Cruz County, Arizona. Extensive core drilling has delineated a large, deep-seated, structurally intact mineral system that extends from the present surface to depths of more than 1,765 meters. This system is hosted in a thick complex of predominantly felsic to andesitic volcanic rocks of the Cretaceous Period. This complex was intruded by scattered bodies of the Tertiary Period that are predominantly quartz monzonite porphyry; no major associated source intrusion has yet been found at depth.

A total of 818 samples of core were analyzed for as many as 44 elements. The abundances and distributions at depth of at least 17 of these elements (silver [Ag], arsenic [As], gold $[\mathrm{Au}]$, boron $[\mathrm{B}]$, bismuth $[\mathrm{Bi}]$, copper $[\mathrm{Cu}]$, mercury $[\mathrm{Hg}]$, potassium $[\mathrm{K}]$, molybdenum $[\mathrm{Mo}]$, lead $[\mathrm{Pb}]$, sulfur $[\mathrm{S}]$, antimony $[\mathrm{Sb}]$, tin $[\mathrm{Sn}]$, tellurium [Te], thallium [Tl], tungsten $[\mathrm{W}]$, and zinc $[\mathrm{Zn}])$ are related mostly to events that generated the Red Mountain system. Many of these same samples were also analyzed by X-ray diffraction for a suite of minerals. The multielement and mineralogical analyses of the core samples provide important information about the concentrations, associations, and distributions of select elements and minerals, including zoning patterns that may not be apparent from visual examination of core samples. The distributions of selected elements and minerals in these samples reveal an unusually complete mineral system that extends from a typical PCD with potassic alteration at depth to peripheral zones of phyllic and advanced argillic alteration as well as a copper-rich supergene enriched zone and the remnants of a leached cap.

R-mode factor analysis was run with 34 elements for a set of samples from the deep part of the hypogene Cu-Mo deposit and another set from the part of the supergene zone with the highest copper enrichment. For the hypogene zone dataset, five factors are related to the PCD: (1) Ag, $\mathrm{Cu}, \mathrm{Mo}, \mathrm{S}$, and Te; (2) As, B, Hg, and Sb; (3) Au and sodium (Na); (4) manganese $(\mathrm{Mn}), \mathrm{Pb}$, and $\mathrm{Zn}$; and (5) $\mathrm{K}$ and $\mathrm{Tl}$. For the supergene dataset, the deposit-related factors include (1) $\mathrm{Cu}, \mathrm{Mo}, \mathrm{S}$, and Te;
(2) $\mathrm{Ag}, \mathrm{As}, \mathrm{Hg}, \mathrm{Pb}, \mathrm{Sb}$, and $\mathrm{Tl}$; (3) $\mathrm{Au}$ and $\mathrm{Na}$; and (4) $\mathrm{K}$ and rubidium $(\mathrm{Rb})$. The changes in element associations between the two datasets indicate that some of these new associations are a result of formation of several suites of hypogene minerals in the deep part of the deposit and different hypogene mineral suites in the peripheral part of the deposit. Some changes may be because of the effects of supergene processes.

Zones containing deposit-related elements and minerals common to many PCDs are present at Red Mountain. These zones include a crude, inverted cup-shaped shell containing anomalous copper accompanied by high concentrations of $\mathrm{Ag}, \mathrm{Au}, \mathrm{K}, \mathrm{Mo}$, total $\mathrm{S}$, sulfate $\mathrm{S}, \mathrm{Sb}, \mathrm{Te}$, and $\mathrm{Tl}$, as well as local concentrations of As, B, Hg, Pb, and Zn. Hydrothermal minerals spatially associated with the deep hypogene $\mathrm{Cu}-\mathrm{Mo}$ deposit include chalcopyrite, molybdenite, pyrite, plagioclase, orthoclase, biotite, magnetite, calcite, quartz, and anhydrite.

Many of the hydrothermally deposited elements that are spatially related to the deposit are also concentrated in zones above the deep part of the deposit, including $\mathrm{Ag}, \mathrm{As}, \mathrm{K}, \mathrm{Pb}$, $\mathrm{Sb}, \mathrm{Te}, \mathrm{Tl}$, and $\mathrm{Zn}$. These elements are concentrated either (1) in generally wide, flat zones present in the upper part of the system or (2) in crudely arcuate peripheral zones found mainly in the middle part of the system and surrounding the deep part of the deposit. Near-surface, restricted hypogene anomalies are present for bismuth, mercury, tin, and tungsten.

The upper part of the deposit has been subjected to supergene enrichment and weathering. Deposit-related elements that remain anomalous in this area include $\mathrm{Ag}, \mathrm{As}, \mathrm{Au}, \mathrm{B}, \mathrm{Bi}$, cobalt $(\mathrm{Co}), \mathrm{Cu}$, $\mathrm{Hg}, \mathrm{Mo}, \mathrm{Pb}, \mathrm{S}, \mathrm{Sb}, \mathrm{Sn}, \mathrm{Te}, \mathrm{Tl}$, uranium (U), and $\mathrm{W}$. These positive concentrations indicate that, with the exception of copper and possibly mercury and uranium, these elements had relatively low chemical mobilities in the supergene enrichment and later weathering environments at Red Mountain. Most may have been deposited during one or more hypogene events and then redistributed locally during later events. Zinc is the only deposit-related element that has clearly been depleted as a result of supergene and (or) weathering events. Minerals that are common in the unweathered upper part of the system include chalcocite, pyrite, quartz, sericite, alunite, and pyrophyllite, as well as less common covellite, enargite, tennantite, tourmaline, barite, anglesite, and other sulfide or sulfate minerals. 
Subsequent to formation of the Red Mountain $\mathrm{Cu}-\mathrm{Mo}$ deposit and supergene enrichment, chemical weathering produced an area of pervasive hematite and other iron oxides in the near-surface part of the deposit to form a leached cap. These iron-rich minerals formed primarily as a result of the oxidation of pyrite. This event was accompanied by losses of cobalt, mercury, magnesium, and zinc, as well as destruction of sericite, plagioclase, pyrite, clay minerals, and pyrophyllite.

A total of 122 rock samples, 119 soil samples, and samples of three plant species (57 mesquite, 108 oak, and 68 juniper) were collected over and around Red Mountain. For the rock and soil samples, the distributions of anomalous $\mathrm{Ag}, \mathrm{As}, \mathrm{Bi}, \mathrm{Cu}, \mathrm{Fe}$, $\mathrm{Mo}, \mathrm{Pb}, \mathrm{Sb}, \mathrm{Te}$, and $\mathrm{Tl}$ best delineated the exposed part of the deposit. The highest concentrations of many of these elements are centered on one or both of two main areas with exposures of quartz monzonite porphyry. The high concentrations of arsenic in the deposit area (as much as 390 parts per million (ppm) in rock and 1,500 ppm in soil) and of lead (as much as 2,370 ppm in rock and 1,490 ppm in soil) are particularly noteworthy.
The concentrations of various elements in the plant ash vary widely among the three species and are species dependent. Many of the deposit-related elements are either nonessential for plant growth or are considered toxic at certain concentration ranges. In spite of this, the distributions of potentially toxic $\mathrm{Ag}$, $\mathrm{As}, \mathrm{Bi}, \mathrm{Cd}, \mathrm{Cu}, \mathrm{Mo}, \mathrm{Pb}, \mathrm{Sb}$, selenium ( $\mathrm{Se}$ ), and $\mathrm{Zn}$ produce deposit-related anomalies for one or more of the three species.

Vegetation sampling offered no advantage over rock or soil sampling as an exploration tool. From an environmental standpoint, however, the plant analyses provide baseline data for both essential and nonessential elements that might be useful, for example, for selecting native plant species for revegetating mine waste areas.

The exposed part of the Red Mountain deposit has not been greatly disturbed as a result of mining and other activities. However, some of the rock, soil, and plant samples that were collected near the Harshaw Creek and Alum Gulch drainages, which are peripheral to Red Mountain, are also anomalous for various deposit-related elements. These anomalies are probably the result of dispersion of stream sediments contaminated with material from past mining.
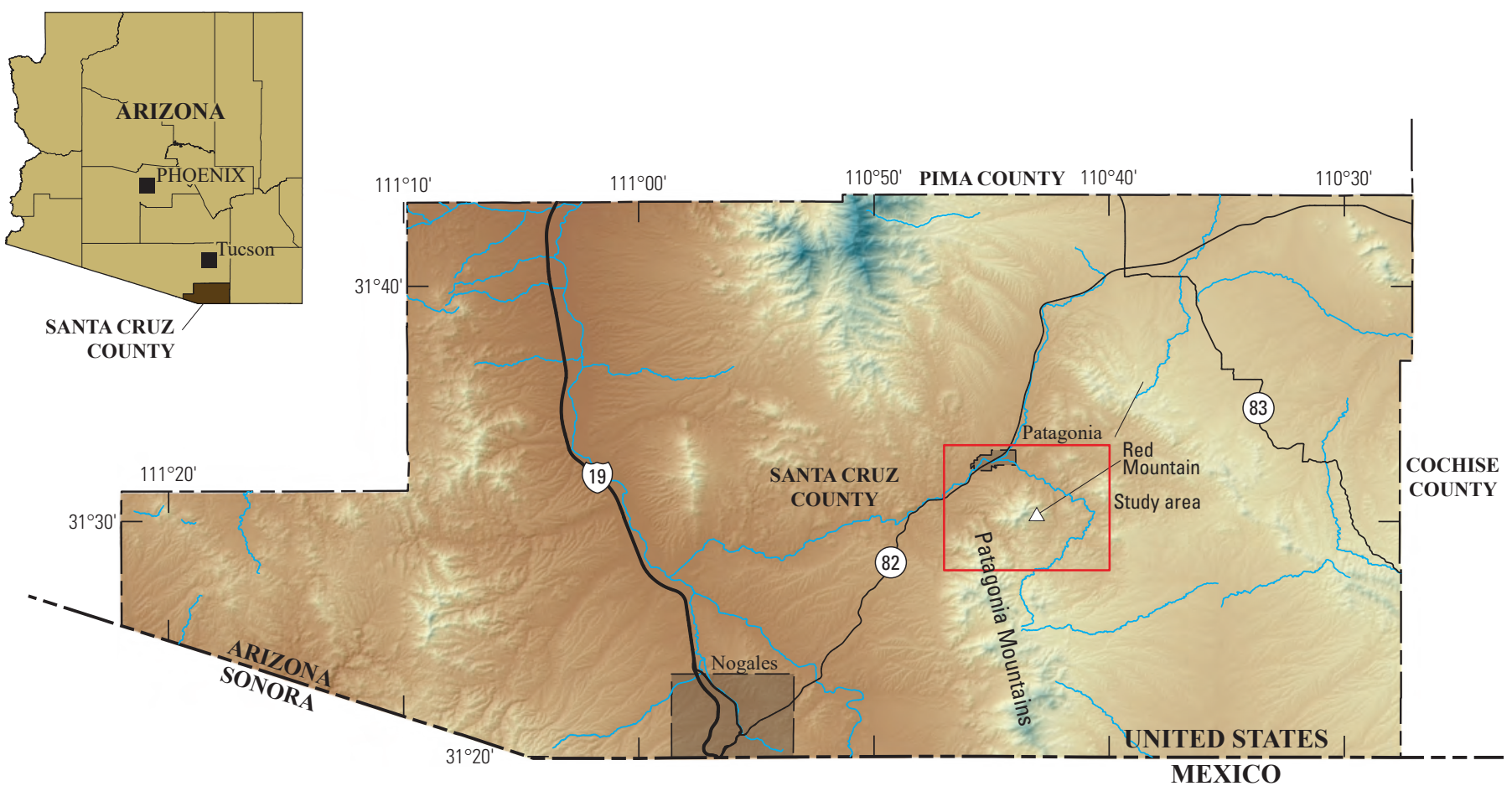

Base from U.S. Geological Survey digital data, The National Map, 2018 3D Elevation Program, 1/3 arc-second resolution Geographic projection, decimal degrees North American Datum of 1983

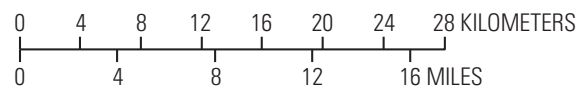

Figure 1. Location of the study area, near Patagonia, Santa Cruz County, Arizona. 


\section{Introduction}

Extensive deep core drilling delineated a major, deep-seated, structurally intact porphyry copper-molybdenum deposit (Cu-Mo deposit or PCD) at Red Mountain, in the northern part of the Patagonia Mountains, Santa Cruz County, Arizona (fig. 1). This deposit is exposed in surface outcrops and continues downward to depths of more than 1,765 meters (m) (Corn, 1975; Quinlan, 1981, 1986; Lecumberri-Sanchez and others, 2013). The relatively complete vertical range, with all its zoning features, emphasizes the significance of studying this deposit. Additionally, the deposit area is relatively undisturbed by mining and other anthropogenic activities.

Chemical and mineralogical zoning as well as mineralization- and alteration-related zoning typical of many PCDs are present at Red Mountain. These include potassic, phyllic, and advanced argillic zones, as well as a zone of supergene enrichment and the remnant of a leached cap.

Because PCDs are the most important source of copper worldwide, many articles have been published describing this deposit type. Most articles emphasize the geology, petrography, and genesis of one or more deposits and commonly describe some of the mineral zoning and alteration assemblages on the surface and (or) at depth, tonnage of ore, ages of the various events that formed the deposit, as well as many other parameters. Many of the common and less common features in porphyry ore deposits have been described in detail (Guilbert and Lowell, 1974; Lowell and Guilbert, 1970). However, discussion of the concentrations and distributions of specific elements in any of these reports is often limited. The elements described in published reports are usually those of economic interest, mainly $\mathrm{Cu}, \mathrm{Mo}$, silver (Ag), gold $(\mathrm{Au})$, and sometimes lead $(\mathrm{Pb})$ and zinc (Zn) (for example, Candela and Piccoli, 2005; Gustafson and Hunt, 1975; Gustafson and Quiroga G., 1995; Mason and MacDonald, 1978; Seedorff and others, 2005; Sillitoe and Perelló, 2005; Titley and Anthony, 1989; and articles in Brown, 1976; Pierce and Bolm, 1995; Schroeter, 1995; Titley, 1982; Titley and Hicks, 1966).

Some published articles include tables and (or) discussion of analytical data that mainly relate to specific rock types associated with a PCD, but these articles typically do not illustrate the distribution of the elements included in the rock analyses (for example, Atapour and Aftabi, 2007; Chang and others, 2011; Cox and others, 1995; Dupont and others, 2002; Lang and Titley, 1998; McLemore and others, 1999; Richards and others, 2001; Rieger and others, 2010; Teal and Benavides, 2010; Ulrich and Heinrich, 2002). However, many elements may be associated with formation of a given PCD, and their concentrations and distributions can provide additional useful information on the genesis and characterization of that deposit.

Chemical concentrations and (or) distributions have been described for several PCDs (for example, Carson and others, 1976; Chaffee, 1976a; Chaffee and Hessin, 1971; Cox, 1985;
Gott and McCarthy, 1966; Govett, 1983; Gunton and Nichol, 1975; Jambor, 1974; Jerome, 1966; Osatenko and Jones, 1976). Most of these reports are limited to a few elements and most do not include contours of the chemical and (or) mineral zoning that may be present. Earlier investigations of chemical zoning present in the Kalamazoo, Arizona, PCD (Chaffee, 1976b, 1982) were more limited in scope than the one presented here, but did reveal several chemical zones related to that deposit. A more recent study of the geology and geochemistry of the Myszków porphyry copper-molybdenum-tungsten deposit in southern Poland includes detailed summaries of concentrations for 42 elements as well as the distributions of 15 of these elements in cross sections (Chaffee and others, 2001; Lasoń, 2001; Markowiak and Habryn, 2001).

The present study identifies and evaluates both subsurface and surface data associated with the Red Mountain PCD. The subsurface data are based on core analyses and include concentrations and distributions of elements and minerals, some of which are related to the mineral deposit and some of which are more closely associated with the host lithologic units. Element concentrations and distributions on the surface are based on analyses of rock, soil, and vegetation samples.

This report is divided into two parts. The focus of Part A is the concentrations, associations, and distributions of a large suite of elements and some common minerals in core samples collected from a fence of seven drill holes and an additional hole south of the fence, all of which penetrated from the surface to depths of as much as $1,765 \mathrm{~m}$. Many of the elements determined for this investigation are not often included in published reports of mineral deposits, yet information on them should be helpful in understanding the formation of the Red Mountain system and may be useful in locating blind mineralized areas within other systems. The distributions also reflect the behavior and relative mobility of some of the elements and minerals.

Part B of this report describes the concentrations and distributions of elements in rock, soil, and vegetation samples collected at the surface in the vicinity of the Red Mountain system. These samples provide geochemical information for selected elements, resulting only from natural weathering and erosion at the top of this deposit. Because many of the elements may have adverse environmental effects, baseline concentrations of these elements can provide the basis for comparative studies. The information described in this report may also be useful for adding new details to PCD models such as that published by John and others (2010). The analytical data used to generate the tables of concentration ranges and other statistical information, and also the distributions of elements and minerals, are included for the benefit of persons interested in doing further studies beyond the scope of this report. It is hoped that the statistical data, as well as the element and mineral distributions shown on the cross sections and element distributions shown on the maps, will provide new baseline information for a variety of sample media collected in and near a relatively complete and undisturbed PCD. 


\section{Location and Geologic Setting}

The study area is located in the semiarid environment of southern Arizona, at the northern end of the Patagonia Mountains, about 80 kilometers (km) southeast of Tucson (fig. 1). The region is part of an aligned structural zone of Laramide intrusions and PCDs that extends from the Silver Bell deposit northwest of Tucson to the La Caridad deposit in Sonora, Mexico (John and others, 2010). The study area is one of moderate relief, with elevations ranging from about $1,940 \mathrm{~m}$ at the top of Red Mountain to about $1,235 \mathrm{~m}$ in the vicinity of Patagonia, Arizona, about $3 \mathrm{~km}$ northwest of Red Mountain. This area is centered on Red Mountain and is bounded on the east and south by the Harshaw Creek drainage, on the west by the Alum Gulch drainage, and on the north by the Patagonia fault (fig. 2).

The geology of Red Mountain and the surrounding areas in the Patagonia Mountains has been described by Drewes (1971a, 1971b, 1972), Schrader (1915), and Simons (1972, 1974). Several geologic studies discussing the Red Mountain porphyry system in some detail have also been published (Bodnar and Beane, 1980; Corn, 1975; Kistner, 1984; Lecumberri-Sanchez and others, 2013; Quinlan, 1981, 1986; Vikre and others, 2014). The Sunnyside PCD, which is nearby and geologically similar to the Red Mountain deposit, has been described by Graybeal (1996). Only limited geologic and petrographic information is included in this report as these topics were not the focus of this investigation.

Figure 2 shows the surface geology of the study area, which is generalized principally from the maps of Drewes (1971a, 1971b, 1972, 1996), Quinlan (1981, 1986), and Simons $(1972,1974)$. The oldest rocks in the area (J-Yh) are from the Mesoproterozoic Era to the Jurassic Period and crop out west of Red Mountain (Drewes, 1996). Formations of chiefly volcanic and plutonic rocks that range in age from Triassic to Tertiary ( $\mathrm{km}, \mathrm{J}-\mathrm{ki}, \mathrm{Kv}$, and TKv) crop out southwest of Red Mountain. A thick sequence of Cretaceous- to Tertiary-aged volcanic rocks, which includes both an extensive andesite formation (Ka) and a superjacent rhyolite tuff formation (TKr), host the Red Mountain PCD. These two formations are exposed throughout much of the study area. Indurated Tertiary terrace gravels are present in scattered localities, mainly north of the Patagonia fault, and Quaternary alluvium is present in many washes surrounding Red Mountain (QTag).

The subsurface geology through the Red Mountain PCD is illustrated on a roughly east-west section through the area of the system (fig. 3). The section is located on figure 2. The oldest formation present in the area of the section is known informally as the felsite-latite unit ( $\mathrm{Kv}$ on figures 2 and 3 ) and is at least $900 \mathrm{~m}$ thick. The base of this formation has not been found either on the surface or in drill core (Quinlan, 1986). This unit has been correlated with the Upper Cretaceous silicic volcanics of Simons (1974) and has been dated by the potassium-argon (K-Ar) method at about 72 million years (Ma) (Vikre and others, 2014). This felsite-latite unit consists of a succession of interlayered felsic volcanic conglomerates, breccias, tuffs, and possibly flows, together with andesite sills or flows near the top of the unit. Latite dikes and sills are present locally.

The felsite-latite unit is overlain by the andesite unit ( $\mathrm{Ka}$ on figures 2 and 3), which is as much as 1,300 m thick (Quinlan, 1986). This formation, which is composed of mostly porphyritic andesite and trachyandesite flows and breccias that have been intruded by andesite sills and dikes, has been correlated with the Upper Cretaceous trachyandesite of Meadow Valley in Simons (1972). This unit has been dated by the K-Ar method at about 72-71 Ma (Vikre and others, 2014).

The rhyolite tuff unit (TKr on figures 2 and 3) overlies the andesite unit and caps Red Mountain. Quinlan (1986) states that this formation was probably at least $450 \mathrm{~m}$ thick, but because of erosion, the original thickness of this unit is unknown. This formation consists of a series of dacitic to rhyolitic tuffs, flows, and breccias called the "Volcanics of Red Mountain" by Drewes (1971a), and correlated by him with the Gringo Gulch Volcanics of the Paleocene (?). The textures in samples of the rhyolite tuff unit from core and outcrops from Red Mountain are similar to the textures of samples of the Gringo Gulch Volcanics that crop out along Arizona State Highway 82, west of Patagonia, Arizona (fig. 4A). This unit, which was originally thought to be Late Cretaceous to early Tertiary, is now suspected to be entirely from the Cretaceous Period. (If true, the TKr symbol used would be incorrect.) Although some of the dates for the two formations given in Vikre and others (2014) were deemed to be inconclusive, the uranium-lead (U-Pb) age dates from zircons indicate a common age of about 69-67 Ma for rocks from these two areas, which, if correct, means that this formation is Cretaceous and not Paleocene. The outcrop similarities, along with zircon dates, imply that the correlation of Drewes for these two formations is correct but his age estimate is incorrect. Although the three major volcanic units that host the Red Mountain PCD have been correlated to formations mapped outside of the study area, the informal names assigned to these three volcanic formations by Quinlan $(1981,1986)$ are used in this report.

The Red Mountain volcanic sequence has been intruded by irregularly shaped bodies that vary in composition from granodiorite to quartz monzonite and are commonly porphyritic. These intrusive bodies (Tqm, figs. 2 and 3 ) have been dated by the U-Pb method at about $62 \mathrm{Ma}$ and copper deposit-related biotite by the argon-argon (Ar-Ar) method at about $60 \mathrm{Ma}$ (Vikre and others, 2014). These intrusive bodies are probably apophyses of a stock thought to be present at depth but not identified by any of the deep drilling at Red Mountain (J.J. Quinlan, oral commun., 1987). The differences in ages determined for these intrusions and the copper-related alteration - about 62 million years compared to 60 million yearswould indicate that emplacement of the intrusive bodies is not associated with formation of the Red Mountain PCD. However, the close spatial association of the surface and subsurface locations of quartz monzonite porphyry and high concentrations of copper and other deposit-related elements, implies at least a probable temporal relation. 


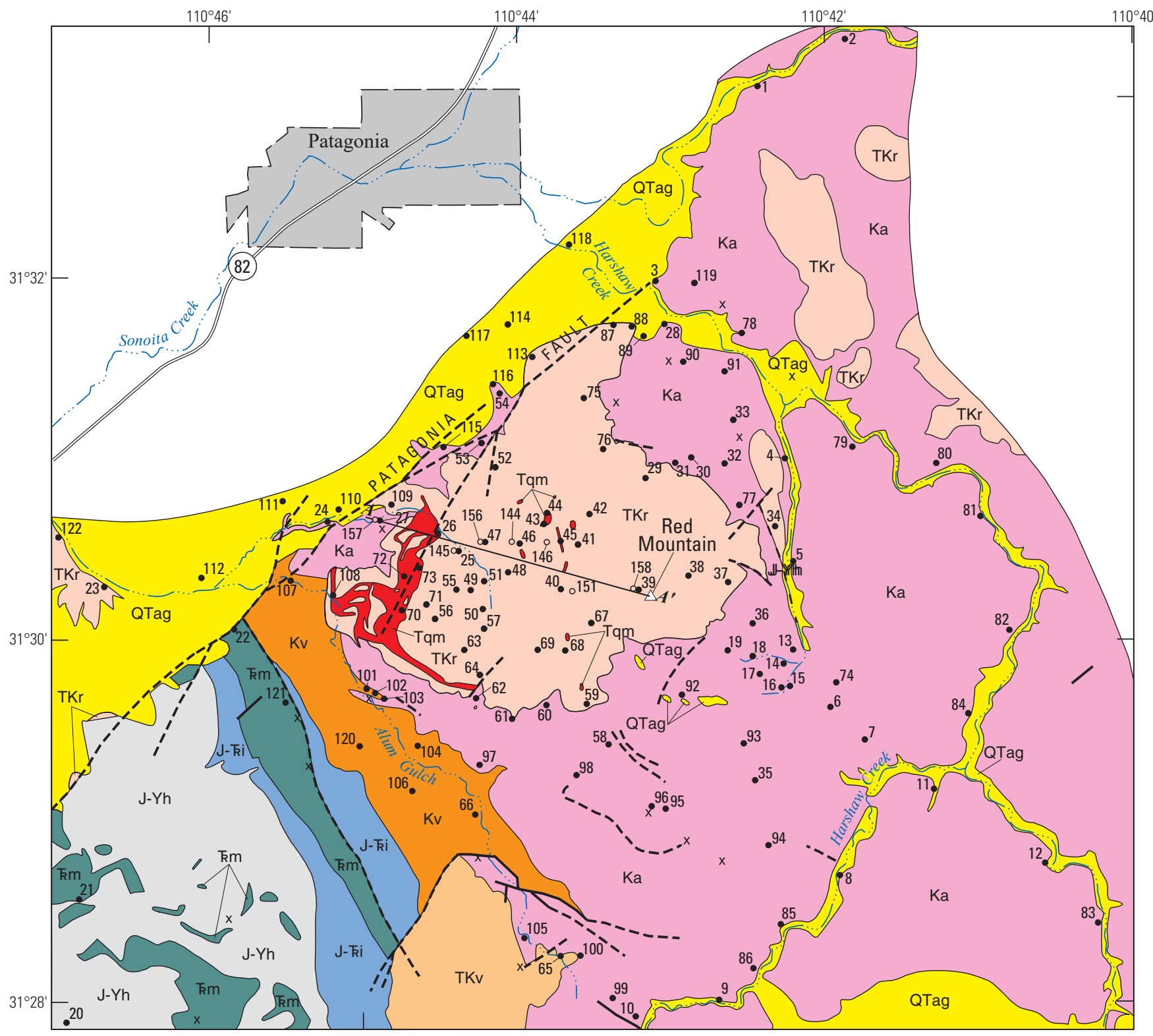

\section{EXPLANATION}

QTag Alluvium and terrace gravels, undivided

Quartz monzonite porphyryIntrusive rocks

TKr Volcanics of Red Mountain-Chiefly rhyolite tuff. Drewes, 1971a; 1972

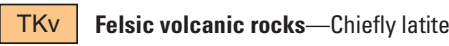

$\mathrm{Ka}$ Trachyandesite of Meadow ValleyChiefly andesite porphyry. Simons, 1972

Kv Silicic volcanics-Simons, 1974

$\mathrm{J}$ - $\mathrm{ki}$ Plutonic and volcanic rocks, undivided

Mount Wrightson Formation-Chiefly felsic volcanics

$\mathrm{J}-\mathrm{Yh}$ Hornblende-rich metamorphic and igneous rocks, undivided Contact-Locally concealed or inferred

Fault-Dashed where approximate or inferred

$A-A^{\prime}$ Line of section

82. Sample site and identifier

158。 Drill hole and identifier

$x \quad$ Mine or prospect site

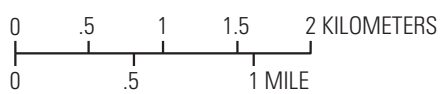

Base from U.S. Geological Survey digital data, 1:1,000,000, 2018 Geographic projection, decimal degrees

North American Datum of 1927

Geology modified from Drewes (1971a), Quinlan (1981, 1986), and Simons (1974).

Figure 2. Geologic map of the study area showing locations of the geologic section shown in figure 3 and sites for samples of rock, soil, and plants. 


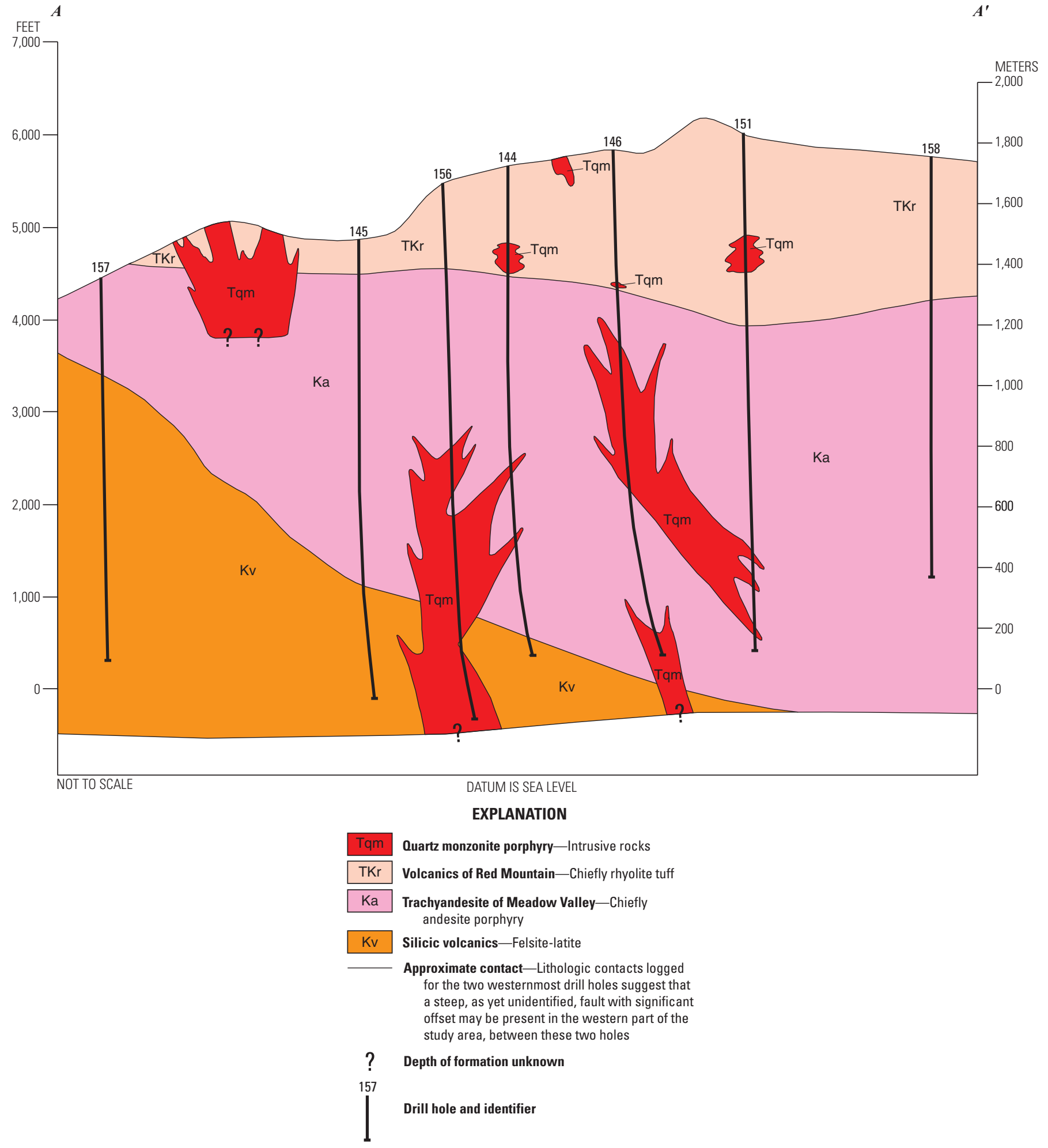

Figure 3. Geologic cross section showing locations of seven drill holes. 

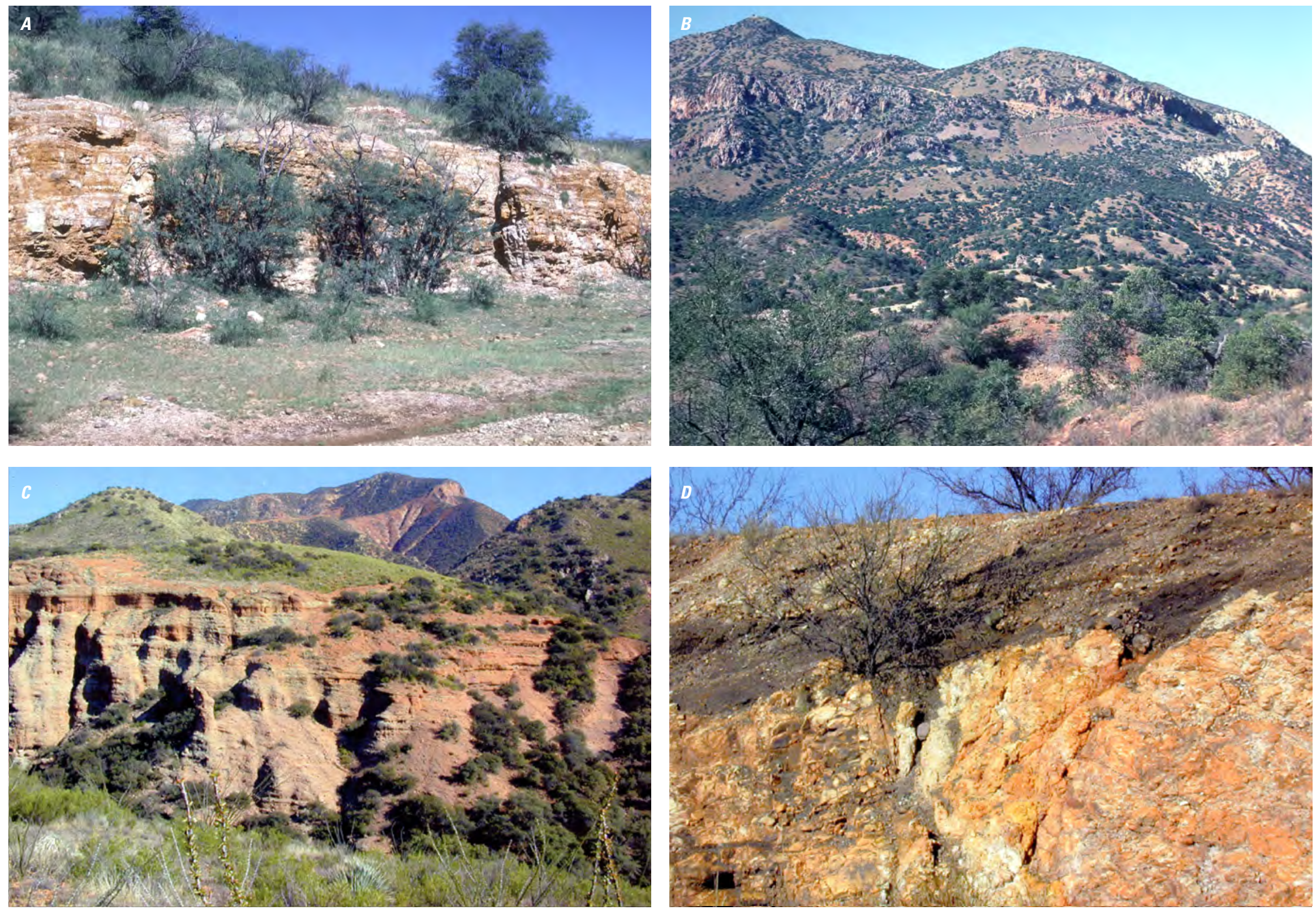

Figure 4. A, Photograph of exposures of altered Gringo Gulch Volcanics, which are correlated with the rhyolite tuff formation on top of Red Mountain. B, Photograph of Red Mountain as viewed from the south. The white cliffs near the top of the mountain are exposures of the altered rhyolite tuff formation. The andesite formation comprises all of the area below the cliffs. $C$, Photograph of the study area as viewed from the west with Red Mountain in the background. Exposures in the foreground are of Tertiary indurated terrace gravels. $D$, Photograph of exposures of the altered andesite formation overlain with indurated Tertiary gravel containing extensive manganese oxide cement. 
Lithologic contacts logged for the two westernmost drill holes (fig. 3) suggest that a steep, as yet unidentified, fault with significant offset may be present in the western part of the study area, between these two holes. The accompanying photographs illustrate typical exposures of the altered Gringo Gulch Volcanics (fig. 4A), the andesite and rhyolite tuff units (fig. $4 B$ ), the Tertiary terrace gravels (fig. $4 C$ ), and strongly altered andesite in the vicinity of Red Mountain (fig. 4D).

Most of the mineralization-alteration zones that are common to PCDs are present at Red Mountain. These zones include a relatively barren core surrounded by a major hypogene $\mathrm{Cu}-\mathrm{Mo}$ deposit that is present in the form of an inverted cup that projects as east and west limbs in a vertical section. The deposit spreads upward to the surface and is accompanied by welldeveloped potassic, phyllic, and advanced argillic alteration zones. A supergene enrichment zone, as well as a remnant of a leached cap, are also present. Boundaries between these zones are not easily defined and often overlap or are overprinted and modified by later events. Quinlan (1986) describes the distributions of major hydrothermal sulfide minerals and silicate alteration minerals in the Red Mountain system in some detail. His model shows two separate episodes, with early, barren, widespread potassic, phyllic, and advanced argillic zones overprinted by later, more restricted potassic, and phyllic zones associated with the hypogene $\mathrm{Cu}-\mathrm{Mo}$ deposit. However, the order and details of these two episodes have not been independently verified.

\section{Part A-Subsurface Geochemical and Mineralogical Studies of Core Sampling, Preparation, and Chemical Analysis of Core}

A total of 818 samples of core were collected from material provided by Kerr-McGee Corporation, including 708 samples from the fence of 7 drill holes shown in figure 3, and an additional 110 samples from a drill hole to the south of the fence. The location of the section for figure 3 is shown on the geologic map (fig. 2). Each sample was composited from typical material present in a 3-m run of core. The 3-m runs were spaced at approximately $15-\mathrm{m}$ intervals along the entire length of each drill hole. Care was exercised to sample only the principal lithology in each sample interval. Thin crosscutting bands of different rock types or highly mineralized veins or fractures were not included in the sample unless they were distributed through most of the 3-m interval. At the time the sampling was done, the core was relogged to supplement information given in the original logs. Cores from additional drill holes not discussed in this report were also examined visually to improve the overall understanding of the geology and mineral zoning.
The core samples were crushed and pulverized to about less than $(<) 0.074$ millimeter (mm) (minus 200 mesh). The samples were submitted for analysis in a random order. U.S. Geological Survey (USGS) internal standards and duplicate samples were included in each batch of 50 or less samples to monitor the quality of the analyses. The samples were collected and thus analyzed over the period from 1980 to 2000. During that time the analytical methods used at the USGS and at contract laboratories changed. Thus, not all samples were analyzed for the same suite of elements and (or) by the same methods.

The core samples were analyzed in the USGS Branch of Geochemistry laboratories in Denver for the elements $\mathrm{Ag}$, boron $(\mathrm{B})$, barium $(\mathrm{Ba})$, beryllium $(\mathrm{Be})$, bismuth $(\mathrm{Bi})$, calcium $(\mathrm{Ca})$, cadmium $(\mathrm{Cd})$, cobalt $(\mathrm{Co})$, chromium $(\mathrm{Cr})$, cesium $(\mathrm{Cs})$, copper $(\mathrm{Cu})$, iron $(\mathrm{Fe})$, lanthanum $(\mathrm{La})$, lithium $(\mathrm{Li})$, magnesium $(\mathrm{Mg})$, manganese $(\mathrm{Mn})$, molybdenum (Mo), niobium ( $\mathrm{Nb}$ ), nickel (Ni), $\mathrm{Pb}$, rubidium $(\mathrm{Rb})$, scandium $(\mathrm{Sc})$, tin $(\mathrm{Sn})$, strontium $(\mathrm{Sr})$, thorium (Th), titanium (Ti), vanadium $(\mathrm{V})$, tungsten $(\mathrm{W})$, yttrium (Y), and zirconium ( $\mathrm{Zr}$ ) by semiquantitative emission spectrography (Grimes and Marranzino, 1968; Motooka and Grimes, 1976). The core samples were also analyzed for other elements by the following methods: arsenic (As) by colorimetry (Welsch, 1979); Au by atomic-absorption spectrometry (AAS) (Meier, 1980); mercury (Hg) by cold-vapor atomic-absorption (Vaughn and McCarthy, 1964); potassium (K) and sodium (Na) by AAS (O'Leary and Meier, 1986); total sulfur (S) by a combustion/titrametric method (O'Leary, 1990); antimony (Sb) by AAS (Welsch and Chao, 1975); Te by AAS (Chao and others, 1978); thallium (Tl) by AAS (Hubert and Lakin, 1973); uranium (U) by a modification of the fluorometric method of Centanni and others (1956) as described by O'Leary and Meier (1986); and for Zn by AAS (Ward and others, 1969). A few samples were analyzed for fluorine (F) by ion-selective analysis (Hopkins, 1977); for Sn by AAS (Welsch and Chao, 1976); and for W by a visible spectrophotometric method (Welsch, 1983). All data analyzed for this study are available in a separate data release (Horton and others, 2020).

Prior to, and independent of, the USGS's study, the Kerr-McGee Corporation collected samples from mostly 3 -m runs of core in the same set of 7 drill holes and composited them to make 379 additional samples. These samples were crushed, pulverized, and analyzed for a variety of elements for the Kerr-McGee Corporation by a commercial laboratory. Sulfate analyses from the Kerr-McGee Corporation dataset (J.J. Quinlan, Kerr-McGee Corporation, written commun., 1980) have been used to illustrate the distribution of sulfate and sulfate-rich minerals. 


\section{Mineralogical Analysis}

During relogging, the core specimens were examined to visually identify the various rock types and minerals present and the locations of geologic contacts. Selected samples were analyzed by X-ray diffraction (XRD) to identify some common minerals present in pulverized sample material.

The relations of the most common hypogene deposit-related minerals, as determined from grain boundaries and crosscutting veins, reveal a complex history for the Red Mountain system. It is beyond the scope of this report to describe in detail all of these relations. Only the most general and widespread mineralogical features are discussed.

Of the 818 core samples, 245 from the seven holes on the section were prepared and analyzed by XRD to identify selected hydrothermal- and host-rock-related minerals and their relative concentrations. Separate aliquots of the crushed core were first ground in an agate mortar to $<0.062 \mathrm{~mm}$ (about minus $250 \mathrm{mesh}$ ). Approximately equal volumes of the resulting powders were mounted on glass slides and analyzed by XRD using a Phillips XRG-3000 generator configured with a copper lamp and nickel filter and run at 40 kilovolts and 26 milliamperes. The samples were scanned over a range of 4 to $60^{\circ}$ two theta $(2 \Theta)$ at a speed of $2^{\circ} 2 \Theta$ per minute, and the responses were plotted as diffractograms on graph paper (S.J. Sutley, USGS, written commun., 1990). The relative concentrations of 13 minerals in each sample were estimated on the resulting diffractograms using the best d-spacing peak or peaks for which no interferences from other mineral phases were present (table 1). For each selected mineral, the peak

Table 1. d-Spacings and diffraction peaks used to determine peak heights used to show the relative abundances of minerals in drill core samples, Red Mountain, Arizona.

[The peak heights are listed in the associated data for this publication (Horton and others, 2020)]

\begin{tabular}{lcc}
\hline \multicolumn{1}{c}{ Mineral } & $\begin{array}{c}\text { d-Spacing } \\
\text { (Ångstroms) }\end{array}$ & $\begin{array}{c}\text { Diffraction peak, in } \\
\text { Miller indices (hkl) }\end{array}$ \\
\hline Muscovite & 9.95 & 002 \\
Pyrophyllite & 9.20 & 002 \\
Hornblende & 8.48 & 110 \\
Kaolinite & 7.15 & 001 \\
Alunite group & 5.70 & 101 \\
Chlorite & 4.73 & 003 \\
Quartz & 4.25 & 100 \\
Orthoclase & 3.24 & 002 \\
Plagioclase & 3.19 & 040 \\
Calcite & 3.03 & 104 \\
Hematite & 2.69 & 104 \\
Magnetite & 2.53 & 311 \\
Hematite & 1.69 & 116 \\
Pyrite & 1.63 & 311 \\
\hline
\end{tabular}

height was recorded as the number of graph squares above background along a vertical line centered on the peak. For discussion purposes, this height is given in numerical "units" in this report. The resulting data are tabulated and available in the companion data release (Horton and others, 2020). No direct relation was established between individual peak heights and the actual weight percentage of a given mineral. The tabulated peak heights thus represent semiquantitative concentrations.

\section{Results and Evaluation of the Core Analyses}

The analyses for 44 elements in the 818 core samples are summarized in table 2 available in the data release (Horton and others, 2020). The median concentration values are deemed to provide the best measure of the typical concentration for each element (Reimann and others, 2008). For comparison purposes, the estimated abundance values for the Earth's upper or total continental crust for each element are also listed. Beginning with Clarke (1924), many authors have attempted to compile estimates of abundance values for elements in the Earth's crust, either for the entire crust or for the upper and lower parts of the crust (for example, Goldschmidt, 1954; Mason and Moore, 1982; Parker, 1967; Rudnick and Gao, 2014; Taylor and McClennan, 1995; Turekian and Wedepohl, 1961; Wedepohl, 1969-1978, 1995; Yan and Chi, 2005).

Except for tellurium (Te), the abundance concentrations given in Rudnick and Gao (2014) for the upper continental crust are shown in table 2. Until recently, the abundance of tellurium in the total crust or in the upper continental crust had not been accurately determined, mainly because no analytical methods existed to accurately measure extremely low concentrations (nanograms per gram $[\mathrm{ng} / \mathrm{g}]$, or parts per billion $[\mathrm{ppb}]$ ) of this element. For purposes of this report, the value of $0.005 \mathrm{ppm}$ tellurium estimated by Wedepohl (1995) for the total continental crust is used as an acceptable estimate of the tellurium concentration in the upper continental crust.

Ratios of the median concentration values of the elements present at depth in the Red Mountain deposit (Column A) to crustal abundance concentrations, which were selected as an arbitrary reference database (Column B), are given in table 2 . These ratios give first approximation estimates of the relative enrichment or depletion of elements in the area of the PCD at Red Mountain.

Reimann and de Caritat (2000) argue that, because many factors affect the variability of a given element in regional data, comparing analytical concentrations determined in various media to crustal abundance concentrations is not useful, at least for environmental studies. However, crustal concentrations offer at least a qualitative reference base for estimating the enrichment of deposit-related elements in samples collected in the vicinity of the major hypogene $\mathrm{Cu}-\mathrm{Mo}$ deposit at Red Mountain. 
Table 2. Summary of chemical data for 818 drill core samples and comparative background data, Red Mountain, Arizona, and vicinity.

[All concentrations are in parts per million unless \% (percent) is shown after the chemical symbol. Elements analyzed by emission spectrography unless a method abbreviation follows the element symbol. $\mathrm{cm}$ indicates colorimetric analysis. aa indicates atomic-absorption spectrometric analysis. inst indicates instrumental analytical technique. The analytical methods are described in the text and in the associated data for this publication (Horton and others, 2020). ---, indicate no meaningful value. Values preceded by $<$ or $>$ are qualified values, which are less than or greater than, respectively, the value shown. Unqualified samples have no concentrations below the lower limit of determination or above the upper limit of determination. The ratios A/B, A/C, and A/D give estimates of the relative enrichment $(>1.0)$ or depletion $(<1.0)$ of each element in the core samples]

\begin{tabular}{|c|c|c|c|c|c|c|c|c|c|c|c|}
\hline \multicolumn{6}{|c|}{ Drill core data } & \multicolumn{6}{|c|}{ Comparative background data } \\
\hline Element & $\begin{array}{c}\text { Range of } \\
\text { values }\end{array}$ & $\begin{array}{l}\text { Number } \\
\text { analyzed }\end{array}$ & $\begin{array}{c}\text { Percent } \\
\text { analyzed } \\
\text { of } 818 \\
\text { samples }\end{array}$ & $\begin{array}{c}\text { Percent } \\
\text { unqualified } \\
\text { of } 818 \\
\text { samples }\end{array}$ & $\begin{array}{l}\text { Median } \\
\text { value core } \\
\text { samples } \\
\text { (A) }\end{array}$ & $\begin{array}{c}\text { Crustal } \\
\text { abundance } \\
\text { (B) }\end{array}$ & $\begin{array}{l}\mathrm{A} / \mathrm{B} \\
\text { ratio }\end{array}$ & $\begin{array}{l}\text { Median value } \\
27 \text { local } \\
\text { andesite } \\
\text { samples }^{2} \text { (C) }\end{array}$ & $\begin{array}{l}\mathrm{A} / \mathrm{C} \\
\text { ratio }\end{array}$ & $\begin{array}{l}\text { Median value } \\
46 \text { regional } \\
\text { andesite } \\
\text { samples }^{3} \text { (D) }\end{array}$ & $\begin{array}{l}\mathrm{A} / \mathrm{D} \\
\text { ratio }\end{array}$ \\
\hline $\mathrm{Ag}$ & $<0.5-150$ & 818 & 100 & 75 & 0.70 & 0.053 & 13.2 & $<0.008$ & $>8.75$ & $<0.50$ & $>1.4$ \\
\hline As-cm & $<1.0-650$ & 818 & 100 & 95 & 6.0 & 4.8 & 1.25 & 6 & 1.0 & 5.3 & 1.13 \\
\hline B & $<10-700$ & 818 & 100 & 88 & 15 & 17 & 0.88 & --- & --- & 15 & 1.00 \\
\hline $\mathrm{Ba}$ & $100-5,000$ & 818 & 100 & 100 & 700 & 628 & 1.11 & 851 & 0.82 & 1,000 & 0.70 \\
\hline $\mathrm{Be}$ & $<1.0-2.0$ & 818 & 100 & 74 & 1.0 & 2.1 & 0.48 & 2 & 0.50 & 1 & 1.00 \\
\hline $\mathrm{Bi}$ & $<10-500$ & 818 & 100 & 5 & --- & 0.16 & --- & $<1$ & --- & $<2$ & --- \\
\hline $\mathrm{Ca}(\%)$ & $<0.05-5.00$ & 818 & 100 & 84 & 0.20 & 2.57 & 0.078 & 3.62 & 0.055 & 1.75 & 0.11 \\
\hline Cs & $<10-150$ & 818 & 100 & 67 & 10 & 4.9 & 2.04 & --- & --- & 50 & 0.20 \\
\hline $\mathrm{Cu}$ & $5-20,000$ & 818 & 100 & 100 & 700 & 28 & 25 & 47 & 14 & 40 & 17.5 \\
\hline F-inst & $100-1,000$ & 73 & 9 & 9 & --- & 557 & --- & --- & --- & --- & --- \\
\hline $\mathrm{Fe}(\%)$ & $<0.05-15$ & 818 & 100 & 99.9 & 5.00 & 3.92 & 1.28 & 5.22 & 0.96 & 3.00 & 1.67 \\
\hline Hg-inst & $<0.02-1.08$ & 818 & 100 & 85 & 0.04 & 0.05 & 0.80 & --- & --- & $<0.02$ & $>2.0$ \\
\hline K (\%)-аa & $<0.10-8.70$ & 818 & 100 & 99.6 & 2.90 & 2.32 & 1.25 & 2.53 & 1.15 & 2.50 & 1.16 \\
\hline $\mathrm{La}$ & $<20-200$ & 818 & 100 & 99 & 50 & 31 & 1.61 & 44 & 1.14 & 60 & 0.83 \\
\hline $\mathrm{Li}$ & $<1-200$ & 818 & 100 & 93 & 10 & 24 & 0.42 & 40 & 0.25 & 100 & 0.10 \\
\hline $\mathrm{Pb}$ & $<10-10,000$ & 818 & 100 & 99.8 & 50 & 17 & 2.94 & 11 & 4.55 & 50 & 1.00 \\
\hline $\mathrm{Rb}$ & $30-500$ & 818 & 100 & 100 & 200 & 84 & 2.38 & --- & --- & 150 & 1.33 \\
\hline S (\%)-inst & $0.005-17.4$ & 818 & 100 & 100 & 1.70 & 0.06 & 27.4 & --- & --- & $<0.05$ & $>34$ \\
\hline Sb-aa & $<1.0-600$ & 818 & 100 & 68 & 2.0 & 0.40 & 5.00 & $<1.0$ & $>2.0$ & $<2$ & $>1.0$ \\
\hline $\mathrm{Sc}$ & $<5-70$ & 818 & 100 & 99 & 15 & 14 & 1.07 & 17 & 0.88 & 15 & 1.00 \\
\hline Sn & $<10-70$ & 818 & 100 & 19 & $<10$ & 2.1 & $<4.7$ & --- & --- & $<10$ & 1.00 \\
\hline Sn-aa & $<2.0-150$ & 194 & 24 & 18 & 2.0 & 2.1 & 0.95 & --- & --- & --- & --- \\
\hline $\mathrm{Sr}$ & $<100-2,000$ & 818 & 100 & 83 & 200 & 320 & 0.625 & 612 & 0.33 & 300 & 0.67 \\
\hline Te-aa & $<0.010-6,000$ & 818 & 100 & 98 & 0.25 & 0.005 & 50 & $<0.1$ & $>2.5$ & $<0.01$ & $>25$ \\
\hline
\end{tabular}


Table 2. Summary of chemical data for 818 drill core samples and comparative background data, Red Mountain, Arizona, and vicinity.

[All concentrations are in parts per million unless \% (percent) is shown after the chemical symbol. Elements analyzed by emission spectrography unless a method abbreviation follows the element symbol. $\mathrm{cm}$ indicates colorimetric analysis. aa indicates atomic-absorption spectrometric analysis. inst indicates instrumental analytical technique. The analytical methods are described in the text and in the associated data for this publication (Horton and others, 2020). ---, indicate no meaningful value. Values preceded by $<$ or $>$ are qualified values, which are less than or greater than, respectively, the value shown. Unqualified samples have no concentrations below the lower limit of determination or above the upper limit of determination. The ratios A/B, A/C, and A/D give estimates of the relative enrichment $(>1.0)$ or depletion $(<1.0)$ of each element in the core samples]

\begin{tabular}{|c|c|c|c|c|c|c|c|c|c|c|c|}
\hline \multicolumn{6}{|c|}{ Drill core data } & \multicolumn{6}{|c|}{ Comparative background data } \\
\hline Element & $\begin{array}{c}\text { Range of } \\
\text { values }\end{array}$ & $\begin{array}{l}\text { Number } \\
\text { analyzed }\end{array}$ & $\begin{array}{c}\text { Percent } \\
\text { analyzed } \\
\text { of } 818 \\
\text { samples }\end{array}$ & $\begin{array}{l}\text { Percent } \\
\text { unqualified } \\
\text { of } 818 \\
\text { samples }\end{array}$ & $\begin{array}{l}\text { Median } \\
\text { value core } \\
\text { samples } \\
\text { (A) }\end{array}$ & $\begin{array}{c}\text { Crustal } \\
\text { abundance }^{1} \\
\text { (B) }\end{array}$ & $\begin{array}{c}\text { A/B } \\
\text { ratio }\end{array}$ & $\begin{array}{c}\text { Median value } \\
27 \text { local } \\
\text { andesite } \\
\text { samples }^{2} \text { (C) }\end{array}$ & $\begin{array}{c}\mathrm{A} / \mathrm{C} \\
\text { ratio }\end{array}$ & $\begin{array}{l}\text { Median value } \\
46 \text { regional } \\
\text { andesite } \\
\text { samples }^{3} \text { (D) }\end{array}$ & $\begin{array}{l}A / D \\
\text { ratio }\end{array}$ \\
\hline Th & $<100-<100$ & 818 & 100 & 0 & --- & 10.5 & --- & 17 & --- & 15.4 & $\begin{array}{c}-- \\
--\end{array}$ \\
\hline $\operatorname{Ti}(\%)$ & $0.10-1.00$ & 818 & 100 & 100 & 0.50 & 0.38 & 1.32 & 0.62 & 0.81 & 0.50 & 1.00 \\
\hline U-inst & $0.06-36$ & 818 & 100 & 100 & 1.10 & 2.7 & 0.41 & --- & --- & 1.90 & 0.58 \\
\hline $\mathrm{V}$ & $10-700$ & 818 & 100 & 100 & 100 & 97 & 1.03 & 93 & 0.52 & 100 & 1.00 \\
\hline $\mathrm{W}$ & $<50-150$ & 818 & 100 & 5 & --- & 1.9 & --- & --- & --- & $<50$ & --- \\
\hline W-cm & $<1.0-100$ & 204 & 25 & 32 & 5.0 & 1.9 & 2.63 & --- & --- & --- & --- \\
\hline $\mathrm{Y}$ & $<10-150$ & 818 & 100 & 96 & 20 & 21 & 0.95 & 23 & 0.87 & 20 & 1.00 \\
\hline
\end{tabular}

${ }^{1}$ Values, except tellurium, are from compilation of Rudnick and Gao (2014) for upper continental crust. Value for tellurium is from Wedepohl (1995) for entire continental crust.

${ }^{2}$ Subset of the 122 samples in the rock dataset (table 4) consisting of analyses of unaltered or slightly propylitically-altered andesite rock samples collected within the study area but outside of the area of influence of the Red Mountain deposit.

${ }^{3}$ Subset of unaltered or slightly propylitically-altered andesite rock samples collected generally from the area immediately north of the study area. Sample analyses are from the U.S. Geological Survey National Geochemical Database. 
Because Reimann and Caritat (2000) state that crustal abundances do not always provide a good reference database for establishing estimated threshold values (the value above [or in some cases below] which concentrations are considered to be anomalous), two additional databases of median values for elements have been compiled to provide more localized threshold estimates that better determine concentration gains and losses in the overall Red Mountain mineral system (table 2). The first database consists of median values of analyses compiled from a subset of samples from the rock dataset of 122 samples (table 4) collected over and around Red Mountain (Column C). This subset comprises 27 samples of unaltered or slightly propylitically altered andesite collected in the study area but from outside of the area affected by the Red Mountain deposit. The second database consists of median values of 46 similar rock samples of the same andesite formation but collected from the area immediately north of the study area. The analyses of these samples are from the USGS National Geochemical Database (Column D).

The ratio values $\mathrm{A} / \mathrm{C}$ and $\mathrm{A} / \mathrm{D}$ (table 2) from these two databases provide comparisons that emphasize those elements mostly added to the pre-mineral host rocks during the various episodes of mineralization and alteration. These elements include, in approximate order of enrichment in $\mathrm{A} / \mathrm{C}$ and (or) A/D: S, Te, Cu, Au, Ag, Tl, Pb, Hg, Sb, Mo, Zn, Rb, K, and As. (References to $\mathrm{S}$ in this report imply total $\mathrm{S}$ unless sulfate $\mathrm{S}$ is stated.) The A/B ratios, based on crustal abundance values, also show that most of these same elements have been added to the system in approximately the same order. Most of the deposit-related elements tend to occur in one of two common hydrothermal mineral associations: (1) metal-rich sulfide and sulfate minerals or (2) potassium-rich silicate or sulfate minerals. Insufficient information is available to calculate ratio values for four other deposit-related elements, bismuth, cadmium, tin, and tungsten.

\section{R-Mode Factor Analysis}

Factor analysis is a technique that can be used with multielement chemical datasets to identify element associations, including both temporal and spatial associations, in mineral deposits. Such associations help to identify those elements related mostly to host-rock chemistry and those associated mostly with deposit-related minerals. Element associations can also be used to identify changes in these associations between lithologies as well as between the hypogene environment of a deposit and its supergene and weathering environments.

The chemical analyses of the core samples were evaluated by applying R-mode factor analysis, a mathematical technique that is used in geochemistry to describe the covariance relations among element concentrations that produce subsets (factors) of the variables (chemical elements) in a multielement dataset. In the present study, the factors produced were studied to see whether they were related to certain lithologies, to the mineral deposit, or both. The relative degree with which a given element associates with a given factor is called its factor loading value. Further details about factor analysis and its applications to geochemistry can be found in the literature (for example, Bolivar and others, 1983; Davis, 1973; Howarth, 1983; Reimann and others, 2002; Selinus, 1983).

Analyses of two groups of core samples selected from samples from the fence of seven holes (Horton and others, 2020) were evaluated using factor analysis. The first group includes samples collected at depths below the zone of supergene enrichment that represent the deep zones of the hypogene $\mathrm{Cu}-\mathrm{Mo}$ deposit, where copper concentrations are mostly greater than or equal to $(\geq) 2,000 \mathrm{ppm}$. Most of the 254 samples in this group are from the andesite unit (fig. 5). The second group comprises 171 samples with copper $\geq 2,000 \mathrm{ppm}$ that were collected mostly from the rhyolite tuff unit in the part of the zone of supergene enrichment that was largely unaffected by later weathering. For each of the two datasets, 34 elements were found to have acceptable numbers of analyses above their respective lower limits of determination.

Before the factor analysis was run on the two datasets, all analyses originally reported by the analysts with a concentration qualified with the letter "N" (not detected at the lower limit of determination accompanying the letter), "L" (detected but at a concentration less than the accompanying number), or " $\mathrm{G}$ ", (detected at a concentration greater than the accompanying number) were first replaced with new concentrations, The concentrations qualified with an "N" were replaced by a value equal to 0.5 times the concentration given as the lower limit of determination. In a similar manner, the concentrations qualified with an "L" were replaced by a value equal to 0.7 times the lower limit of determination, and concentrations qualified with a "G" were replaced with a value equal to 1.4 times the upper limit of determination accompanying the letter. Frequency distribution histograms for the 34 elements were examined, and the type of distribution for each element was determined. Analyses for all but six elements (Fe, La, Rb, Tl, Y, and Zr) in each dataset showed distributions that most closely approximated a lognormal distribution. The analyses for the 28 remaining elements were converted to logarithms. Four other elements of interest $(\mathrm{Bi}, \mathrm{Cd}, \mathrm{F}$, and $\mathrm{W})$ were highly censored (that is, contained very few analyses not qualified with "N," "L," or "G"), and their frequency-distribution patterns could not be determined.

The principal factor analysis method was used with a varimax rotation (Reimann and others, 2002). Factor models ranging from 7 to 10 factors were examined for each of the two datasets, and 8-factor models were selected as best representing known geological and chemical conditions in the study area. Table 3 shows the factors and their loading values for the hypogene zone dataset. This model accounts for 70 percent of the variance in the data. Table 3 also shows the factors and their loading values for the supergene zone dataset. This model accounts for 65 percent of the variance in the data. Negative loading values are shown where they are less than a value of -0.50 . These negative values define those elements least likely to be associated with the elements loaded positively in 


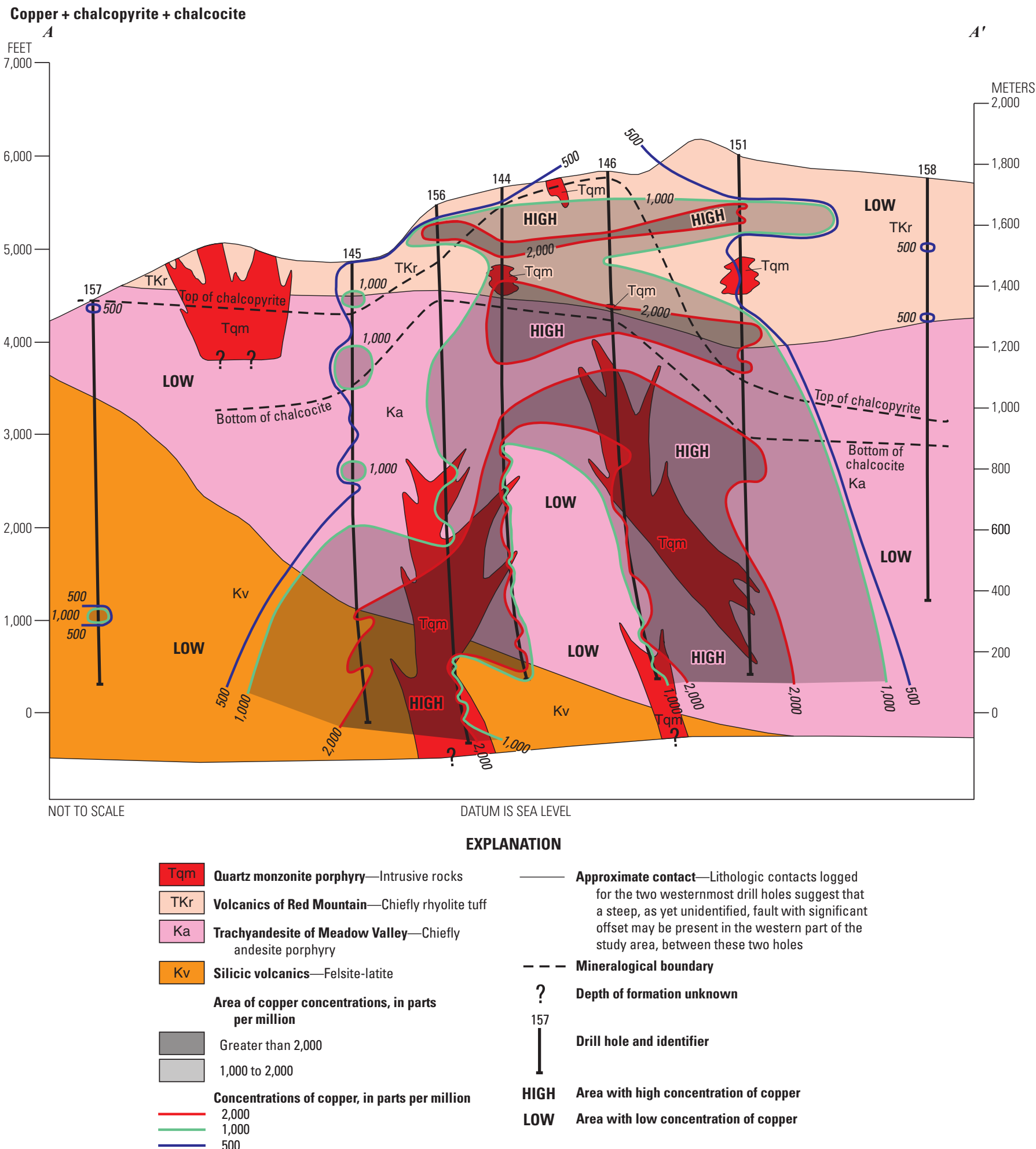

Figure 5. Distributions of copper, chalcopyrite, and chalcocite in core samples. 
the same factor. The criteria described in Reimann and others (2002) require that the number of samples for a robust factor analysis be at least eight times the number of variables in a given dataset. Clearly the two datasets (254 and 171 samples, respectively, and 34 variables) do not meet this standard and thus the results must be viewed with caution.

Identifying the mineral host or hosts for the selected elements determined for this study helps in understanding the genesis of the formation of the Red Mountain $\mathrm{Cu}-\mathrm{Mo}$ deposit. However, no chemical analyses of the host minerals have been done for most of the elements described below. Comments for many element and mineral associations and mineral hosts in the succeeding paragraphs are based on information presented in published reports or on observations of core specimens or outcrops. In many cases the mineral hosts have not been determined. Possible hosts noted in the literature have been given where appropriate, but for the most part, these hosts are considered speculative.

The hypogene zone dataset (table 3 ) shows two factors (Factors 1 and 3 ) that are predominantly related to accessory minerals in the andesite lithology and six factors (Factors 2, 4, $5,6,7$, and 8) containing elements related to hypogene sulfide minerals or to associated alteration minerals. The elements in Factor 1 include (in order of loading values from highest to lowest) $\mathrm{Ni}, \mathrm{V}, \mathrm{Co}, \mathrm{Cr}, \mathrm{Fe}, \mathrm{Sc}, \mathrm{Ti}$, and $\mathrm{Mg}$. When these ferride elements occur together, it usually means that they are mostly associated with igneous iron-rich accessory minerals such as magnetite, micas, and amphiboles. These minerals have been observed in cores from the andesite unit. Iron is also a major constituent of the copper-associated minerals, pyrite and chalcopyrite; however, iron is most strongly associated only with the suite of ferride elements. Unpublished analyses

Table 3. Factor loading values for core samples from the hypogene and supergene zones, Red Mountain, Arizona.

[Negative loading values shown where they are less than a value of -0.50 . Negative loading values define those elements least likely to be associated with the elements loaded positively on the same factor]

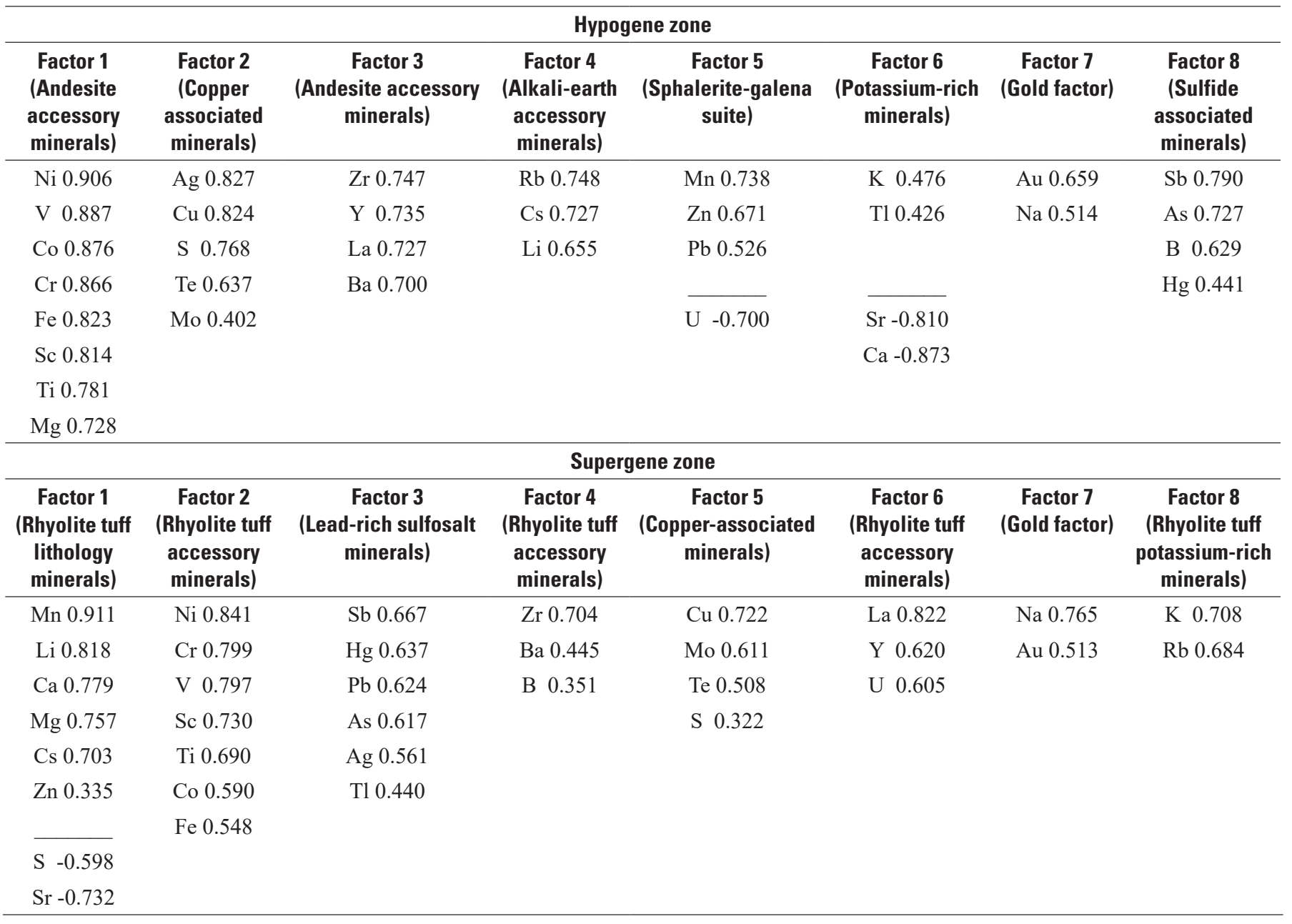


of pyrite concentrates from the Red Mountain area generally show relatively high concentrations of cobalt; thus, cobalt may also be hosted in pyrite. The elements in Factor 3 (Zr, Y, La, and $\mathrm{Ba}$ ) are commonly found in accessory minerals that here are related to host-rock lithology. Factor 2 includes most of the hypogene copper-associated elements (in order, $\mathrm{Ag}, \mathrm{Cu}$, $\mathrm{S}, \mathrm{Te}$, and Mo). All of these elements except molybdenum are known to be hosted in chalcopyrite. Analyses of rocks from PCDs in Russia (Sindeeva, 1964) describe the presence of tellurium. Unpublished data of the author indicate that tellurium is also present in pyrite at Red Mountain. Molybdenum is also associated with this copper factor, confirming observations in core samples that chalcopyrite and molybdenite occur in veins together. The elements in Factor 4 (rubidium, cesium, lithium) can proxy for potassium in minerals such as orthoclase (Heier and Billings, 1970a, 1970b, 1970c); however, their respective mineral residences at Red Mountain have not been determined.

Factor 5 includes manganese, zinc, and lead. In the hypogene zone, lead and zinc commonly occur together in veins as galena and sphalerite, respectively. Manganese is known to proxy in both sphalerite and galena (Wedepohl, 1978). Factor 6 includes the elements potassium and thallium. Thallium commonly proxies for potassium in potassium-bearing minerals (Albuquerque and Shaw, 1972). These two elements are mainly associated with hydrothermal orthoclase and biotite in the potassic alteration zone and with sericite in the phyllic zone. The large negative values for calcium and strontium in Factor 6 suggest a common depletion of these elements during potassium metasomatism. Factor 7 includes gold and sodium. The reason for this association is not clear but could possibly represent gold deposition associated with sodium-rich inclusions or with sodic feldspars. It may also be just a default association assigned by the mathematical technique, because in hypogene parts of PCDs, gold tends to be hosted in chalcopyrite and (or) pyrite (Crocket, 1974).

Factor 8 includes other deposit-related elements: Sb, As, B, and Hg. Antimony and arsenic commonly substitute together in sulfides such as sphalerite, galena, chalcopyrite, and pyrite (Onishi, 1969), and are also commonly found in minerals such as enargite, famatinite, tetrahedrite, and tennantite. Most of these minerals are present at Red Mountain. Boron in PCDs is most commonly found in the mineral tourmaline, which has been identified in samples of core from scattered locations and is known to occur in the strongly mineralized part of PCDs (Cox, 1986). The overall concentrations of mercury are low in the Red Mountain system, and the mineral residence of this element is unknown. The association of boron with mercury, arsenic, and antimony in factor 8 is not entirely understood but implies a common time and (or) place of deposition for all four elements. These four elements are all associated spatially in high concentrations in the west limb of the deep part of the hypogene deposit.

The eight factors for the supergene zone dataset are also listed in table 3 . In many cases, it is not certain whether the element associations in this zone are (1) related wholly or partly to lithology of the rhyolite tuff; (2) a result of hypogene processes, with or without modification by later supergene processes; or (3) entirely the result of supergene events. The elements in Factors 1, 2, 4, and 6 are related mostly to minerals associated with the rhyolite tuff lithology. The elements in Factors 3, 5, 7, and 8 are related mostly to minerals associated with the peripheral parts of the hypogene $\mathrm{Cu}-\mathrm{Mo}$ deposit.

Factor 1 includes six positively loaded elements (in order of factor-loading values: $\mathrm{Mn}, \mathrm{Li}, \mathrm{Ca}, \mathrm{Mg}, \mathrm{Cs}$, and $\mathrm{Zn}$ ) that exhibit relatively low concentrations in the supergene-affected part of the rhyolite tuff. The low concentrations for zinc indicate that this element, which is highly mobile chemically, has been leached from this zone. The relative low concentrations of the other elements are mainly related to the bulk, pre-mineralization chemistry of the rhyolite tuff unit. In contrast, the negatively-loaded elements on this factor (strontium and sulfur) have relatively high concentrations in this same area and are mostly associated with minerals that are common to the area and are relatively chemically immobile, such as clay minerals (strontium) (Stueber, 1976) and alunite (sulfur). Factor 2 includes a group of ferride elements ( $\mathrm{Ni}, \mathrm{Cr}, \mathrm{V}, \mathrm{Sc}, \mathrm{Ti}, \mathrm{Co}$, and $\mathrm{Fe}$ ) that are commonly associated with iron-rich accessory minerals, especially in the andesite unit. The association in the rhyolite tuff unit is not as clear. The intense alteration in that formation makes visual identification of accessory minerals difficult. Alternatively, at least some of this factor may be related to iron-rich pyrite and chalcopyrite.

Factor 4 includes zirconium, barium, and boron. Boron and barium are commonly associated with tourmaline and barite, respectively, both of which have been observed in drill core associated with the advanced argillic alteration zone, similar to that described for other PCDs (Guilbert and Park, 1986; Gustafson and Hunt, 1975; Knight, 1977; Sillitoe, 1983). Zirconium likely reflects the accessory mineral zircon.

Factor 6 includes lanthanum, yttrium, and uranium; these three trace elements are often found in minerals such as biotite, hornblende, apatite, or monazite (Rogers and Adams, 1974). However, their host minerals at Red Mountain have not been determined.

Factor 5 contains many of the hydrothermal copper-associated elements $(\mathrm{Cu}, \mathrm{Mo}, \mathrm{Te}$, and $\mathrm{S})$. Minerals such as chalcopyrite, molybdenite, enargite, and tennantite have been observed in core samples from this upper part of the deposit. Also observed have been supergene-related chalcocite and ferrimolybdite, the latter of which is probably related to formation of the leached cap (Vikre, 2010). Both ferrimolybdite and molybdenite are present in outcrops on Red Mountain. As noted previously, tellurium can proxy in chalcopyrite.

The hypogene-related elements in Factor 3 for the supergene zone ( $\mathrm{Sb}, \mathrm{Hg}, \mathrm{Pb}, \mathrm{As}, \mathrm{Ag}$, and $\mathrm{Tl}$ ) have also not been strongly leached during supergene enrichment and are thought to be mostly associated with generally insoluble lead-rich minerals. In the supergene zone, observations in core samples indicate that some of the lead is still present as galena. Although not noted in core logs for the fence of drill holes, core logs for other holes have noted the presence of anglesite 
and other lead minerals such as plumbojarosite. As noted for the hypogene zone, the mineral residence for mercury is not known. In this upper part of the deposit system, both mercury and thallium may be substituting in hypogene- or supergene-generated, lead-rich minerals (Albuquerque and Shaw, 1972).

Factor 7 again shows an association of gold with sodium that is not clearly understood in this environment and further suggests a misleading default association assigned by the mathematical technique. In both the hypogene and supergene zones of this deposit, the residency of gold has not been identified.

Factor 8 includes potassium and rubidium. Rubidium commonly proxies in potassium-rich minerals (Heier and Billings, 1970a; 1970b). Both elements probably occur in this part of the supergene zone mostly in potassium-rich minerals such as sericite, alunite, and jarosite.

\section{Distributions of Elements and Minerals in the Subsurface}

Plots of element and mineral concentrations have been made on cross sections for selected elements and minerals (Horton and others, 2020) present in the fence of seven drill holes. The location of this section is shown on figure 2 . The individual sections (figs. 5-39) provide a two-dimensional view of the distribution of various elements and minerals through the approximate vertical center of the Red Mountain PCD. The figures are classified into two general categories: (1) mainly hypogene sulfide-related elements and minerals and (2) mainly lithology- or alteration-related elements and minerals.

The distributions and concentrations of elements and minerals shown on the sections represent a culmination of the original distributions and concentrations in the volcanic host rocks that have been overprinted by two or more hydrothermal events related to formation of the PCD, followed, at least locally, by a supergene event and then by weathering in the near surface part of the deposit. In conjunction with the information provided by the factor analyses, the sections were examined to determine the element distributions that are mostly related to lithology, those that are related to hypogene or supergene events, those that are related to the leached cap, those that might reflect multiple origins, and (or) those that show no obvious spatial relations. Of the 44 elements listed in table 2, 14 (Ba, Be, Cr, Cs, La, Li, Ni, Rb, Sc, Sr, Ti, V, Y, and $\mathrm{Zr}$ ) do not show any meaningful analytical variation or do not clearly delineate areas of element concentration that can be consistently related either to specific lithologic units or to hypogene or supergene alteration or mineralization.
The analyses for three additional elements (bismuth, tin, and tungsten) are too highly censored (have too few analyses above their respective lower limits of determination) to provide meaningful data for factor analysis or for detailed element plots for the entire area of the section. However, they do show restricted but meaningful anomalies, which are described in the succeeding paragraphs.

At Red Mountain, some elements, particularly some of the major elements, contain a component related to the pre-mineralization host-rock chemistry and a component resulting from the chemical overprinting of the host-rock units during formation of the mineral deposit. For comparison purposes, two subsets of analyses were compiled to provide estimates of the pre-mineralization concentration values for selected elements in the andesite unit. The first was established by using analyses of 27 samples of unaltered or weakly propylitically altered andesite from the rock dataset (Horton and others, 2020) that were collected in the study area but outside of the area of the Red Mountain deposit. A second subset was compiled using analyses of 46 similar andesite samples in the USGS National Geochemical Database that were collected generally in the area immediately north of the study area. Table 2 summarizes the range of concentrations and median values for the selected elements, as well as the median concentrations of these two andesite datasets. The median concentration values are deemed to estimate the original or typical threshold concentrations of elements in the andesite unit.

The contour lines were manually drawn, not computer generated, in order to best approximate the effect of the host rock chemistry. Because of local variations in element distributions, the locations of the contour lines should be considered as approximate.

\section{Mainly Hypogene Sulfide-Related Elements and Minerals}

Elements in this category include $\mathrm{Cu}, \mathrm{Ag}, \mathrm{S}$ (as both total $\mathrm{S}$ and sulfate $\mathrm{S}$ ), $\mathrm{Te}, \mathrm{Mo}, \mathrm{Au}, \mathrm{Pb}, \mathrm{Zn}, \mathrm{Hg}$, As, and $\mathrm{Sb}$. Minerals that contain high concentrations of these elements, and for which enough data exist to plot their distributions, include chalcopyrite, chalcocite, anhydrite, and alunite.

Copper, Chalcopyrite, and Chalcocite-Figure 5 shows the distribution of copper, as well as those of visible chalcopyrite and chalcocite, in the core samples. The estimated threshold concentration for copper ranges from 40 to $47 \mathrm{ppm}$ (table 2). Copper exhibits concentrations greater than (>) $100 \mathrm{ppm}$ throughout almost all of the area of the section but is clearly more concentrated in the vertical center of the section. The extent of copper concentrations at depth is controlled by the depth of drilling and has not been completely defined. The lateral extent of anomalous copper concentrations beyond the 
section is unknown but clearly extends to the right (east) of drill hole 158, in which many samples exhibit concentrations exceeding 100 ppm copper (Horton and others, 2020).

For purposes of discussion, the hypogene and supergene parts of the $\mathrm{Cu}-\mathrm{Mo}$ deposit are defined to include areas containing $\geq 1,000 \mathrm{ppm}$ of copper. These areas have been added to all of the succeeding sections (figs. 6-39) for reference. The two limbs of the deep part of the hypogene deposit, are part of the crude, inverted cup configuration of this deposit in two dimensions that are best defined by 2,000-ppm copper contours. These limbs are generally associated spatially with quartz monzonite porphyry intrusive bodies. A second, more restricted mid-level zone $(\geq 2,000 \mathrm{ppm} \mathrm{Cu})$, which contains both chalcopyrite and chalcocite, is present above the deep part of the hypogene deposit, mainly in the andesite unit. This mid-level zone represents an overlapping of hypogene and supergene copper minerals.

In the rhyolite tuff unit, a distinct area outlined by 1,000- and 2,000-ppm copper contours delineates the area most enriched in copper as a result of supergene processes (fig. 5). It is noteworthy that chalcopyrite is still present in the center of the section almost to the present surface, indicating that hypogene mineralization extended at least to that elevation. Visible chalcocite extends to depths of as much as $950 \mathrm{~m}$ below the present surface. The overall depth of chalcocite is shown as an approximate boundary line on figure 5 . Below this line, copper occurs almost entirely as chalcopyrite, occasionally accompanied by bornite. Above this line, chalcocite is commonly observed. Other copper-rich minerals observed in core in this area include enargite, chalcopyrite, tennantite, and minor amounts of covellite. Both 500- and 1,000-ppm copper contours surround the entire deposit, emphasizing that copper concentrations are continuous and anomalous over a large area. In spite of weathering, copper is highly concentrated at the present surface, especially directly above the hypogene $\mathrm{Cu}-\mathrm{Mo}$ deposit. The distributions of copper, chalcopyrite, and chalcocite are in general agreement with those of Lecumberri-Sanchez and others (2013).

Silver--The factor analyses (table 3) show silver associated with copper in the hypogene zone and with lead and other elements in the supergene zone. The estimated threshold value for silver is $<0.008 \mathrm{ppm}$ (table 2). The distributions at depth of high (>1 ppm) silver concentrations (fig. 6) correlate well spatially with the distributions of copper in the deep part of the hypogene deposit (fig. 5). The distributions of similar high silver concentrations in the upper part of the system form a wide zone that is spatially associated with peripheral hypogene and supergene copper and lead minerals. Like copper, silver is anomalous at the present surface.

Total Sulfur, Sulfate Sulfur, Anhydrite, and Alunite.-The threshold value for total sulfur is estimated to be $<0.05$ percent (table 2). Figure 7 shows the distribution of total sulfur, which includes sulfides, sulfates, and other minor mineral forms such as sulfosalts. As observed for copper, sulfur is highly concentrated throughout the entire area of the section. Examination of the drill core indicates that almost all of the sulfide sulfur occurs in pyrite, chalcopyrite, molybdenite, or chalcocite; the amounts of enargite, tennantite, sphalerite, galena, and other sulfur-rich species are relatively minor. A total sulfur anomaly ( $>2.0$ percent) correlates spatially with the deep part of the hypogene $\mathrm{Cu}-\mathrm{Mo}$ deposit. The upper part of the system exhibits the highest concentrations of total sulfur (generally $>4.0$ percent), partly reflecting the more intense pyritization present near the top of the system, as described later for pyrite. The highest sulfur concentrations in this area are also related to chalcocite formed during supergene enrichment. Sulfur is anomalous at the present surface, mainly in the form of sulfate minerals such as alunite. Alunite and both pyrite and molybdenite have been observed locally in outcrops.

Figure 8 shows the distribution of sulfate sulfur, anhydrite, and alunite. The area with the highest $(>0.40$ percent) concentrations of sulfate in the deeper part of the system correlates spatially with the general area of the deep part of the hypogene $\mathrm{Cu}-\mathrm{Mo}$ deposit, and the 0.20 -percent contour correlates spatially, at least in the vertical center of the deposit, with the top of the area containing visible anhydrite. The anhydrite line was determined on the basis of its presence or absence in core samples and not on its relative concentrations. Pervasive hypogene alunite associated with advanced argillic alteration occurs throughout the area above the line marking the base of XRD alunite. Alunite also occurs in the upper $100 \mathrm{~m}$ of the system in younger veins that cut areas of pervasive alunite. This relation can also be seen locally in outcrops. Gypsum, anglesite, jarosite, and barite are also locally present in the upper part of the deposit.

Tellurium.-The estimated threshold value for tellurium ranges from $<0.01$ to $<0.1 \mathrm{ppm}$ and may be as low as the crustal abundance value of $0.005 \mathrm{ppm}$ (table 2). Anomalous $(>0.5 \mathrm{ppm})$ tellurium is spatially associated with the limbs of the deep part of the hypogene deposit and is more concentrated in the (left) west limb (fig. 9). High concentrations of tellurium $(>1 \mathrm{ppm})$ in the upper part of the system are mostly confined to the rhyolite tuff unit and occur in the area exhibiting the highest concentrations of total sulfur (fig. 7) and pyrite.

The broad tellurium anomaly ( $>0.5 \mathrm{ppm})$ in the upper part of the deposit extends locally to the present surface, especially directly above the deep part of the hypogene $\mathrm{Cu}-\mathrm{Mo}$ deposit, indicating that tellurium is relatively immobile chemically in the weathering environment. This near-surface tellurium distribution corroborates the description by Sillitoe (1983) of several porphyry copper deposits that contain tellurium in the enargite zones associated with advanced argillic alteration. 


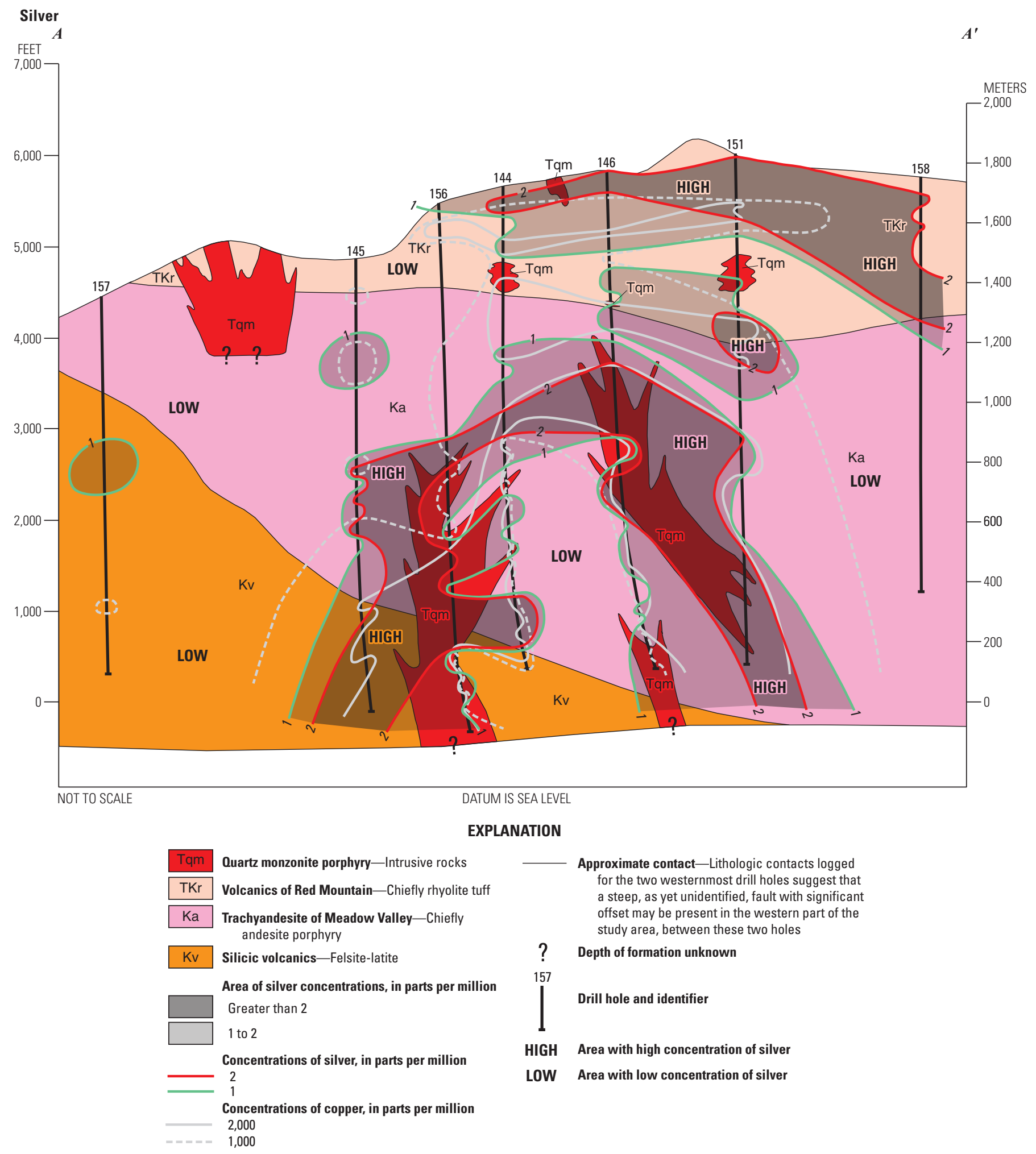

Figure 6. Distribution of silver in core samples. 


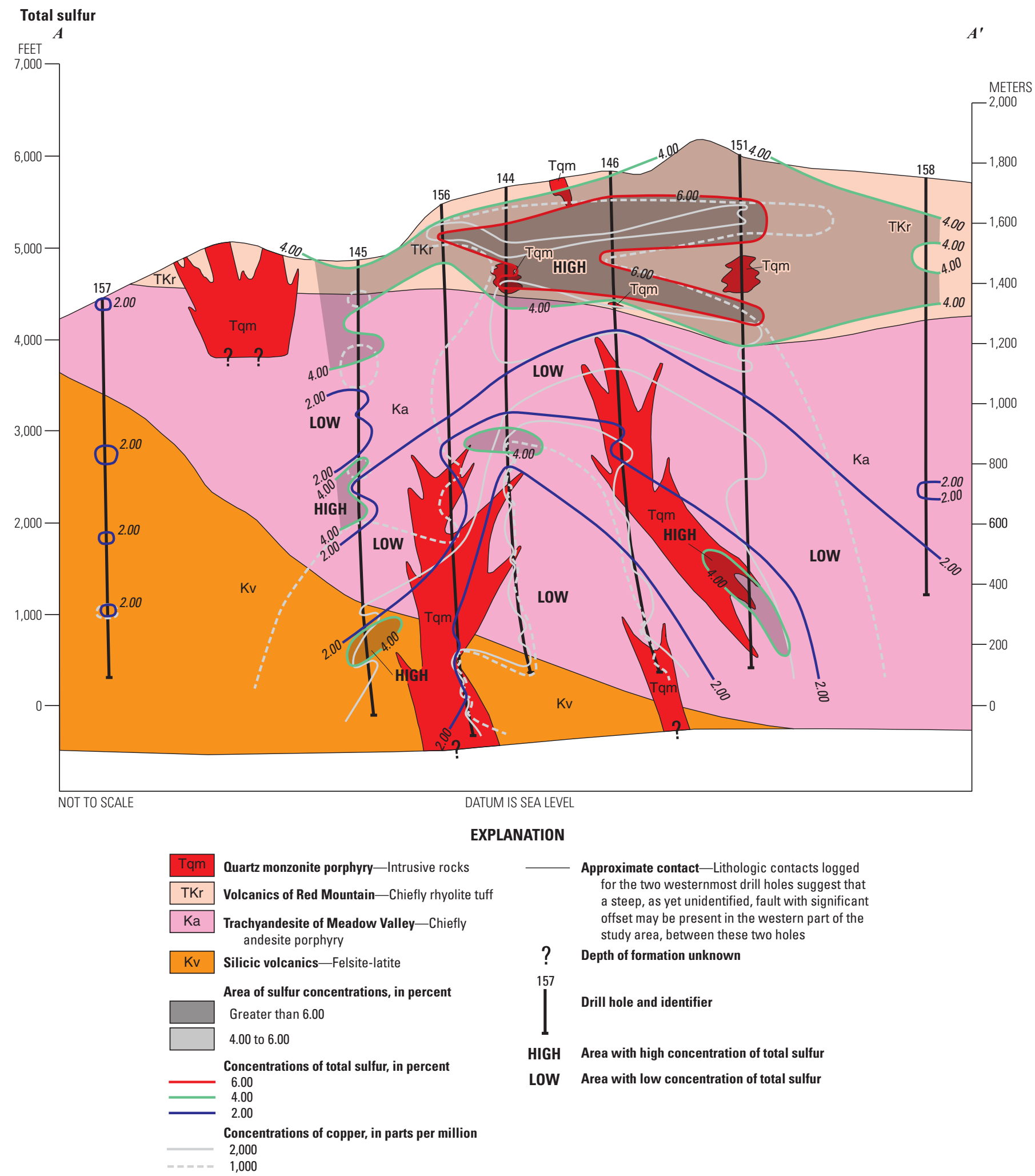

Figure 7. Distribution of total sulfur in core samples. 


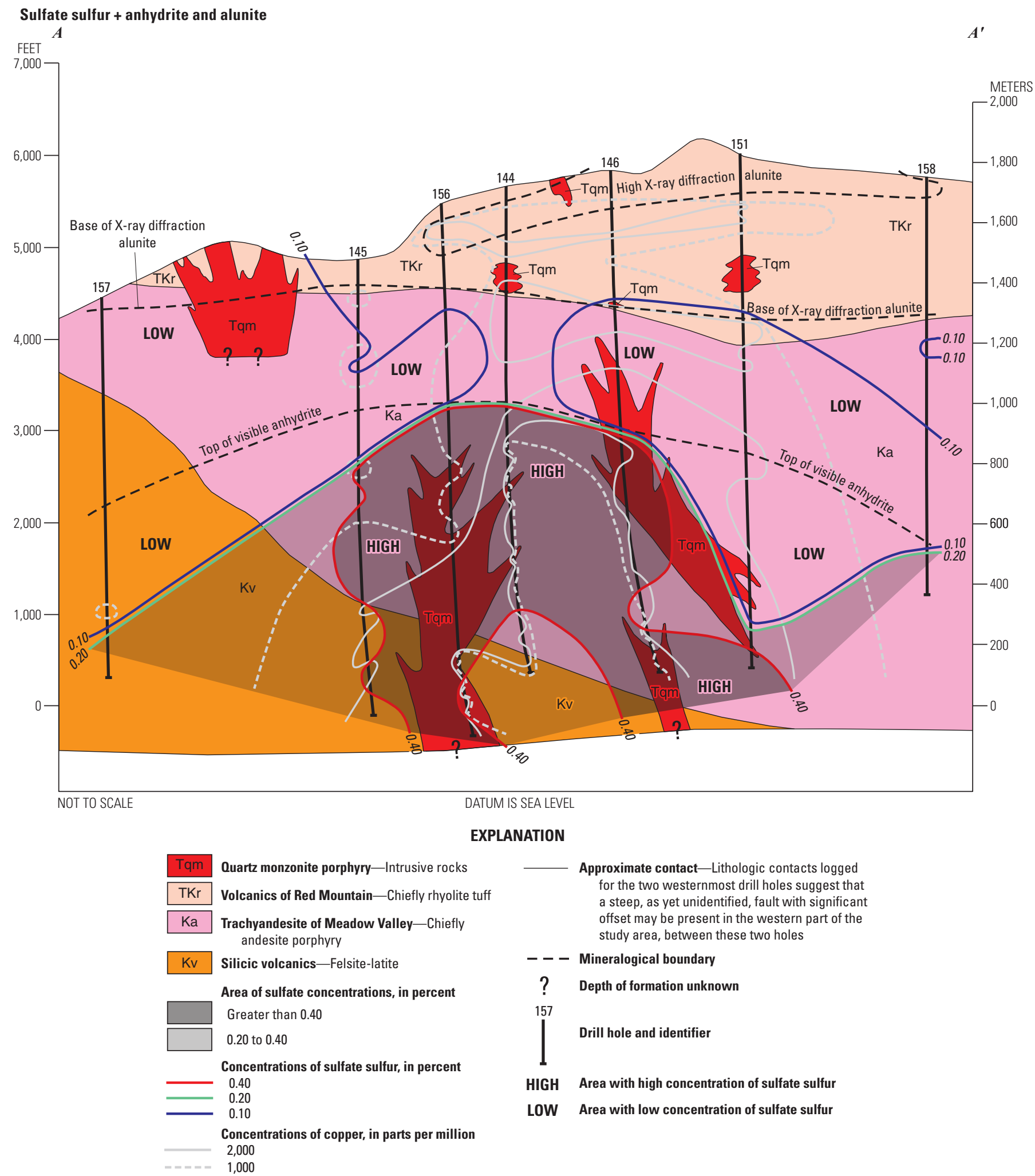

Figure 8. Distributions of sulfate sulfur, anhydrite, and alunite in core samples. 


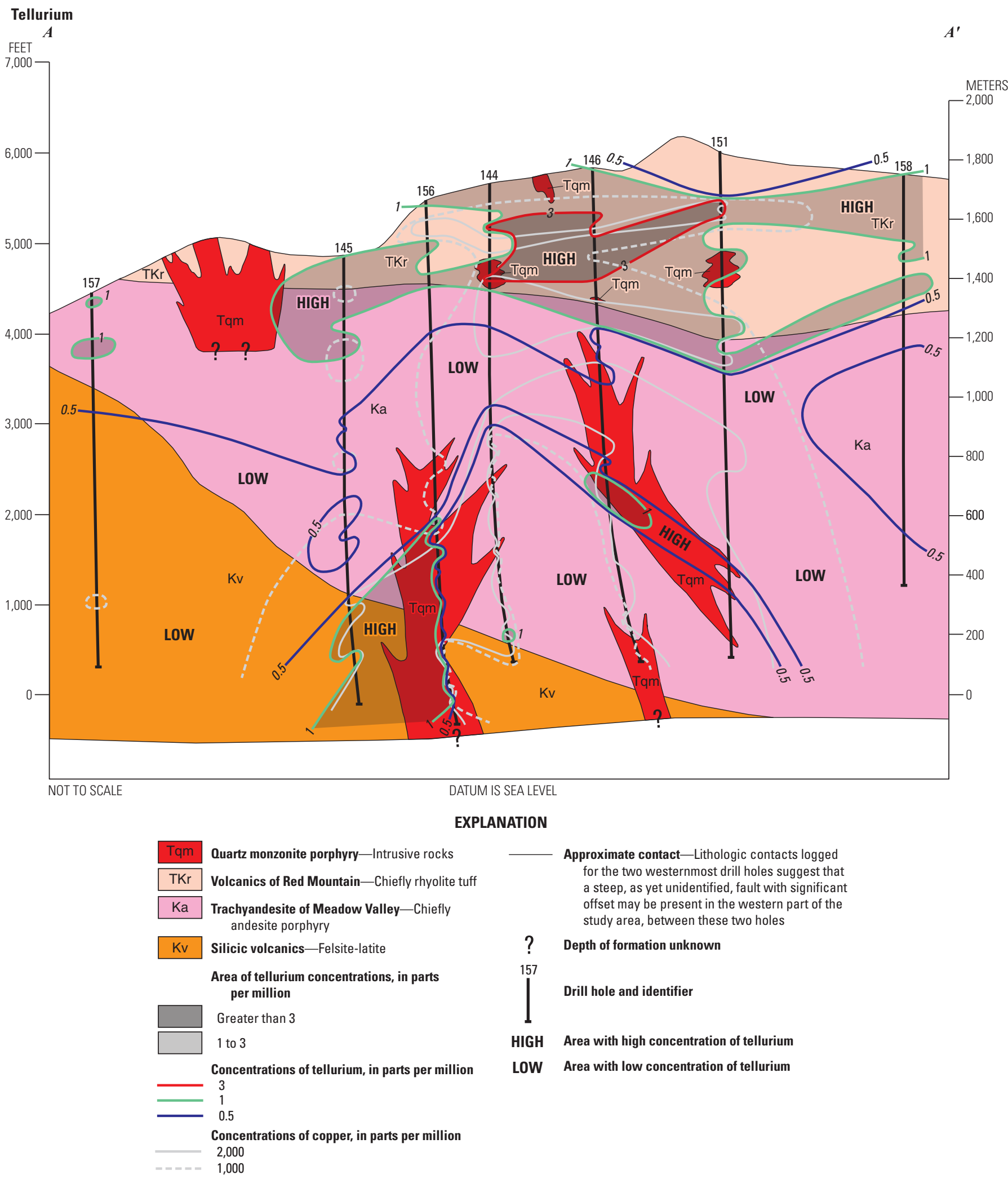

Figure 9. Distribution of tellurium in core samples. 
Molybdenum.-The estimated threshold value for molybdenum is about $3 \mathrm{ppm}$ (table 2). Figure 10 shows the distribution of molybdenum. The relatively few observations of visible molybdenite in core samples and the relatively low chemical concentrations of molybdenum together make defining the complete distribution of molybdenite difficult. High concentrations ( $>20 \mathrm{ppm}$ ) of molybdenum are present in both limbs of the deep part of the hypogene deposit (fig. 10). Unlike some other elements, molybdenum is more concentrated in the right (east) limb and above the east limb. In the deep part of the hypogene deposit, all of the molybdenum occurs as molybdenite. High concentrations ( $>50 \mathrm{ppm})$ of molybdenum are present in the near-surface area directly above the deep hypogene $\mathrm{Cu}-\mathrm{Mo}$ deposit. These distributions are in general agreement with the spatial associations of molybdenum noted by Lecumberri-Sanchez and others (2013). The high concentrations of molybdenum in the nearsurface area are composed of both hypogene molybdenite and ferrimolybdite, the latter of which is probably related to formation of the leached cap (Vikre, 2010).

Gold.-Gold is present in the Red Mountain system. However, overall concentrations are low, as is typically the case for molybdenum-rich PCDs formed in the continental crust environment of the southwestern United States (Kesler, 1973). The estimated threshold value for gold is $<0.002 \mathrm{ppm}$ (table 2). Figure 11 shows the distribution of gold. The overall distribution of the highest concentrations $(>0.05 \mathrm{ppm})$ of gold generally correspond spatially to the areas of deep and mid-level chalcopyrite concentrations (fig. 5) and generally agree with the distribution of gold shown by Lecomberri-Sanchez and others (2013). This distribution implies that gold is probably associated with chalcopyrite. However, pyrite is another possible host. Vikre (2010) notes that supergene enrichment of gold has not been documented in PCDs. However, supergene enrichment of gold has been identified in deposits in deeply weathered laterite terrains in Western Australia, Africa, and South America (Butt, 1988; Monti, 1987). The concentrations $(>0.02 \mathrm{ppm})$ of gold in the near-surface part of the Red Mountain deposit, in an area that coincides approximately with supergene-related copper $>1,000 \mathrm{ppm}$, may have therefore resulted from supergene enrichment. More likely, this near-surface gold concentration represents a separate zone of hypogene gold. Gold is anomalous ( $>0.02 \mathrm{ppm})$ at the present surface.
Arsenic.-The estimated threshold value for arsenic is about 5-6 ppm (table 2). High concentrations ( $>50 \mathrm{ppm}$ ) of arsenic (fig. 12) generally correlate spatially with the left (west) limb of the deep part of the hypogene deposit but not with the right (east) limb at this concentration level. A small mid-level zone containing similar high concentrations of arsenic is also present above the west limb.

The highest concentrations of arsenic (>100 ppm) are found in a broad zone in the uppermost, near-surface part of the system, that may be a broad hypogene halo above the deep hypogene $\mathrm{Cu}-\mathrm{Mo}$ deposit in which arsenic has not migrated as a result of supergene enrichment and (or) weathering. Arsenic is highly concentrated at the present surface, including in the leached cap weathered zone. The factor analysis (table 3), as well as the common distributions of elements, imply that much of the arsenic and antimony concentrations are associated with lead minerals in the uppermost part of the hypogene deposit. Enargite/famatinite and tennantite/tetrahedrite are additional minerals that contain arsenic and (or) antimony. Pyrite is another possible host.

Antimony.-The estimated threshold value for antimony at Red Mountain is not well defined but is probably $<1 \mathrm{ppm}$ (table 2). At depth, antimony exhibits concentrations ( $>2 \mathrm{ppm}$ ) (fig. 13) that are spatially coincident with the limbs in the deep part of the hypogene deposit. Like arsenic, the left (west) limb has higher (>10 ppm) antimony concentrations than does the right (east) limb. Similar to arsenic, high antimony concentrations ( $>10 \mathrm{ppm}$ ) are found in a broad area in the uppermost part of the deposit that may represent a hypogene halo above the deep part of the deposit. In this upper part of the system, the area with $>4$ ppm antimony broadly overlaps the $>10 \mathrm{ppm}$ arsenic zone. Like arsenic, antimony anomalies extend to the present surface. This distribution confirms the data of Levinson $(1974,1980)$ that antimony tends to be relatively immobile.

Mercury. - The threshold value for mercury is estimated to be $<0.02 \mathrm{ppm}$ (table 2). Similar to distributions for arsenic and antimony, high concentrations ( $>0.06 \mathrm{ppm})$ of mercury show a close spatial association with the west limb of the deep part of the hypogene deposit (Fig. 14). A restricted area of high concentrations $(>0.06 \mathrm{ppm}$ ) of probable hypogenerelated mercury is present in part of the uppermost part of the system, directly above the deep part of the hypogene $\mathrm{Cu}-\mathrm{Mo}$ deposit. This restricted area might also represent the remnants of a crude halo around the deep part of the hypogene deposit. Mercury concentrations are low in the near-surface, right (eastern) side of the section, probably because of dispersion of this element in the weathering environment that produced the leached cap. 


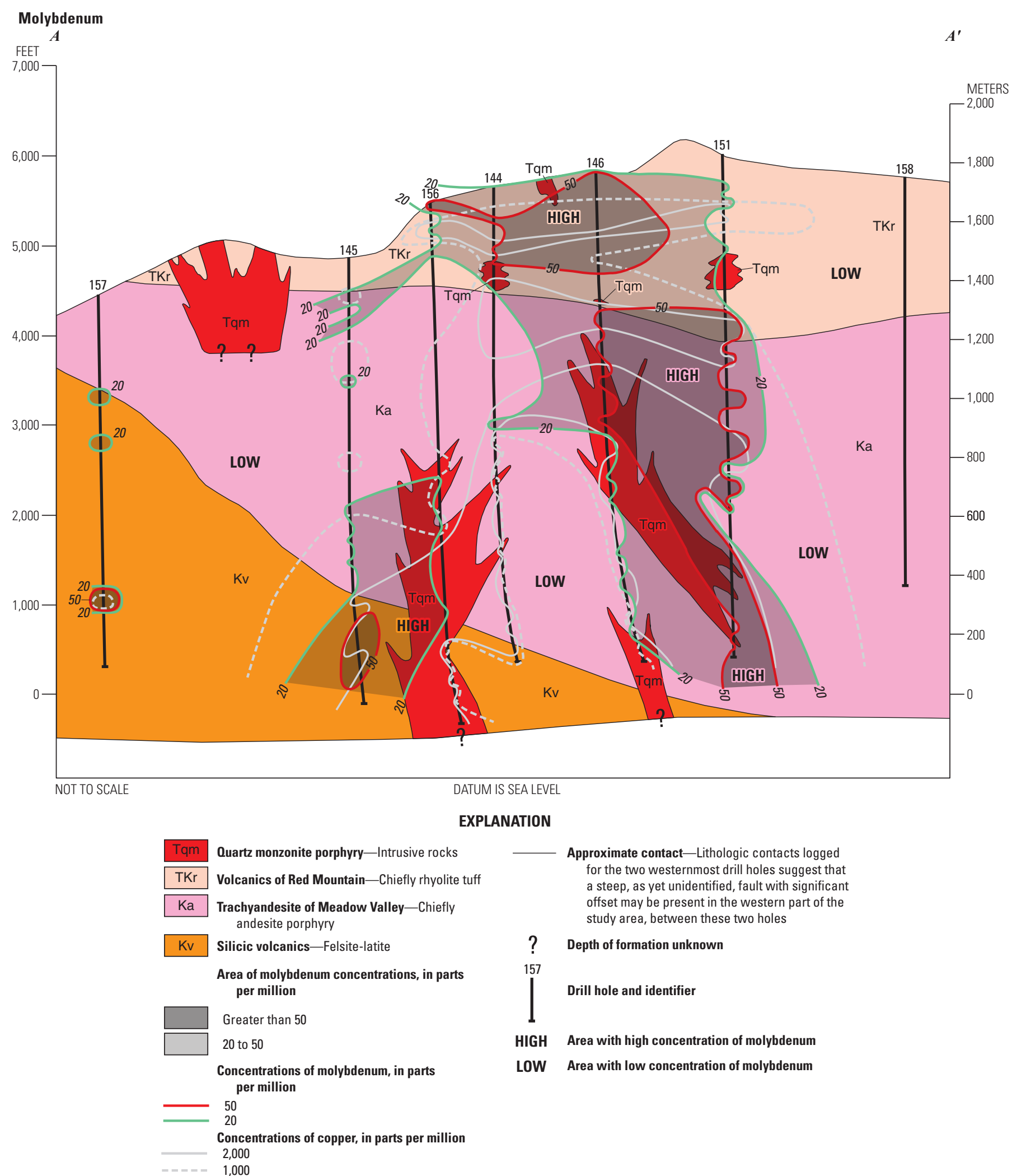

Figure 10. Distribution of molybdenum in core samples. 


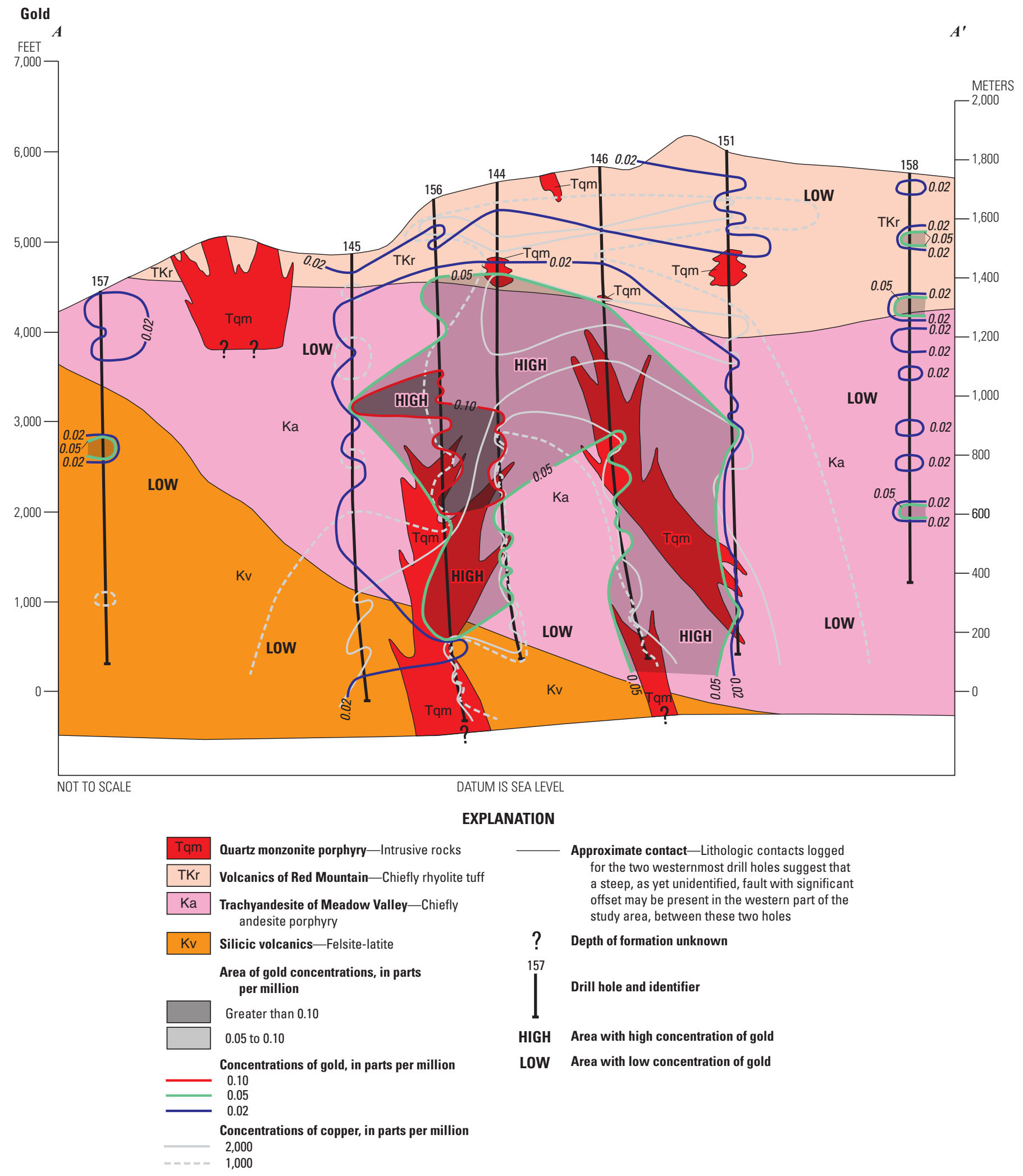

Figure 11. Distribution of gold in core samples. 


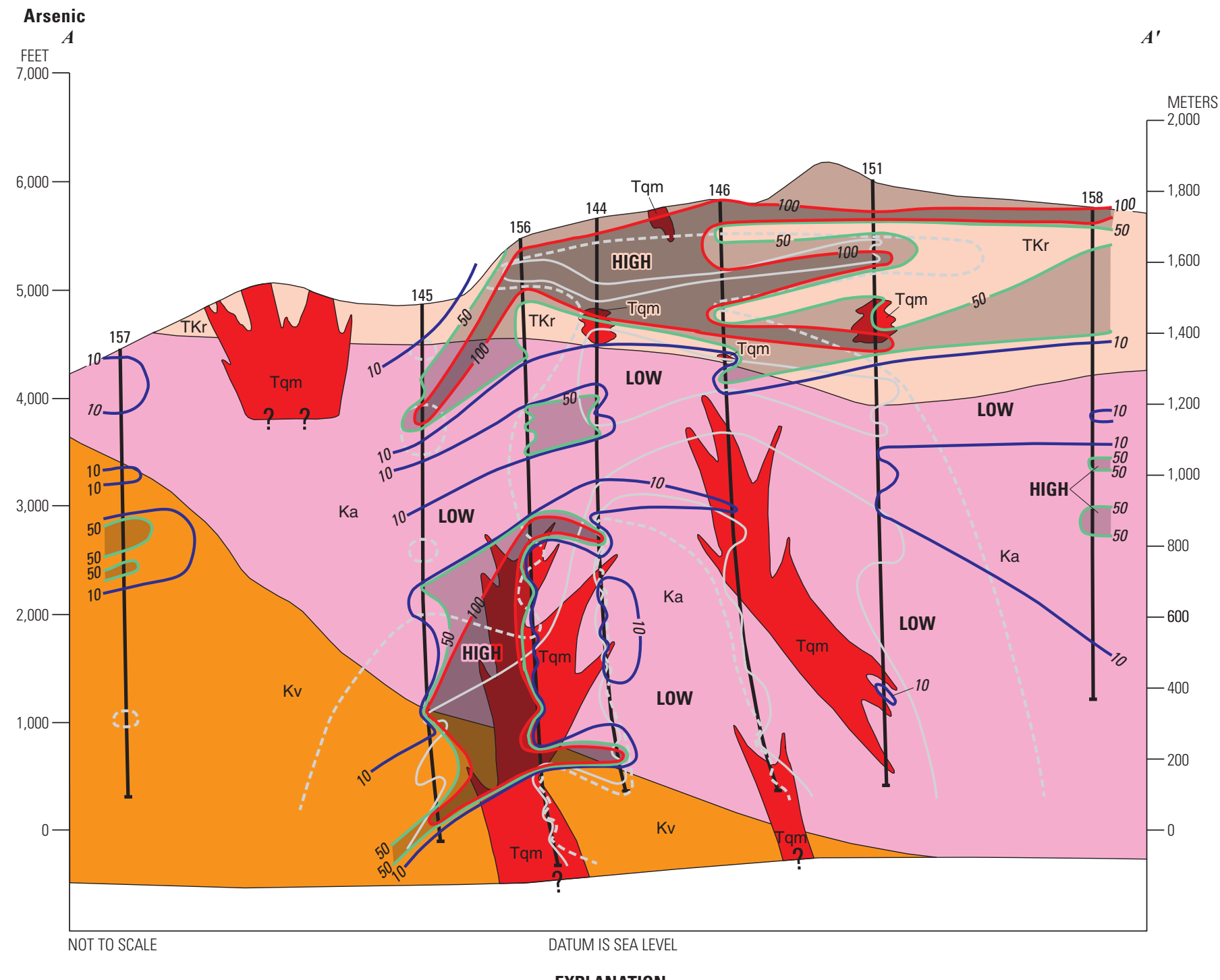

EXPLANATION

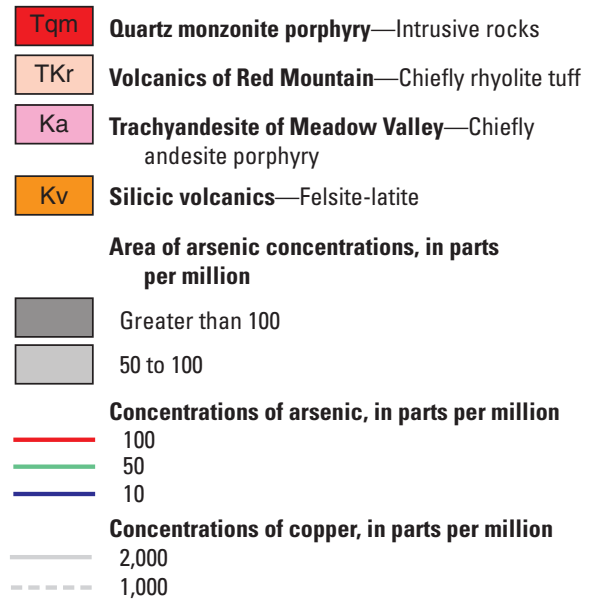

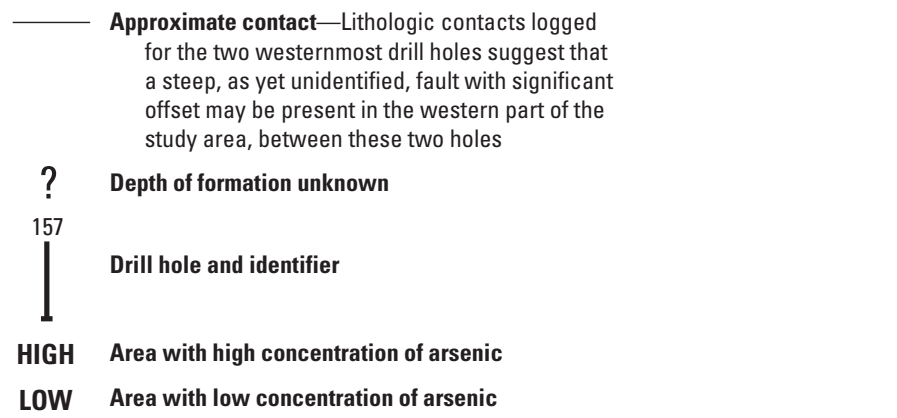

Figure 12. Distribution of arsenic in core samples. 


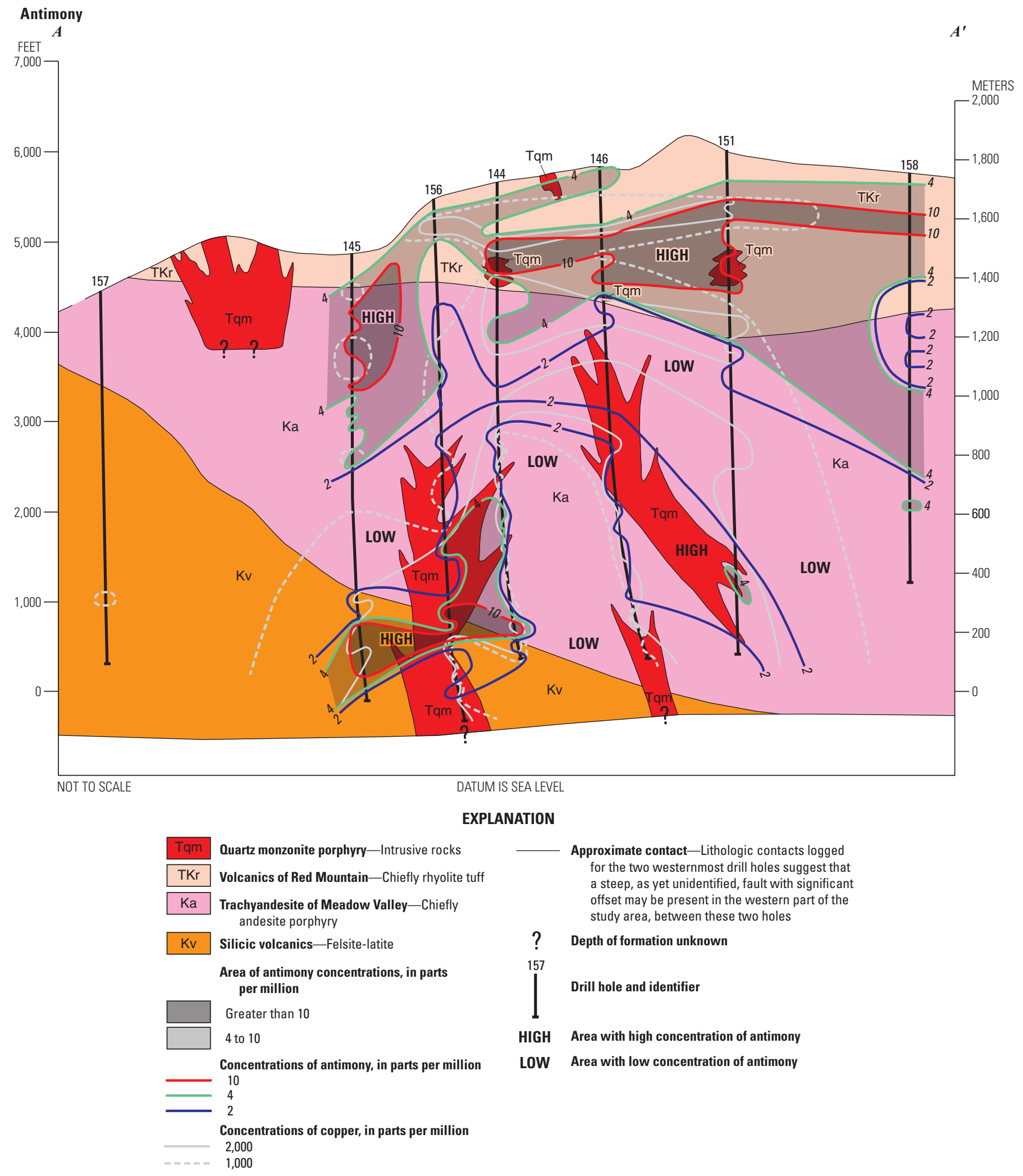

Figure 13. Distribution of antimony in core samples. 


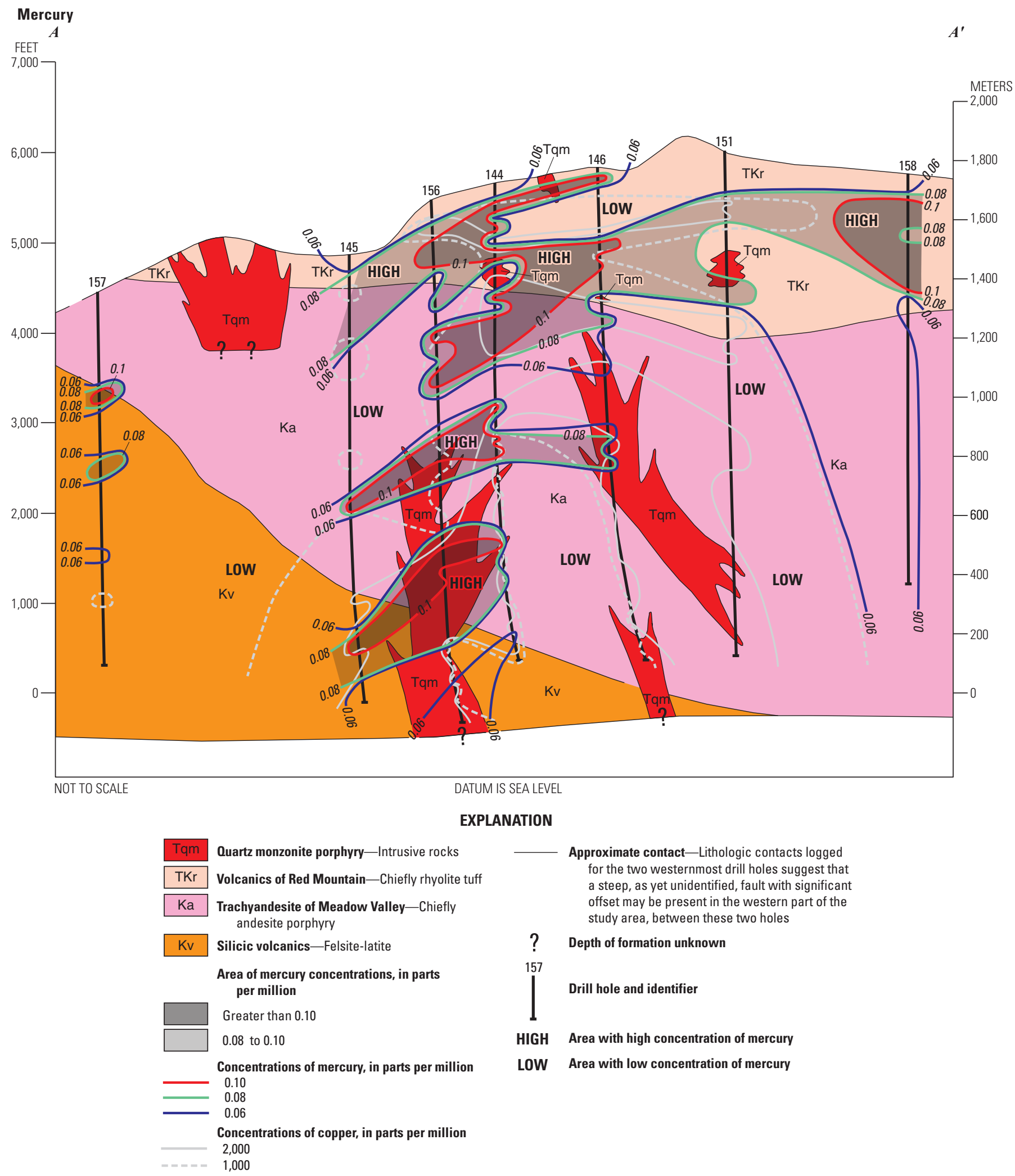

Figure 14. Distribution of mercury in core samples. 
Lead.-The estimated threshold value for lead ranges from 11 to $50 \mathrm{ppm}$ (table 2). The distribution of lead (fig. 15) suggests that the value is probably $<30 \mathrm{ppm}$ and thus closer to the crustal abundance value of $17 \mathrm{ppm}$. Concentrations of lead between 30 and $100 \mathrm{ppm}$ are present in parts of the right (east) limb in the deep part of the deposit but are more highly concentrated ( $>100 \mathrm{ppm})$ in and west of the left (west) limb. The highest lead concentrations $(>500 \mathrm{ppm})$ are in the upper part of the system within a broad area of $>100$ ppm lead. Both hypogene galena and supergene- or weathering-related anglesite have been observed in cores from the near-surface part of the deposit. This broad area could thus be interpreted as a hypogene halo above the deep part of the hypogene deposit that may have been partly altered and enriched by supergene or weathering processes. Lead is relatively immobile in the supergene and weathering environments at Red Mountain and is present in high concentrations at the present surface.

Zinc.- The estimated threshold value for zinc ranges from 60 to 89 ppm (table 2). Like lead and some other elements, zinc is not noticeably concentrated $(>100 \mathrm{ppm})$ in parts of the right (east) limb of the deep part of the deposit (fig. 16) but is most highly concentrated $(>500 \mathrm{ppm})$ in the area of the left (west) limb. Zinc is also generally concentrated in a broad, roughly horizontal zone that extends across the upper mid-level part of the system. As is the case for other elements, this zone may represent the remnants of a broad hypogene halo above the deep part of the Cu-Mo deposit. Unlike lead, zinc is highly mobile in the low $\mathrm{pH}$ environment associated with oxidizing pyrite; thus, the zone of low zinc concentrations at the top of the system reflects leaching of zinc during supergene enrichment and (or) during post supergene weathering related to formation of the leached cap.

Other elements. - Three other analyzed elements (bismuth, tin, and tungsten) are associated with the hypogene events of the PCD at Red Mountain. These elements were not included in the factor analysis because their respective datasets contained too few analyses above their respective lower limits of determination. Accordingly, only the samples with high concentrations of these elements can be evaluated and plotted.

Bismuth.-The mineral residence of bismuth at Red Mountain is not known. It is a common constituent of sulfide minerals such as galena, sphalerite, chalcopyrite, and pyrite (Ahrens and Erlank, 1969), all of which are present in the deposit area. The estimated threshold value for bismuth is not well established but is probably $<1 \mathrm{ppm}$, as compared to the crustal abundance value of $0.16 \mathrm{ppm}$ (table 2). Anomalous concentrations of bismuth in the deep part of the hypogene $\mathrm{Cu}-\mathrm{Mo}$ deposit occur in a few scattered localities (fig. 17). These concentrations range from "10L" (less than the lower limit of determination of $10 \mathrm{ppm}$, which is plotted as $7 \mathrm{ppm}$ ) to $20 \mathrm{ppm}$ except for one sample in the deep part of drill hole 145 that was reported as 500 ppm (Horton and others, 2020). This sample occurs within a 10-ppm contour near the top of the felsite-latite formation. The highest bismuth concentrations, however, are centered mostly in the near-surface part of the system directly above the deep part of the hypogene deposit.
This distribution most closely matches that of lead (fig. 15), with the highest area of bismuth concentrations in a more restricted area than that of lead. This anomalous area is similar to the anomalies of elements such as mercury, tin, thallium, and tungsten. High bismuth concentrations in the uppermost part of the Red Mountain system agree with similar observations noted by Sillitoe (1983) for the Lepanto, Philippines, copper deposit. Bismuth is one of the elements at Red Mountain that represents the most distant manifestations of the deep part of the hypogene deposit. The distribution of near-surface bismuth implies that it is probably located where originally deposited and has not been significantly remobilized by supergene enrichment or subsequent weathering processes.

Tin.- The mineral residence of tin at Red Mountain is not known. No tin minerals were identified in the drill core logs reviewed for this study. Tin is known to occur in micas and other rock-forming minerals and in sulfide minerals (Hamaguchi and Kuroda, 1969). An estimated threshold value for tin could not be determined from the Red Mountain data but is clearly $<10 \mathrm{ppm}$ and probably closer to the crustal abundance value of $2.1 \mathrm{ppm}$ (table 2). Concentrations of tin were detected in a few scattered localities in the area of the deep part of the hypogene $\mathrm{Cu}-\mathrm{Mo}$ deposit (fig. 18). High tin concentrations (including reported concentrations between "10L" [less than the lower limit of determination of $10 \mathrm{ppm}$, plotted as $7 \mathrm{ppm}$ ] and $70 \mathrm{ppm}$ [Horton and others, 2020], which is within the plotted area of the 20-ppm contour) are more widely concentrated in a broad zone in the upper part of the deposit. This latter area corroborates similar observations of Sillitoe (1983) for tin concentrations in the upper parts of other PCDs. The distribution of tin at Red Mountain implies that it may be associated with lead-rich minerals or possibly molybdenum minerals. Some of the tin may also be associated with accessory minerals present in the rhyolite tuff unit. Like bismuth, tin is probably located where it was originally deposited during formation of the hypogene $\mathrm{Cu}-\mathrm{Mo}$ deposit. Tin is also relatively immobile with respect to supergene enrichment and (or) weathering processes and is anomalous at the present surface.

Tungsten.-A reliable estimated threshold value for tungsten could not be determined, but it is clearly $<50 \mathrm{ppm}$ and probably is closer to the crustal abundance value of $1.9 \mathrm{ppm}$ (table 2). The mineral residence of tungsten at Red Mountain is also not known. At low concentrations, such as those present there, tungsten can substitute for molybdenum. This substitution may be the case at Red Mountain because tungsten anomalies, including reported concentrations between " $50 \mathrm{~L}$ " (less than the lower limit of determination of $50 \mathrm{ppm}$, plotted as $30 \mathrm{ppm}$ ) and $150 \mathrm{ppm}$ ([Horton and others, 2020], which is within the plotted area of the 50-ppm contour) (fig. 19), particularly in the near-surface part of the deposit, generally occur where molybdenum is most highly concentrated (fig. 10). This restricted near-surface tungsten anomaly is probably located where tungsten was originally deposited. Tungsten, another element that is relatively immobile with respect to supergene enrichment and (or) weathering processes at Red Mountain, is anomalous at the present surface. 


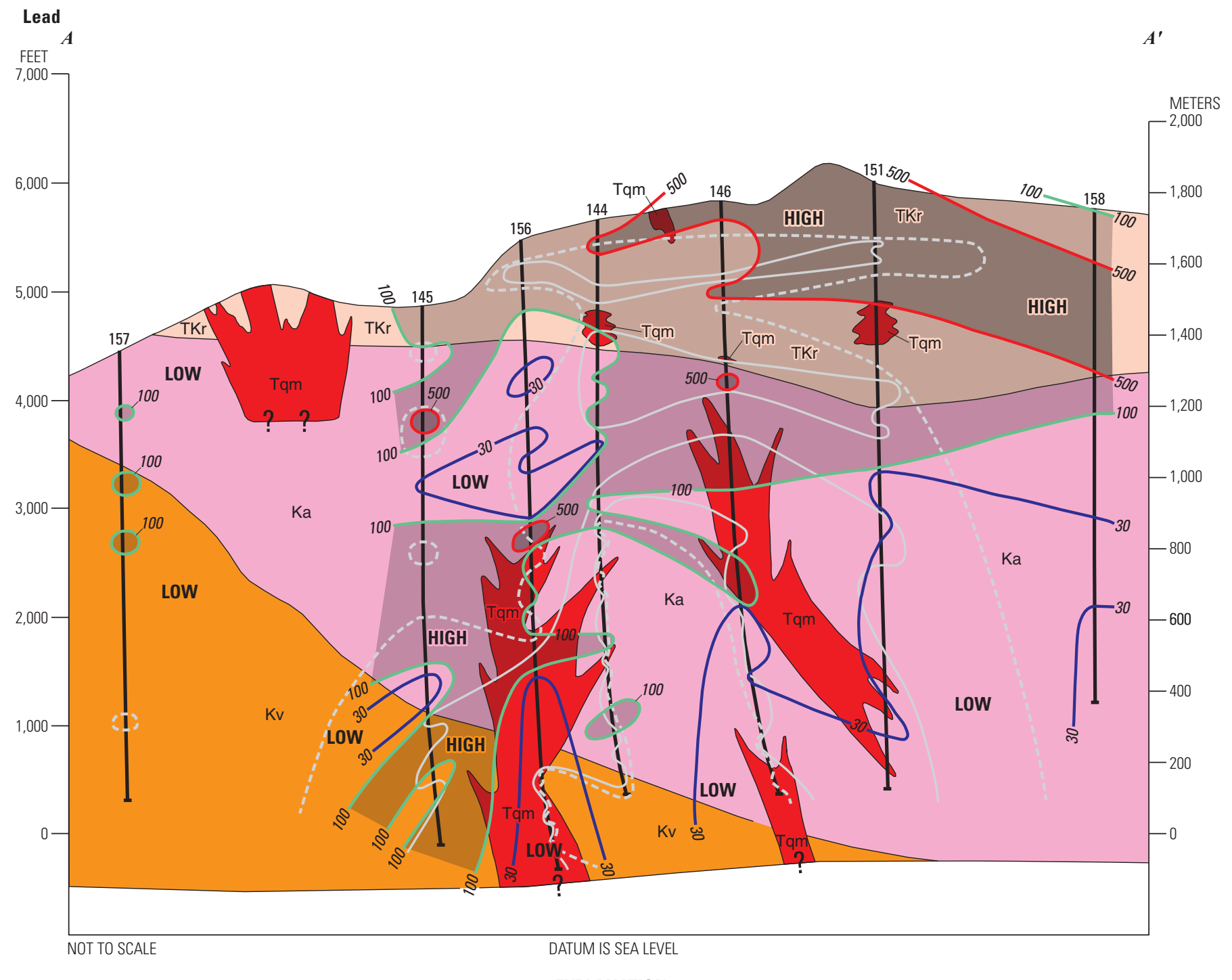

EXPLANATION

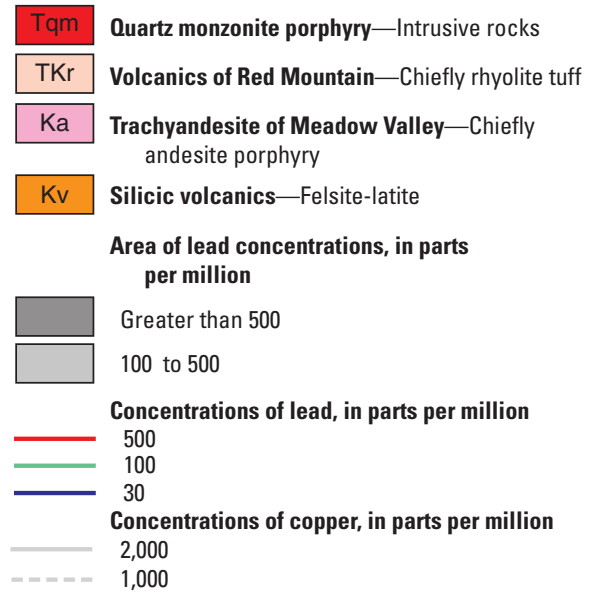

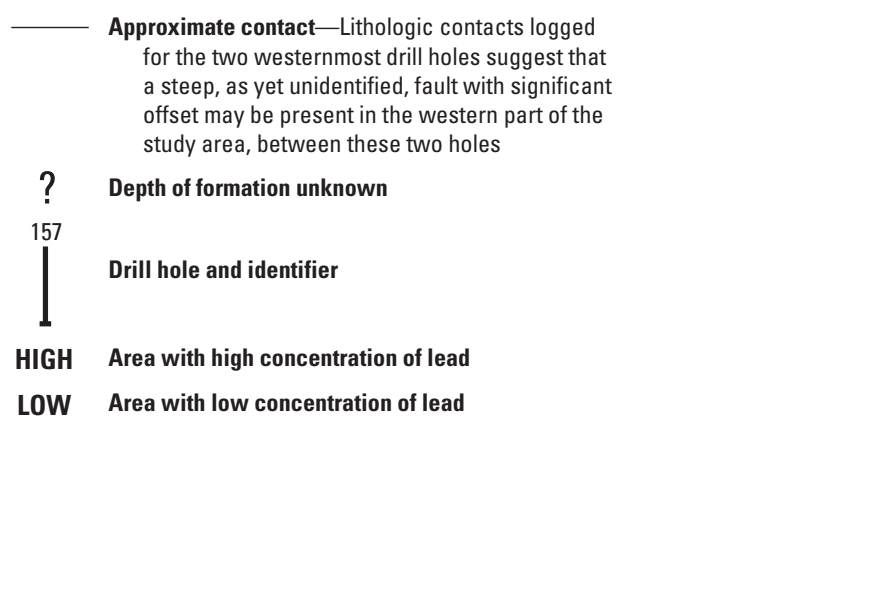

Figure 15. Distribution of lead in core samples. 


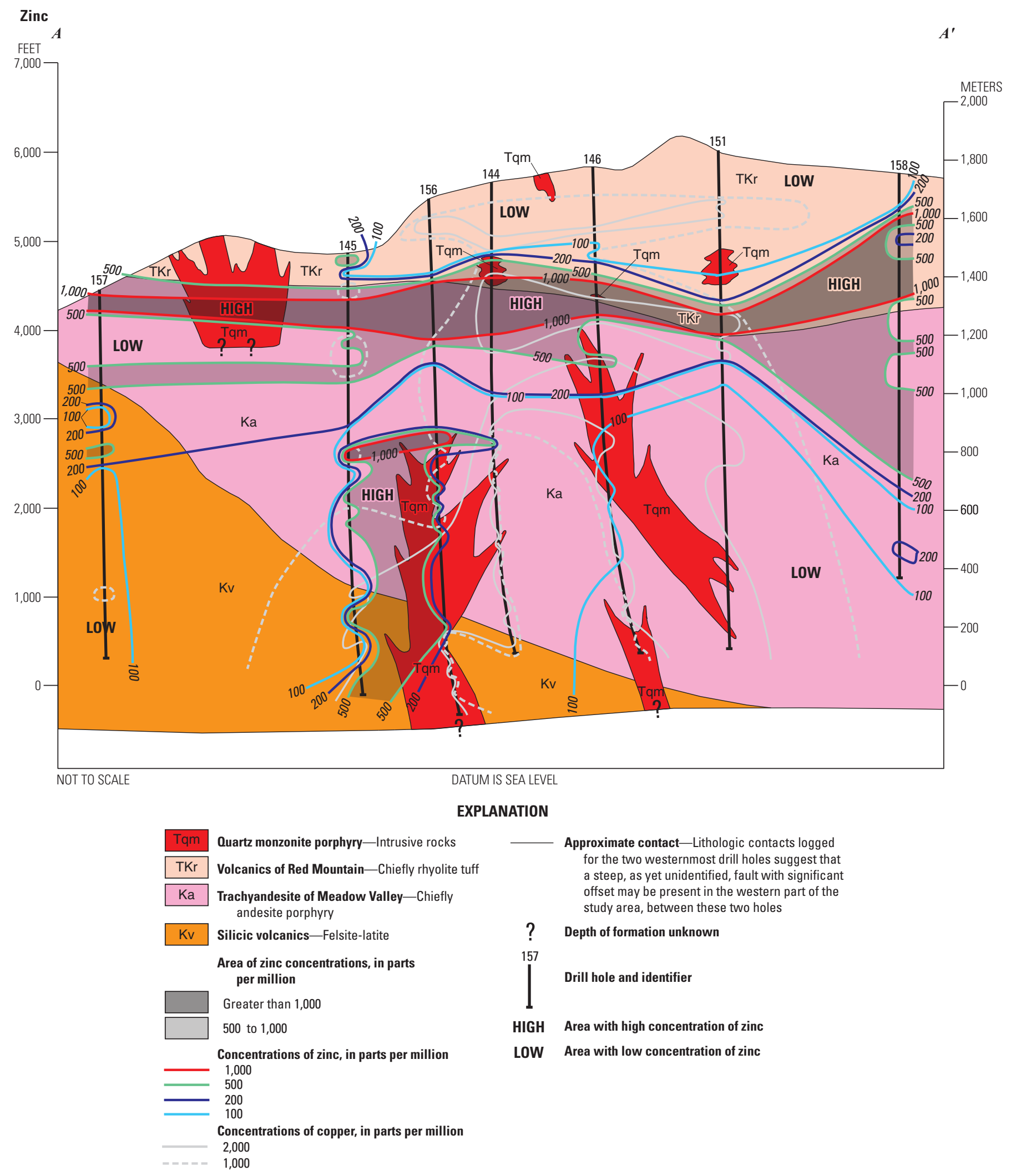

Figure 16. Distribution of zinc in core samples. 


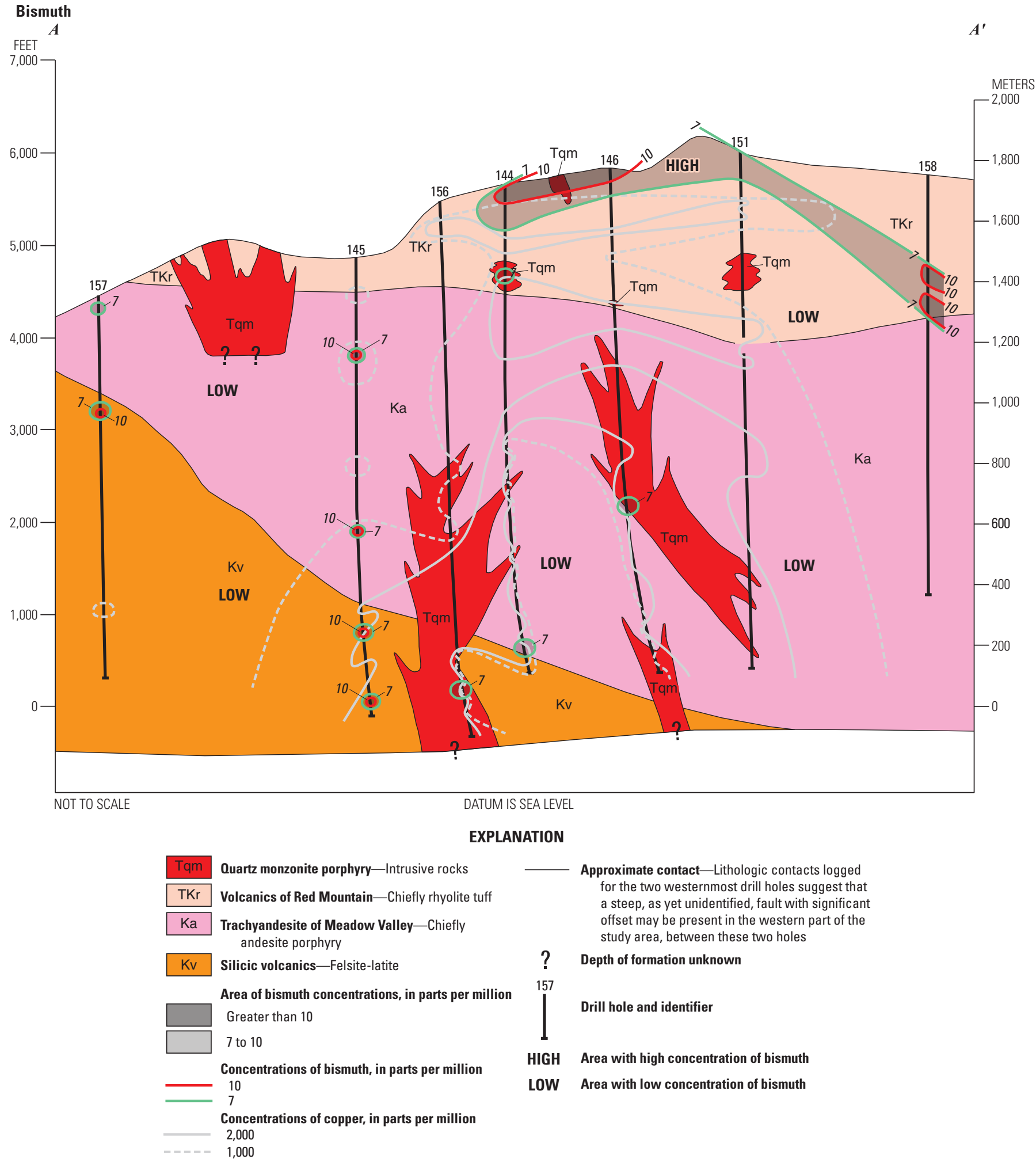

Figure 17. Distribution of bismuth in core samples. 


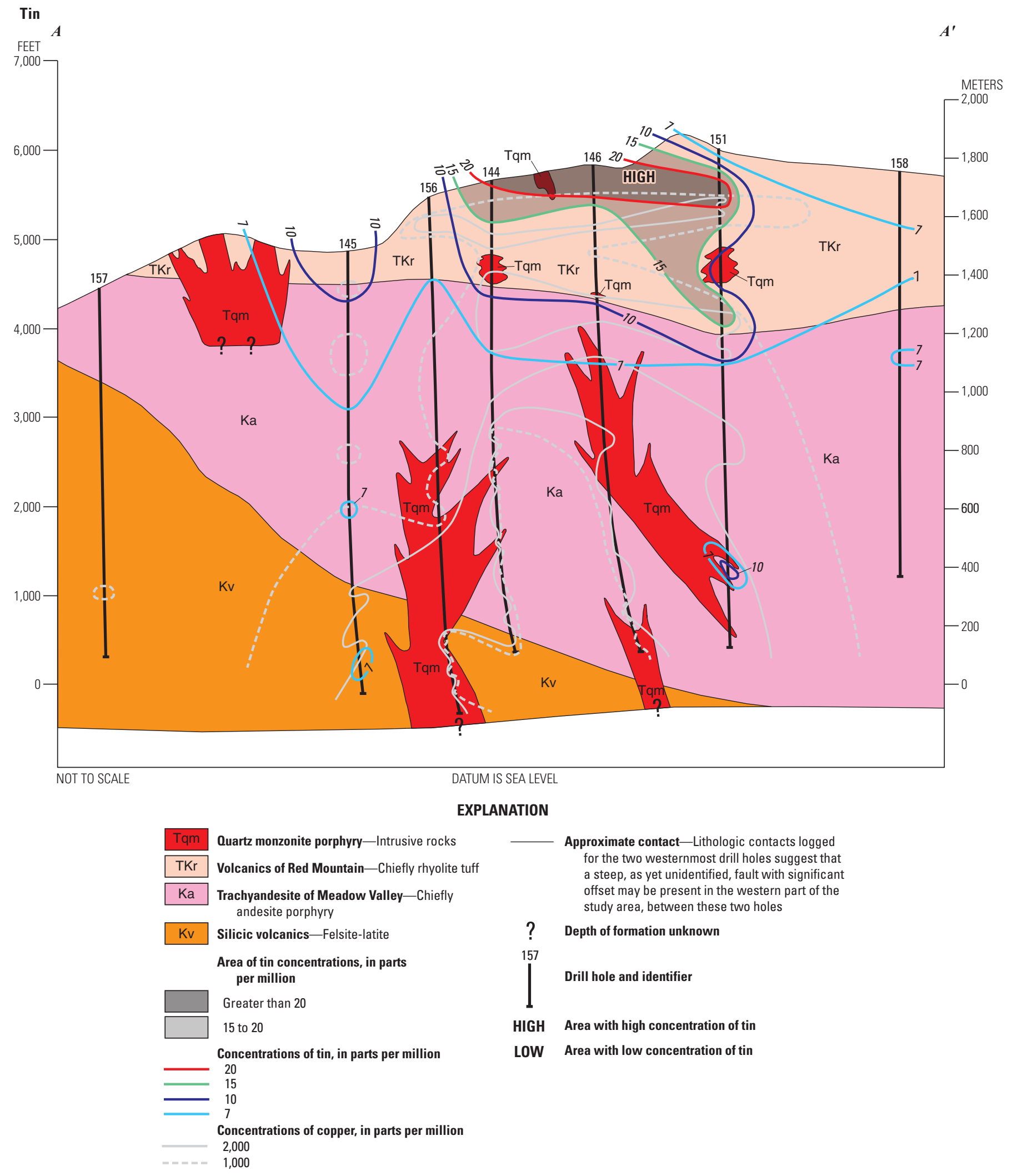

Figure 18. Distribution of tin in core samples. 


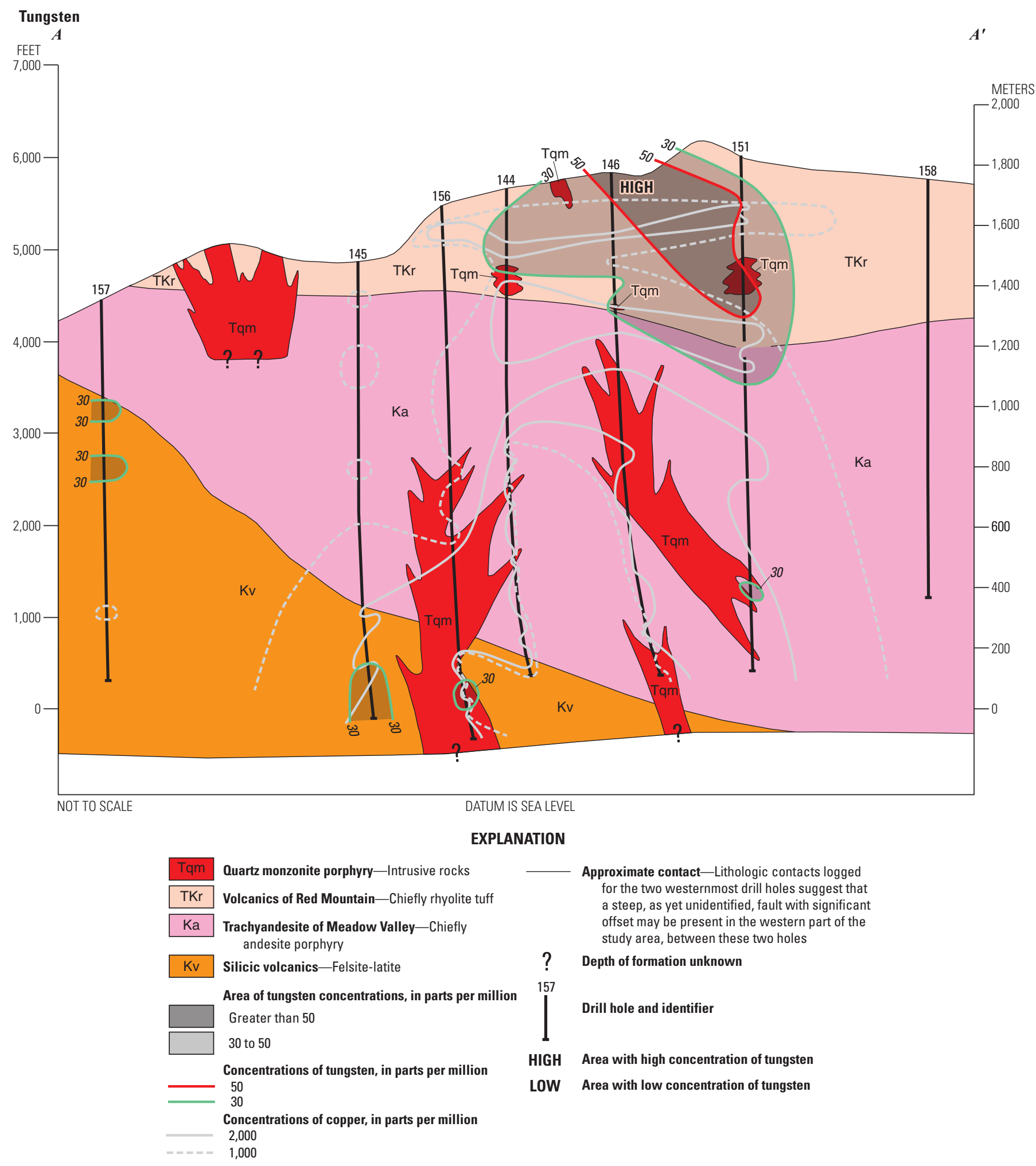

Figure 19. Distribution of tungsten in core samples. 


\section{Mainly Lithology- and Alteration-Related Elements and Minerals}

Selected elements in this group of mainly lithology- and alteration-related elements include $\mathrm{K}, \mathrm{Tl}, \mathrm{Co}, \mathrm{Ca}, \mathrm{Na}, \mathrm{Mn}, \mathrm{B}$, $\mathrm{U}$, and $\mathrm{Mg}$. Selected minerals include orthoclase, kaolinite and clay minerals, pyrophyllite, magnetite, pyrite, hematite, calcite, plagioclase, chlorite, quartz, and mica, as described in the succeeding paragraphs.

Potassium and Thallium.- The analytical ranges of potassium and thallium concentrations are limited compared to many of the other selected elements. As a consequence, it is difficult to contour concentrations of these two elements in any detail. The estimated threshold value for potassium is about 2.50 percent and for thallium is about $0.20 \mathrm{ppm}$ (table 2). The distributions of potassium and thallium are shown on figures 20 and 21, respectively. In both the deep and mid-level areas, most of the potassium is associated with orthoclase (fig. 22). Other potassium minerals include sericite, alunite, and jarosite, which are mostly present in the rhyolite tuff unit. Biotite, another potassium-rich mineral, is commonly accompanied with magnetite and is widely disseminated throughout the andesite unit, probably as a result of the early potassic alteration phase. These two minerals produce a distinct black color in drill core samples. In the deep part of the hypogene $\mathrm{Cu}$-Mo deposit, high concentrations ( $>3.00$ percent) of potassium coincide spatially with both limbs (fig. 5). Similar concentrations extend in an arcuate halo over the mid-level part of the deposit.

The high ( $>3.00$ percent) potassium concentrations in the westernmost drill hole 157 and in the bottom of adjacent hole 145 are related to higher overall potassium and orthoclase contents in the felsite-latite unit and not to the hypogene $\mathrm{Cu}-\mathrm{Mo}$ deposit.

Both potassium and thallium exhibit relatively low concentrations in the "barren" core area of the deposit. Thallium (fig. 21) exhibits weak concentrations (1-2 ppm) in the area of both limbs of the deep hypogene deposit, where it likely substitutes for potassium in orthoclase. Thallium is most highly concentrated $(>3 \mathrm{ppm})$ in a broad zone in the upper part of the system, with the highest concentrations found directly above the deep part of the hypogene deposit. The factor analysis for the hypogene dataset shows thallium associated with potassium (table 3 ), whereas thallium in the supergene dataset is associated with lead and other elements (table 3 ). Thallium is known to be hosted in lead minerals (Albuquerque and Shaw, 1972). In agreement with this observation, the thallium distribution in the upper part of the deposit is spatially similar to the zone containing high lead concentrations (fig. 15). In contrast to orthoclase, thallium, like lead, is concentrated at the present surface of the deposit, which is probably its original location. Thus, thallium has not been significantly mobilized as a result of supergene enrichment or weathering processes.
Orthoclase.-The highest orthoclase concentrations (50-unit contour line) (fig. 22) encompass areas that are closely associated with the quartz monzonite porphyry, and with areas with high concentrations of potassium and thallium (figs. 20 and 21). The 20-unit contours form an extensive halo peripheral to the areas of quartz monzonite porphyry, and mainly in the andesite unit. This distribution may define the general limit of the late-stage potassic alteration zone. Only relatively low concentrations ( $<20$-unit contour) of orthoclase are present in the "barren" core area of the hypogene $\mathrm{Cu}-\mathrm{Mo}$ deposit, where sodium and plagioclase concentrations are both relatively high. Orthoclase is found in relatively high concentrations ( $>20$-unit contour) in the felsite-latite unit. Both potassium and orthoclase are present in relatively low concentrations in the rhyolite tuff unit. The 10-unit contour for orthoclase in the andesite unit roughly defines the lower limit of supergene effects in this deposit. Above this line both premineralization and deposit-related orthoclase has been largely replaced by sericite, clay minerals, and alunite.

Kaolinite and Other Clay Minerals.-This category includes all clay minerals, with kaolinite being the dominant species. Only a few scattered, weak clay-related anomalies are present in the deep part of the system. In contrast, the rhyolite tuff unit exhibits relatively high concentrations $(>10$-unit contours) of clay minerals (fig. 23), which are thought to be primarily a product of advanced argillic alteration (Guilbert and Park, 1986). However, it is possible that the rhyolite tuff may have contained some pre-mineralization clay minerals. Clay minerals are generally absent in the near-surface area as a result of weathering during formation of the leached cap.

Pyrophyllite.-Pyrophyllite was detected by XRD analyses in only a few samples. However, it was easily identifiable in drill core by its appearance and greasy feel. This mineral is present in a distinct, nearly horizontal zone in the upper part of the deposit (fig. 24), which is almost entirely confined to the rhyolite tuff unit and is associated with the zone of advanced argillic alteration (Guilbert and Park, 1986). Pyrophyllite has also been destroyed near the surface as a result of weathering related to formation of the leached cap.

Magnetite and Biotite.-Figure 25 shows the upper limit of visible black biotite and XRD-determined magnetite and the distribution of magnetite. Both magnetite and biotite are found mostly in the andesite unit. The unaltered andesite unit is normally a medium to dark gray, whereas hydrothermally altered andesite is black because of a combination of high contents of magnetite and fine-grained biotite that are related to the early potassic alteration event (Quinlan, 1986; Lecumberri-Sanchez and others, 2013). The upper limit of this mineralogical boundary also marks the approximate depth of supergene enrichment. The deep zone of high ( $>10$-unit contour) magnetite concentrations roughly encompasses the area containing high concentrations for many of the elements associated with the hypogene $\mathrm{Cu}-\mathrm{Mo}$ deposit, including copper, silver, molybdenum, and sulfur. 


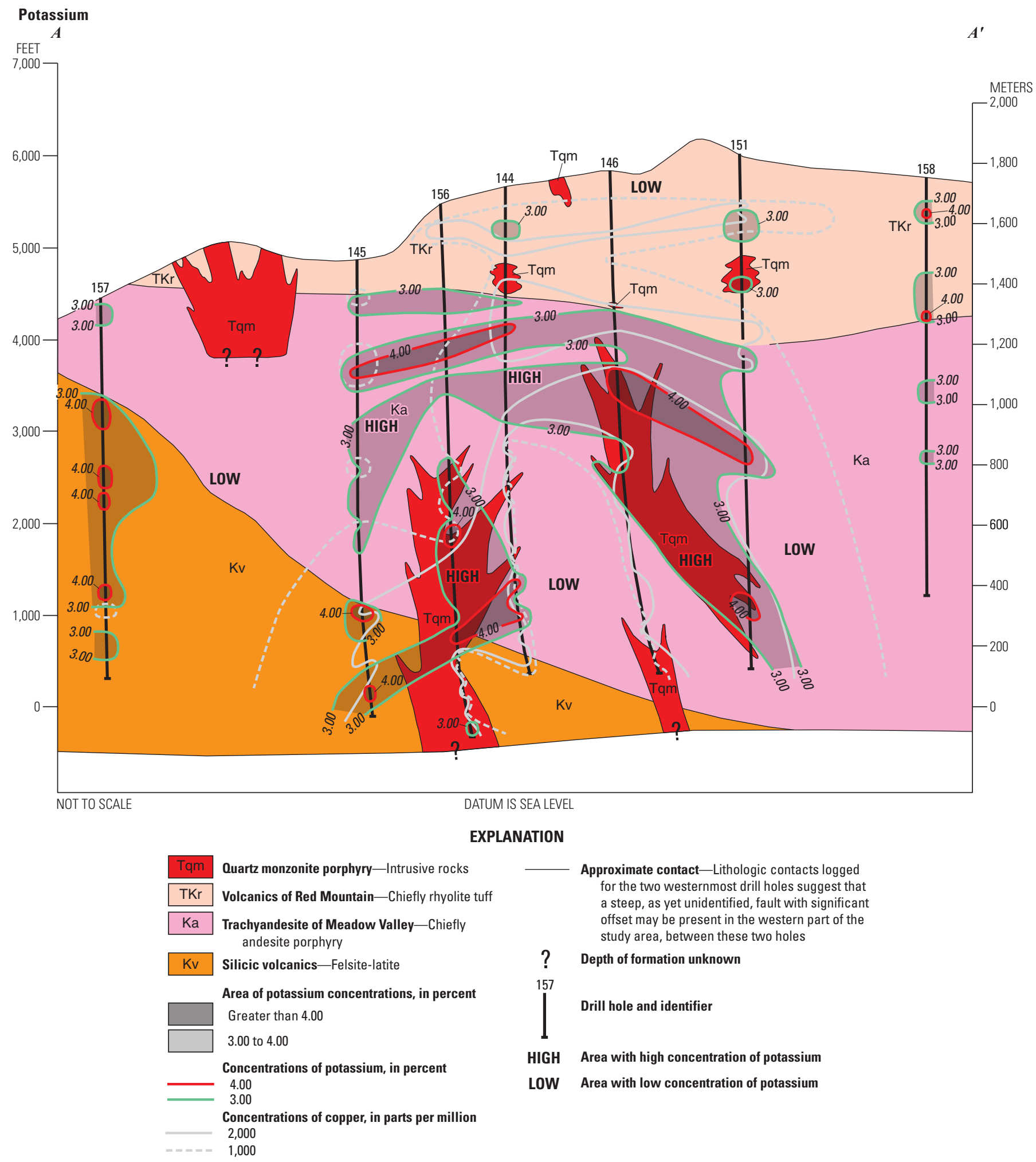

Figure 20. Distribution of potassium in core samples. 


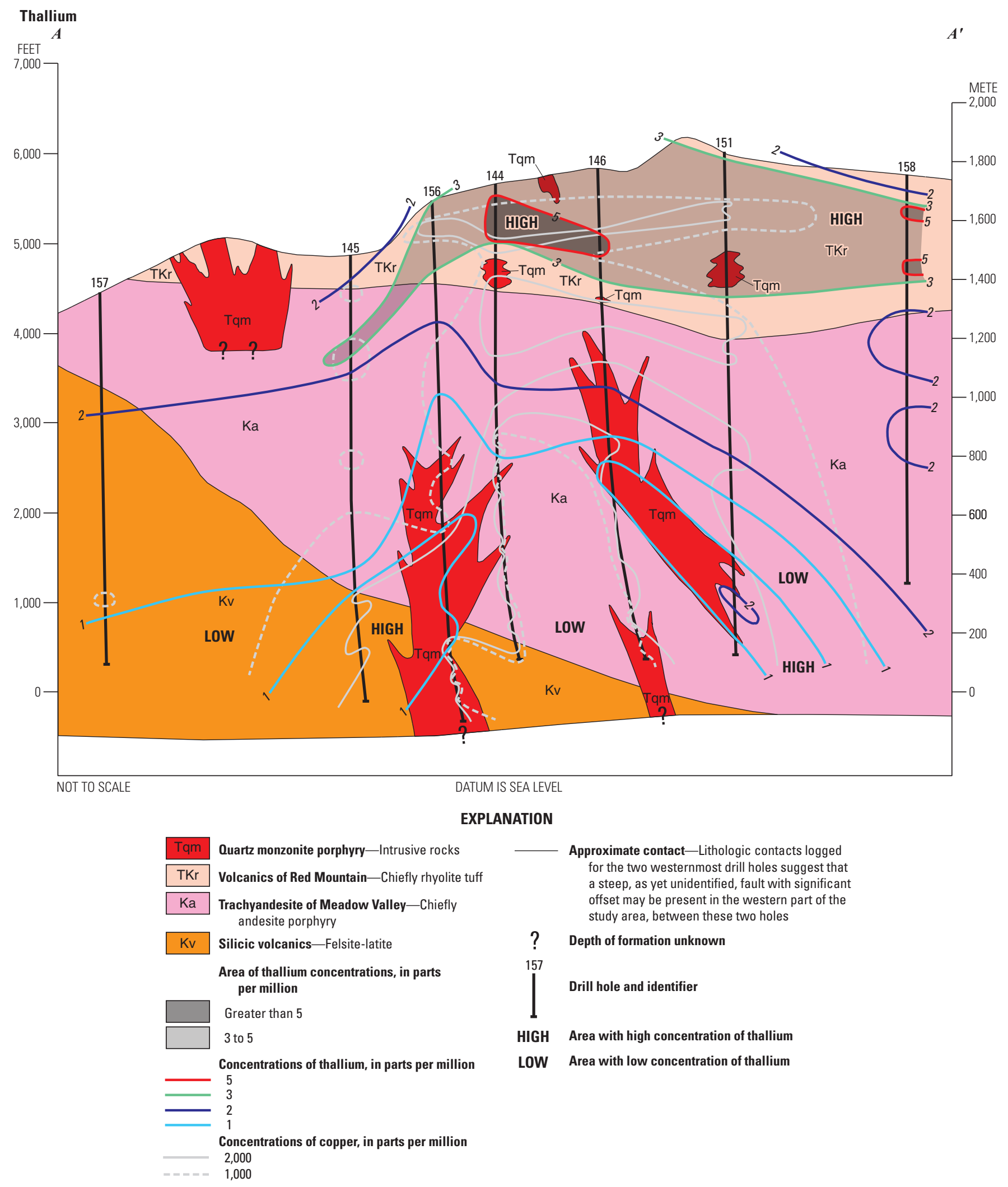

Figure 21. Distribution of thallium in core samples. 


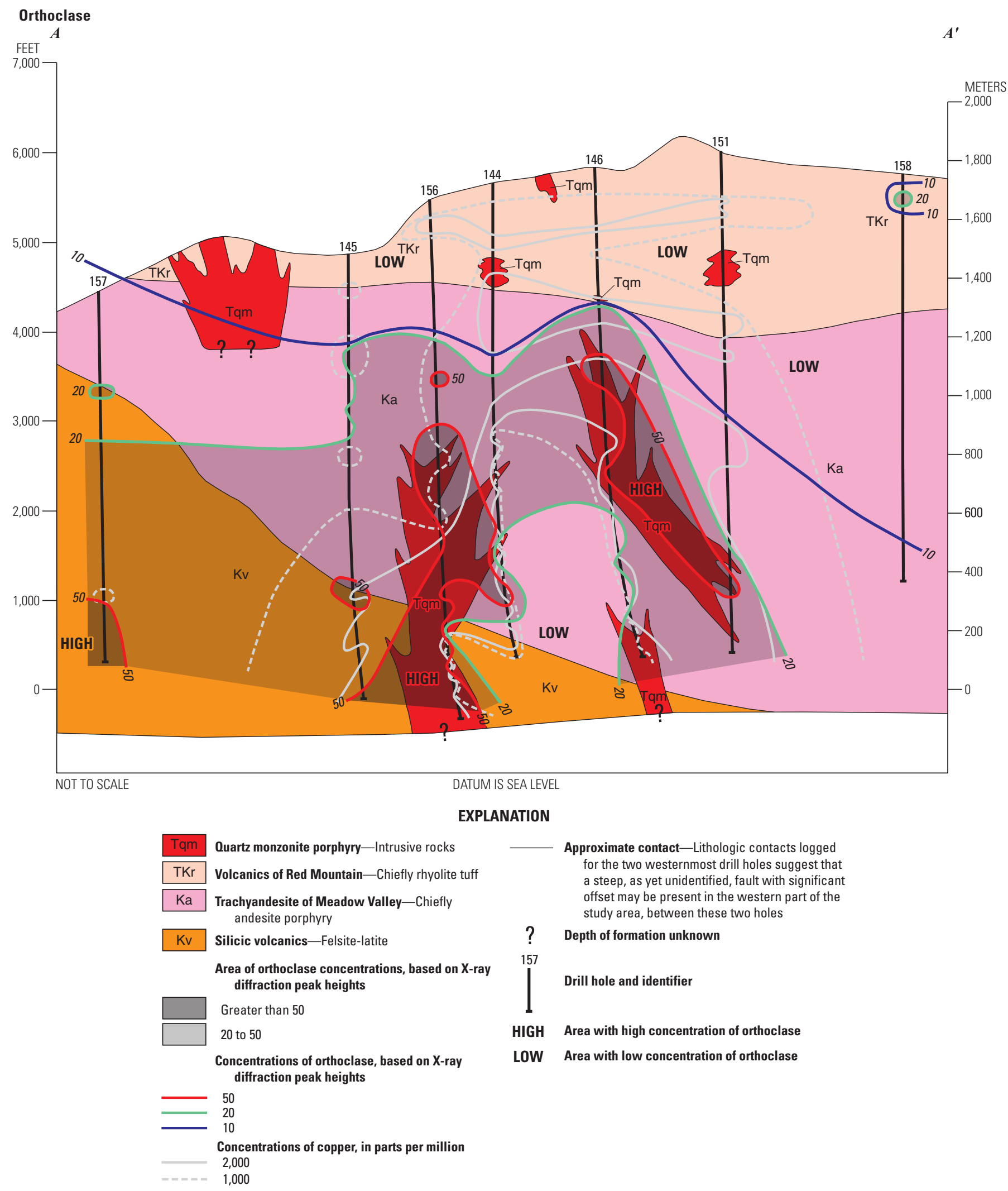

Figure 22. Distribution of orthoclase in core samples. 


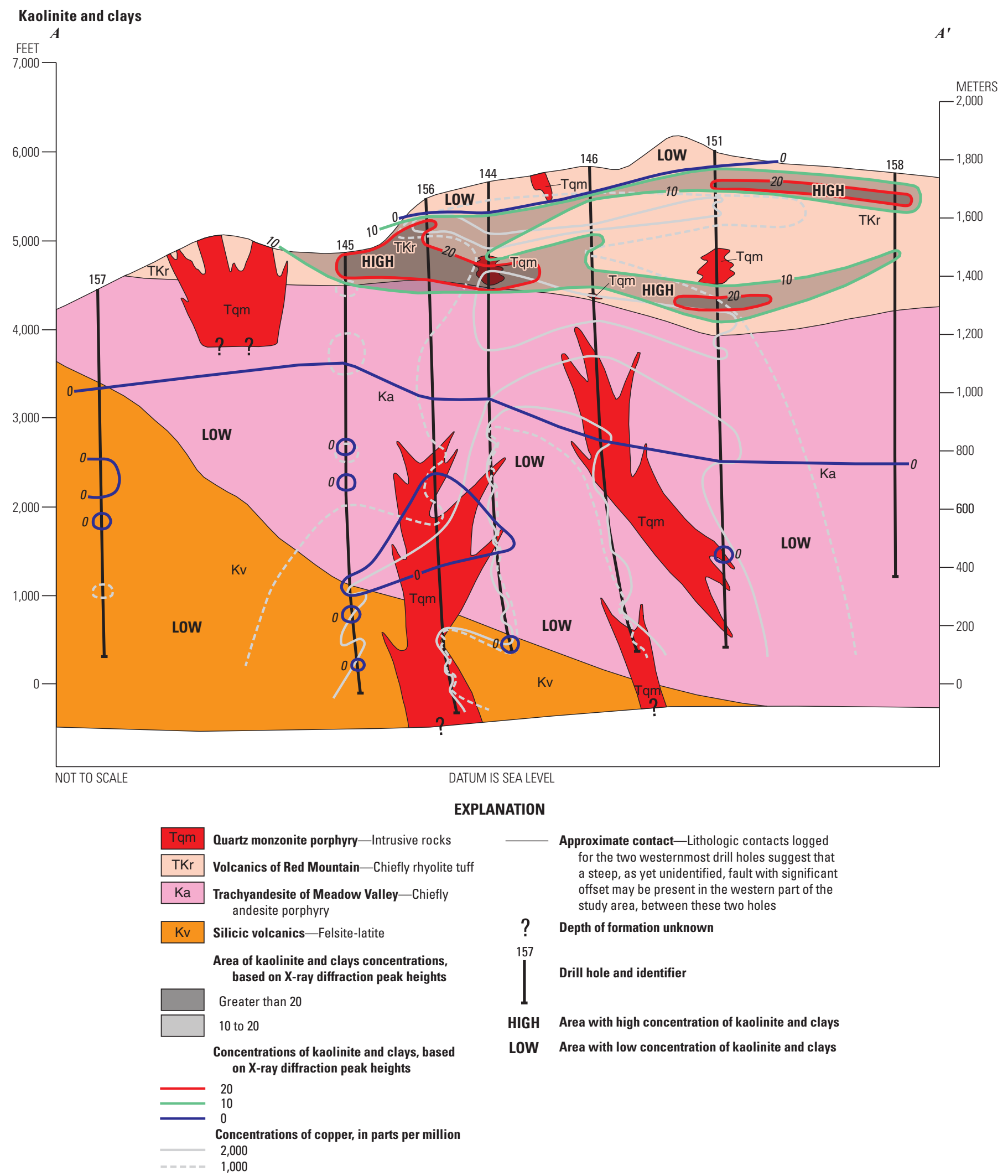

Figure 23. Distribution of kaolinite and other clay minerals in core samples. 


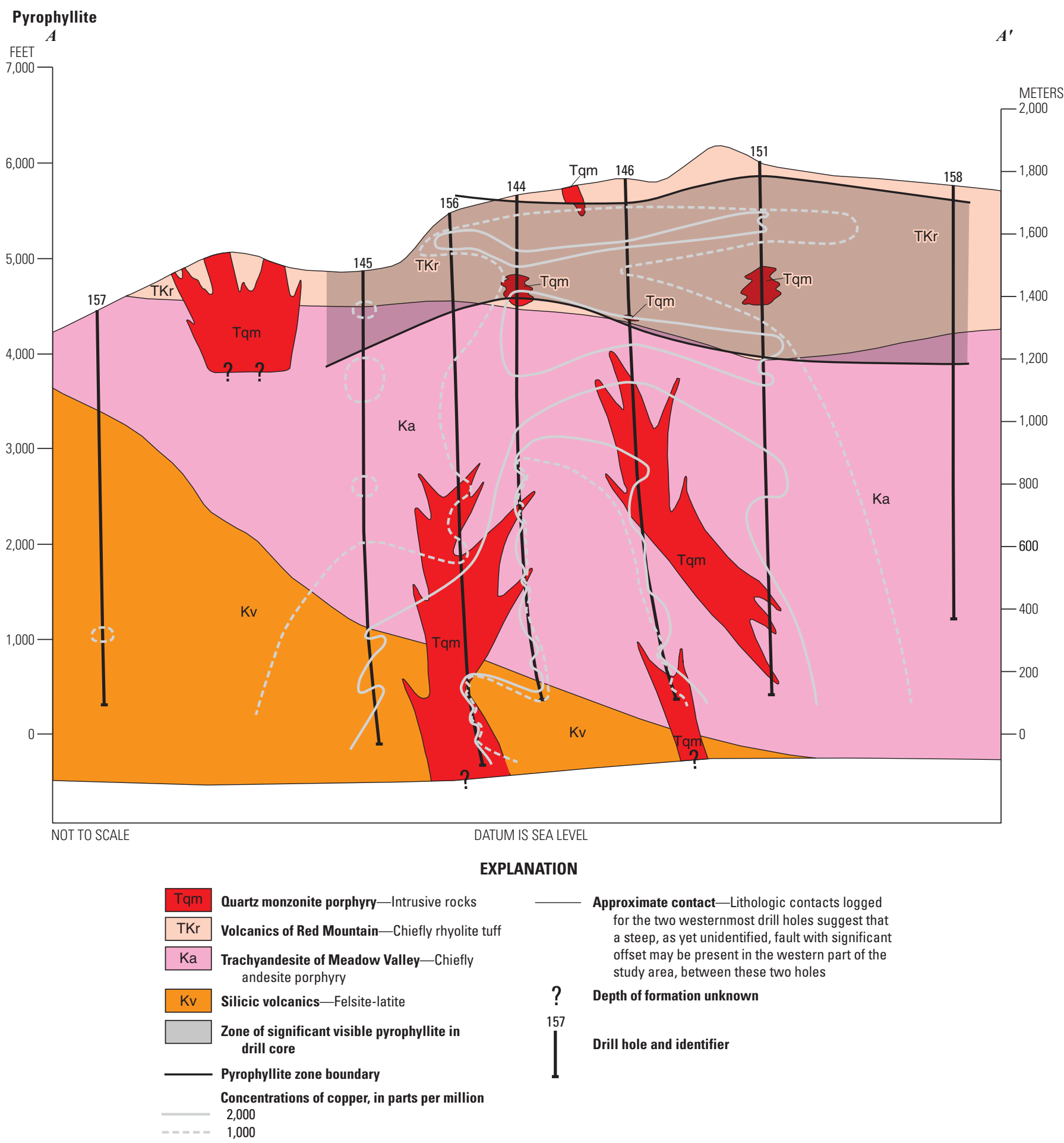

Figure 24. Distribution of pyrophyllite in core samples. 


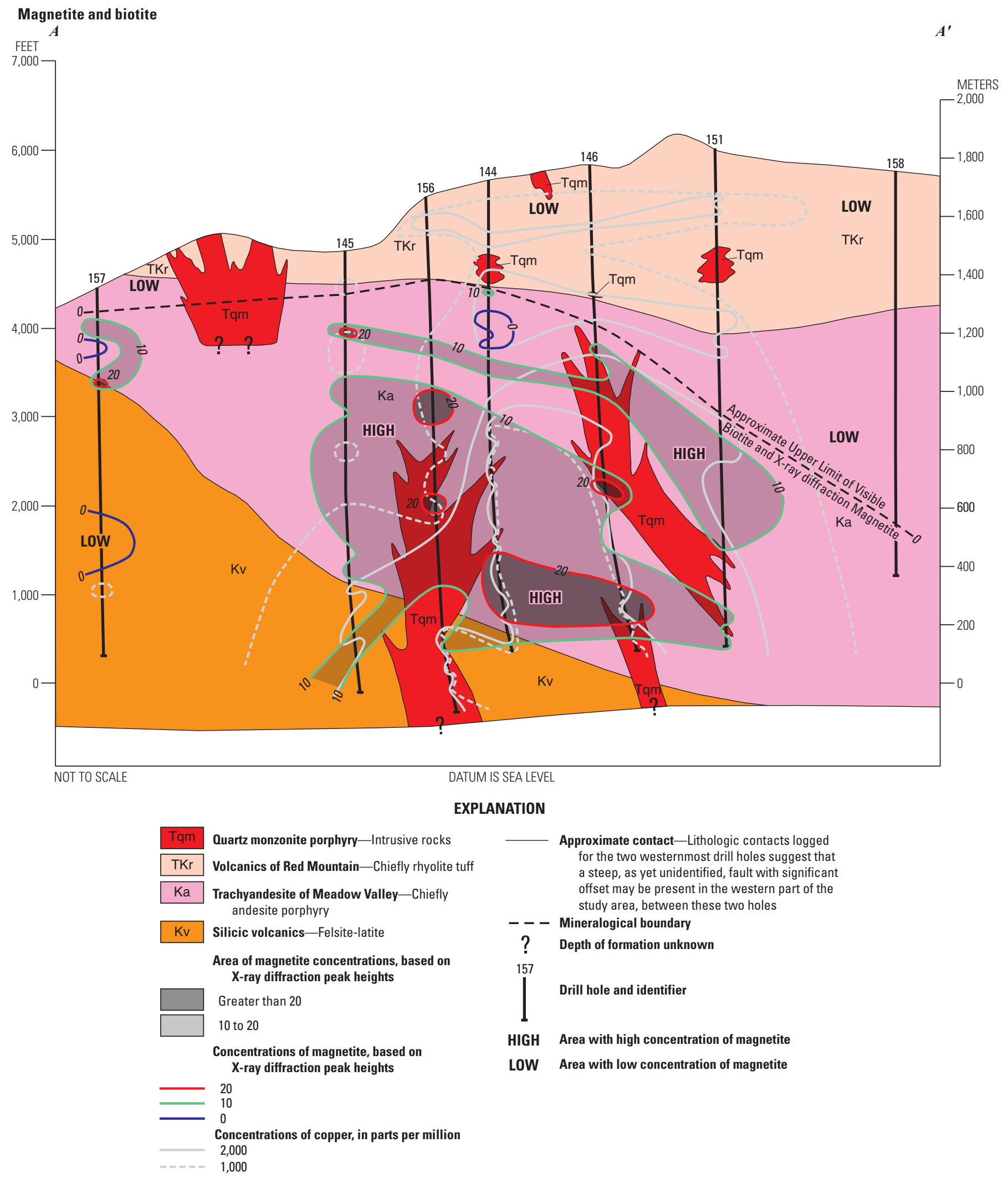

Figure 25. Distribution of magnetite and biotite in core samples. 
In contrast, however, magnetite concentrations are high (>20-unit contour) in the "barren" core zone of the deposit where many of the hypogene deposit-related elements exhibit relatively low concentrations as compared to the two limbs of the deposit.

Cobalt, Pyrite, and Hematite.-The estimated threshold value for cobalt is about 20-23 ppm (table 2). The distribution of cobalt (fig. 26) generally shows no clear pattern associated with the deep part of the hypogene $\mathrm{Cu}-\mathrm{Mo}$ deposit. Relatively low $(<20 \mathrm{ppm})$ concentrations seem to be spatially associated with quartz monzonite porphyry bodies.

In the area of the mid-level and deep parts of the hypogene deposit, pyrite (fig. 27) is present in an arcuate zone between the 5-and 10-unit contours that corresponds spatially with the 1,000-2,000 ppm copper zone (fig. 5). Pyrite concentrations are markedly higher in the upper part of the system, corroborating distributions noted in the drill core. This area of high pyrite concentrations is associated with the phyllic alteration zone. High concentrations (50-100 ppm) of cobalt form a broad zone, which correlates spatially with the distribution of high ( $>20$-unit contours) concentrations of pyrite, suggesting that cobalt proxies in pyrite. Additionally, the zone of near-surface low ( $<20 \mathrm{ppm}$ ) cobalt concentrations correlates spatially with low concentrations of pyrite and high concentrations of hematite (fig. 28). This near-surface zone likely represents the remnant of a leached cap that formed by circulation of oxidizing groundwater. During this process, cobalt was most likely leached and pyrite was oxidized to hematite, as observed in core and outcrop.

Calcium and Calcite.-The estimated threshold value for calcium in the andesite unit varies from 1.75 to 3.62 percent (table 2). The concentrations of calcium (fig. 29) are low $(<1.00$ percent) in the areas of the left (west) limb and the lowermost part of the right (east) limb of the hypogene $\mathrm{Cu}-\mathrm{Mo}$ deposit. This distribution reflects the relative loss of calcium (mainly because of the destruction of calcium-rich plagioclase) corresponding to a relative increase in potassium as orthoclase, particularly in the areas of the quartz monzonite porphyry. Higher in the system, in the upper part of the andesite unit, calcium concentrations decrease rapidly above the 1.00-percent calcium contour. This distribution indicates that calcium, which is highly mobile chemically, has been leached, especially above the 0.15 -percent contour, mostly during the time of supergene enrichment.

The approximate upper limit of calcite (identified by XRD) generally falls between the 0.70 - and 0.15 -percent calcium contours (fig. 29). The 0.05-percent calcium contour coincides closely with the base of XRD-identified alunite (fig. 8), a mineral mostly associated with advanced argillic alteration and the supergene zone (Guilbert and Park, 1986). The low $(<0.05$ percent) calcium concentrations in the rhyolite tuff unit probably result from a combination of (1) low pre-mineralization calcium concentrations, (2) later remobilization of this element associated with formation of the $\mathrm{Cu}-\mathrm{Mo}$ deposit, including supergene enrichment, and (3) later weathering.

The highest concentrations ( $>10$-unit contours) of calcite form an arcuate zone that is spatially associated with the deep hypogene deposit and with quartz monzonite porphyry bodies (fig. 30). Calcite is present in core samples in association with many of the hypogene deposit-related elements and minerals. Calcite is known to be associated with potassic alteration in PCDs (Guilbert and Park, 1986). The absence of calcite in the upper part of the section mostly reflects its destruction during supergene enrichment and subsequent weathering.

Sodium. - The estimated threshold value for sodium in the andesite unit is about 2.45 to 2.49 percent (table 2). Concentrations of sodium ( $>1.00$ percent) (fig. 31) form an arc centered on the deep part of the hypogene $\mathrm{Cu}-\mathrm{Mo}$ deposit. The highest sodium concentrations ( $>2.00$ percent) are present in the "barren" core area of the deposit between the limbs of the hypogene deposit. Although not verified petrographically, these high sodium concentrations may represent relatively high sodic plagioclase concentrations in the "barren" core of the hypogene deposit (fig. 5), where potassium metasomatism has not replaced the plagioclase of the host andesite unit. The 0.50 -percent sodium contour at the mid-level of the section roughly defines the base of the supergene zone in the andesite unit.

Plagioclase. - The highest ( $>50$-unit contour) plagioclase concentrations are in the area of the "barren" core and left (west) limb of the deep part of the deposit. High concentrations ( $>20$-unit contours) of plagioclase (fig. 32) define an area in the andesite unit that is spatially similar to that of the deep and mid-level parts of the hypogene $\mathrm{Cu}-\mathrm{Mo}$ deposit, indicating that plagioclase has not been hydrothermally altered totally to orthoclase, sericite, or other minerals. This zone coincides roughly with that of high sodium concentrations (fig. 31), suggesting the presence of sodic plagioclase in that area. Like sodium, plagioclase exhibits relatively low concentrations in the upper part of the andesite unit and in the rhyolite tuff unit. As was the case for cobalt and pyrite (figs. 26 and 27), as well as other elements and minerals, plagioclase is absent in the near-surface area where it has been destroyed as a result of weathering that formed the leached cap, as defined by the distribution of hematite (fig. 28).

Manganese. - The estimated threshold value for manganese in the andesite unit varies from 500 to $826 \mathrm{ppm}$ (table 2). Manganese shows relatively low concentrations $(<500 \mathrm{ppm})$ at depth in the area of both limbs of the hypogene deposit that are probably related mostly to the bulk chemistry of the quartz monzonite porphyry (fig. 33). In agreement with the calculated threshold value for the andesite unit, manganese concentrations are relatively high $(>500 \mathrm{ppm})$ in much of this formation and are mostly in the 500-1,000 ppm 


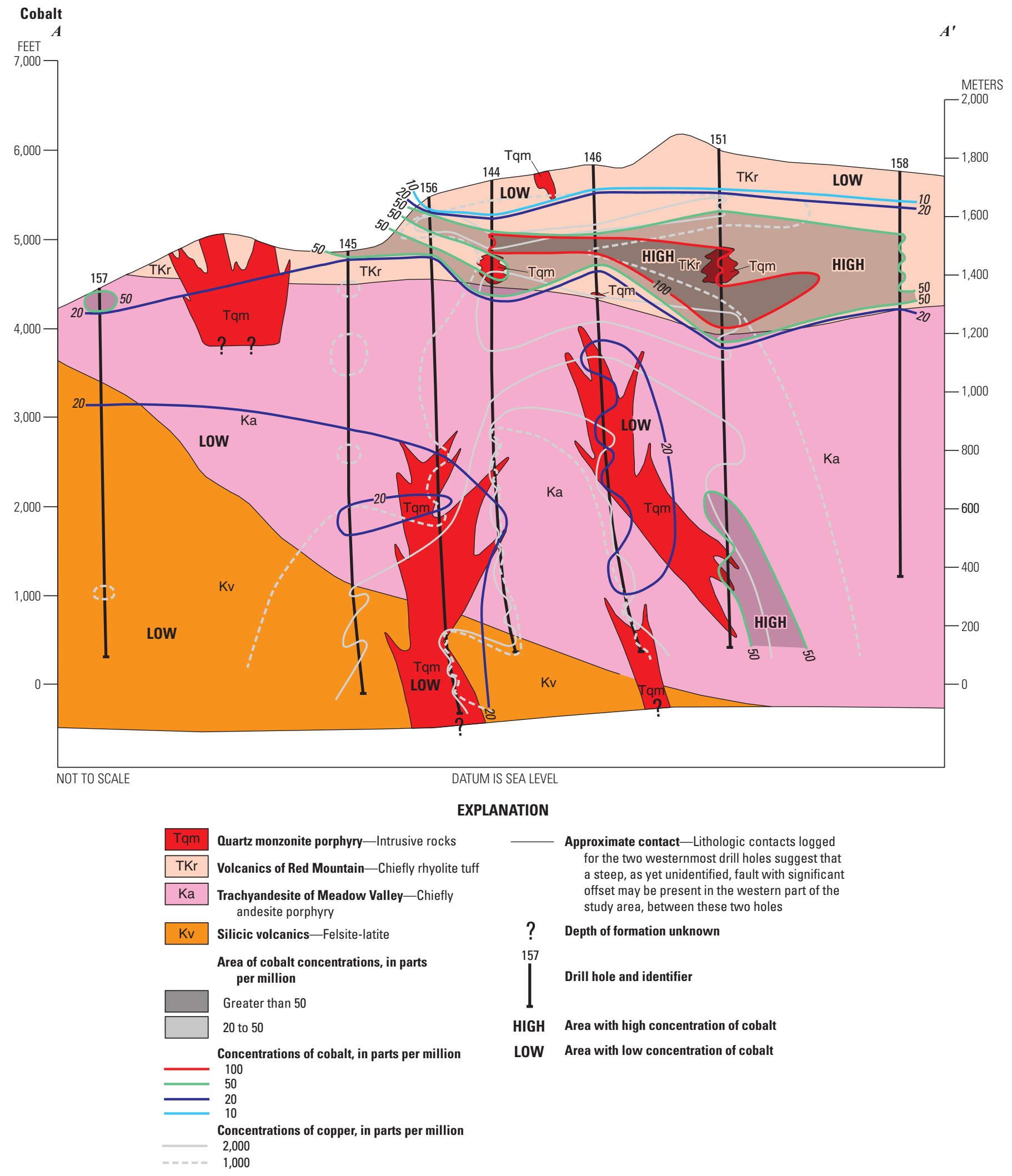

Figure 26. Distribution of cobalt in core samples. 


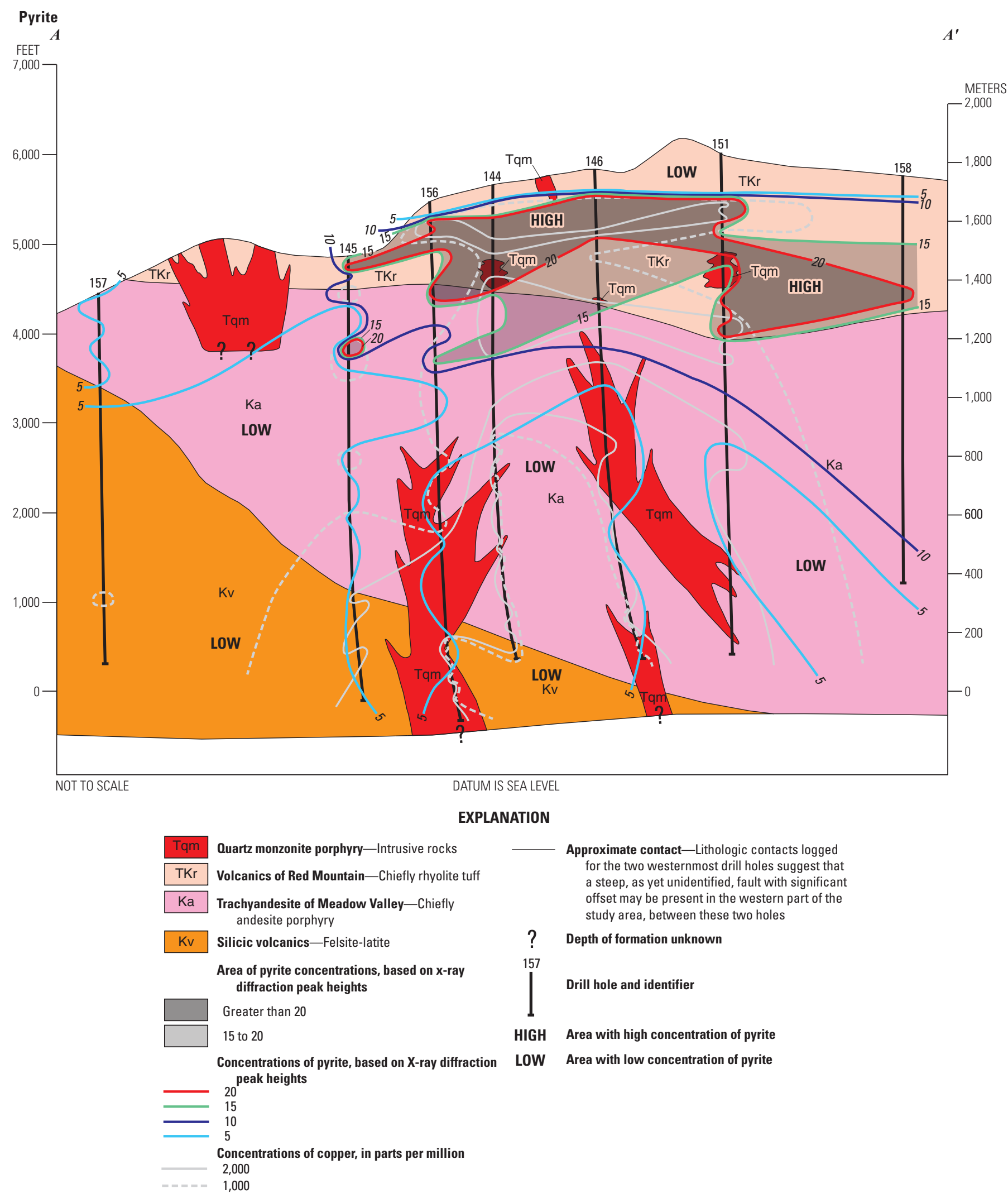

Figure 27. Distribution of pyrite in core samples. 


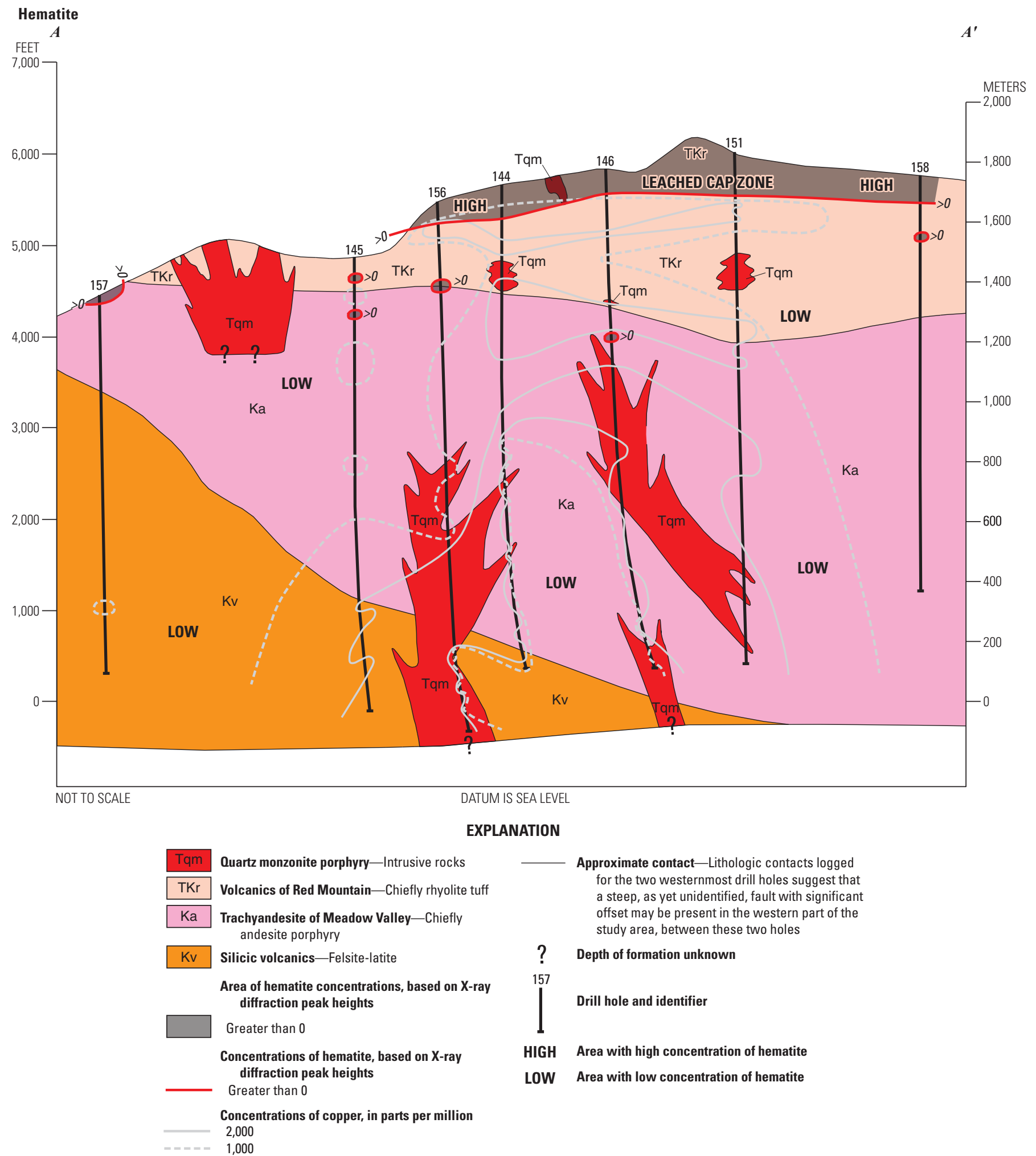

Figure 28. Distribution of hematite in core samples. 


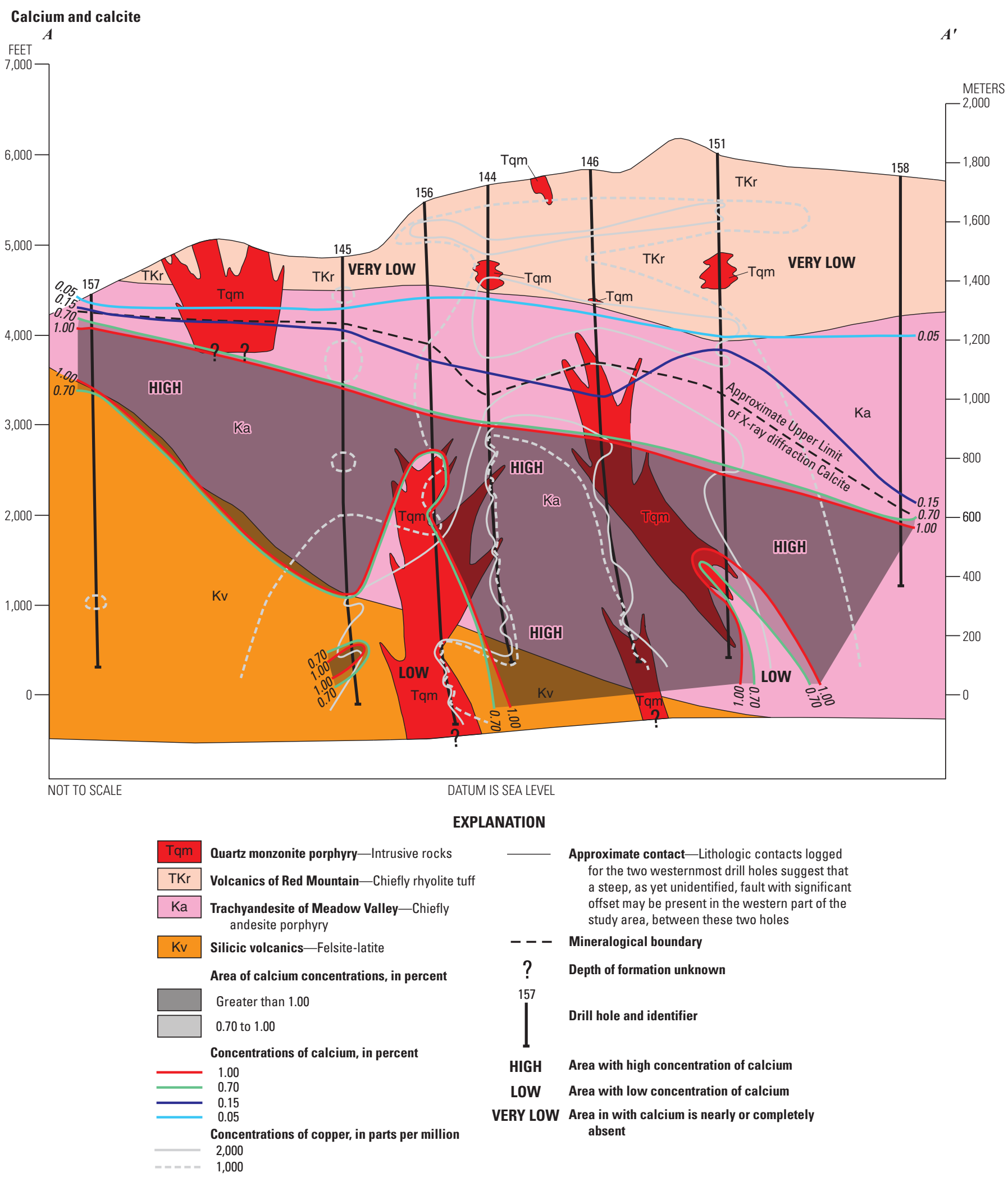

Figure 29. Distributions of calcium and calcite in core samples. 


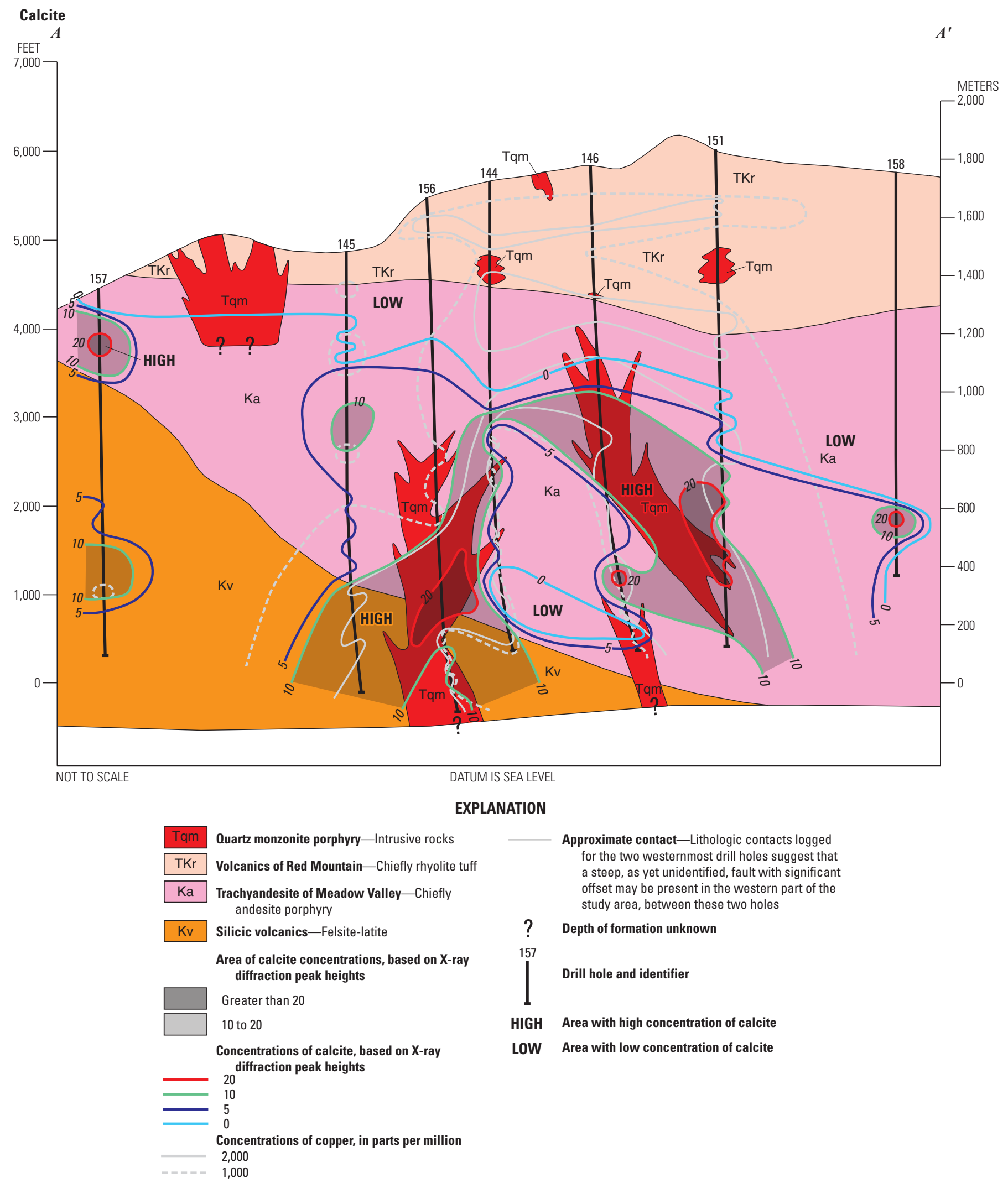

Figure 30. Distribution of calcite in core samples. 


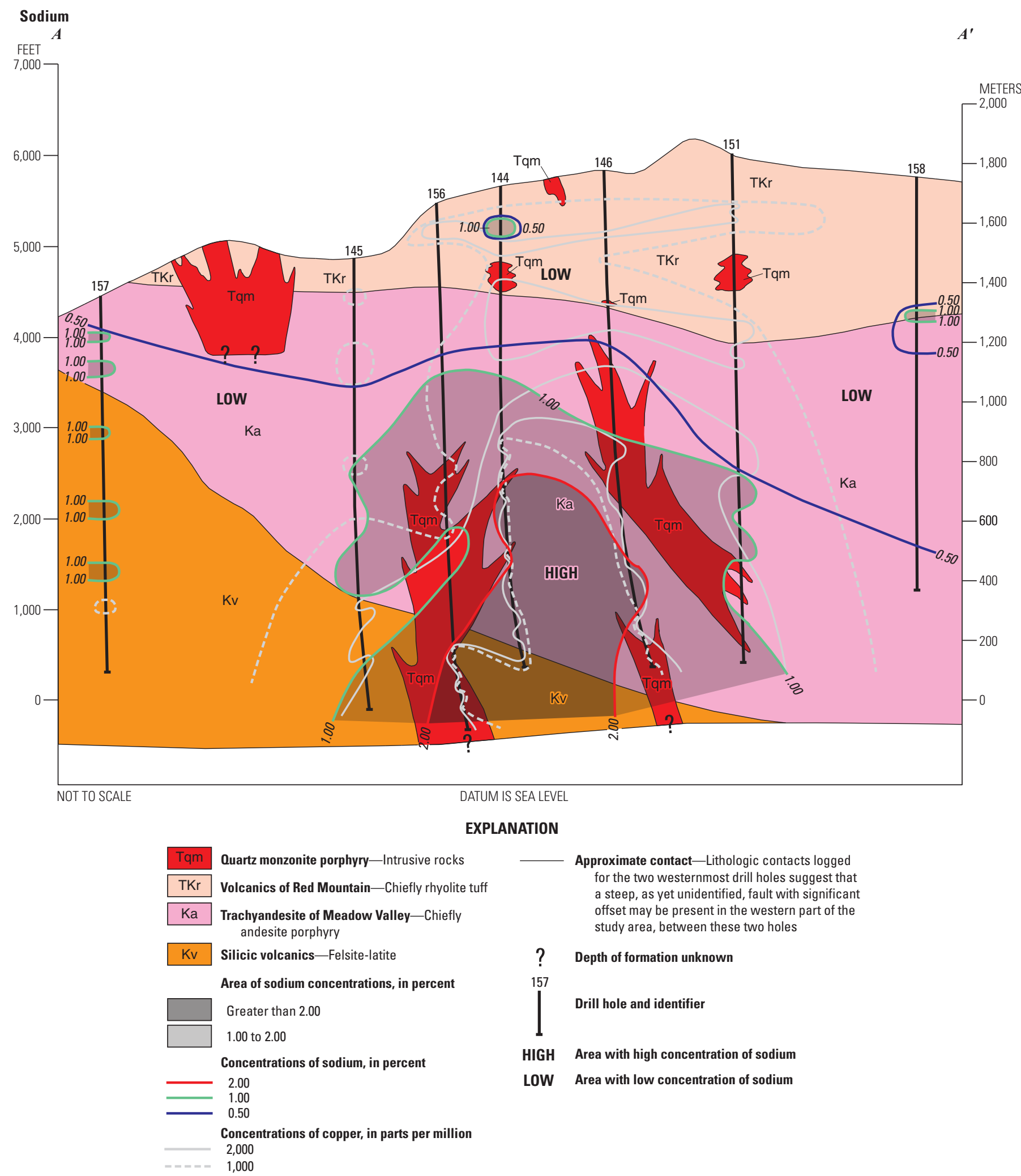

Figure 31. Distribution of sodium in core samples. 


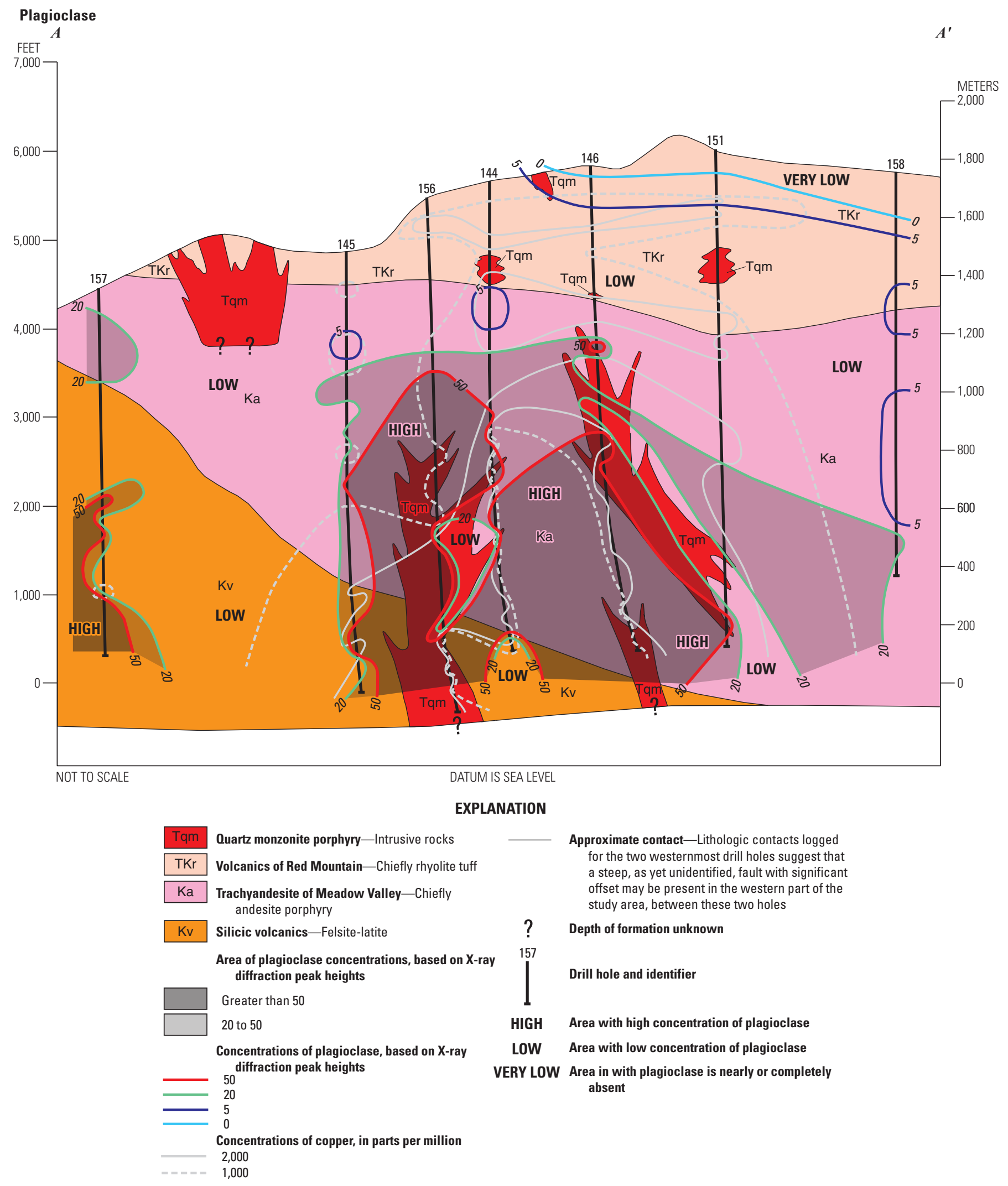

Figure 32. Distribution of plagioclase in core samples. 


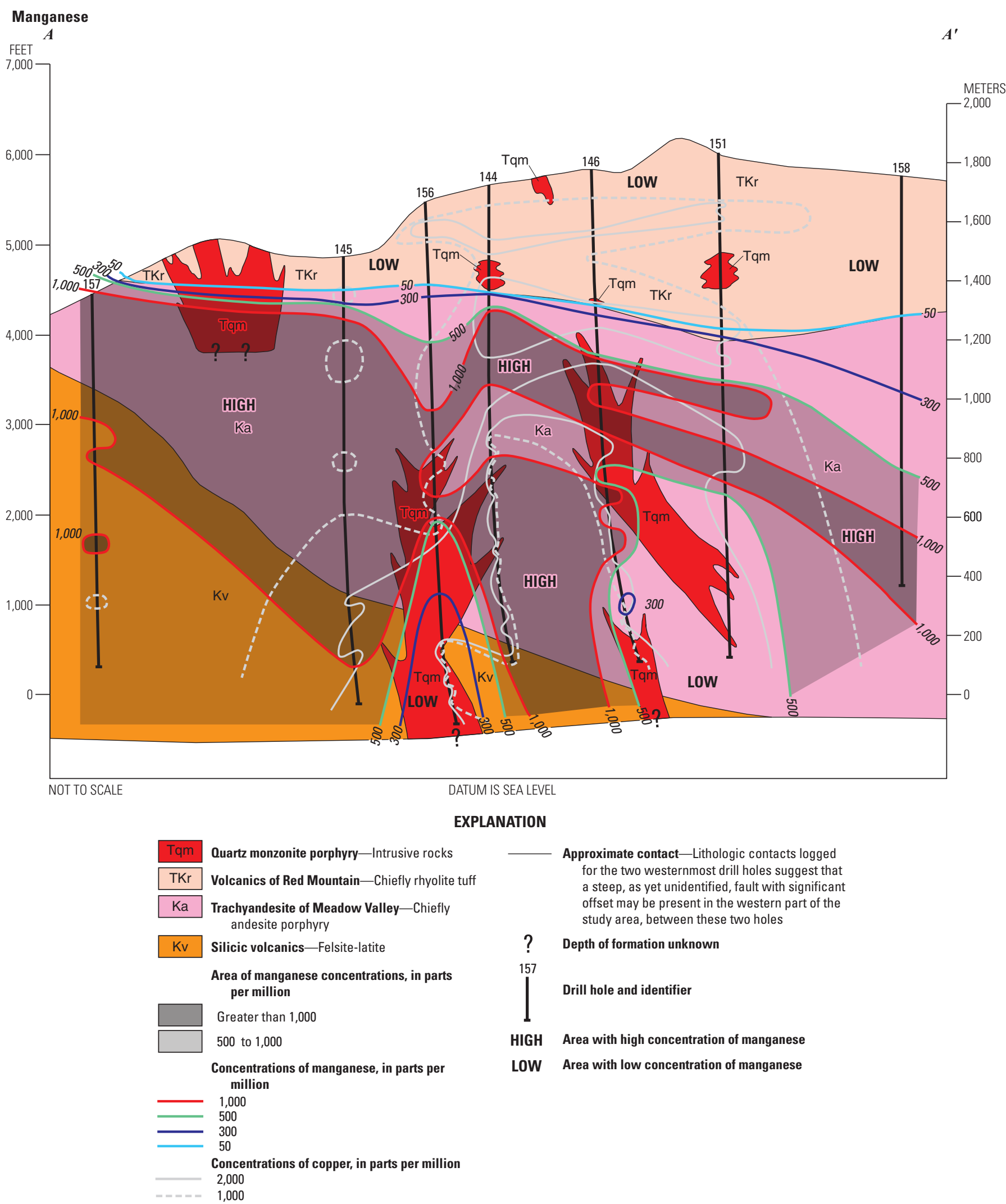

Figure 33. Distribution of manganese in core samples. 
range in the felsite-latite unit, irrespective of the distribution of elements related to the $\mathrm{Cu}-\mathrm{Mo}$ deposit. In contrast to the concentrations of manganese in these two units, the overall manganese concentration in the entire area of the rhyolite tuff unit is consistently below $50 \mathrm{ppm}$. The coincidence of this sharp change in concentration at the rhyolite tuff-andesite contact indicates that the contrasting manganese contents of these two formations are related mostly to their differences in bulk chemistry. The 500-ppm manganese contour near the top of the andesite unit is thought to locally approximate the base of the zone of supergene enrichment.

Boron.-The estimated threshold value for boron in the andesite unit is $15 \mathrm{ppm}$ (table 2). Relatively high concentrations (30-50 ppm) of boron (fig. 34) are present at depth in the area of the left (west) limb of the hypogene deposit, where arsenic, antimony, mercury, and other elements are also concentrated. Boron is most highly concentrated $(50->100 \mathrm{ppm})$ in the general area of the rhyolite tuff unit, where it is thought to be related to a combination of the bulk chemistry of the rhyolite tuff lithology as well as to deposit-related tourmaline. Boron is also known to occur in micas such as sericite (Harder, 1974). The high concentrations of boron near the present surface of the deposit area imply that boron is relatively immobile chemically in that area.

Uranium. - Cox (1986) notes that weak uranium anomalies are sometimes present in PCDs. The estimated threshold value for uranium is $1.9 \mathrm{ppm}$ (table 2). The concentrations of uranium are relatively high (>2 ppm) in the area of the left (west) limb of the hypogene deposit (fig. 35). An area with high uranium concentrations $(1->3 \mathrm{ppm})$ is also present in the rhyolite tuff unit. This area of high concentrations suggests that uranium either was locally highly concentrated in the pre-mineralization rhyolite tuff unit, or was mobilized and concentrated in this area, probably as a result of supergene enrichment and possibly later weathering.

Magnesium and Chlorite.- The estimated threshold value for magnesium in the andesite ranges from 1.25 to 2.23 percent (table 2). Most magnesium concentrations in the area of the section are below the threshold value. Magnesium concentrations and those of chlorite are largely determined by the contrasting chemistry of the andesite, felsite-latite, and rhyolite tuff units. The highest magnesium concentrations $(>0.70$ percent $)$ are found in the andesite unit; lower concentrations $(<0.50$ percent $)$ are associated with the rhyolite tuff and felsite-latite units, and locally, with the quartz monzonite porphyry (fig. 36). In the near-surface part of the deposit, magnesium, like cobalt, has clearly been removed during formation of the leached cap, probably as a result of circulation of oxidizing acidic groundwater.
Similarly, chlorite is concentrated ( $>4$-unit contours) throughout most of the andesite unit (fig. 37), exhibits lower concentrations ( $<4$-unit contours) in the felsite-latite unit, and is in less than detectable concentrations or totally absent in the rhyolite tuff unit. Thus, the presence or absence of chlorite can generally be used to define the andesite-rhyolite tuff boundary. Examination of core samples indicates that the high (>7-unit contours) chlorite concentrations on the right (eastern) side of the section formed mostly from biotite that was altered to chlorite during the supergene enrichment event. However, chlorite distributions in the overall area of this section also suggest a peripheral propylitic alteration zone related to the hypogene $\mathrm{Cu}-\mathrm{Mo}$ deposit. Typical propylitic alteration, which may or may not be related to the mineral deposit, is exposed locally in andesite outcrops on the eastern side of Red Mountain (Kistner, 1984) and is present regionally in scattered outcrops of this unit.

Quartz.-The distribution of quartz is hard to interpret because this mineral occurs in many forms with different ages, including forms that are related to pre-deposit host-rock chemistry and other forms that are related to hydrothermal events. Examination of drill core indicates that disseminated pre-mineral deposit quartz is present in the rhyolite tuff and felsite-latite units (fig. 38). Abundant quartz (>30-unit contour) is spatially related to the quartz monzonite porphyry. Core samples clearly show abundant, hydrothermally related, complex crosscutting quartz veins with and without various sulfide and other minerals. Non-vein, hydrothermal, disseminated silicification is also common. The highest ( $>60$-unit contour) quartz concentrations are mostly found in the rhyolite tuff unit in the central, near-surface part of the section, where the quartz is a combination of a non-vein quartz-rich lithology and superimposed hydrothermal quartz veins related to the hypogene $\mathrm{Cu}-\mathrm{Mo}$ deposit. Quartz veins are also present in the most altered outcrops on Red Mountain.

Muscovite (Sericite).-Muscovite mica (determined by XRD) at Red Mountain is predominantly sericite. A welldefined peripheral arcuate zone of high ( $>15$-unit contour) mica concentrations is present above the deep part of the hypogene $\mathrm{Cu}-\mathrm{Mo}$ deposit (fig. 39). This zone of sericite defines pervasive phyllic alteration. The lack of mica concentrations in the near surface reflects the destructive effects of weathering in the leached cap area as defined by the distribution of hematite (fig. 28). 


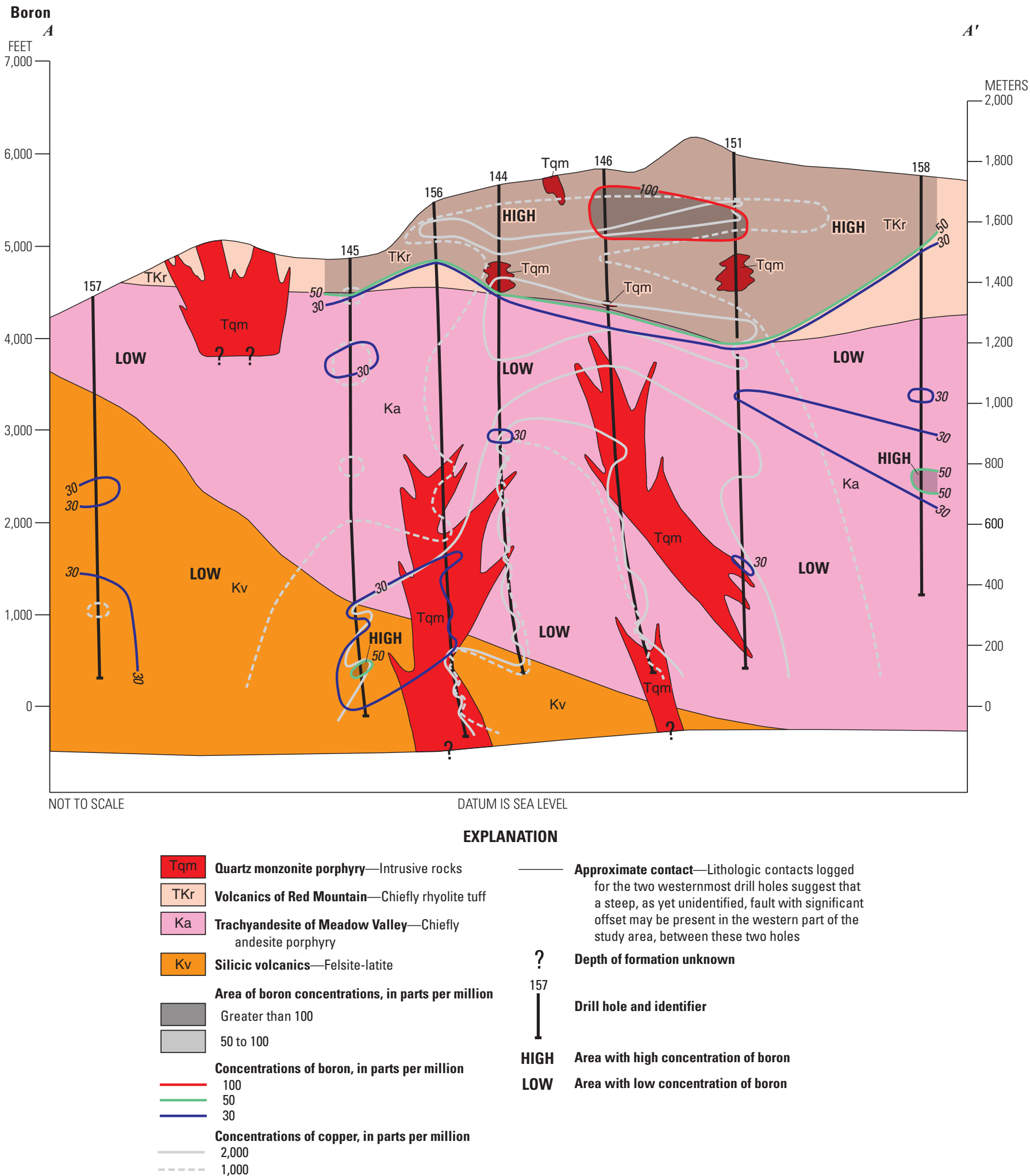

Figure 34. Distribution of boron in core samples. 


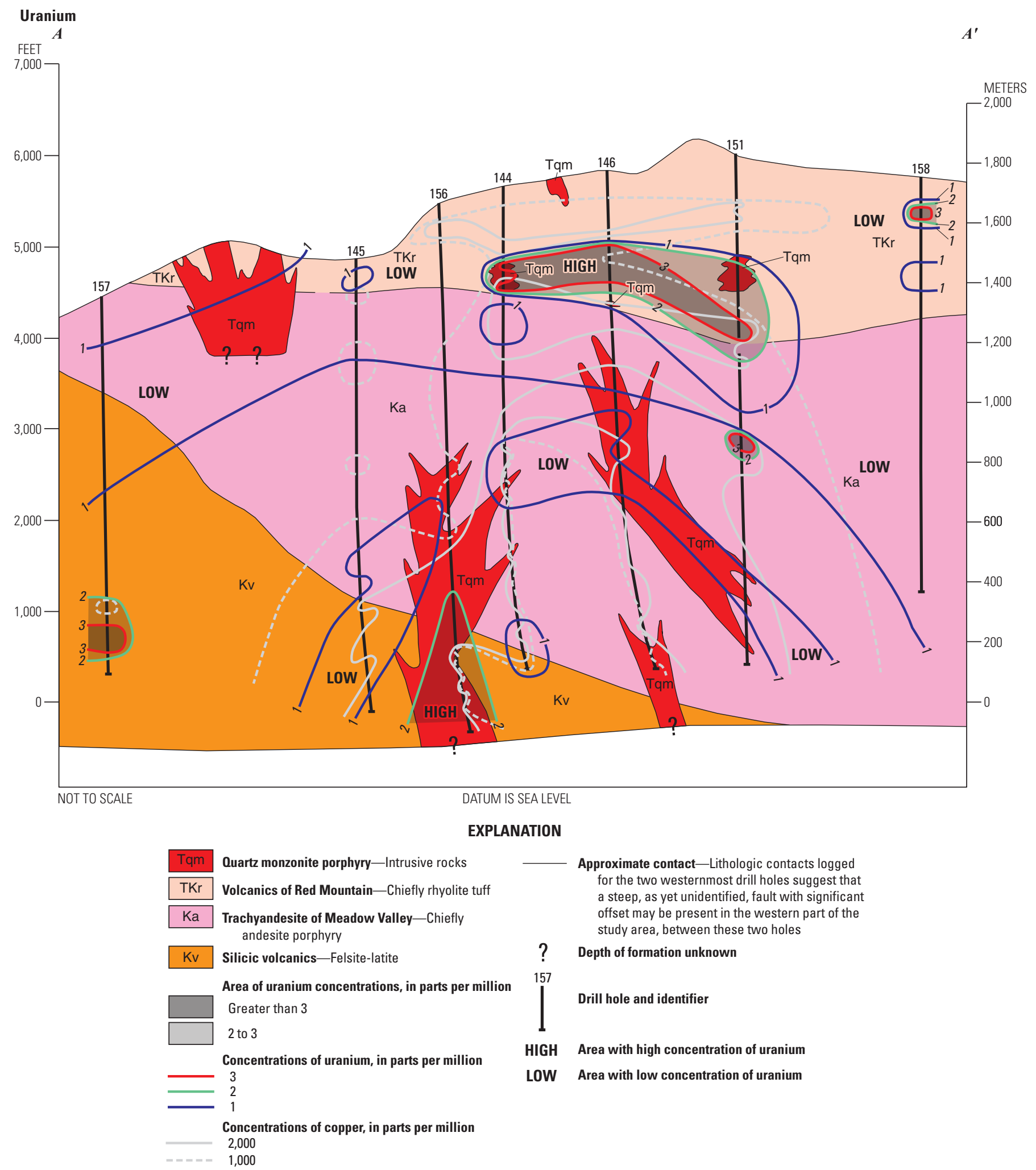

Figure 35. Distribution of uranium in core samples. 


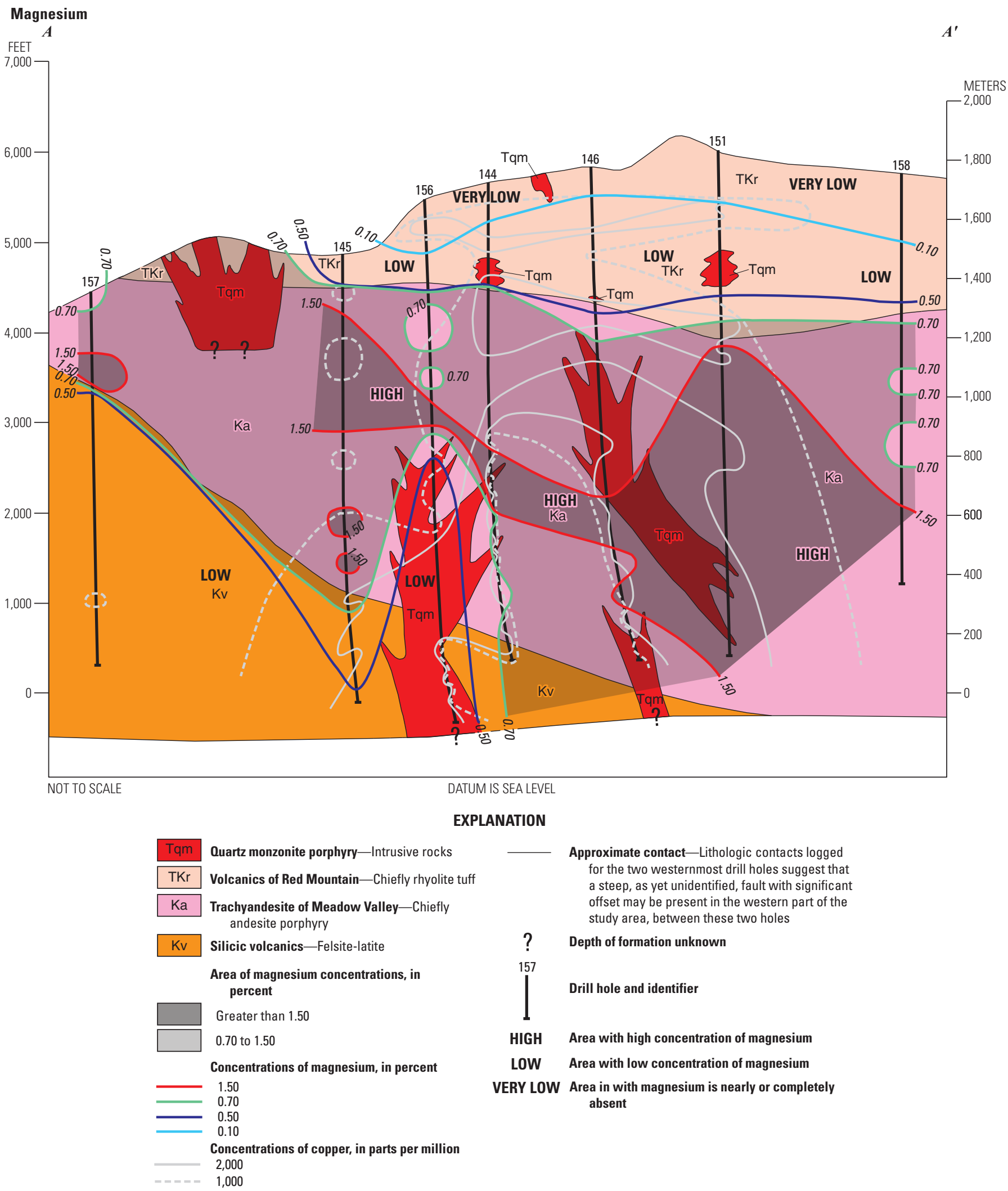

Figure 36. Distribution of magnesium in core samples. 


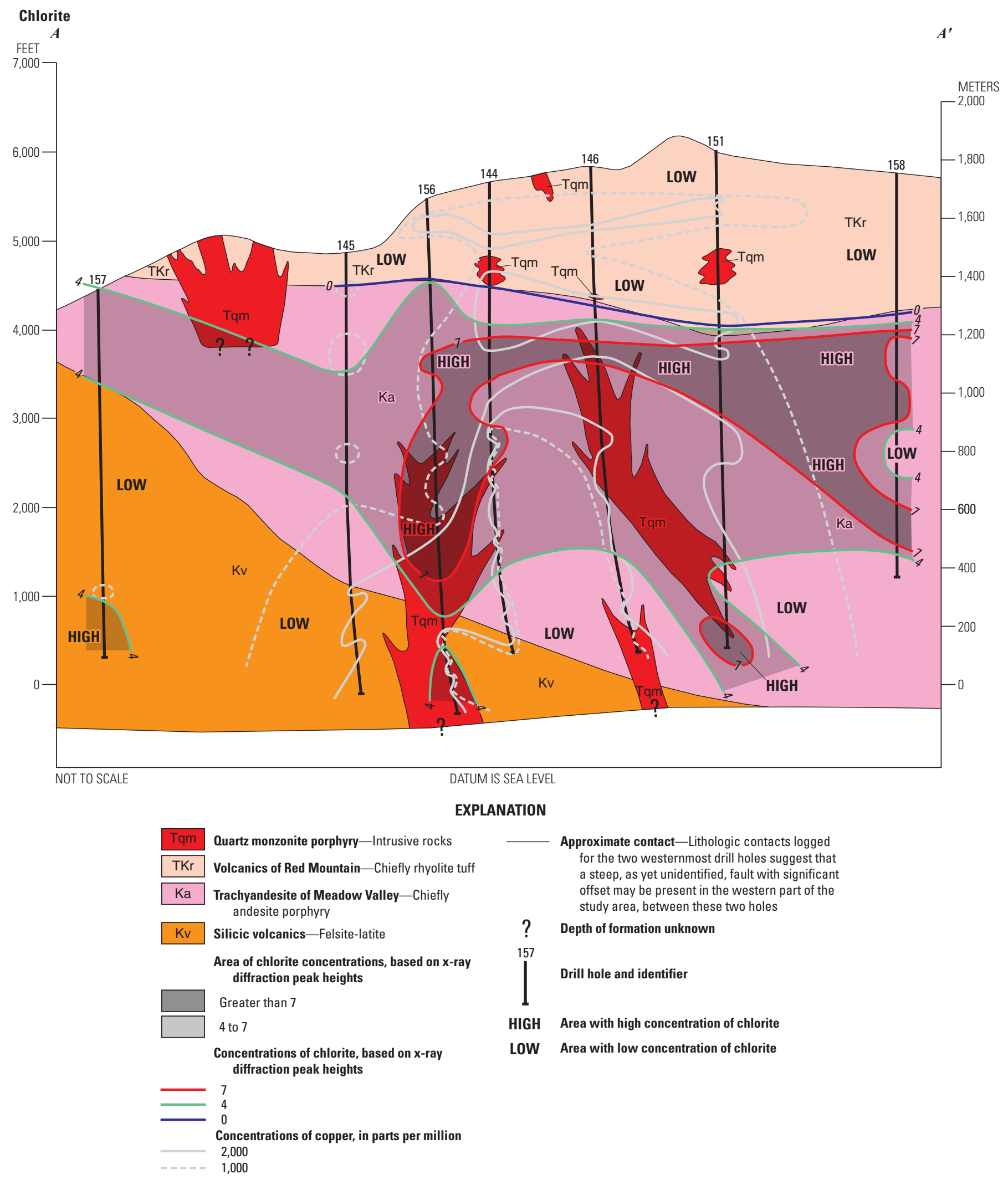

Figure 37. Distribution of chlorite in core samples. 


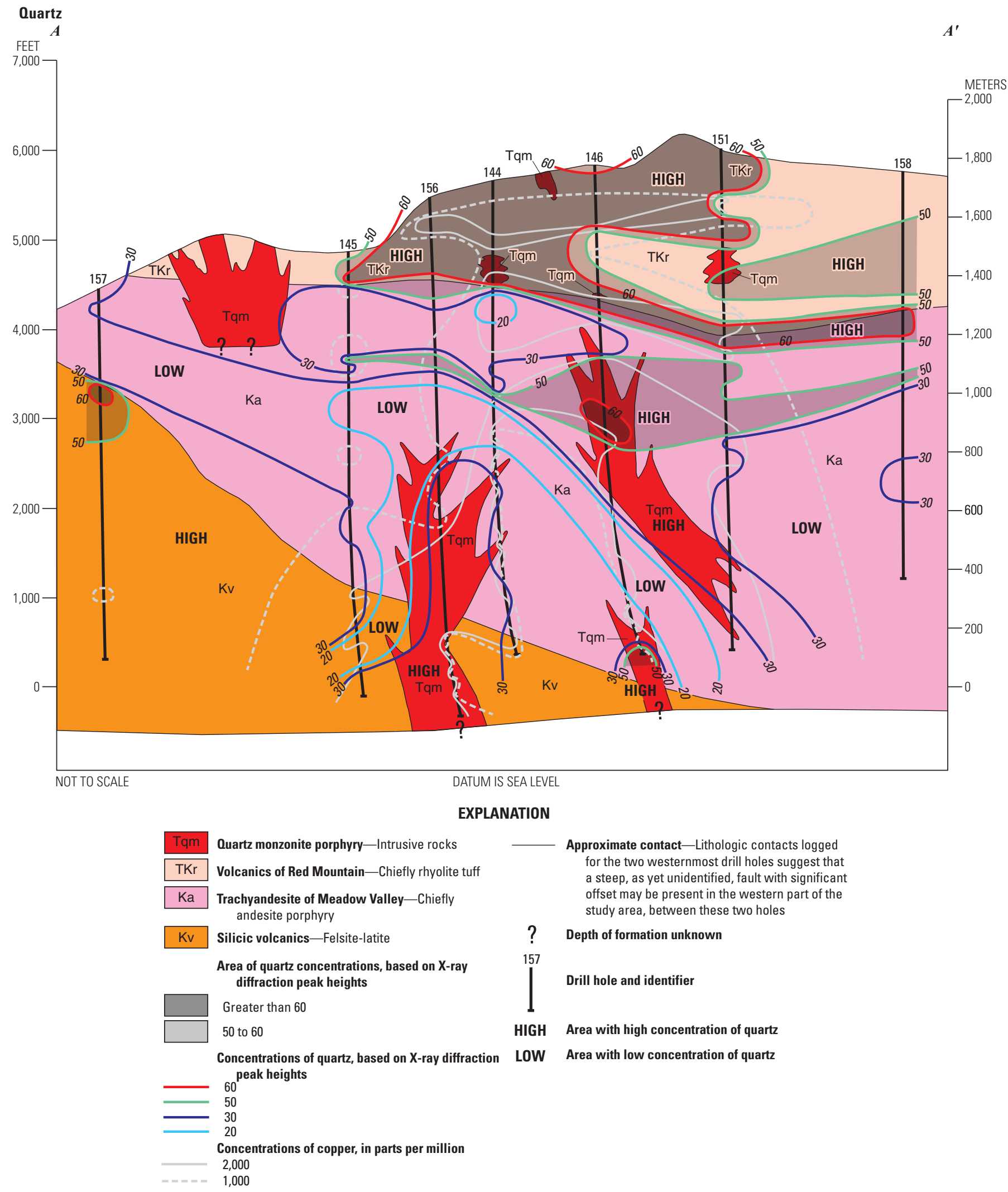

Figure 38. Distribution of quartz in core samples. 


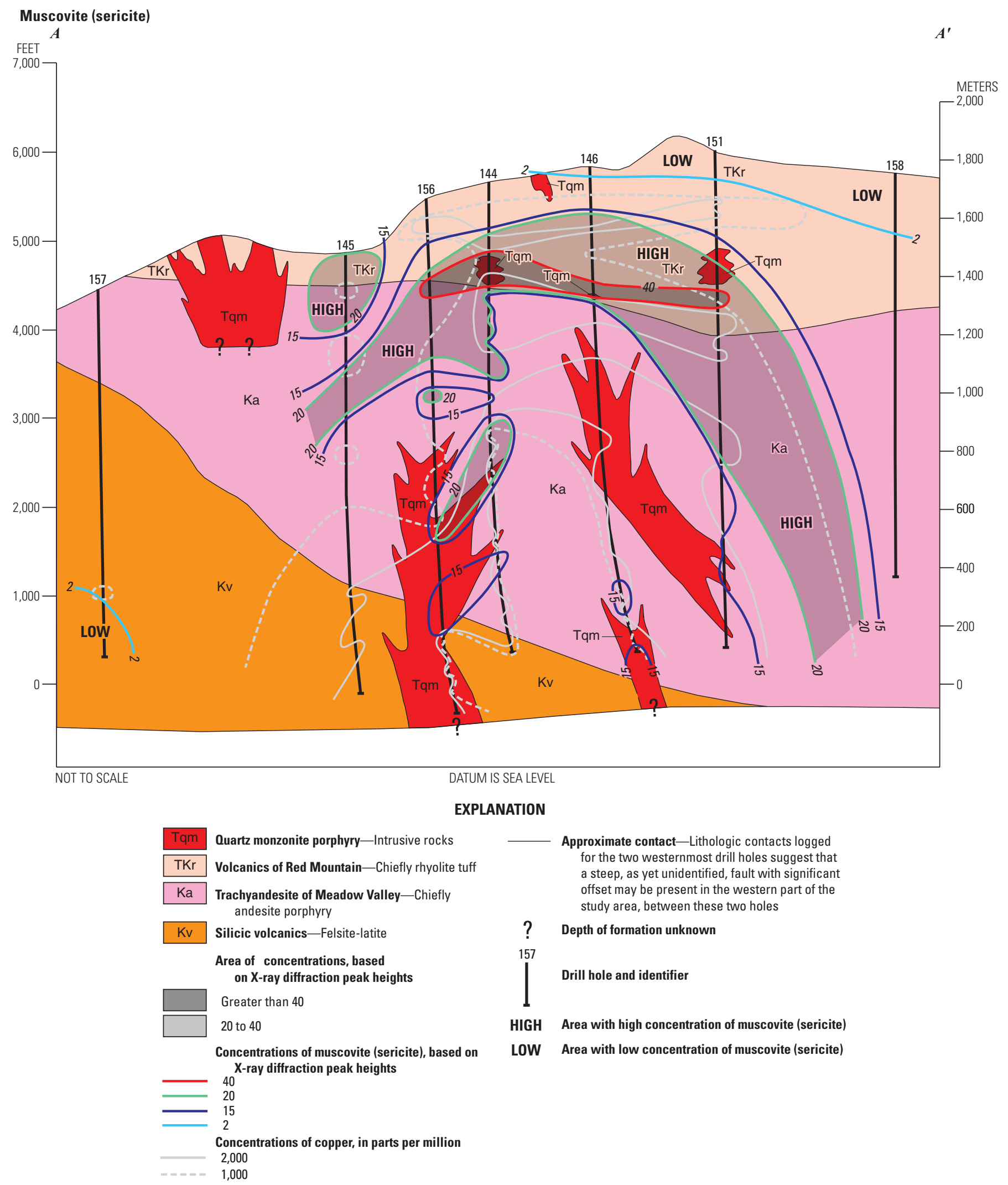

Figure 39. Distribution of muscovite (sericite) in core samples. 


\section{Part B-Surface Geochemical Studies of Rock, Soil, and Vegetation}

Surface geochemical sampling included samples of rock, soil, and three species of plants. The analyses of these samples provide detailed chemical information over a relatively undisturbed area known to be highly mineralized both at the surface and at depth. Information derived from these analyses provides base line data that may be useful for both exploration and environmental purposes.

\section{Sampling, Preparation, and Analysis}

The rock samples were collected from throughout the study area from typical outcrops of both visually fresh and altered rocks in order to characterize the chemical differences in rocks in surface exposures and identify element distributions relative to the known $\mathrm{Cu}-\mathrm{Mo}$ deposit. Soil samples were collected to identify changes in element concentrations relative to the adjacent rocks, as well as to document element distributions. The plant samples were collected to establish a multielement baseline reference database and to learn more about their chemistry relative to the underlying hypogene $\mathrm{Cu}-\mathrm{Mo}$ deposit.

A total of 122 rock samples were collected in the vicinity of the deposit. The samples were composited from outcrops within about $10 \mathrm{~m}$ of each sample site. Only material representative of the outcrops near each site was collected. Each sample was hand cobbed when necessary to remove any visibly weathered surface material not typical of the sample as a whole. Before being submitted to the laboratory, the samples were first crushed in a jaw crusher and then ground in a ceramic pulverizer to material $<0.15 \mathrm{~mm}$ (minus $100 \mathrm{mesh}$ ).

A total of 119 soil samples were also collected, mostly close to the corresponding rock sample sites. The soil samples were also composited from several subsites. The samples were collected below any obvious organic layer. Prior to submitting the samples to the laboratory, each bulk sample was sieved through stainless-steel sieves, and a $<0.18$-mm (minus 80-mesh) fraction was pulverized in a manner similar to that used for the rock samples.

Samples from three species of trees common to the region were also collected, mostly from near the corresponding rock and (or) soil sample sites. The combination of the three species collected at any given site depended on the local environment. At lower elevations, which are within the Lower Sonoran Life Zone, mesquite (Prosopis juliflora (Sw.) DC) (fig. 40A) and oak (Emory's oak, Quercus emoryi Torr.; and Mexican blue oak, Q. oblongifolia Torr) (fig. 40B) are the most common species. At higher elevations, which are within the Upper Sonoran Life Zone, oak and oneseed juniper (Juniperus monosperma (Engelm.) Sarg.) (fig. 40C) are the most common species (Integrated Taxonomic Information System, https://itis.gov, accessed August 15, 2019). A total of 57 mesquite samples, 108 oak samples, and 68 juniper samples were collected. Each sample was composited from material collected around each tree, generally at about 1.2 to $1.8 \mathrm{~m}$ above the ground surface. At each site, samples were collected from more than one tree of each species if they were available. In the case of the oak and mesquite, each sample consisted of twigs less than about $6 \mathrm{~mm}$ in diameter from which all leaves had been removed. For the juniper samples, entire branches, for which the stems did not exceed about $6 \mathrm{~mm}$ in diameter, were collected. All samples were air dried and cut into small pieces. This material was then macerated in a stainless-steel blender to produce a fine powder. An aliquot of this powder was slowly ashed in a muffle furnace for about 22 hours at temperatures that did not exceed about $450{ }^{\circ} \mathrm{C}$.

The rock, soil, and plant samples were submitted to the respective laboratories in a random order. Duplicate samples and internal standards were added to each batch to monitor the quality of the analyses. The rock and soil samples numbered PT001-PT019 were analyzed by a commercial laboratory for $\mathrm{As}, \mathrm{Au}, \mathrm{Ba}$, bromine $(\mathrm{Br})$, cerium $(\mathrm{Ce}), \mathrm{Co}, \mathrm{Cr}, \mathrm{Cs}$, europium (Eu), Fe, hafnium (Hf), $\mathrm{Hg}$, iridium (Ir), La, lutetium (Lu), $\mathrm{Na}$, neodymium $(\mathrm{Nd}), \mathrm{Rb}, \mathrm{Sb}, \mathrm{Sc}$, selenium [Se], samarium (Sm), $\mathrm{Sn}$, tantalum (Ta), terbium (Tb), Th, U, W, and ytterbium $(\mathrm{Yb})$ by instrumental neutron activation analysis (INAA), for 19 elements (Ag, aluminum [Al], beryllium [Be], $\mathrm{Bi}, \mathrm{Ca}$, cadmium [Cd], $\mathrm{Cu}, \mathrm{K}, \mathrm{Mg}, \mathrm{Mn}, \mathrm{Mo}, \mathrm{Ni}$, phosphorus [P], $\mathrm{Pb}$, $\mathrm{Sr}, \mathrm{Ti}, \mathrm{V}, \mathrm{Y}$, and Zn) using a 4-acid (hydrofluoric, perchloric, nitric, and hydrochloric acids $\left[\mathrm{HF}, \mathrm{HClO}_{4}, \mathrm{HNO}_{3}\right.$, and $\mathrm{HCl}$, respectively]) digestion followed by inductively-coupled plasma optical-emission spectrometry (ICP-OES) (ActLabs, 2000). They were also analyzed in the USGS Branch of Geochemistry laboratory in Denver for Te and Tl by atomicabsorption spectrometry (AAS) (O'Leary, 1996). Some of the soil samples were also analyzed in the same USGS laboratory for $\mathrm{S}$ by an infrared, instrumental method. The rest of the rock and soil samples (PT020-PT122) were analyzed in a commercial laboratory for 35 elements (Al, As, Ba, Be, Ca, Ce, Co, Cr, Cu, $\mathrm{Eu}, \mathrm{Fe}, \mathrm{Ga}, \mathrm{Ho}, \mathrm{K}, \mathrm{La}, \mathrm{Li}, \mathrm{Mg}, \mathrm{Mn}, \mathrm{Mo}, \mathrm{Na}, \mathrm{Nb}, \mathrm{Nd}, \mathrm{Ni}, \mathrm{P}, \mathrm{Pb}$, Sc, Sr, Ta, Th, Ti, U, V, Y, Yb, and Zn) by a modification of the inductively-coupled plasma-mass spectrometry (ICP-MS) method of Briggs and Meier (2002) (ActLabs, 2000) and in the USGS Branch of Geochemistry laboratories for Ag, $\mathrm{Au}, \mathrm{Bi}$, $\mathrm{Cd}$, and $\mathrm{Sb}$ by the inductively-coupled plasma-atomic emission spectrometry (ICP-AES) method of Motooka (1996) and for Te and Tl by AAS (O'Leary, 1996). The analyses for the rock and soil samples are tabulated and are available in a separate data release (Horton and others, 2020). 

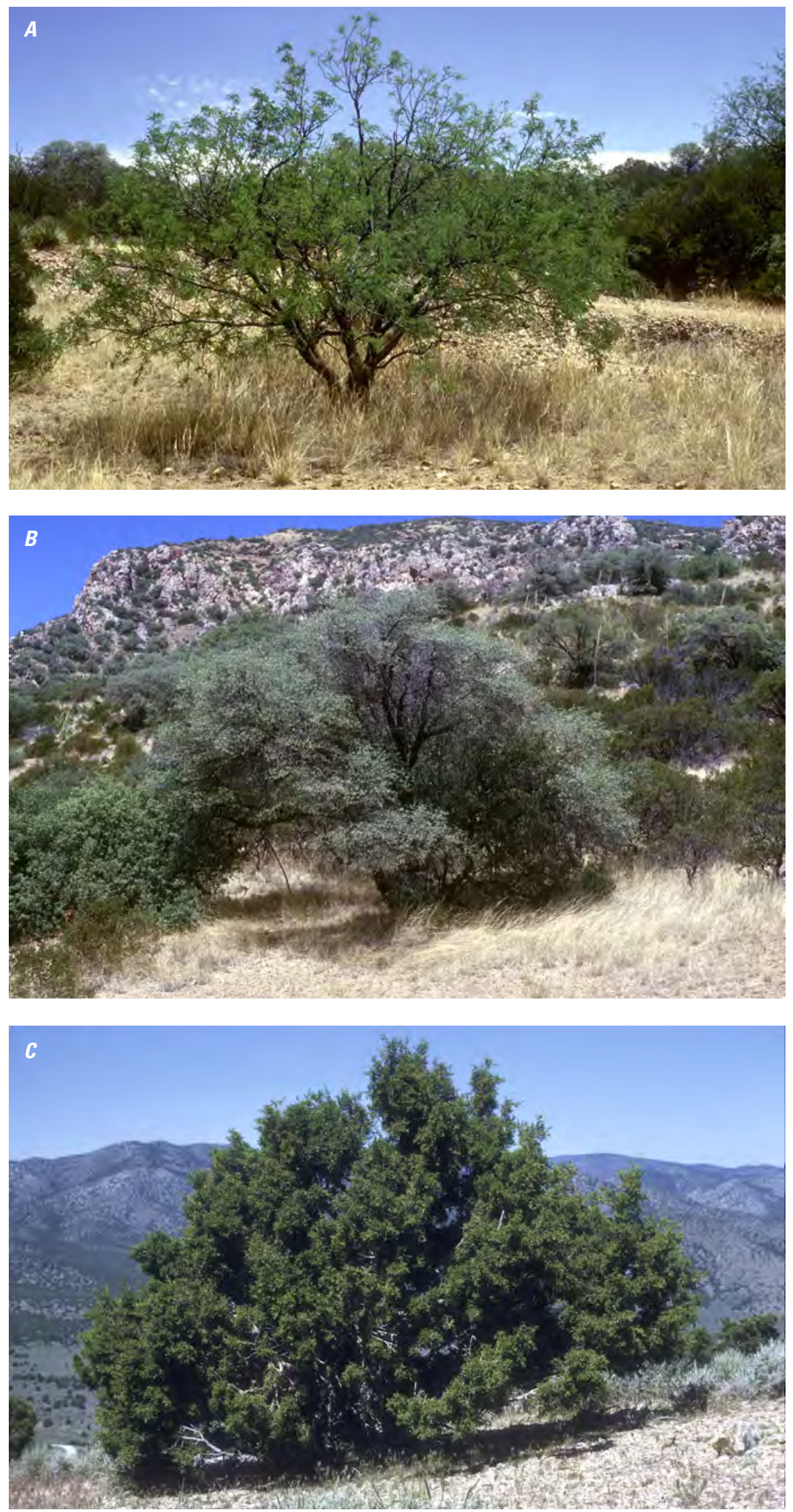

Figure 40. Photographs showing A, Mesquite (Prosopis juliflora) tree. B, Oak (Quercus spp.) trees. $C$, Oneseed juniper (Juniperus monosperma) tree. 
All samples of plant ash were analyzed in a commercial laboratory. Samples PT001-PT019 for each species were analyzed for 29 elements (As, $\mathrm{Au}, \mathrm{Ba}, \mathrm{Br}, \mathrm{Ce}, \mathrm{Co}, \mathrm{Cr}, \mathrm{Cs}, \mathrm{Eu}$, $\mathrm{Fe}, \mathrm{Hf}, \mathrm{Hg}$, Ir, La, Lu, Na, Nd, Rb, Sb, Sc, Se, Sm, Sn, Ta, Tb, Th, U, W, and Yb) by INAA and for 19 elements (Ag, Al, Be, $\mathrm{Bi}, \mathrm{Ca}, \mathrm{Cd}, \mathrm{Cu}, \mathrm{K}, \mathrm{Mg}, \mathrm{Mn}, \mathrm{Mo}, \mathrm{Ni}, \mathrm{P}, \mathrm{Pb}, \mathrm{Sr}, \mathrm{Ti}, \mathrm{V}, \mathrm{Y}$, and $\mathrm{Zn}$ ) using the same 4-acid ( $\mathrm{HF}, \mathrm{HClO}_{4}, \mathrm{HNO}_{3}$, and $\left.\mathrm{HCl}\right)$ digestion followed by ICP-OES. Samples PT020-PT122 were analyzed for as many as 66 elements (Ag, Al, As, $\mathrm{Au}, \mathrm{B}, \mathrm{Ba}, \mathrm{Be}, \mathrm{Bi}, \mathrm{Br}$, $\mathrm{Ca}, \mathrm{Cd}, \mathrm{Ce}, \mathrm{Co}, \mathrm{Cr}, \mathrm{Cs}, \mathrm{Cu}$, dysprosium [Dy], erbium [Er], Eu, $\mathrm{Fe}$, gallium [Ga], gadolinium [Gd], germanium [Ge], $\mathrm{Hf}, \mathrm{Hg}$, Ho, iodine [I], indium [In], Ir, K, La, Li, Lu, Mg, Mn, Mo, Na, $\mathrm{Nb}, \mathrm{Nd}, \mathrm{Ni}, \mathrm{P}, \mathrm{Pb}, \mathrm{Pr}, \mathrm{Rb}$, rhenium [Re], Sb, Sc, Se, silicon [Si], Sm, Sn, Sr, Ta, Tb, Te, Th, Ti, Tl, thulium [Tm], U, V, $\mathrm{W}, \mathrm{Y}, \mathrm{Yb}, \mathrm{Zn}$, and $\mathrm{Zr}$ ) using a nitric acid + hydrogen peroxide $\left(\mathrm{HNO}_{3}+\mathrm{H}_{2} \mathrm{O}_{2}\right.$ digestion followed by ICP-MS (ActLabs, 2000). Listings of the chemical analyses for the plants are available in a separate data release (Horton and others, 2020).

\section{Results and Evaluation of the Rock Chemistry}

Table 4 summarizes information for 54 elements in 122 rock samples. The median concentration values for the surface rock samples were compared to median concentration values for the same two datasets of andesite samples that are listed for the drill core samples in table 2 and described in the section, Results and Evaluation of the Core Analyses. Because median values for the dataset of 122 samples, which includes samples from both the andesite and rhyolite tuff units, are being compared to two datasets of only andesite samples, the resulting ratio values (columns $\mathrm{A} / \mathrm{B}$ and $\mathrm{A} / \mathrm{C}$, respectively) may not be meaningful for some elements related mostly to lithology but likely are valid for most of the elements introduced during formation of the hypogene $\mathrm{Cu}-\mathrm{Mo}$ deposit. For the dataset of surface rock samples (table 4), the median ratio values for deposit-related elements are generally smaller than those noted for the subsurface core samples (table 2) because the surface samples are from the uppermost remaining part of the deposit system where concentrations for many of the deposit-related elements are relatively low as compared to their concentrations at depth. The median ratio values for the rock samples (columns $\mathrm{A} / \mathrm{B}$ ratio and (or) $\mathrm{A} / \mathrm{C}$ ratio, table 4) show that the deposit-related elements $\mathrm{As}, \mathrm{Pb}, \mathrm{Te}$, and $\mathrm{Tl}$ are clearly more concentrated in these samples as compared to one or the other of the two andesite datasets. The data for other deposit-related elements (Ag, $\mathrm{Cu}, \mathrm{Mo}, \mathrm{Sb}$, and $\mathrm{Zn}$ ) are inconclusive.

\section{Results and Evaluation of the Soil Chemistry}

Table 5 summarizes, for 55 elements in 119 soil samples, the same columns of data shown in table 4. Examination of the columns listing $\mathrm{A} / \mathrm{B}$ and $\mathrm{A} / \mathrm{C}$ ratios show that the deposit-related elements $\mathrm{Ag}, \mathrm{As}, \mathrm{Cu}, \mathrm{Mo}, \mathrm{Pb}, \mathrm{Sb}, \mathrm{Te}$, and $\mathrm{Zn}$ are more concentrated in the soil as compared to one or the other of the two andesite datasets. The data for bismuth and cadmium are inconclusive.

\section{Results and Evaluation of the Vegetation Chemistry}

Many elements are considered essential to normal plant growth. Some of these essential elements are part of the suite of deposit-related elements at Red Mountain and some are not. Similarly, many other elements are nonessential for plant growth, including elements both related to, and unrelated to, the hypogene $\mathrm{Cu}-\mathrm{Mo}$ deposit. Nevertheless, nonessential elements can be taken up by plants, even when they may be considered potentially toxic to the plants. Elements essential for plant growth that were analyzed for this study include $\mathrm{Ca}, \mathrm{Cu}, \mathrm{Fe}, \mathrm{K}, \mathrm{Mg}, \mathrm{Mn}, \mathrm{Mo}, \mathrm{Na}, \mathrm{P}$, and $\mathrm{Zn}$ (Brooks, 1983). Elements analyzed that are probably nonessential, or those that are considered potentially toxic to plants, depending on their concentrations and probably other factors, include $\mathrm{Ag}, \mathrm{As}, \mathrm{Ba}, \mathrm{Bi}, \mathrm{Cd}, \mathrm{Co}, \mathrm{Cr}, \mathrm{Cu}, \mathrm{Mn}, \mathrm{Mo}, \mathrm{Ni}, \mathrm{Pb}, \mathrm{Sb}, \mathrm{Te}$, Tl, V, Zn, and probably others (Brooks, 1983; Levinson, 1974). Note that copper, manganese, molybdenum, and zinc, which are found on both lists, may be essential in low concentrations but can be toxic at higher concentrations.

Tables 6, 7, and 8 summarize data for percent ash and for 66 elements analyzed in the ash of 57 mesquite twigs, 108 oak twigs, and 68 juniper branches, respectively. For the plant samples, the median concentration values in the ash provide a means of comparing the degree of accumulation of a given element among the three species.

The concentration of a given element in plant ash is here deemed to be comparable to the concentration of that element in soil. Therefore, the ratio column (A/B) provides at least qualitative estimates of the relative concentration of each element in the ash of a given plant species (column A) as compared to its substrate soil (column B). These ratios provide an estimate of which elements are being accumulated in each of the three species. For mesquite, these elements are (in order, with ratio values in parentheses): $\mathrm{Ca}(60), \mathrm{P}(21), \mathrm{Sr}(9.1), \mathrm{K}(5.1), \mathrm{Mg}(5.0)$, Zn (5.0), Cd (2.2), Cu (1.6), and Mo (1.3) (table 6). Similarly, the elements accumulated in oak ash are: $\mathrm{Ca}(64), \mathrm{Cd}(47)$, P (22), Mn (8.8), Mg (6.8), Sr (5.4), K (>3.0), Ni (2.3), Zn (2.2), 
Table 4. Summary of chemical data for 54 elements in 122 samples of rock outcrop and comparative background data, Red Mountain, Arizona.

[All concentrations are in parts per million unless \% (percent) or ppb (parts per billion) is shown after the chemical symbol. Analytical methods are described in the text and in the associated data for this publication (Horton and others, 2020). ---, indicate no meaningful value. Values preceded by $<$ or $>$ are qualified values, which are less than or greater than, respectively, the value shown. Unqualified samples have no concentrations below the lower limit of determination or above the upper limit of determination. The ratios $\mathrm{A} / \mathrm{B}$ and $\mathrm{A} / \mathrm{C}$ give estimates of the relative enrichment $(>1.0)$ or depletion $(<1.0)$ of each element in the outcrop samples]

\begin{tabular}{|c|c|c|c|c|c|c|c|c|c|}
\hline \multicolumn{6}{|c|}{ Rock outcrop data } & \multicolumn{4}{|c|}{ Comparative background data } \\
\hline Element & $\begin{array}{c}\text { Range of } \\
\text { values }\end{array}$ & $\begin{array}{l}\text { Number } \\
\text { analyzed }\end{array}$ & $\begin{array}{c}\text { Percent } \\
\text { analyzed of } \\
122 \text { samples }\end{array}$ & $\begin{array}{c}\text { Percent } \\
\text { unqualified of } \\
122 \text { samples }\end{array}$ & $\begin{array}{l}\text { Median value } \\
\text { rock samples } \\
\text { (A) }\end{array}$ & $\begin{array}{l}\text { Median value of } \\
27 \text { local andesite } \\
\text { samples }^{2}(B)\end{array}$ & $\begin{array}{l}\mathrm{A} / \mathrm{B} \\
\text { ratio }\end{array}$ & $\begin{array}{l}\text { Median value of } 46 \\
\text { regional andesite } \\
\text { samples }^{3} \text { (C) }\end{array}$ & $\begin{array}{c}\mathrm{A} / \mathrm{C} \\
\text { ratio }\end{array}$ \\
\hline $\mathrm{Ag}^{1}$ & $<0.08-54.5$ & 122 & 100 & 48 & $<0.5$ & $<0.008$ & --- & $<0.5$ & --- \\
\hline $\mathrm{A}^{1}(\%)$ & $2.81-12.5$ & 122 & 100 & 100 & 8.36 & --- & --- & --- & --- \\
\hline $\mathrm{Ba}$ & $83-2,490$ & 122 & 100 & 100 & 764 & 851 & 0.90 & 1,000 & 0.76 \\
\hline $\mathrm{Be}^{1}$ & $<1.0-6.0$ & 122 & 100 & 52 & 1.0 & 2 & 0.50 & 1.0 & 1.00 \\
\hline $\mathrm{Bi}^{1}$ & $<1-32$ & 122 & 100 & 30 & $<1.0$ & $<1$ & --- & $<10$ & --- \\
\hline $\mathrm{Br}$ & $<0.5-<0.5$ & 19 & 16 & 0 & --- & --- & --- & --- & --- \\
\hline $\mathrm{Co}^{1}$ & $<1.0-37$ & 122 & 100 & 70 & 5 & 23 & 0.28 & 20 & 0.25 \\
\hline $\mathrm{Cr}^{1}$ & $<2.0-150$ & 122 & 100 & 64 & 5.5 & 24 & 0.23 & 50 & 0.11 \\
\hline Cs & $2-36$ & 19 & 16 & 16 & --- & --- & --- & 50 & --- \\
\hline $\mathrm{Cu}$ & $<2-417$ & 122 & 100 & 98 & 44 & 47 & 0.94 & 40 & 1.10 \\
\hline $\mathrm{Eu}^{1}$ & $<0.9-4$ & 122 & 100 & 43 & $<2$ & --- & --- & --- & --- \\
\hline $\mathrm{Fe}(\%)$ & $0.12-9.16$ & 122 & 100 & 100 & 3.54 & 5.22 & 0.68 & 3.00 & 1.18 \\
\hline $\mathrm{Ga}$ & $7-55$ & 103 & 84 & 84 & 20 & --- & --- & --- & --- \\
\hline $\mathrm{Hf}$ & $4-13$ & 19 & 16 & 16 & --- & --- & --- & --- & --- \\
\hline $\mathrm{Hg}$ & $<1-<1$ & 19 & 16 & 0 & --- & --- & --- & $<0.02$ & --- \\
\hline $\operatorname{Mg}(\%)$ & $0.01-3.91$ & 122 & 100 & 100 & 0.32 & 2.23 & 0.14 & 1.25 & 0.26 \\
\hline $\mathrm{Mn}$ & $<4-1930$ & 122 & 100 & 84 & 144 & 826 & 0.17 & 500 & 0.31 \\
\hline Mo & $<2-176$ & 122 & 100 & 82 & 3 & 3 & 1.00 & $<5$ & $>0.60$ \\
\hline $\mathrm{Na}(\%)$ & $0.01-4.22$ & 122 & 100 & 100 & 0.38 & 2.49 & 0.15 & 2.45 & 0.16 \\
\hline $\mathrm{Nb}$ & $<4-31$ & 103 & 84 & 57 & 8.0 & 18 & 0.44 & $<20$ & $>0.40$ \\
\hline $\mathrm{Nd}$ & $<9-71$ & 122 & 100 & 91 & 31 & --- & --- & --- & --- \\
\hline $\mathrm{Ni}^{1}$ & $<2-123$ & 122 & 100 & 61 & 5.0 & 46 & 0.11 & 20 & 0.25 \\
\hline P (\%) & $0.005-0.26$ & 122 & 100 & 100 & 0.080 & --- & --- & --- & --- \\
\hline $\mathrm{Pb}^{1}$ & $<4-2,370$ & 122 & 100 & 97 & 39 & 11 & 3.55 & 50 & 0.78 \\
\hline $\mathrm{Rb}$ & $<5-310$ & 19 & 16 & 15 & --- & --- & --- & --- & --- \\
\hline
\end{tabular}


Table 4. Summary of chemical data for 54 elements in 122 samples of rock outcrop and comparative background data, Red Mountain, Arizona.

[All concentrations are in parts per million unless \% (percent) or ppb (parts per billion) is shown after the chemical symbol. Analytical methods are described in the text and in the associated data for this publication (Horton and others, 2020). ---, indicate no meaningful value. Values preceded by $<$ or $>$ are qualified values, which are less than or greater than, respectively, the value shown. Unqualified samples have no concentrations below the lower limit of determination or above the upper limit of determination. The ratios $\mathrm{A} / \mathrm{B}$ and $\mathrm{A} / \mathrm{C}$ give estimates of the relative enrichment $(>1.0)$ or depletion $(<1.0)$ of each element in the outcrop samples]

\begin{tabular}{|c|c|c|c|c|c|c|c|c|c|}
\hline \multicolumn{6}{|c|}{ Rock outcrop data } & \multicolumn{4}{|c|}{ Comparative background data } \\
\hline Element & $\begin{array}{c}\text { Range of } \\
\text { values }\end{array}$ & $\begin{array}{l}\text { Number } \\
\text { analyzed }\end{array}$ & $\begin{array}{c}\text { Percent } \\
\text { analyzed of } \\
122 \text { samples }\end{array}$ & $\begin{array}{c}\text { Percent } \\
\text { unqualified of } \\
122 \text { samples }\end{array}$ & $\begin{array}{l}\text { Median value } \\
\text { rock samples } \\
\text { (A) }\end{array}$ & $\begin{array}{l}\text { Median value of } \\
27 \text { local andesite } \\
\text { samples }^{2}(B)\end{array}$ & $\begin{array}{c}\text { A/B } \\
\text { ratio }\end{array}$ & $\begin{array}{l}\text { Median value of } 46 \\
\text { regional andesite } \\
\text { samples }^{3} \text { (C) }\end{array}$ & $\begin{array}{l}\mathrm{A} / \mathrm{C} \\
\text { ratio }\end{array}$ \\
\hline $\mathrm{Sb}^{1}$ & $<0.5-261$ & 122 & 100 & 57 & 1.0 & $<1.0$ & $>1.0$ & $<2$ & $>0.5$ \\
\hline $\mathrm{Sc}$ & $<2-28$ & 122 & 100 & 99 & 11 & 17 & 0.65 & 15 & 0.73 \\
\hline $\mathrm{Se}$ & $<3.0-3.0$ & 19 & 100 & 1 & --- & --- & --- & --- & --- \\
\hline $\mathrm{Sm}$ & $3.2-12$ & 19 & 16 & 16 & --- & -- & --- & -- & --- \\
\hline $\mathrm{Sn}$ & $<100-<50$ & 122 & 100 & 0 & --- & $<10$ & --- & $<10$ & --- \\
\hline $\mathrm{Sr}$ & $<1-1,760$ & 122 & 100 & 99 & 285 & 612 & 0.47 & 300 & 0.95 \\
\hline $\mathrm{Ta}^{1}$ & $<0.5-2.0$ & 122 & 100 & 5 & --- & --- & --- & --- & --- \\
\hline $\mathrm{Tb}$ & $<0.5-1.9$ & 19 & 16 & 3 & --- & --- & --- & --- & --- \\
\hline $\mathrm{Te}$ & $<0.1-4.60$ & 122 & 100 & 66 & 0.2 & $<0.1$ & $>2.0$ & $<0.01$ & $>20$ \\
\hline $\mathrm{Th}$ & 6-58 & 122 & 100 & 100 & 18 & 17 & 1.06 & --- & --- \\
\hline $\operatorname{Ti}(\%)$ & $0.023-0.75$ & 122 & 100 & 100 & 0.35 & 0.62 & 0.56 & 0.50 & 0.69 \\
\hline $\mathrm{T}^{1}$ & $<0.1-9.4$ & 122 & 100 & 93 & 1.0 & 0.2 & 5.00 & 0.18 & 5.56 \\
\hline $\mathrm{U}^{1}$ & $<2-18$ & 122 & 16 & 16 & --- & --- & --- & 1.90 & --- \\
\hline $\mathrm{V}$ & $3-461$ & 122 & 100 & 100 & 113 & 93 & 1.22 & 100 & 1.13 \\
\hline W & $<1-6$ & 19 & 16 & 2 & --- & --- & --- & $<50$ & --- \\
\hline Y & $<2-44$ & 122 & 100 & 95 & 14 & 23 & 0.61 & 20 & 0.70 \\
\hline $\mathrm{Yb}$ & $<1.0-9$ & 122 & 100 & 73 & 2.0 & --- & --- & --- & --- \\
\hline $\mathrm{Zn}$ & $<2-765$ & 122 & 100 & 99 & 74 & 89 & 0.83 & 60 & 1.23 \\
\hline
\end{tabular}

${ }^{1}$ More than one lower limit of determination reported. The lowest value is shown.

${ }^{2}$ Subset of the 122 samples in the rock dataset (table 4) consisting of analyses of unaltered or slightly propylitically-altered andesite rock samples collected within the study area but outside of the area of influence of the Red Mountain deposit.

${ }^{3}$ Subset of unaltered or slightly propylitically-altered andesite rock samples collected generally from the area immediately north of the study area. Sample analyses are from the U.S. Geological Survey National Geochemical Database. 
Table 5. Summary of chemical data for 55 elements in 119 soil samples and comparative background data, Red Mountain, Arizona.

[All concentrations are in parts per million unless \% (percent) or ppb (parts per billion) is shown after the chemical symbol. Analytical methods are described in the text and in the associated data for this publication (Horton and others, 2020). ---, indicate no meaningful value. Values preceded by $<$ or $>$ are qualified values, which are less than or greater than, respectively, the value shown. Unqualified samples have no concentrations below the lower limit of determination or above the upper limit of determination. The ratios $\mathrm{A} / \mathrm{B}$ and $\mathrm{A} / \mathrm{C}$ give estimates of the relative enrichment $(>1.0)$ or depletion $(<1.0)$ of each element in the soil samples]

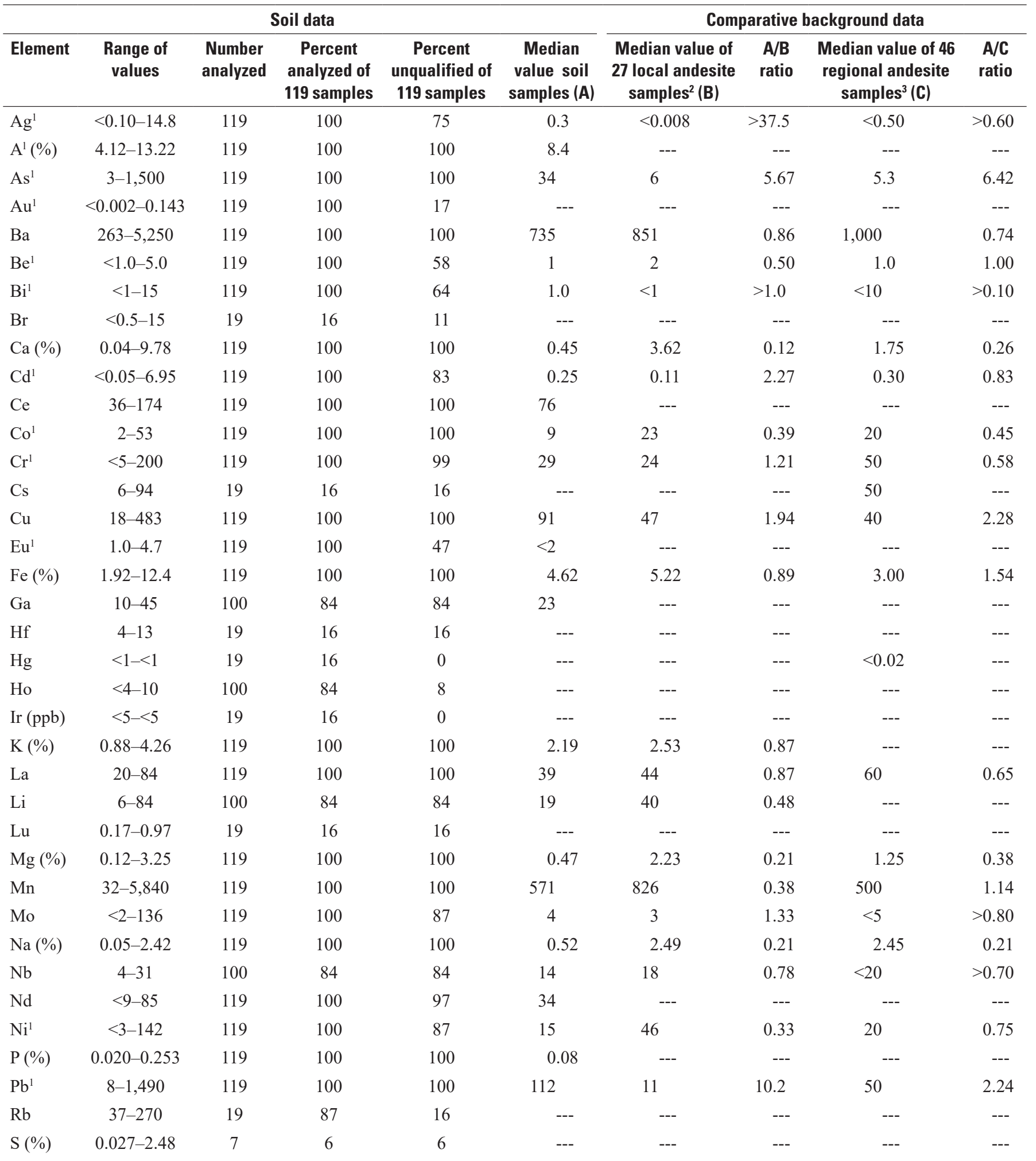


Table 5. Summary of chemical data for 55 elements in 119 soil samples and comparative background data, Red Mountain, Arizona.

[All concentrations are in parts per million unless \% (percent) or ppb (parts per billion) is shown after the chemical symbol. Analytical methods are described in the text and in the associated data for this publication (Horton and others, 2020). ---, indicate no meaningful value. Values preceded by $<$ or $>$ are qualified values, which are less than or greater than, respectively, the value shown. Unqualified samples have no concentrations below the lower limit of determination or above the upper limit of determination. The ratios $\mathrm{A} / \mathrm{B}$ and $\mathrm{A} / \mathrm{C}$ give estimates of the relative enrichment $(>1.0)$ or depletion $(<1.0)$ of each element in the soil samples]

\begin{tabular}{|c|c|c|c|c|c|c|c|c|c|}
\hline \multicolumn{6}{|c|}{ Soil data } & \multicolumn{4}{|c|}{ Comparative background data } \\
\hline Element & $\begin{array}{c}\text { Range of } \\
\text { values }\end{array}$ & $\begin{array}{l}\text { Number } \\
\text { analyzed }\end{array}$ & $\begin{array}{c}\text { Percent } \\
\text { analyzed of } \\
119 \text { samples }\end{array}$ & $\begin{array}{c}\text { Percent } \\
\text { unqualified of } \\
119 \text { samples }\end{array}$ & $\begin{array}{c}\text { Median } \\
\text { value soil } \\
\text { samples (A) }\end{array}$ & $\begin{array}{l}\text { Median value of } \\
27 \text { local andesite } \\
\text { samples }^{2} \text { (B) }\end{array}$ & $\begin{array}{l}\mathrm{A} / \mathrm{B} \\
\text { ratio }\end{array}$ & $\begin{array}{l}\text { Median value of } 46 \\
\text { regional andesite } \\
\text { samples }^{3} \text { (C) }\end{array}$ & $\begin{array}{l}\mathrm{A} / \mathrm{C} \\
\text { ratio }\end{array}$ \\
\hline $\mathrm{Sb}^{1}$ & $<1.0-40$ & 119 & 100 & 89 & 3.0 & $<1.0$ & $>3.0$ & $<2$ & $>1.5$ \\
\hline $\mathrm{Sc}$ & $4-44$ & 119 & 100 & 100 & 12 & 17 & 0.71 & 15 & 0.80 \\
\hline $\mathrm{Se}$ & $<3.0-<3.0$ & 19 & 16 & 0 & --- & --- & --- & --- & --- \\
\hline $\mathrm{Sm}$ & $4.2-14$ & 119 & 100 & 16 & --- & --- & --- & --- & --- \\
\hline $\mathrm{Sn}$ & $<200-<100$ & 119 & 100 & 0 & --- & $<10$ & --- & $<10$ & --- \\
\hline $\mathrm{Sr}$ & $72-1,420$ & 119 & 100 & 100 & 268 & 612 & 0.44 & 300 & 0.89 \\
\hline $\mathrm{Ta}^{1}$ & $<0.5-2.4$ & 119 & 100 & 6 & --- & --- & --- & --- & --- \\
\hline $\mathrm{Tb}$ & $<0.5-1.7$ & 19 & 16 & 5 & --- & --- & --- & --- & --- \\
\hline $\mathrm{Te}$ & $<0.1-8.3$ & 119 & 100 & 87 & 0.6 & $<0.1$ & $>6.0$ & $<0.01$ & $>60$ \\
\hline $\mathrm{Th}$ & 6-72 & 119 & 100 & 100 & 18 & 17 & 1.06 & --- & -- \\
\hline $\mathrm{Ti}(\%)$ & $0.128-0.980$ & 119 & 100 & 100 & 0.37 & 0.62 & 0.60 & 0.50 & 0.74 \\
\hline $\mathrm{T}^{1}$ & $0.1-11.7$ & 119 & 100 & 99 & 1.5 & 0.2 & 7.50 & 0.18 & 8.33 \\
\hline $\mathrm{U}^{1}$ & $<2.0-19$ & 19 & 16 & 16 & --- & --- & --- & 1.90 & --- \\
\hline V & $26-405$ & 119 & 100 & 100 & 131 & 93 & 1.41 & 100 & 1.31 \\
\hline W & $<1-12$ & 19 & 16 & 3 & --- & --- & --- & $<50$ & --- \\
\hline $\mathrm{Y}$ & $4-56$ & 119 & 100 & 100 & 16 & 23 & 0.70 & 20 & 0.80 \\
\hline $\mathrm{Yb}$ & $<1.0-5.9$ & 119 & 100 & 86 & 2 & --- & --- & --- & --- \\
\hline $\mathrm{Zn}$ & $23-1,260$ & 119 & 100 & 100 & 103 & 89 & 1.16 & 60 & 1.72 \\
\hline
\end{tabular}

${ }^{1}$ More than one lower limit of determination reported. The lowest value is shown.

${ }^{2}$ Subset of the 122 samples in the rock dataset (table 4) consisting of analyses of unaltered or slightly propylitically-altered andesite rock samples collected within the study area but outside of the area of influence of the Red Mountain deposit.

${ }^{3}$ Subset of unaltered or slightly propylitically-altered andesite rock samples collected generally from the area immediately north of the study area. Sample analyses are from the U.S. Geological Survey National Geochemical Database. 
Table 6. Summary of chemical data for ash and 66 elements in 57 mesquite ash samples, Red Mountain, Arizona.

[All concentrations are in parts per million unless \% (percent) or ppb (parts per billion) is shown after the chemical symbol. Analytical methods are described in the text and in the associated data for this publication (Horton and others, 2020). ---, indicate no meaningful value. Values preceded by $<$ or $>$ are qualified values, which are less than or greater than, respectively, the value shown. Unqualified samples have no concentrations below the lower limit of determination or above the upper limit of determination. The ratio A/B gives an estimate of the relative enrichment $(>1.0)$ or depletion $(<1.0)$ of each element in the mesquite samples]

\begin{tabular}{|c|c|c|c|c|c|c|c|}
\hline $\begin{array}{l}\text { Element or } \\
\text { variable }\end{array}$ & Range of values & $\begin{array}{l}\text { Number } \\
\text { analyzed }\end{array}$ & $\begin{array}{l}\text { Percent analyzed } \\
\text { of } 57 \text { samples }\end{array}$ & $\begin{array}{l}\text { Percent unqualified } \\
\text { of } 57 \text { samples }\end{array}$ & $\begin{array}{l}\text { Median value } \\
\text { in ash (A) }\end{array}$ & $\begin{array}{l}\text { Median value } \\
\text { in soils (B) }\end{array}$ & $A / B$ ratio \\
\hline Ash (\%) & $2.90-7.90$ & 57 & 100 & 100 & 5.70 & --- & $\begin{array}{l}-- \\
\end{array}$ \\
\hline $\mathrm{Ag}^{1}$ & $<0.40-2.30$ & 57 & 100 & 82 & 0.27 & 0.30 & 0.90 \\
\hline $\mathrm{Al}$ & $70-2,580$ & 42 & 74 & 74 & 843 & 84,000 & 0.010 \\
\hline As & $<0.5-30.7$ & 57 & 100 & 95 & 1.7 & 34 & 0.05 \\
\hline $\mathrm{Au}(\mathrm{ppb})$ & $<2.0-7.0$ & 13 & 23 & 9 & $<2.0$ & --- & --- \\
\hline B & $179-376$ & 44 & 77 & 77 & 282 & --- & --- \\
\hline $\mathrm{Ba}$ & $87-2,570$ & 57 & 100 & 100 & 710 & 735 & 0.97 \\
\hline $\mathrm{Be}^{1}$ & $0.016-0.548$ & 57 & 100 & 77 & 0.041 & 1.0 & 0.041 \\
\hline $\mathrm{Bi}^{1}$ & $0.050-6.0$ & 57 & 100 & 81 & 0.07 & 1.0 & 0.07 \\
\hline $\mathrm{Br}$ & $43-130$ & 13 & 23 & 23 & 64 & --- & --- \\
\hline $\mathrm{Ca}(\%)$ & $13.57-35.77$ & 42 & 74 & 74 & 26.61 & 0.45 & 60 \\
\hline $\mathrm{Cd}^{1}$ & $0.19-6.60$ & 57 & 100 & 75 & 0.54 & 0.25 & 2.2 \\
\hline $\mathrm{Ce}^{1}$ & $2.08-8.95$ & 57 & 100 & 88 & 3.18 & 76 & 0.042 \\
\hline Co & $0.85-10.0$ & 57 & 100 & 100 & 1.51 & 9.0 & 0.17 \\
\hline $\mathrm{Cr}^{1}$ & $0.6-8.0$ & 57 & 100 & 82 & 1.50 & 29 & 0.052 \\
\hline $\mathrm{Cs}^{1}$ & $0.3-1,220$ & 57 & 100 & 98 & 42 & --- & --- \\
\hline $\mathrm{Cu}$ & $64-211$ & 57 & 100 & 100 & 147 & 91 & 1.6 \\
\hline Dy & $0.053-0.876$ & 44 & 77 & 77 & 0.159 & --- & --- \\
\hline Er & $0.030-0.341$ & 44 & 77 & 77 & 0.075 & --- & --- \\
\hline $\mathrm{Eu}^{1}$ & $0.054-0.823$ & 57 & 100 & 77 & 0.202 & $<2.0$ & \\
\hline $\mathrm{Fe}(\%)$ & $0.13-0.485$ & 57 & 100 & 100 & 0.24 & 4.62 & 0.052 \\
\hline $\mathrm{Ga}$ & $0.171-1.002$ & 44 & 77 & 77 & 0.314 & 23 & 0.014 \\
\hline Gd & $0.102-1.541$ & 44 & 77 & 77 & 0.333 & --- & --- \\
\hline $\mathrm{Ge}$ & $<0.010-0.045$ & 44 & 77 & 75 & 0.022 & --- & --- \\
\hline $\mathrm{Hf}^{1}$ & $<0.010-0.055$ & 57 & 100 & 61 & 0.018 & --- & --- \\
\hline $\mathrm{Hg}$ & $<1.0-1.0$ & 13 & 23 & 2 & --- & --- & --- \\
\hline Но & $0.010-0.149$ & 44 & 77 & 77 & 0.028 & --- & --- \\
\hline I & $<0.10-0.20$ & 15 & 26 & 2 & --- & --- & --- \\
\hline $\operatorname{In}(\mathrm{ppb})^{1}$ & $0.963-8.30$ & 44 & 77 & 75 & 4.89 & --- & --- \\
\hline Ir (ppb) & $<5.0-<5.0$ & 13 & 23 & 0 & --- & --- & --- \\
\hline K (\%) & $3.87->11.10$ & 42 & 74 & 39 & 11.10 & 2.19 & 5.1 \\
\hline $\mathrm{La}$ & $0.69-6.17$ & 57 & 100 & 100 & 1.40 & 39 & 0.036 \\
\hline $\mathrm{Li}$ & $<1.00-9.0$ & 44 & 77 & 70 & 2.0 & 19 & 0.11 \\
\hline $\mathrm{Lu}^{1}$ & $0.004-0.024$ & 57 & 100 & 77 & 0.007 & --- & --- \\
\hline $\operatorname{Mg}(\%)$ & $1.08-7.58$ & 57 & 100 & 100 & 2.35 & 0.47 & 5.0 \\
\hline $\mathrm{Mn}$ & $176-1,200$ & 57 & 100 & 100 & 381 & 571 & 0.67 \\
\hline Mo & $1.20-83.8$ & 57 & 100 & 100 & 5.3 & 4.0 & 1.3 \\
\hline $\mathrm{Na}(\%)$ & $0.03-0.18$ & 57 & 100 & 100 & 0.07 & 0.52 & 0.14 \\
\hline $\mathrm{Nb}^{1}$ & $0.025-0.087$ & 44 & 77 & 54 & 0.033 & 14 & 0.0024 \\
\hline
\end{tabular}


Table 6. Summary of chemical data for ash and 66 elements in 57 mesquite ash samples, Red Mountain, Arizona.

[All concentrations are in parts per million unless \% (percent) or ppb (parts per billion) is shown after the chemical symbol. Analytical methods are described in the text and in the associated data for this publication (Horton and others, 2020). ---, indicate no meaningful value. Values preceded by $<$ or $>$ are qualified values, which are less than or greater than, respectively, the value shown. Unqualified samples have no concentrations below the lower limit of determination or above the upper limit of determination. The ratio A/B gives an estimate of the relative enrichment $(>1.0)$ or depletion $(<1.0)$ of each element in the mesquite samples]

\begin{tabular}{|c|c|c|c|c|c|c|c|}
\hline $\begin{array}{c}\text { Element or } \\
\text { variable }\end{array}$ & Range of values & $\begin{array}{c}\text { Number } \\
\text { analyzed }\end{array}$ & $\begin{array}{l}\text { Percent analyzed } \\
\text { of } 57 \text { samples }\end{array}$ & $\begin{array}{l}\text { Percent unqualified } \\
\text { of } 57 \text { samples }\end{array}$ & $\begin{array}{l}\text { Median value } \\
\text { in ash (A) }\end{array}$ & $\begin{array}{l}\text { Median value } \\
\text { in soils (B) }\end{array}$ & $A / B$ ratio \\
\hline $\mathrm{Nd}^{1}$ & $0.51-5.05$ & 57 & 100 & 77 & 1.08 & 34 & 0.032 \\
\hline $\mathrm{Ni}$ & $2.0-43$ & 57 & 100 & 100 & 8.9 & 15 & 0.59 \\
\hline $\mathrm{P}(\%)$ & $1.180-2.492$ & 13 & 23 & 23 & 1.69 & 0.080 & 21 \\
\hline $\mathrm{Pb}^{1}$ & $1.1-203$ & 57 & 100 & 91 & 4.6 & 112 & 0.04 \\
\hline $\operatorname{Pr}$ & $0.140-1.294$ & 44 & 77 & 77 & 0.299 & --- & --- \\
\hline $\mathrm{Rb}$ & $29-1,070$ & 57 & 100 & 100 & 137 & --- & --- \\
\hline $\mathrm{Re}$ & $2.0-150$ & 44 & 77 & 77 & 16.7 & --- & -- \\
\hline $\mathrm{Sb}^{1}$ & $0.05-5.90$ & 57 & 100 & 98 & 0.12 & 3.0 & 0.04 \\
\hline $\mathrm{Sc}$ & $0.18-1.23$ & 42 & 74 & 74 & 0.335 & 12 & 0.028 \\
\hline $\mathrm{Se}^{1}$ & $0.57-10.0$ & 19 & 33 & 82 & 1.10 & --- & --- \\
\hline $\mathrm{Si}$ & $294-625$ & 29 & 51 & 51 & 416 & --- & --- \\
\hline $\mathrm{Sm}$ & $0.100-1.02$ & 19 & 33 & 100 & 0.26 & --- & --- \\
\hline $\mathrm{Sn}^{1}$ & $1.0-1.0$ & 57 & 100 & 61 & 1.0 & --- & --- \\
\hline $\mathrm{Sr}$ & $807-6,800$ & 57 & 100 & 100 & 2430 & 268 & 9.1 \\
\hline $\mathrm{Ta}^{1}$ & $0.001-0.002$ & 57 & 100 & 11 & $<0.01$ & -- & --- \\
\hline $\mathrm{Tb}^{1}$ & $0.001-0.196$ & 19 & 33 & 77 & 0.027 & --- & -- \\
\hline $\mathrm{Te}^{1}$ & $0.012-0.066$ & 29 & 51 & 51 & 0.043 & 0.60 & 0.072 \\
\hline $\mathrm{Th}^{1}$ & $0.089-0.70$ & 57 & 100 & 86 & 0.176 & 18 & 0.0098 \\
\hline $\mathrm{Ti}^{1}$ & $43-226$ & 57 & 100 & 91 & 83 & 3,690 & 0.022 \\
\hline $\mathrm{Tl}^{1}$ & $0.005-0.683$ & 44 & 77 & 60 & 0.020 & 1.5 & 0.013 \\
\hline $\mathrm{Tm}$ & $0.004-0.032$ & 44 & 77 & 77 & 0.010 & --- & --- \\
\hline $\mathrm{U}^{1}$ & $0.020-0.36$ & 57 & 100 & 77 & 0.046 & --- & --- \\
\hline $\mathrm{V}^{1}$ & $0.78-7.20$ & 57 & 100 & 95 & 1.80 & 131 & 0.014 \\
\hline $\mathrm{W}^{1}$ & $<0.1-<1.0$ & 42 & 74 & 0 & --- & -- & --- \\
\hline Y & $0.34-6.75$ & 57 & 100 & 100 & 1.54 & 16 & 0.096 \\
\hline $\mathrm{Yb}^{1}$ & $0.023-0.179$ & 44 & 77 & 77 & 0.048 & 2.0 & 0.024 \\
\hline $\mathrm{Zn}$ & $128-2,710$ & 57 & 100 & 100 & 511 & 103 & 5.0 \\
\hline $\mathrm{Zr}^{1}$ & $0.381-1.202$ & 44 & 77 & 54 & 0.50 & -- & --- \\
\hline
\end{tabular}

${ }^{1}$ More than one lower limit of determination reported. The lowest reported value is shown. 
Table 7. Summary of chemical data for ash and 66 elements in 108 oak ash samples, Red Mountain, Arizona.

[All concentrations are in parts per million unless \% (percent) or ppb (parts per billion) is shown after the chemical symbol. Analytical methods are described in the associated data for this publication (Horton and others, 2020). ---, indicate no meaningful value. Values preceded by $<$ or $>$ are qualified values, which are less than or greater than, respectively, the value shown. Unqualified samples have no concentrations below the lower limit of determination or above the upper limit of determination. The ratio A/B gives an estimate of the relative enrichment $(>1.0)$ or depletion $(<1.0)$ of each element in the oak samples]

\begin{tabular}{|c|c|c|c|c|c|c|c|}
\hline $\begin{array}{l}\text { Element or } \\
\text { variable }\end{array}$ & Range of values & $\begin{array}{l}\text { Number } \\
\text { analyzed }\end{array}$ & $\begin{array}{l}\text { Percent analyzed } \\
\text { of } 108 \text { samples }\end{array}$ & $\begin{array}{l}\text { Percent unqualified } \\
\text { of } 108 \text { samples }\end{array}$ & $\begin{array}{l}\text { Median value } \\
\text { in ash }(\mathbf{A})\end{array}$ & $\begin{array}{l}\text { Median value } \\
\text { in soils (B) }\end{array}$ & $A / B$ ratio \\
\hline Ash (\%) & $1.31-9.50$ & 108 & 100 & 100 & 3.95 & --- & --- \\
\hline $\mathrm{Ag}^{1}$ & $0.05-2.89$ & 108 & 100 & 93 & 0.42 & 0.30 & 1.4 \\
\hline $\mathrm{A}^{1}$ & $300-3,600$ & 57 & 53 & 53 & 1,240 & 84,000 & 0.015 \\
\hline $\mathrm{As}^{1}$ & $<0.5-50.6$ & 108 & 100 & 94 & 5.0 & 34 & 0.47 \\
\hline $\mathrm{Ba}$ & $<50-4,040$ & 108 & 100 & 98 & 622 & 735 & 0.85 \\
\hline $\mathrm{Be}^{1}$ & $0.049-1.76$ & 108 & 100 & 85 & 0.178 & 1.0 & 0.18 \\
\hline $\mathrm{Bi}^{1}$ & $0.059-21$ & 108 & 100 & 90 & 0.159 & 1.0 & 0.16 \\
\hline $\mathrm{Br}$ & $<3-27$ & 16 & 15 & 14 & 14 & --- & --- \\
\hline $\mathrm{Co}$ & $0.95-64$ & 108 & 100 & 100 & 5.01 & 9.0 & 0.56 \\
\hline $\mathrm{Cr}^{1}$ & $0.7-31$ & 108 & 100 & 91 & 2.26 & 29 & 0.079 \\
\hline $\mathrm{Cs}^{1}$ & $0.4-588$ & 108 & 100 & 99 & 4.92 & --- & --- \\
\hline $\mathrm{Cu}$ & $24-506$ & 108 & 100 & 100 & 87 & 91 & 0.96 \\
\hline Dy & $0.068-2.81$ & 92 & 85 & 85 & 0.293 & --- & --- \\
\hline $\mathrm{Er}$ & $0.040-1.38$ & 92 & 85 & 85 & 0.139 & --- & --- \\
\hline $\mathrm{Eu}^{1}$ & $0.090-1.44$ & 108 & 100 & 89 & 0.223 & $<2.0$ & $>0.11$ \\
\hline $\mathrm{Fe}(\%)$ & $0.06-1.13$ & 108 & 100 & 100 & 0.21 & 4.62 & 0.045 \\
\hline $\mathrm{Ga}$ & $0.164-1.44$ & 92 & 85 & 85 & 0.458 & 23 & 0.020 \\
\hline In (ppb) & $2.819-23.1$ & 92 & 85 & 85 & 12.48 & --- & --- \\
\hline $\operatorname{Ir}(\mathrm{ppb})$ & $<5.0-<5.0$ & 16 & 15 & 0 & --- & --- & --- \\
\hline $\mathrm{K}(\%)^{2}$ & $1.67-9.04$ & 57 & 53 & 23 & $>6.60$ & 2.19 & $>3.0$ \\
\hline $\mathrm{La}$ & $0.82-26.7$ & 108 & 100 & 100 & 2.99 & 39 & 0.077 \\
\hline $\mathrm{Li}$ & $2.35-48$ & 92 & 85 & 85 & 10.23 & 19 & 0.54 \\
\hline Lu1 & $0.004-0.111$ & 92 & 85 & 85 & 0.014 & --- & --- \\
\hline $\operatorname{Mg}(\%)$ & $0.87-10.15$ & 108 & 100 & 100 & 3.20 & 0.47 & 6.8 \\
\hline $\mathrm{Mn}^{2}$ & $112-20,980$ & 108 & 100 & 98 & 5,025 & 571 & 8.8 \\
\hline $\mathrm{Mo}^{1}$ & $0.47-22.9$ & 108 & 100 & 92 & 1.6 & 4.0 & 0.39 \\
\hline $\mathrm{Na}(\%)$ & $0.03-0.36$ & 108 & 100 & 100 & 0.09 & 0.52 & 0.18 \\
\hline $\mathrm{Nb}^{1}$ & $0.019-0.140$ & 92 & 85 & 57 & 0.040 & 14 & 0.0029 \\
\hline $\mathrm{Nd}^{1}$ & $0.66-15.7$ & 108 & 100 & 86 & 2.43 & 34 & 0.071 \\
\hline
\end{tabular}


Table 7. Summary of chemical data for ash and 66 elements in 108 oak ash samples, Red Mountain, Arizona.

[All concentrations are in parts per million unless \% (percent) or ppb (parts per billion) is shown after the chemical symbol. Analytical methods are described in the associated data for this publication (Horton and others, 2020). ---, indicate no meaningful value. Values preceded by $<$ or $>$ are qualified values, which are less than or greater than, respectively, the value shown. Unqualified samples have no concentrations below the lower limit of determination or above the upper limit of determination. The ratio $\mathrm{A} / \mathrm{B}$ gives an estimate of the relative enrichment $(>1.0)$ or depletion $(<1.0)$ of each element in the oak samples]

\begin{tabular}{|c|c|c|c|c|c|c|c|}
\hline $\begin{array}{c}\text { Element or } \\
\text { variable }\end{array}$ & Range of values & $\begin{array}{c}\text { Number } \\
\text { analyzed }\end{array}$ & $\begin{array}{l}\text { Percent analyzed } \\
\text { of } 108 \text { samples }\end{array}$ & $\begin{array}{l}\text { Percent unqualified } \\
\text { of } 108 \text { samples }\end{array}$ & $\begin{array}{l}\text { Median value } \\
\text { in ash (A) }\end{array}$ & $\begin{array}{l}\text { Median value } \\
\text { in soils (B) }\end{array}$ & $A / B$ ratio \\
\hline $\mathrm{Ni}$ & $1.9-516$ & 108 & 100 & 100 & 35 & 15 & 2.3 \\
\hline $\mathrm{P}(\%)$ & $0.498-3.53$ & 16 & 15 & 15 & 1.72 & 0.080 & 22 \\
\hline $\mathrm{Pb}^{1}$ & $3.0-1,510$ & 108 & 100 & 98 & 13 & 112 & 0.12 \\
\hline $\operatorname{Pr}$ & $0.186-4.37$ & 92 & 85 & 85 & 0.774 & --- & --- \\
\hline $\mathrm{Rb}$ & $<15-1,910$ & 108 & 100 & 98 & 95.9 & --- & --- \\
\hline $\operatorname{Re}$ & $0.001-0.230$ & 92 & 85 & 85 & 5.25 & --- & --- \\
\hline $\mathrm{Sb}^{1}$ & $0.06-6.40$ & 108 & 100 & 96 & 0.18 & 3.0 & 0.06 \\
\hline $\mathrm{Sc}$ & $0.13-3.60$ & 57 & 53 & 53 & 0.41 & 12 & 0.034 \\
\hline $\mathrm{Se}^{1}$ & $0.37-4.92$ & 108 & 100 & 85 & 0.89 & --- & --- \\
\hline $\mathrm{Si}$ & $205-1,550$ & 41 & 38 & 38 & 479 & --- & --- \\
\hline $\mathrm{Sm}$ & $0.100-3.83$ & 108 & 100 & 100 & 0.59 & --- & --- \\
\hline $\mathrm{Sn}^{1}$ & $<1.0-1.77$ & 108 & 100 & 69 & 0.09 & --- & --- \\
\hline $\mathrm{Sr}$ & $197-5,580$ & 108 & 100 & 100 & 1,445 & 268 & 5.4 \\
\hline $\mathrm{Ta}^{1}$ & $<0.001-0.006$ & 108 & 100 & 32 & $<0.01$ & --- & --- \\
\hline $\mathrm{Tb}^{1}$ & $0.016-0.592$ & 108 & 100 & 85 & 0.059 & --- & --- \\
\hline $\mathrm{Te}^{1}$ & $0.014-0.109$ & 92 & 85 & 41 & $<0.10$ & 0.60 & $<0.17$ \\
\hline $\mathrm{Th}^{1}$ & $0.072-3.10$ & 108 & 100 & 93 & 0.201 & 18 & 0.011 \\
\hline $\mathrm{Ti}^{1}$ & $38-218$ & 108 & 100 & 97 & 86 & 3,690 & 0.023 \\
\hline $\mathrm{T}^{1}$ & $<0.010-2.40$ & 92 & 85 & 71 & 0.025 & 1.5 & 0.017 \\
\hline $\mathrm{Tm}$ & $0.005-0.147$ & 92 & 85 & 85 & 0.017 & --- & --- \\
\hline $\mathrm{U}^{1}$ & $0.023-1.02$ & 108 & 100 & 86 & 0.109 & --- & --- \\
\hline $\mathrm{V}^{1}$ & $0.84-7.00$ & 108 & 100 & 98 & 2.25 & 131 & 0.017 \\
\hline W & $<0.1-<1.0$ & 58 & 54 & 0 & --- & --- & --- \\
\hline Y & $0.40-16.8$ & 108 & 100 & 100 & 1.95 & 16 & 0.12 \\
\hline $\mathrm{Yb}^{1}$ & $0.028-0.905$ & 108 & 100 & 88 & 0.094 & 2.0 & 0.047 \\
\hline $\mathrm{Zn}$ & $58-4,040$ & 108 & 100 & 100 & 226 & 103 & 2.2 \\
\hline $\mathrm{Zr}^{1}$ & $0.380-1.37$ & 92 & 85 & 64 & 0.59 & --- & --- \\
\hline
\end{tabular}

${ }^{1}$ More than one lower limit of determination reported. The lowest reported value is shown.

${ }^{2}$ More than one upper limit of determination reported. The highest reported value is shown. 
Table 8. Summary of chemical data for ash and 66 elements in 68 juniper ash samples, Red Mountain, Arizona.

[All concentrations are in parts per million unless \% (percent) or ppb (parts per billion) is shown after the chemical symbol. Analytical methods are described in the text and in the associated data for this publication (Horton and others, 2020). ---, indicate no meaningful value. Values preceded by $<$ or $>$ are qualified values, which are less than or greater than, respectively, the value shown. Unqualified samples have no concentrations below the lower limit of determination or above the upper limit of determination. The ratio A/B gives an estimate of the relative enrichment $(>1.0)$ or depletion $(<1.0)$ of each element in the juniper samples]

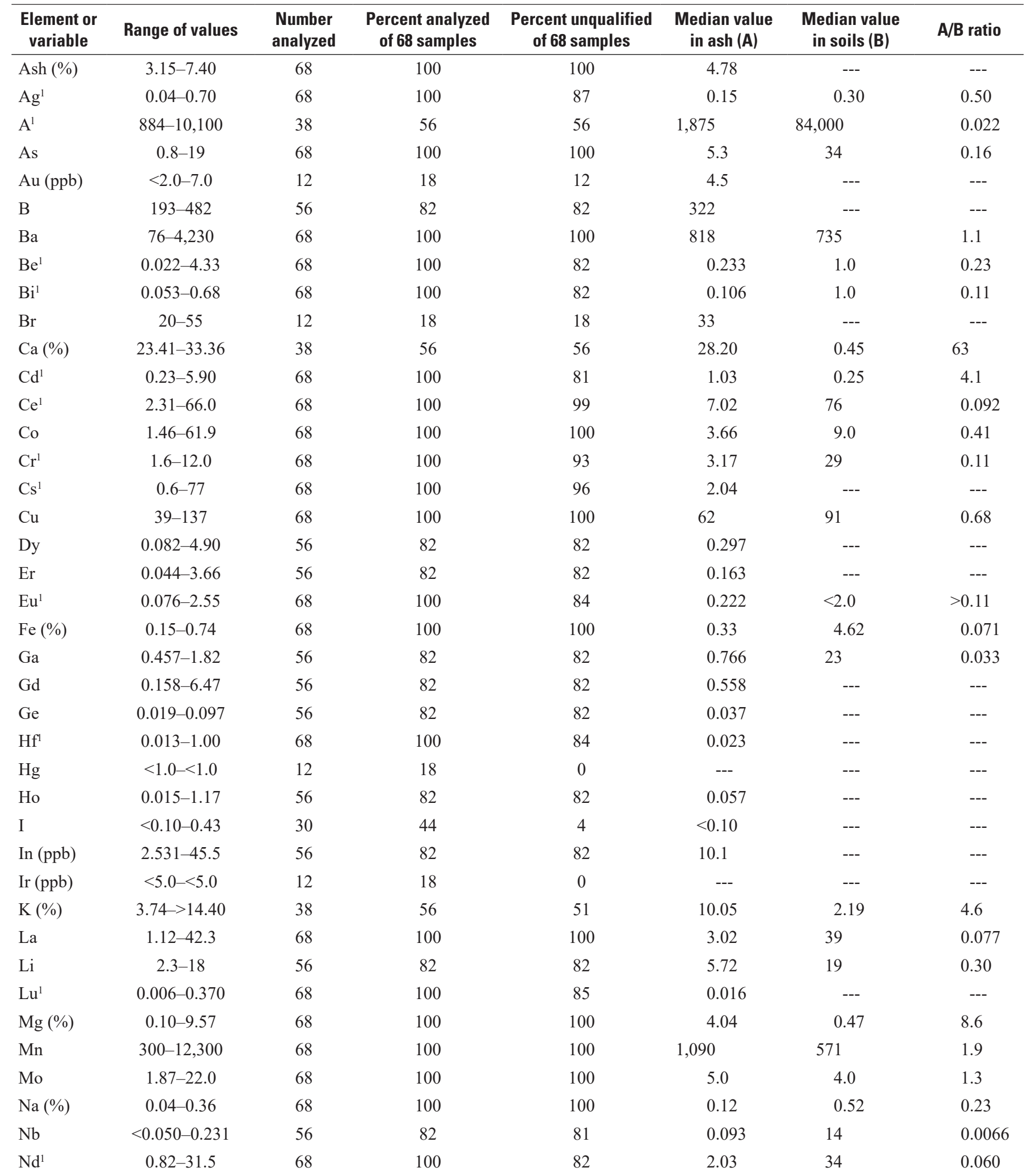


Table 8. Summary of chemical data for ash and 66 elements in 68 juniper ash samples, Red Mountain, Arizona.

[All concentrations are in parts per million unless \% (percent) or ppb (parts per billion) is shown after the chemical symbol. Analytical methods are described in the text and in the associated data for this publication (Horton and others, 2020). ---, indicate no meaningful value. Values preceded by $<$ or $>$ are qualified values, which are less than or greater than, respectively, the value shown. Unqualified samples have no concentrations below the lower limit of determination or above the upper limit of determination. The ratio A/B gives an estimate of the relative enrichment $(>1.0)$ or depletion $(<1.0)$ of each element in the juniper samples]

\begin{tabular}{|c|c|c|c|c|c|c|c|}
\hline $\begin{array}{l}\text { Element or } \\
\text { variable }\end{array}$ & Range of values & $\begin{array}{c}\text { Number } \\
\text { analyzed }\end{array}$ & $\begin{array}{l}\text { Percent analyzed } \\
\text { of } 68 \text { samples }\end{array}$ & $\begin{array}{l}\text { Percent unqualified } \\
\text { of } 68 \text { samples }\end{array}$ & $\begin{array}{l}\text { Median value } \\
\text { in ash (A) }\end{array}$ & $\begin{array}{l}\text { Median value } \\
\text { in soils (B) }\end{array}$ & $A / B$ ratio \\
\hline $\mathrm{Ni}$ & $3.0-174$ & 68 & 100 & 100 & 19 & 15 & 1.3 \\
\hline P (\%) & $0.763-2.44$ & 12 & 18 & 18 & 1.45 & 0.080 & 18 \\
\hline $\mathrm{Pb}$ & $1.8-62$ & 68 & 100 & 100 & 6.6 & 112 & 0.06 \\
\hline $\operatorname{Pr}$ & $0.231-8.25$ & 56 & 82 & 82 & 0.070 & --- & --- \\
\hline $\mathrm{Rb}^{1}$ & $<15-121$ & 68 & 100 & 96 & 31 & --- & --- \\
\hline $\operatorname{Re}$ & $0.067-12.92$ & 56 & 82 & 82 & 300 & --- & --- \\
\hline $\mathrm{Sb}^{1}$ & $0.08-5.00$ & 68 & 100 & 97 & 0.22 & 3.0 & 0.07 \\
\hline $\mathrm{Sc}$ & $0.40-3.00$ & 38 & 56 & 56 & 0.85 & 12 & 0.071 \\
\hline $\mathrm{Se}^{1}$ & $0.56-8.00$ & 68 & 100 & 84 & 1.06 & --- & --- \\
\hline $\mathrm{Si}$ & $773-2,940$ & 26 & 38 & 38 & 1,270 & --- & --- \\
\hline $\mathrm{Sm}$ & $0.153-5.60$ & 68 & 100 & 100 & 0.51 & --- & --- \\
\hline $\mathrm{Sn}^{1}$ & $<1.0-1.3$ & 68 & 100 & 53 & 1.00 & --- & --- \\
\hline $\mathrm{Sr}$ & $427-5,260$ & 68 & 100 & 100 & 2,175 & 268 & 8.1 \\
\hline $\mathrm{Ta}^{1}$ & $0.001-0.017$ & 68 & 100 & 47 & $<0.5$ & --- & --- \\
\hline $\mathrm{Tb}^{1}$ & $0.018-0.904$ & 68 & 100 & 82 & 0.060 & --- & --- \\
\hline $\mathrm{Te}^{1}$ & $0.004-0.16$ & 56 & 82 & 41 & $<0.10$ & 0.60 & $<0.17$ \\
\hline Th & $<0.200-1.80$ & 68 & 100 & 97 & 0.501 & 18 & 0.028 \\
\hline $\mathrm{Ti}$ & $92-700$ & 68 & 100 & 100 & 152 & 3,690 & 0.041 \\
\hline $\mathrm{Tl}^{1}$ & $0.007-0.135$ & 56 & 82 & 81 & 0.023 & 1.5 & 0.015 \\
\hline $\mathrm{Tm}$ & $0.006-0.445$ & 56 & 82 & 82 & 0.024 & --- & --- \\
\hline $\mathrm{U}^{1}$ & $0.028-0.60$ & 68 & 100 & 85 & 0.094 & --- & --- \\
\hline $\mathrm{V}^{1}$ & $1.51-19.0$ & 68 & 100 & 99 & 3.81 & 131 & 0.029 \\
\hline W & $<0.1-<1.0$ & 38 & 56 & 0 & $<0.1$ & --- & --- \\
\hline Y & $0.47-51$ & 68 & 100 & 100 & 2.50 & 16 & 0.16 \\
\hline $\mathrm{Yb}^{1}$ & $0.035-2.58$ & 68 & 100 & 88 & 0.113 & 2.0 & 0.057 \\
\hline $\mathrm{Zn}$ & $86-2,430$ & 68 & 100 & 100 & 202 & 103 & 2.0 \\
\hline $\mathrm{Zr}^{1}$ & $0.468-1.36$ & 56 & 82 & 68 & 0.62 & --- & --- \\
\hline
\end{tabular}

${ }^{1}$ More than one lower limit of determination reported. The lowest reported value is shown. 
and $\mathrm{Ag}$ (1.4) (table 7). For juniper, the elements accumulated are: $\mathrm{Ca}$ (63), $\mathrm{P}(18), \mathrm{Mg}(8.6), \mathrm{Sr}(8.1), \mathrm{K}$ (4.6), $\mathrm{Cd}(4.1), \mathrm{Zn}$ (2.0), Mn (1.9), Ni (1.3), Mo (1.3), and Ba (1.1) (table 8). These ratio values show that in addition to concentrating some of the deposit-related elements, the three plant species all tend to accumulate the common essential, nontoxic- and nondeposit-related elements, although to differing degrees.

The median concentration values in the ash (tables 6-8) indicate that the three plant species do not concentrate a given element to the same degree. For example, cadmium is about 10 times more concentrated in oak ash than in juniper ash, and at least 20 times more in oak ash than in mesquite ash. Zinc is more than twice as concentrated in mesquite ash than it is in the other two species. Similarly, cesium is about 8 times more concentrated in mesquite ash than in oak ash and at least 20 times more than in juniper ash. Other examples can be found. Clearly, these observations indicate that plant genetics must control the overall chemical uptake of different elements by each species.

\section{Distributions of Selected Elements in Rock and Soil Samples}

Maps related to the rock and soil chemistry (figs. 41-77) show the distributions for selected elements overlaid on a geologic base. The sample sites used for contouring are shown on each of the figures. The element distributions are shown using contours. Contours are shown with a solid line where the sample density is high. Where sample density is low, the contours are dashed.

Deposit-related elements with positive anomalies in both the rock and soil samples include $\mathrm{Ag}, \mathrm{As}, \mathrm{Bi}, \mathrm{Cu}, \mathrm{Fe}$, $\mathrm{Mo}, \mathrm{Pb}, \mathrm{Sb}, \mathrm{Te}$, and $\mathrm{Tl}$. Select elements exhibiting negative anomalies in both media include the deposit-related elements $\mathrm{Cd}, \mathrm{Co}$, and $\mathrm{Zn}$, and the mostly lithology-related elements $\mathrm{Ca}, \mathrm{K}, \mathrm{La}, \mathrm{Mg}, \mathrm{Mn}$, and $\mathrm{Na}$. Localized anomalies for deposit-related elements in the Tertiary indurated terrace gravels are caused by fragments of altered rock included in samples collected from this unit.

Outer Limit of Visible Alteration in Outcrops.-The boundary outlining the outer limit of visible strong alteration in rock samples defines an area, which helps to interpret anomaly sources (fig. 41). The area containing most of the altered samples is largely centered on the rhyolite tuff and quartz monzonite porphyry exposures but extends locally into the surrounding formations. The lateral extent at depth of alteration related to the Red Mountain PCD is not precisely known, but at the surface visible strong alteration extends more than $6 \mathrm{~km}$ in an east-west direction and about $4 \mathrm{~km}$ in a north-south direction (fig. 41).
There are also some scattered, small isolated altered areas outside of the altered rock boundary. Anomalies of any deposit-related elements in rock samples collected outside of this boundary (except for the few isolated, altered sites) probably do not have a source related to the hypogene $\mathrm{Cu}-\mathrm{Mo}$ deposit. This source is most likely contamination from material from past mining activity (Chaffee and others, 1981) in the region that has been dispersed by wind and (or) water.

Copper--The median values for copper in the rock and soil databases are 44 and 91 ppm, respectively (tables 4 and 5), indicating that copper has been concentrated during soil formation. The distribution of copper in rock samples is shown in figure 42 . The highest copper concentrations are found in two areas labeled "A" and "B," which are within the alteration boundary and clearly related to the hypogene $\mathrm{Cu}-\mathrm{Mo}$ deposit. Anomaly " $\mathrm{A}$ " is over the main exposure of the quartz monzonite porphyry. Anomaly " $\mathrm{B}$ " is farther to the east and is associated with the cluster of small outcrops of the same formation that is directly above the deep part of the hypogene deposit. The widespread anomaly labeled "C" is outside of the area of visible alteration and generally includes samples of visibly unaltered andesite collected along or near the Harshaw Creek drainage. A few samples from area "C" have copper concentrations exceeding $100 \mathrm{ppm}$. The source for these relatively high copper concentrations is not entirely clear, because obvious signs of alteration, such as veins, silicification, bleaching, or the presence of hydrothermal biotite or magnetite, are lacking.

The distribution of copper in soil samples (fig. 43) differs from that of copper in rock samples in that the highest soil concentrations are only present in the area surrounding the main quartz monzonite porphyry intrusive center (area "A" on fig. 42). The soil anomaly in area "B" is offset somewhat to the east of the quartz monzonite porphyry outcrops, possibly because of weathering-related chemical migration. The area of the anomaly labeled "C" on the rock map is also anomalous in general for the soils and is almost certainly caused by dispersion of sediments in the Harshaw Creek drainage contaminated by past mining activity (Chaffee and others, 1981).

Iron--Major rock-forming elements, such as iron, are difficult to contour because the range of values is more restricted than those of minor or trace elements. The overall distribution of this element reflects a combination of the bulk chemistry of the andesite and rhyolite tuff units and the hydrothermal introduction of iron, mainly in the form of pyrite, magnetite, and chalcopyrite. The median values for iron in the rock and soil databases are 3.54 and 4.62 percent, respectively (tables 4 and 5), indicating that iron has been concentrated during soil formation. The highest concentrations 

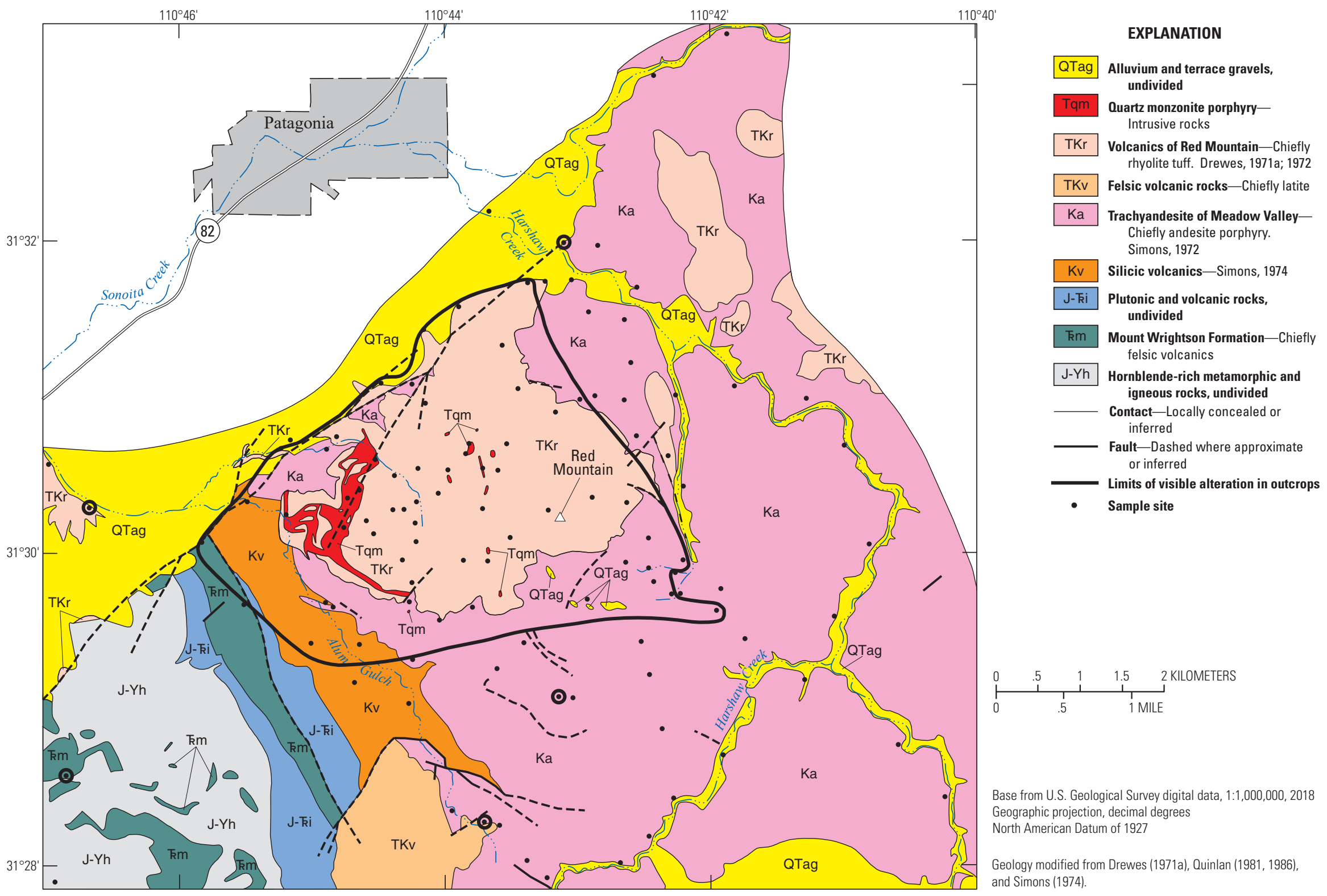

Figure 41. Sample locations and the outer limit of intense, visible alteration in outcrops. 


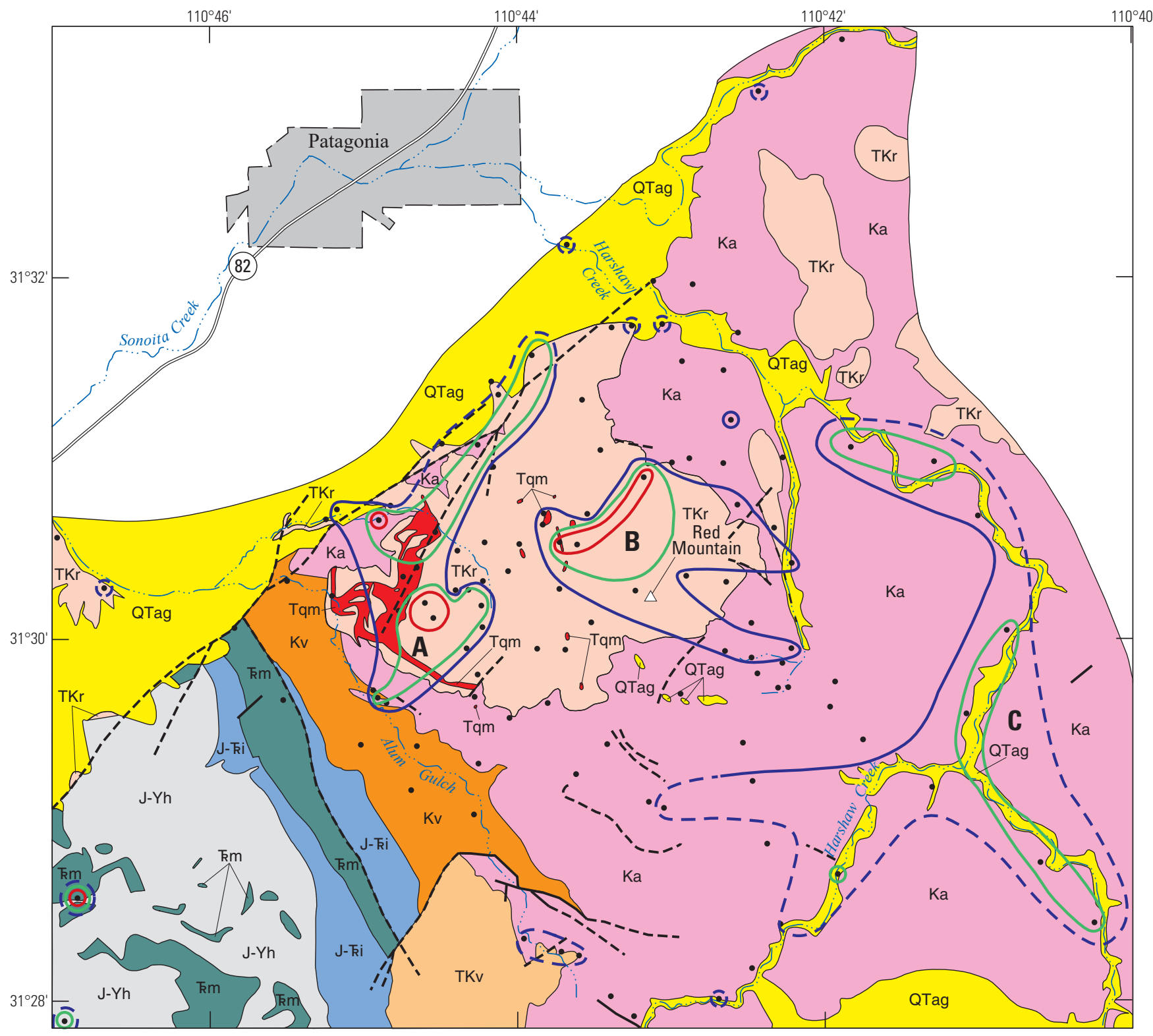

EXPLANATION

QTag Alluvium and terrace gravels, undivided

Quartz monzonite porphyry-

Intrusive rocks

TKr Volcanics of Red Mountain-Chiefly rhyolite tuff. Drewes, 1971a; 1972

TKv Felsic volcanic rocks-Chiefly latite

Ka Trachyandesite of Meadow ValleyChiefly andesite porphyry.$$
\text { Simons, } 1972
$$

Kv Silicic volcanics-Simons, 1974

- ki Plutonic and volcanic rocks,$$
\text { undivided }
$$

Mount Wrightson Formation-Chiefly felsic volcanics

$\mathrm{J}-\mathrm{Yh}$ Hornblende-rich metamorphic and igneous rocks, undivided

Contact-Locally concealed or

$$
\begin{aligned}
& \text { inferred } \\
& \text { intact-Locally }
\end{aligned}
$$

- Fault-Dashed where approximate or inferred

Distribution of copper in rock samples, in parts per million-Contours are show with a solid line where the sample density is high. Where sample density is low, the contours are dashed

$\longrightarrow \quad 100$

- Sample site

\section{A, B Identify strongly anomalous areas}

C Anomaly at area probably represents contamination from past mining in the region

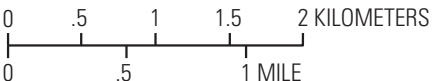

Base from U.S. Geological Survey digital data, 1:1,000,000, 2018 Geographic projection decimal degrees North American Datum of 1927

Geology modified from Drewes (1971a), Quinlan (1981, 1986), and Simons (1974).

Figure 42. Distribution of copper in rock samples. 


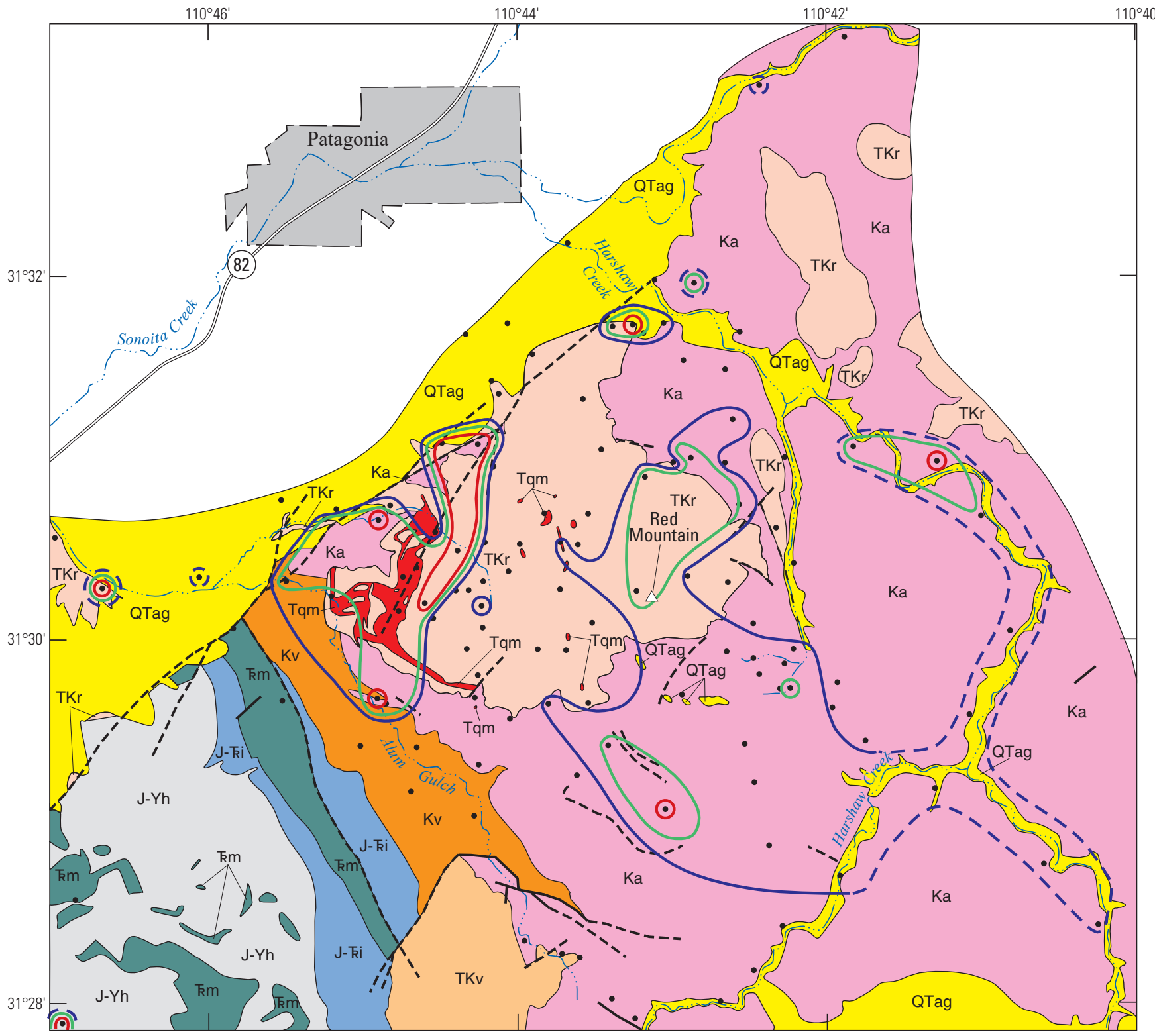

\section{EXPLANATION}

QTag Alluvium and terrace gravels, undivided

Quartz monzonite porphyryIntrusive rocks

TKr Volcanics of Red Mountain-Chiefly rhyolite tuff. Drewes, 1971a; 1972

TKv Felsic volcanic rocks-Chiefly latite

Ka Trachyandesite of Meadow ValleyChiefly andesite porphyry. Simons, 1972

Kv Silicic volcanics-Simons, 1974

$\mathrm{J}-\mathrm{Ki}$ Plutonic and volcanic rocks, undivided

Mount Wrightson Formation-Chiefly felsic volcanics

$\mathrm{J}-\mathrm{Yh}$ Hornblende-rich metamorphic and igneous rocks, undivided Contact-Locally concealed or inferred

Fault—Dashed where approximate or inferred

Distribution of copper in soil samples, in parts per million-Contours are shown with a solid line where the sample density is high. Where sample density is low, the

$\begin{array}{r}200 \\ \hline \quad 150 \\ \hline\end{array}$

Sample site

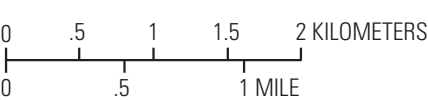

Base from U.S. Geological Survey digital data, 1:1,000,000, 2018 Geographic projection, decimal degrees

North American Datum of 1927

Geology modified from Drewes (1971a), Quinlan $(1981,1986)$ and Simons (1974).

Figure 43. Distribution of copper in soil samples. 


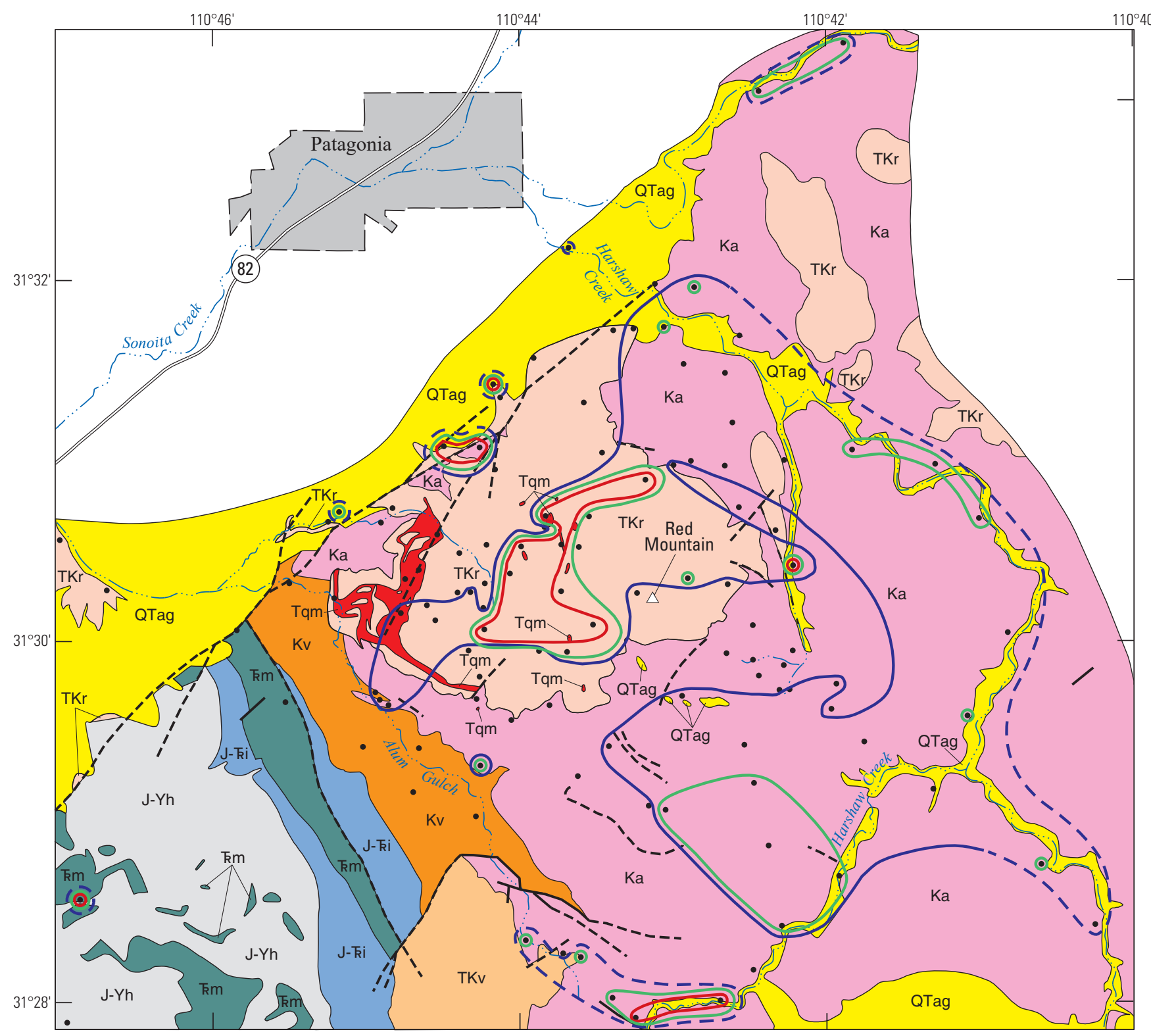

\section{EXPLANATION}

QTag Alluvium and terrace gravels, undivided

Quartz monzonite porphyryIntrusive rocks

TKr Volcanics of Red Mountain - Chiefly rhyolite tuff. Drewes, 1971a; 1972

TKv Felsic volcanic rocks-Chiefly latite

Ka Trachyandesite of Meadow ValleyChiefly andesite porphyry. Simons, 1972

Kv Silicic volcanics-Simons, 1974

$\mathrm{J}$ - $\mathrm{ki}$ Plutonic and volcanic rocks, undivided

Mount Wrightson Formation-Chiefly felsic volcanics

$\mathrm{J}-\mathrm{Yh}$ Hornblende-rich metamorphic and

$$
\text { igneous rocks, undivided }
$$

Contact-Locally concealed or inferred

Fault-Dashed where approximate or inferred

Distribution of iron in rock samples, in percent-Contours are shown with a solid line where the sample density is high. Where sample density is low, the contours are dashed

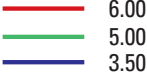

- Sample site

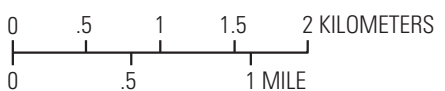

Base from U S. Geological Survey digital data 111,000,000, 2018 Geographic projection, decimal degrees North American Datum of 1927 and Simons (1974).

Figure 44. Distribution of iron in rock samples. 


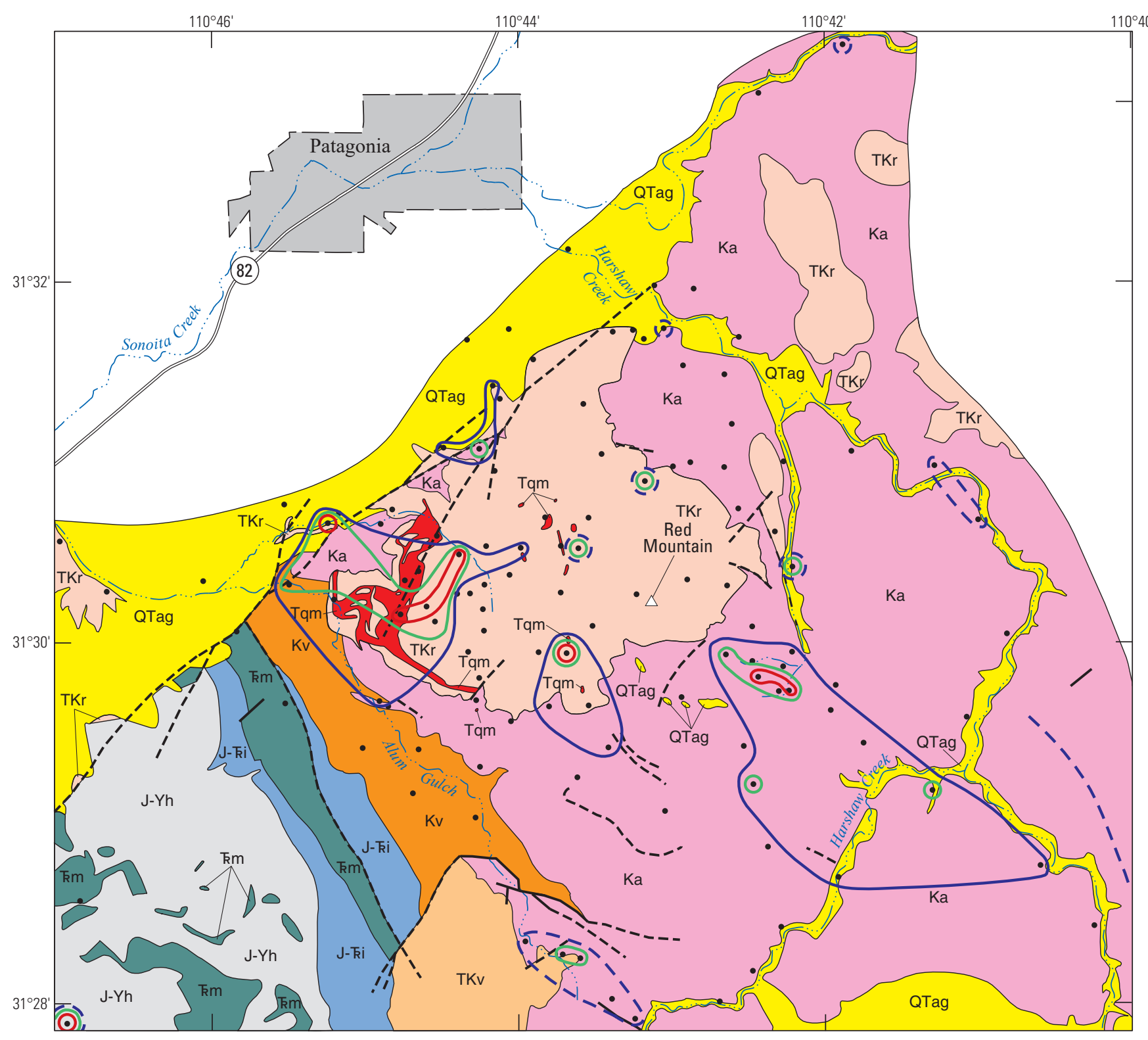

Figure 45. Distribution of iron in soil samples.

\section{EXPLANATION}

QTag Alluvium and terrace gravels, undivided

Quartz monzonite porphyryIntrusive rocks

TKr Volcanics of Red Mountain-Chiefly rhyolite tuff. Drewes, 1971a; 1972

TKv Felsic volcanic rocks-Chiefly latite

$\mathrm{Ka}$ Trachyandesite of Meadow ValleyChiefly andesite porphyry. Simons, 1972

Kv Silicic volcanics-Simons, 1974

$\mathrm{J}$ - Ki Plutonic and volcanic rocks, undivided

Mount Wrightson Formation-Chiefly felsic volcanics

$\mathrm{J}-\mathrm{Yh}$ Hornblende-rich metamorphic and igneous rocks, undivided Contact-Locally concealed or inferred

— Fault—Dashed where approximate or inferred

Distribution of iron in soil samples, in percent-Contours are shown with a solid line where the sample density is high. Where sample density is low, the contours are dashed

$\begin{array}{r}-00 \\ -5.00 \\ \hline\end{array}$

$\longrightarrow \begin{array}{r}6.00 \\ 5.00\end{array}$

- Sample site

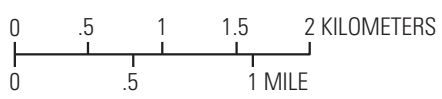

Base from U.S. Geological Survey digital data, 1:1,000,000, 2018 Geographic projection, decimal degrees

North American Datum of 1927

Geology modified from Drewes (1971a), Quinlan $(1981,1986)$, and Simons (1974). 


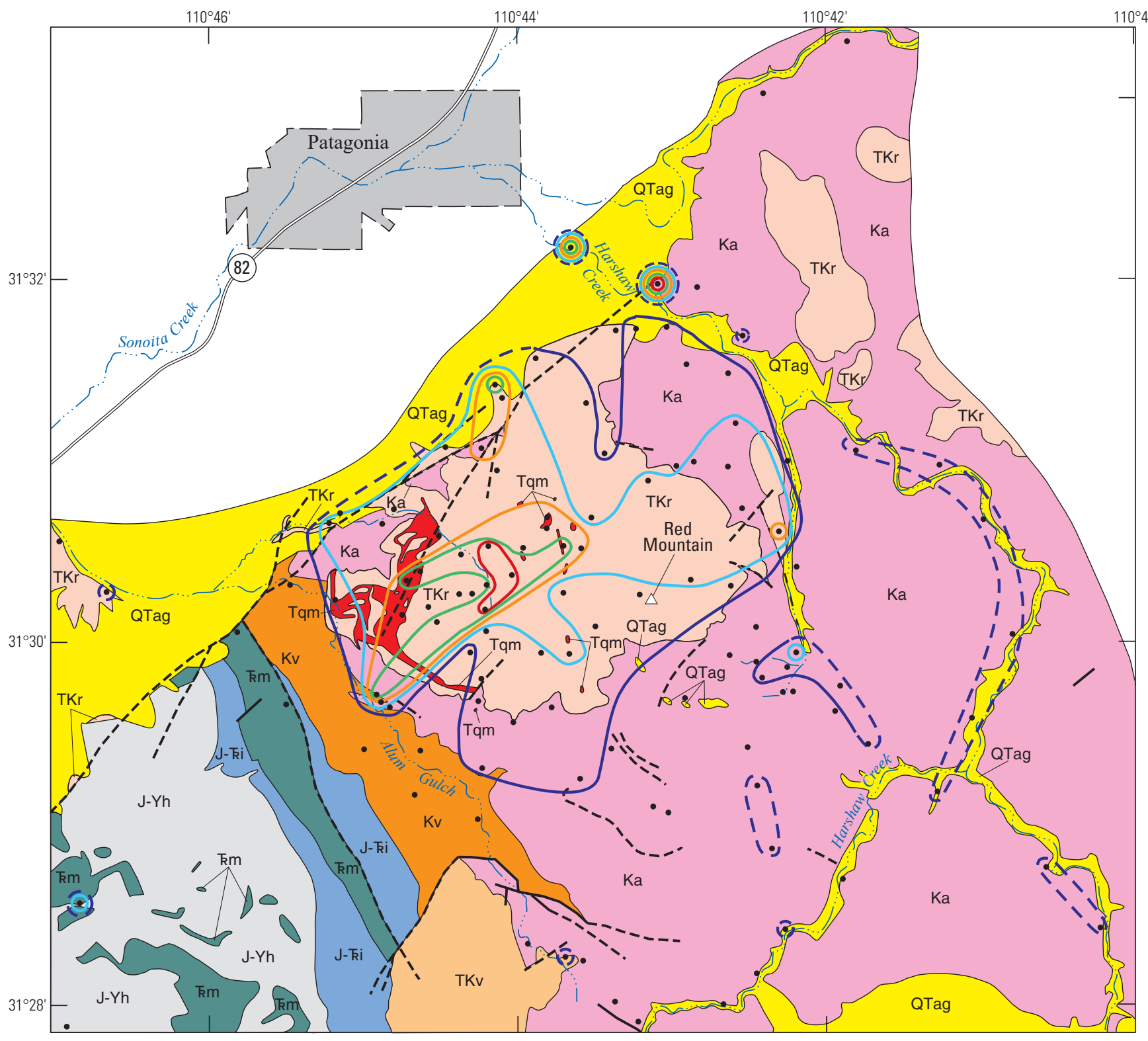

QTag Alluvium and terrace gravels, undivided

Quartz monzonite porphyryIntrusive rocks

TKr Volcanics of Red Mountain-Chiefly rhyolite tuff. Drewes, 1971a; 1972

TKv Felsic volcanic rocks-Chiefly latite

Ka Trachyandesite of Meadow ValleyChiefly andesite porphyry. Simons, 1972

Kv Silicic volcanics-Simons, 1974

$\mathrm{J}-\mathrm{ki}$ Plutonic and volcanic rocks, undivided

Mount Wrightson Formation-Chiefly felsic volcanics

$\mathrm{J}-\mathrm{Yh}$ Hornblende-rich metamorphic and

$$
\text { igneous rocks, undivided }
$$

Contact-Locally concealed or inferred

—_ Fault—Dashed where approximate or inferred

Distribution of molybdenum in rock samples, in parts per million-Contours are show with a solid line where the sample density is high. Where sample density is low, the contours are dashed

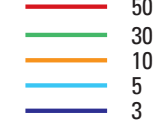

50
30

- Sample site

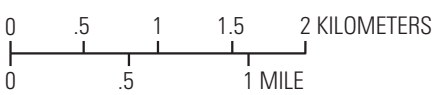

Base from U.S. Geological Survey digital data, 1:1,000,000, 2018 Geographic projection, decimal degrees orth American Datum of 1927

Figure 46. Distribution of molybdenum in rock samples. 


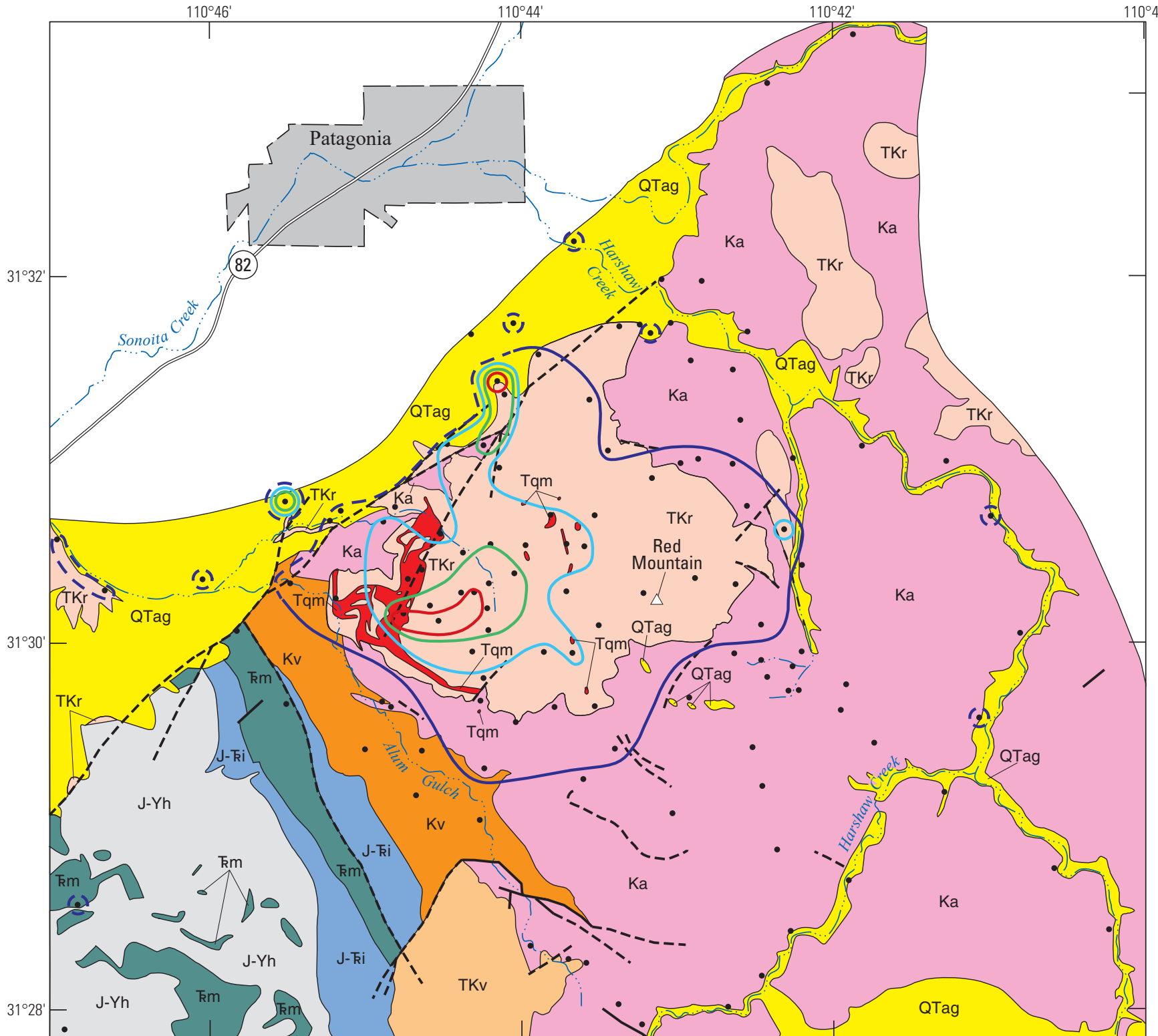

Figure 47. Distribution of molybdenum in soil samples.

\section{EXPLANATION}

QTag Alluvium and terrace gravels. undivided

Quartz monzonite porphyryIntrusive rocks

TKr Volcanics of Red Mountain-Chiefly rhyolite tuff. Drewes, 1971a; 1972

TKv Felsic volcanic rocks-Chiefly latite

$\mathrm{Ka}$ Trachyandesite of Meadow ValleyChiefly andesite porphyry. Simons, 1972

Kv Silicic volcanics-Simons, 1974

$\mathrm{J}-\mathrm{ki}$ Plutonic and volcanic rocks, undivided

Mount Wrightson Formation-Chiefly felsic volcanics

$\mathrm{J}-\mathrm{Yh}$ Hornblende-rich metamorphic and igneous rocks, undivided Contact-Locally concealed or

inferred
Fault-Dashed where approximate or inferred

Distribution of molybdenum in soil samples, in parts per million-Contours are shown with a solid line where the sample density is high. Where sample density is low, the contours are dashed

$\begin{array}{r}-50 \\ -\quad 20 \\ \hline\end{array}$

$\begin{array}{ll}- & 10 \\ & 4\end{array}$

- Sample site

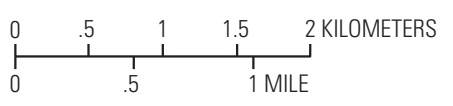

Base from U.S. Geological Survey digital data, 1:1,000,000, 2018 Geographic projection, decimal degrees North American Datum of 1927

Geology modified from Drewes (1971a), Quinlan $(1981,1986)$ and Simons (1974). 


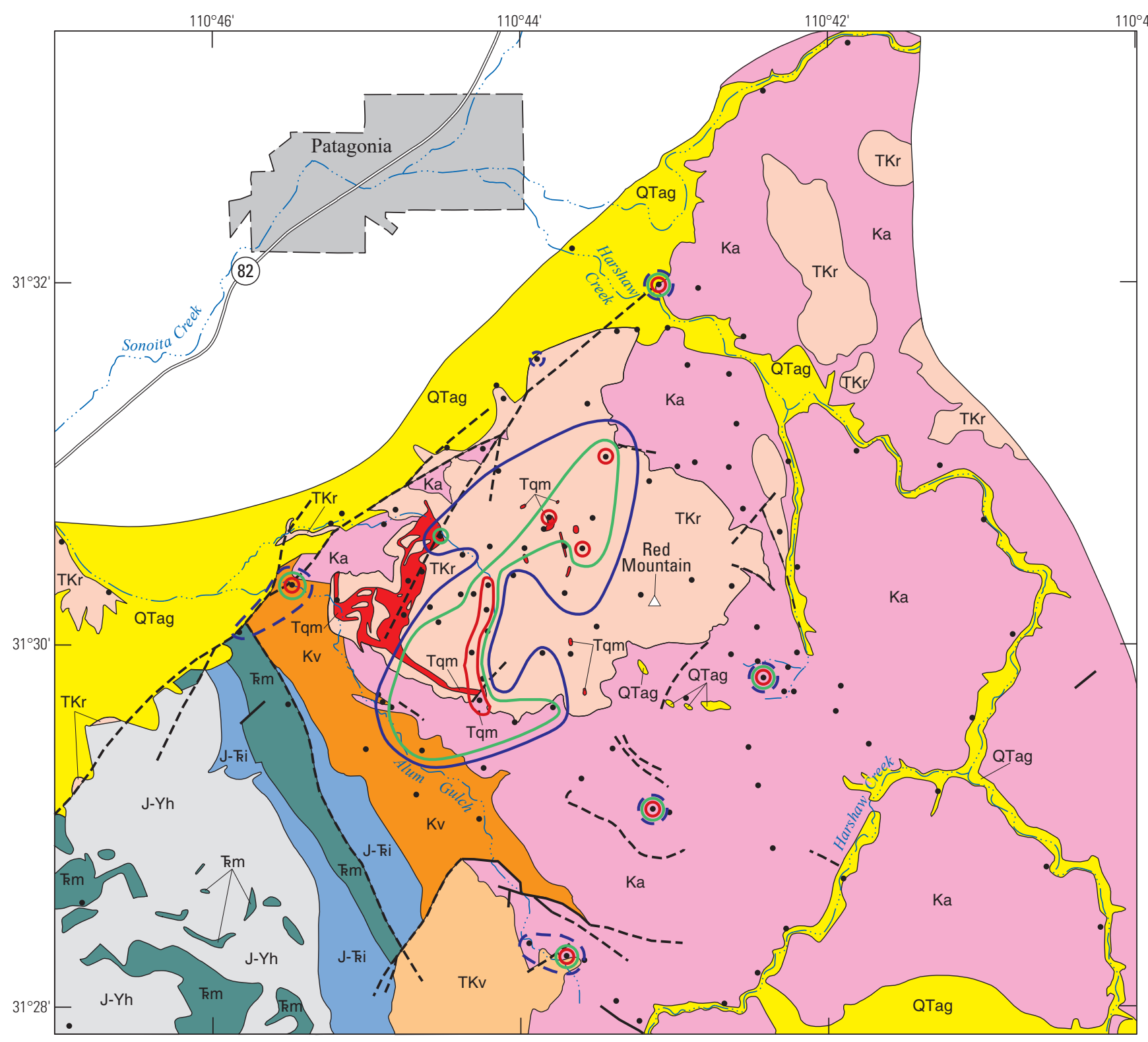

\section{EXPLANATION}

QTag Alluvium and terrace gravels, undivided

Quartz monzonite porphyryIntrusive rocks

TKr Volcanics of Red Mountain - Chiefly rhyolite tuff. Drewes, 1971a; 1972

TKv Felsic volcanic rocks-Chiefly latite

$\mathrm{Ka}$ Trachyandesite of Meadow ValleyChiefly andesite porphyry. Simons, 1972

Kv Silicic volcanics-Simons, 1974

$\mathrm{J}-\mathrm{ki}$ Plutonic and volcanic rocks, undivided

Mount Wrightson Formation-Chiefly felsic volcanics

$\mathrm{J}$-Yh Hornblende-rich metamorphic and igneous rocks, undivided Contact-Locally concealed or inferred

ault-Dashed where approximate or inferred

Distribution of silver in rock samples, in parts per million-Contours are shown with a solid line where the sample density is high. Where sample density is

$\begin{array}{r}1.0 \\ \hline\end{array} 0.5$ the contours are dashed

0.5
-

- Sample site

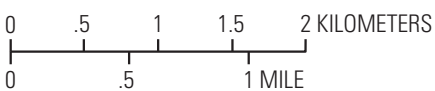

Base from U S. Geological Survey digital data, 1:1,000,000, 2018 Geographic projection, decimal degrees

Geology modified from Drewes (1971a), Quinlan (1981, 1986 and Simons (1974)

Figure 48. Distribution of silver in rock samples. 


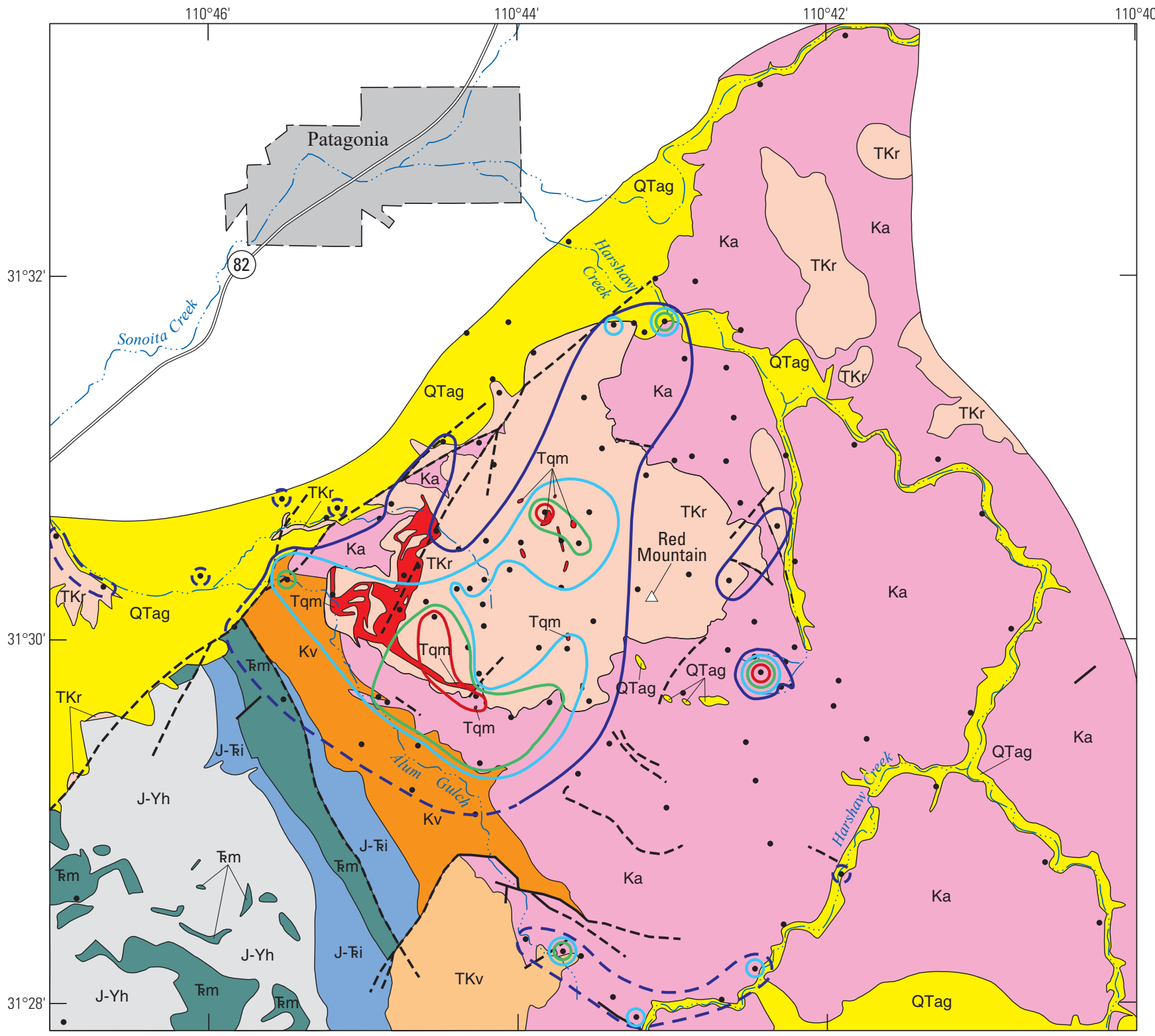

\section{EXPLANATION}

QTag Alluvium and terrace gravels, undivided

Quartz monzonite porphyryIntrusive rocks

TKr Volcanics of Red Mountain-Chiefly rhyolite tuff. Drewes, 1971a; 1972

TKv Felsic volcanic rocks-Chiefly latite

$\mathrm{Ka}$ Trachyandesite of Meadow ValleyChiefly andesite porphyry. Simons, 1972

Kv Silicic volcanics-Simons, 1974

$\mathrm{J}$ - $\mathrm{ki}$ Plutonic and volcanic rocks undivided

Mount Wrightson Formation-Chiefly felsic volcanics

$\mathrm{J}-\mathrm{Yh}$ Hornblende-rich metamorphic and igneous rocks, undivide Contact-Locally concealed or inferred

ault-Dashed where approximate or inferred

Distribution of silver in soil samples, in parts per million-Contours are shown with a solid line where the sample density is high. Where sample density is low the contours are dashed

$\begin{array}{r}-3.0 \\ \hline\end{array}$

1.0
-0.3

- Sample site

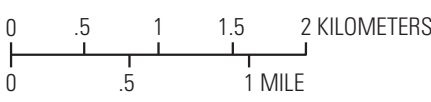

Base from U.S. Geological Survey digital data, 1:1,000,000, 2018 Geographic projection, decimal degrees

North American Datum of 1927

Geology modified from Drewes (1971a), Quinlan $(1981,1986)$ and Simons (1974).

Figure 49. Distribution of silver in soil samples. 


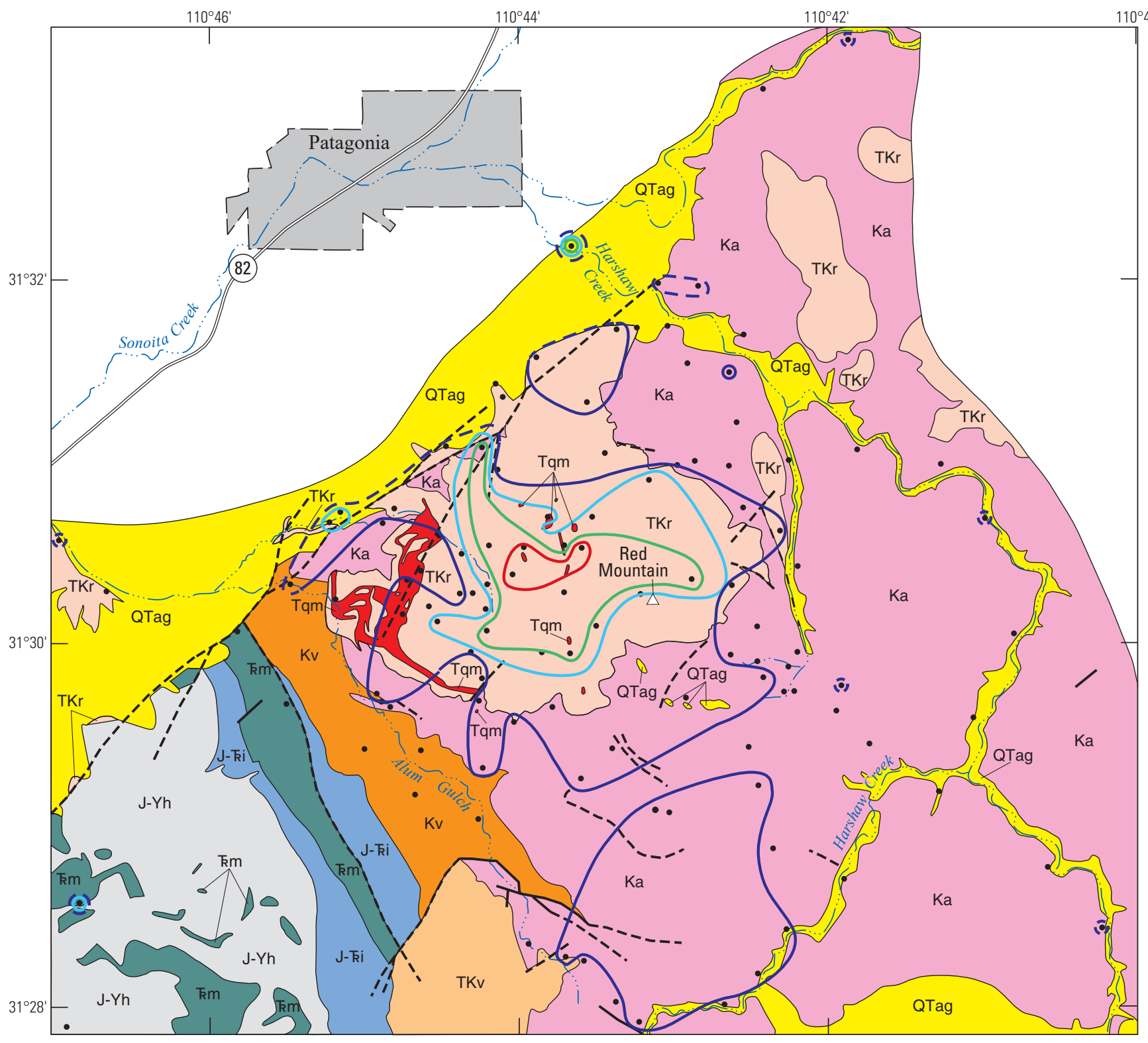

EXPLANATION

QTag Alluvium and terrace gravels, undivided

Quartz monzonite porphyryIntrusive rocks

TKr Volcanics of Red Mountain - Chiefly rhyolite tuff. Drewes, 1971a; 1972

TKv Felsic volcanic rocks-Chiefly latite

Ka Trachyandesite of Meadow ValleyChiefly andesite porphyry. Simons, 1972

Kv Silicic volcanics-Simons, 1974

$\mathrm{J}-\mathrm{ki}$ Plutonic and volcanic rocks, undivided

Mount Wrightson Formation-Chiefly felsic volcanics

$\mathrm{J}-\mathrm{Yh}$ Hornblende-rich metamorphic and igneous rocks, undivided Contact-Locally concealed or inferred

Fault-Dashed where approximate or inferred

Distribution of arsenic in rock samples, in parts per million-Contours are shown with a solid line where the sample density is high. Where sample density is low, the contours are dashed

$\begin{array}{r}-300 \\ -\quad 100 \\ \hline\end{array}$

-50
$-\quad 10$

- Sample site

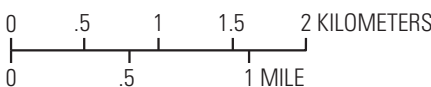

Base from U.S. Geological Survey digital data, 1:1,000,000, 2018 Geographic projection, decimal degrees North American Datum of 1927

Figure 50. Distribution of arsenic in rock samples. 


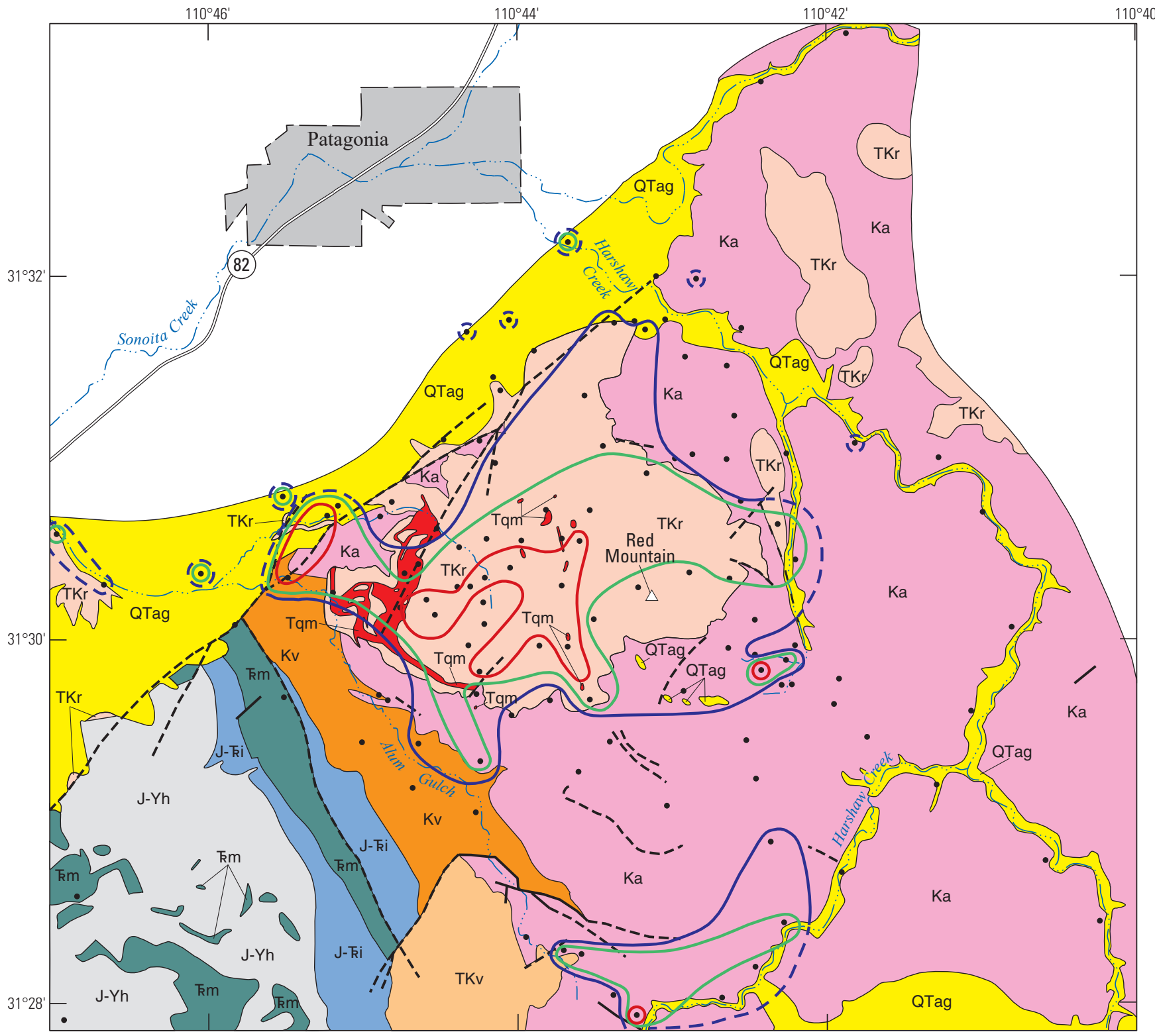

\section{EXPLANATION}

QTag Alluvium and terrace gravels, undivided

Quartz monzonite porphyryIntrusive rocks

TKr Volcanics of Red Mountain-Chiefly rhyolite tuff. Drewes, 1971a; 1972

TKv Felsic volcanic rocks-Chiefly latite

Ka Trachyandesite of Meadow ValleyChiefly andesite porphyry. Simons, 1972

Kv Silicic volcanics-Simons, 1974

$\mathrm{J}-\mathrm{ki}$ Plutonic and volcanic rocks, undivided

Mount Wrightson Formation-Chiefly felsic volcanics

$\mathrm{J}-\mathrm{Yh}$ Hornblende-rich metamorphic and igneous rocks, undivide Contact-Locally concealed or inferred

Fault-Dashed where approximate or inferred

Distribution of arsenic in soil samples, in parts per million-Contours are shown with a solid line where the sample density is high. Where sample density is low, the contours are dashed

$\begin{array}{cc}- & 100 \\ & 50\end{array}$

- Sample site

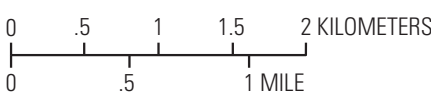

Base from U.S. Geological Survey digital data, 1:1,000,000, 2018 Geographic projection, decimal degrees North American Datum of 1927

Geology modified from Drewes (1971a), Quinlan (1981, 1986) and Simons (1974).

Figure 51. Distribution of arsenic in soil samples. 


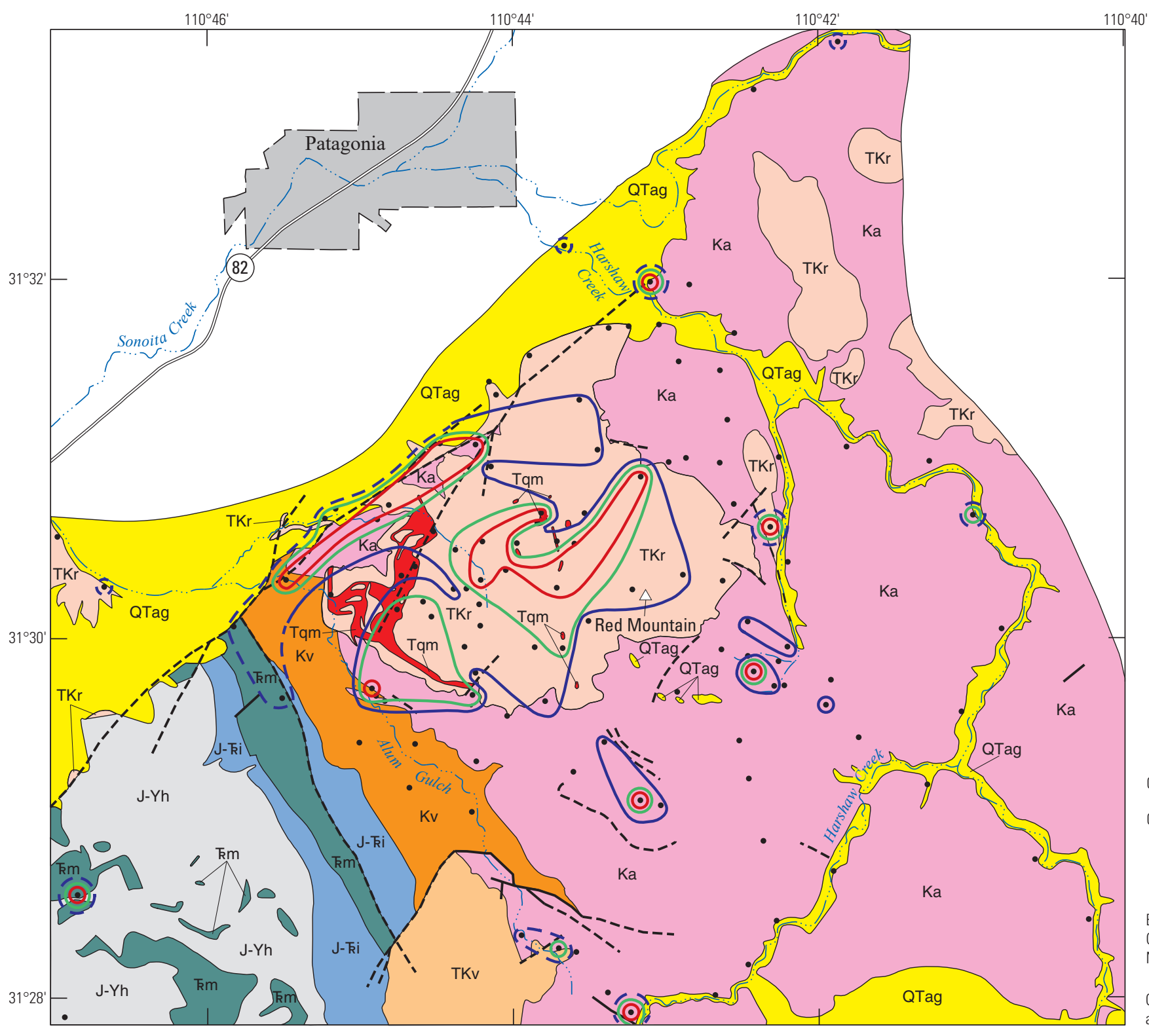

EXPLANATION

QTag Alluvium and terrace gravels, undivided

Quartz monzonite porphyryIntrusive rocks

TKr Volcanics of Red Mountain - Chiefly rhyolite tuff. Drewes, 1971a; 1972

TKv Felsic volcanic rocks-Chiefly latite

Ka Trachyandesite of Meadow ValleyChiefly andesite porphyry. Simons, 1972

Kv Silicic volcanics-Simons, 1974

$\mathrm{J}-\mathrm{ki}$ Plutonic and volcanic rocks, undivided

Mount Wrightson Formation-Chiefly felsic volcanics

$\mathrm{J}-\mathrm{Yh}$ Hornblende-rich metamorphic and igneous rocks, undivided Contact-Locally concealed or inferred

_ Fault-Dashed where approximate or inferred

Distribution of antimony in rock samples, in parts per million-Contours are shown with a solid line where the sample density is high. Where sample density is low, the contours are dashed

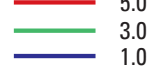

- Sample site

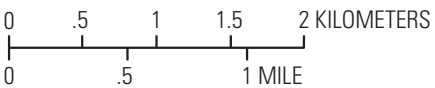

Base from U S. Geological Survey digital data, 11:000,000, 2018 Geographic projection, decimal degrees North American Datum of 1927

Figure 52. Distribution of antimony in rock samples. 


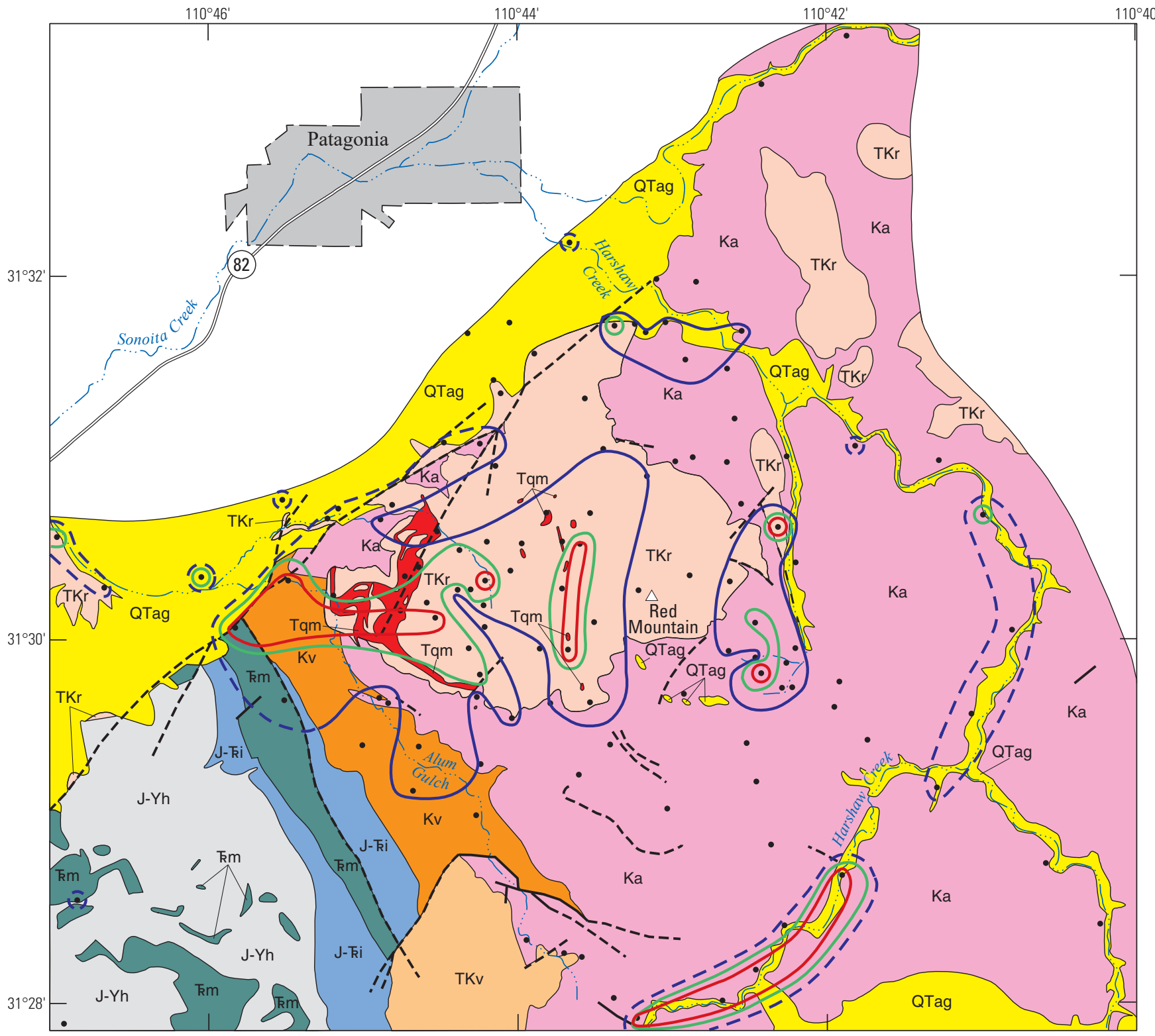

\section{EXPLANATION}

QTag Alluvium and terrace gravels, undivided

Quartz monzonite porphyryIntrusive rocks

TKr Volcanics of Red Mountain-Chiefly rhyolite tuff. Drewes, 1971a; 1972

TKv Felsic volcanic rocks-Chiefly latite

$\mathrm{Ka}$ Trachyandesite of Meadow ValleyChiefly andesite porphyry. Simons, 1972

Kv Silicic volcanics-Simons, 1974

$\mathrm{J}$ - $\mathrm{ki}$ Plutonic and volcanic rocks, undivided

Mount Wrightson Formation-Chiefly felsic volcanics

$\mathrm{J}-\mathrm{Yh}$ Hornblende-rich metamorphic and igneous rocks, undivide Contact-Locally concealed or inferred

Fault-Dashed where approximate or inferred

Distribution of antimony in soil samples, in parts per million-Contours are shown parts per million-Contours are show
with a solid line where the sample density is high. Where sample density is low, the contours are dashed

\begin{tabular}{ll}
- & 10 \\
\hline & 6.0
\end{tabular}

- Sample sit

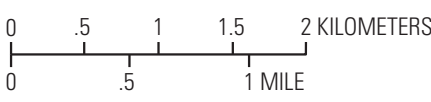

Base from U.S. Geological Survey digital data, 1:1,000,000, 2018 Geographic projection, decimal degrees

North American Datum of 1927

Geology modified from Drewes (1971a), Quinlan $(1981,1986)$ and Simons (1974).

Figure 53. Distribution of antimony in soil samples 


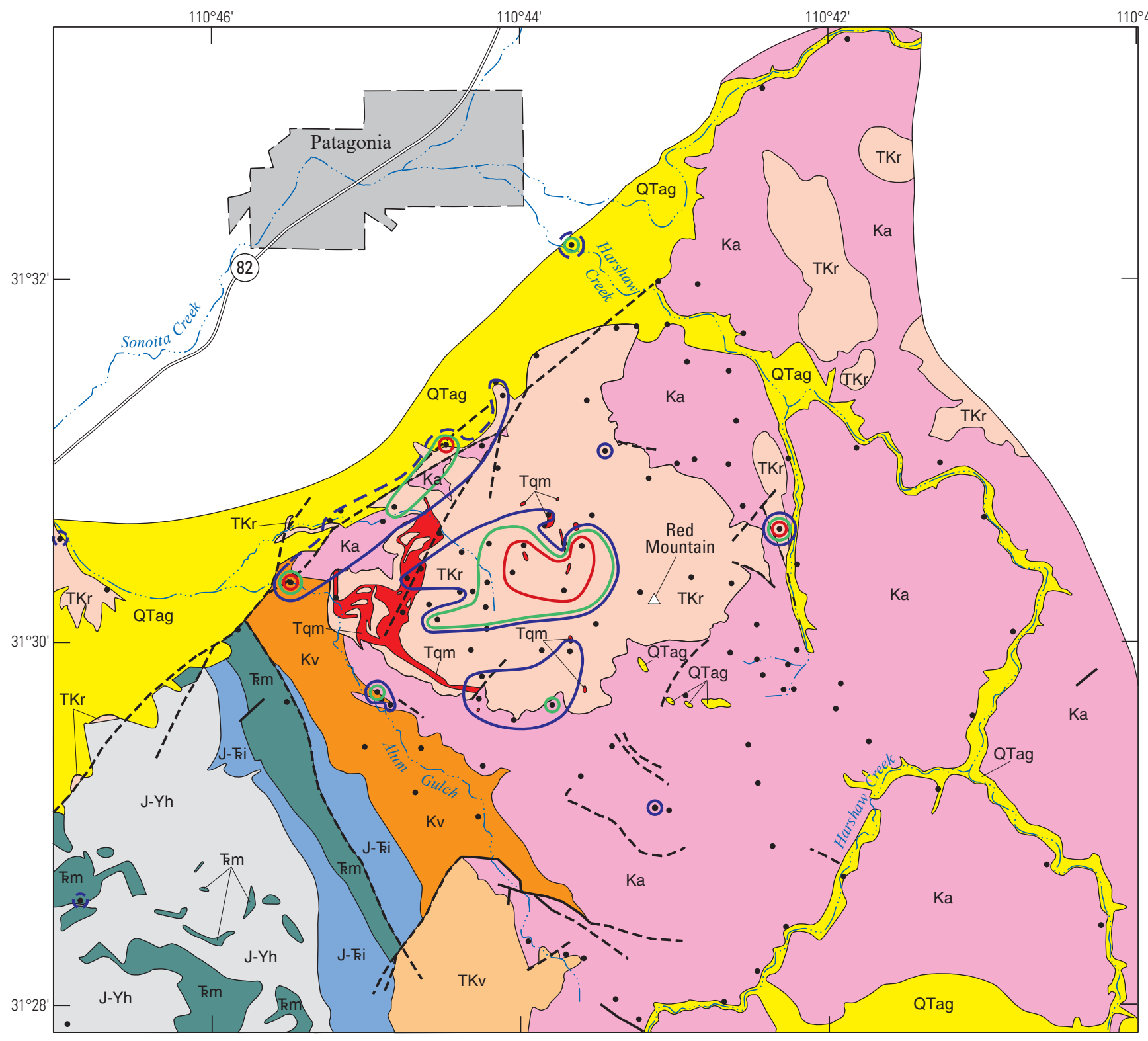

EXPLANATION

QTag Alluvium and terrace gravels, undivided

Quartz monzonite porphyryIntrusive rocks

TKr Volcanics of Red Mountain-Chiefly rhyolite tuff. Drewes, 1971a; 1972

TKv Felsic volcanic rocks-Chiefly latite

$\mathrm{Ka}$ Trachyandesite of Meadow ValleyChiefly andesite porphyry. Simons, 1972

Kv Silicic volcanics-Simons, 1974

$\mathrm{J}-\mathrm{ki}$ Plutonic and volcanic rocks, undivided

Mount Wrightson Formation-Chiefly felsic volcanics

J-Yh Hornblende-rich metamorphic and igneous rocks, undivided Contact-Locally concealed or inferred

ault-Dashed where approximate or inferred

Distribution of bismuth in rock samples, in parts per million-Contours are shown with a solid line where the sample density is high. Where sample density is low, the contours are dashed

\begin{tabular}{r}
$\square$ \\
\hline \\
$\quad$ \\
1.0
\end{tabular}

- Sample site

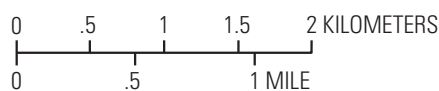

Base from U.S. Geological Survey digital data, 1:1,000,000, 2018 Geographic projection, decimal degrees North American Datum of 1927 and Simons (1974)

Figure 54. Distribution of bismuth in rock samples. 


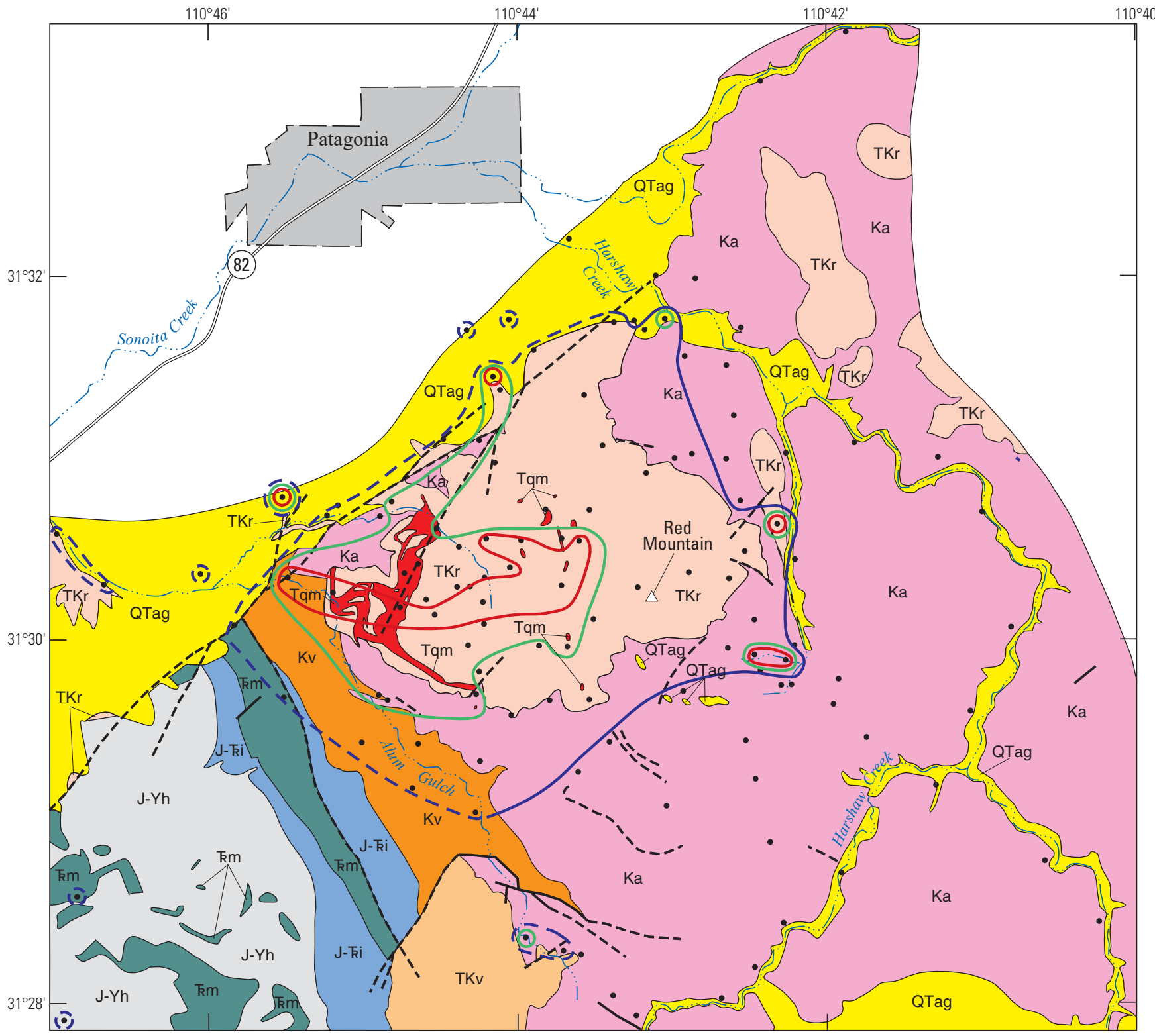

\section{EXPLANATION}

QTag Alluvium and terrace gravels, undivided

Quartz monzonite porphyryIntrusive rocks

TKr Volcanics of Red Mountain-Chiefly rhyolite tuff. Drewes, 1971a; 1972

TKv Felsic volcanic rocks-Chiefly latite

Ka Trachyandesite of Meadow ValleyChiefly andesite porphyry. Simons, 1972

Kv Silicic volcanics-Simons, 1974

$\mathrm{J}-\mathrm{ki}$ Plutonic and volcanic rocks, undivided

Mount Wrightson Formation-Chiefly felsic volcanics

$\mathrm{J}-\mathrm{Yh}$ Hornblende-rich metamorphic and igneous rocks, undivide Contact-Locally concealed or inferred

Fault-Dashed where approximate or inferred

Distribution of bismuth in soil samples, in parts per million-Contours are shown with a solidline where the sample density is high. Where sample density is low, the contours are dashed

$\begin{array}{r}5.0 \\ \hline \\ \hline\end{array} .0$

- Sample site

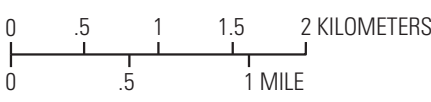

Base from U.S. Geological Survey digital data, 1:1,000,000, 2018 Geographic projection, decimal degrees North American Datum of 1927

Geology modified from Drewes (1971a), Quinlan $(1981,1986)$ and Simons (1974).

Figure 55. Distribution of bismuth in soil samples. 


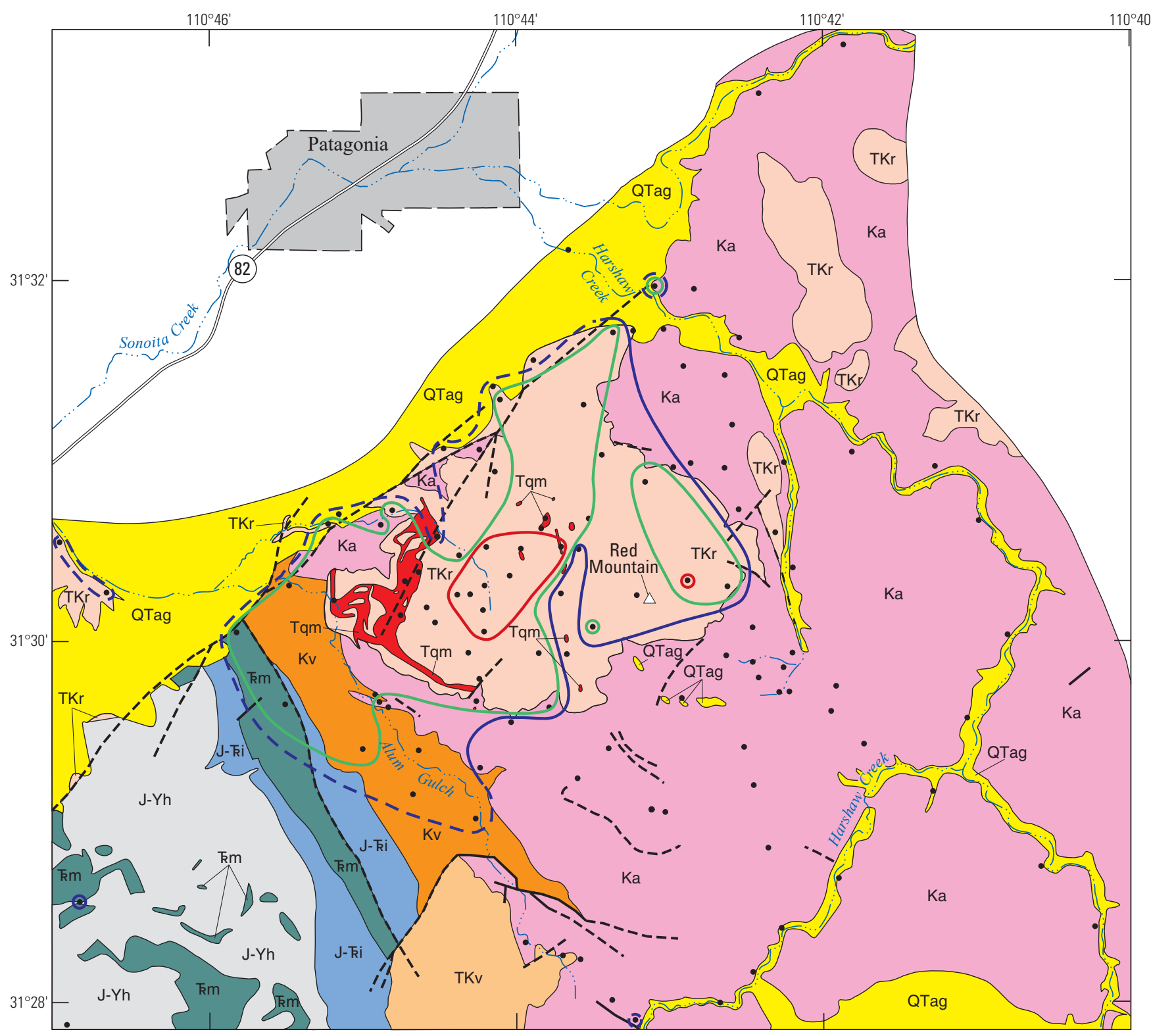

EXPLANATION

QTag Alluvium and terrace gravels, undivided

Quartz monzonite porphyryIntrusive rocks

TKr Volcanics of Red Mountain - Chiefly rhyolite tuff. Drewes, 1971a; 1972

TKv Felsic volcanic rocks-Chiefly latite

$\mathrm{Ka}$ Trachyandesite of Meadow ValleyChiefly andesite porphyry. Simons, 1972

Kv Silicic volcanics-Simons, 1974

$\mathrm{J}-\mathrm{ki}$ Plutonic and volcanic rocks, undivided

Mount Wrightson Formation-Chiefly felsic volcanics

$\mathrm{J}-\mathrm{Yh}$ Hornblende-rich metamorphic and igneous rocks, undivided Contact-Locally concealed or inferred

_ Fault-Dashed where approximate or inferred

Distribution of thallium in rock samples, in parts per million-Contours are shown with a solid line where the sample density is high. Where sample density is low, the contours are dashed

$\begin{array}{ll}\square & 4.0 \\ & 2.0 \\ & 1.0\end{array}$

- Sample site

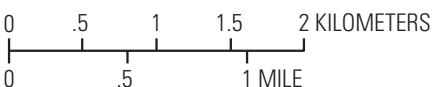

Base from U.S. Geological Survey digital data, 1:1,000,000, 2018 Geographic projection, decimal degrees North American Datum of 1927

Figure 56. Distribution of thallium in rock samples. 


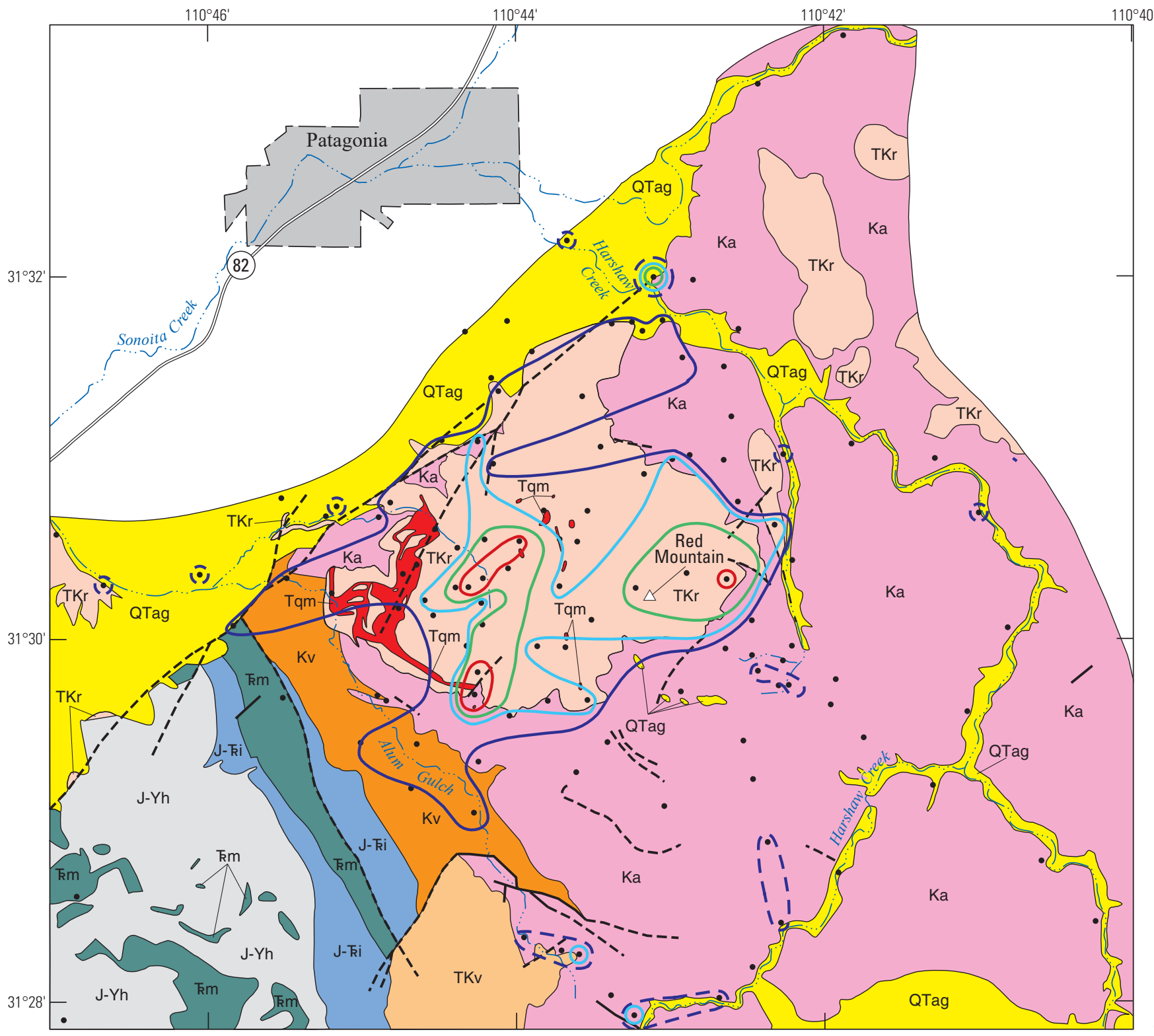

\section{EXPLANATION}

QTag Alluvium and terrace gravels, undivided

Quartz monzonite porphyryIntrusive rocks

TKr Volcanics of Red Mountain—Chiefly rhyolite tuff. Drewes, 1971a; 1972

TKv Felsic volcanic rocks-Chiefly latite

$\mathrm{Ka}$ Trachyandesite of Meadow ValleyChiefly andesite porphyry. Simons, 1972

Silicic volcanics-Simons, 1974

$\mathrm{J}-\mathrm{ki}$ Plutonic and volcanic rocks, undivided

Mount Wrightson Formation-Chiefly felsic volcanics

$\mathrm{J}-\mathrm{Yh}$ Hornblende-rich metamorphic and igneous rocks, undivided Contact-Locally concealed or inferred

Fault-Dashed where approximate or inferred

Distribution of thallium in soil samples, in parts per million-Contours are shown with a solid line where the sample density is high. Where sample density is low, the contours are dashed

6.0
$-\quad 3.0$
3.0

$\longrightarrow \quad 3.0$

- Sample site

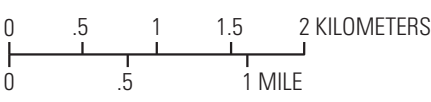

Base from U.S. Geological Survey digital data, 1:1,000,000, 2018 Geographic projection, decimal degrees

North American Datum of 1927

Geology modified from Drewes (1971a), Quinlan (1981, 1986) and Simons (1974).

Figure 57. Distribution of thallium in soil samples. 


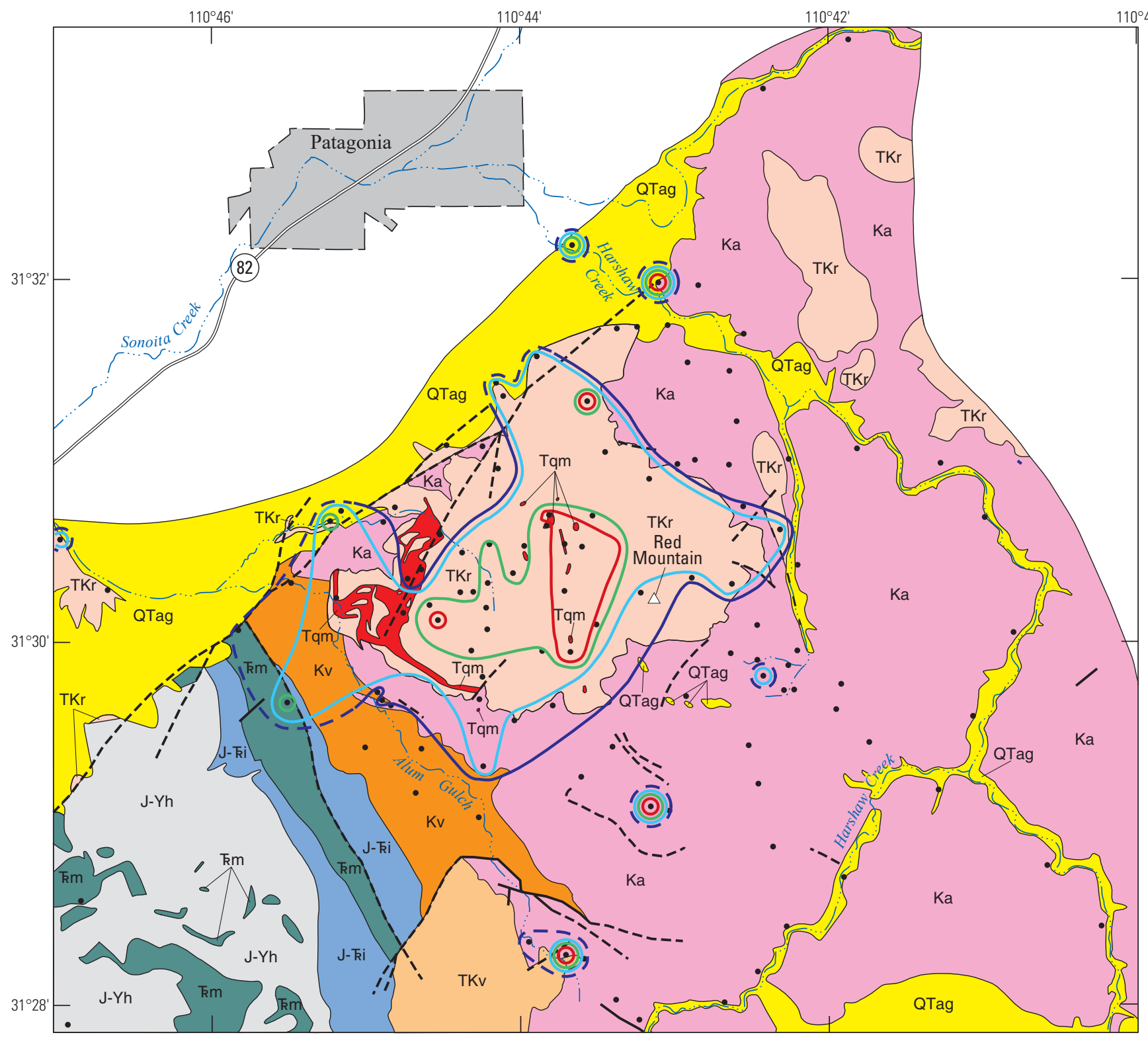

EXPLANATION

QTag Alluvium and terrace gravels, undivided

Quartz monzonite porphyryIntrusive rocks

TKr Volcanics of Red Mountain - Chiefly rhyolite tuff. Drewes, 1971a; 1972

TKv Felsic volcanic rocks-Chiefly latite

$\mathrm{Ka}$ Trachyandesite of Meadow ValleyChiefly andesite porphyry. Simons, 1972

Kv Silicic volcanics-Simons, 1974

$\mathrm{J}-\mathrm{ki}$ Plutonic and volcanic rocks, undivided

Mount Wrightson Formation-Chiefly felsic volcanics

$\mathrm{J}$-Yh Hornblende-rich metamorphic and igneous rocks, undivided Contact-Locally concealed or inferred

ault-Dashed where approximate or inferred

Distribution of lead in rock samples, in parts per million-Contours are shown with a solid line where the sample density is high. Where sample density is low, the contours are dashed

$\begin{array}{r}500 \\ -\quad 300 \\ \hline\end{array}$

$\begin{array}{ll}- & 100 \\ - & 40\end{array}$

- Sample site

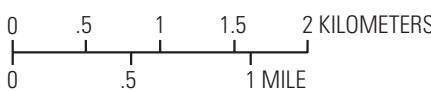

Base from U.S. Geological Survey digital data, 1:1,000,000, 2018 Geographic projection, decimal degrees North American Datum of 1927

Figure 58. Distribution of lead in rock samples. 


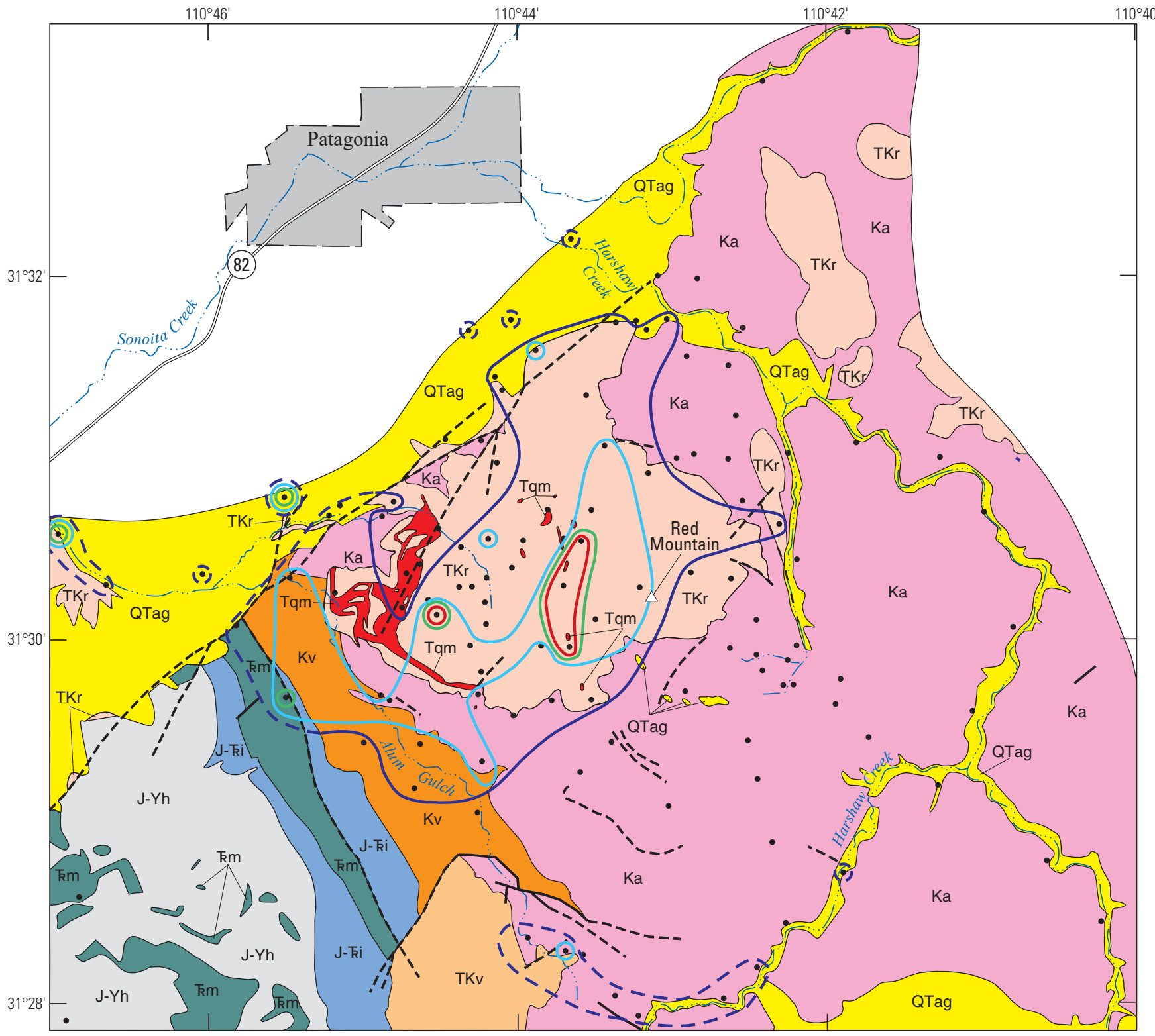

\section{EXPLANATION}

QTag Alluvium and terrace gravels, undivided

Quartz monzonite porphyryIntrusive rocks

TKr Volcanics of Red Mountain-Chiefly rhyolite tuff. Drewes, 1971a; 1972

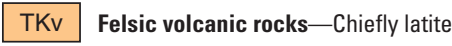

$\mathrm{Ka}$ Trachyandesite of Meadow ValleyChiefly andesite porphyry. Simons, 1972

Kv Silicic volcanics-Simons, 1974

$\mathrm{J}$ - $\mathrm{ki}$ Plutonic and volcanic rocks, undivided

Mount Wrightson Formation-Chiefly felsic volcanics

$\mathrm{J}-\mathrm{Yh}$ Hornblende-rich metamorphic and igneous rocks, undivide Contact-Locally concealed or inferred

Fault—Dashed where approximate or inferred

Distribution of lead in soil samples, in parts per million-Contours are shown with a solid line where the sample density is high. Where sample density is low, the contours are dashed

$\begin{array}{r}-\quad 800 \\ \hline\end{array} 50$

$\square 00$
$-\quad 300$

- Sample sit

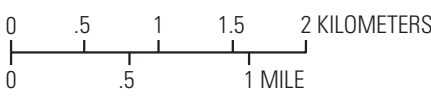

Base from U.S. Geological Survey digital data, 1:1,000,000, 2018 Geographic projection, decimal degrees

North American Datum of 1927

Geology modified from Drewes (1971a), Quinlan $(1981,1986)$ and Simons (1974).

Figure 59. Distribution of lead in soil samples. 


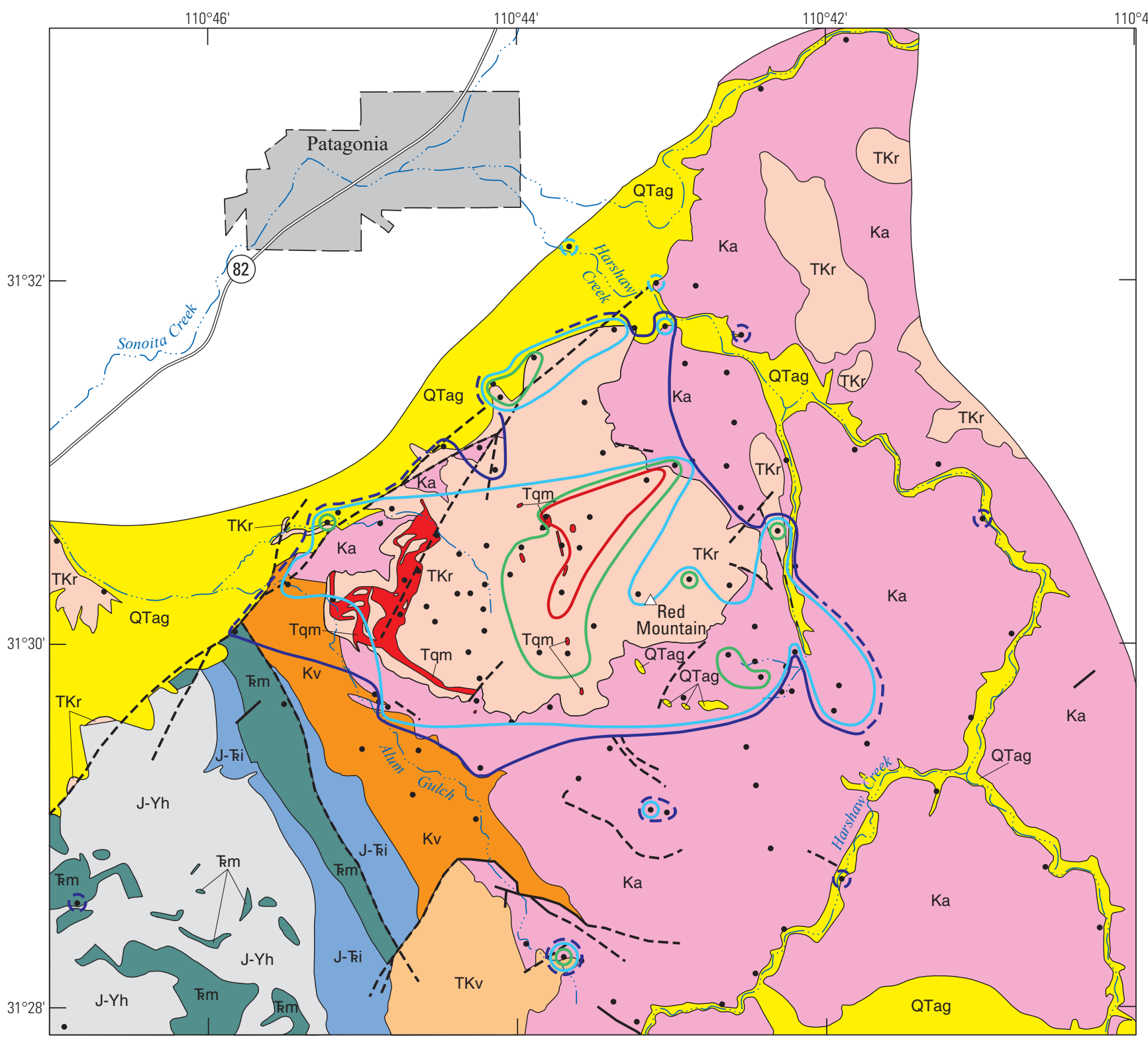

QTag Alluvium and terrace gravels, undivided

Quartz monzonite porphyryIntrusive rocks

TKr Volcanics of Red Mountain-Chiefly rhyolite tuff. Drewes, 1971a; 1972

TKv Felsic volcanic rocks-Chiefly latite

$\mathrm{Ka}$ Trachyandesite of Meadow ValleyChiefly andesite porphyry. Simons, 1972

Kv Silicic volcanics-Simons, 1974

$\mathrm{J}-\mathrm{ki}$ Plutonic and volcanic rocks, undivided

Mount Wrightson Formation-Chiefly felsic volcanics

$\mathrm{J}-\mathrm{Yh}$ Hornblende-rich metamorphic and igneous rocks, undivided Contact-Locally concealed or

inferred

— Fault-Dashed where approximate or inferred

Distribution of tellurium in rock samples, in parts per million-Contours are shown with a solid line where the sample density is high. Where sample density is low, the contours are dashed

\begin{tabular}{l}
$\square$ \\
$\square$ \\
$\square$ \\
$\square$ \\
\hline$\square$
\end{tabular} .0 .2

- Sample site

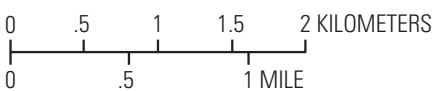

Base from U.S. Geological Survey digital data, 1:1,000,000, 2018 Geographic projection, decimal degrees North American Datum of 1927

Geology modified from Drewes (1971a), Quinlan (1981, 1986), and Simons (1974)

Figure 60. Distribution of tellurium in rock samples. 


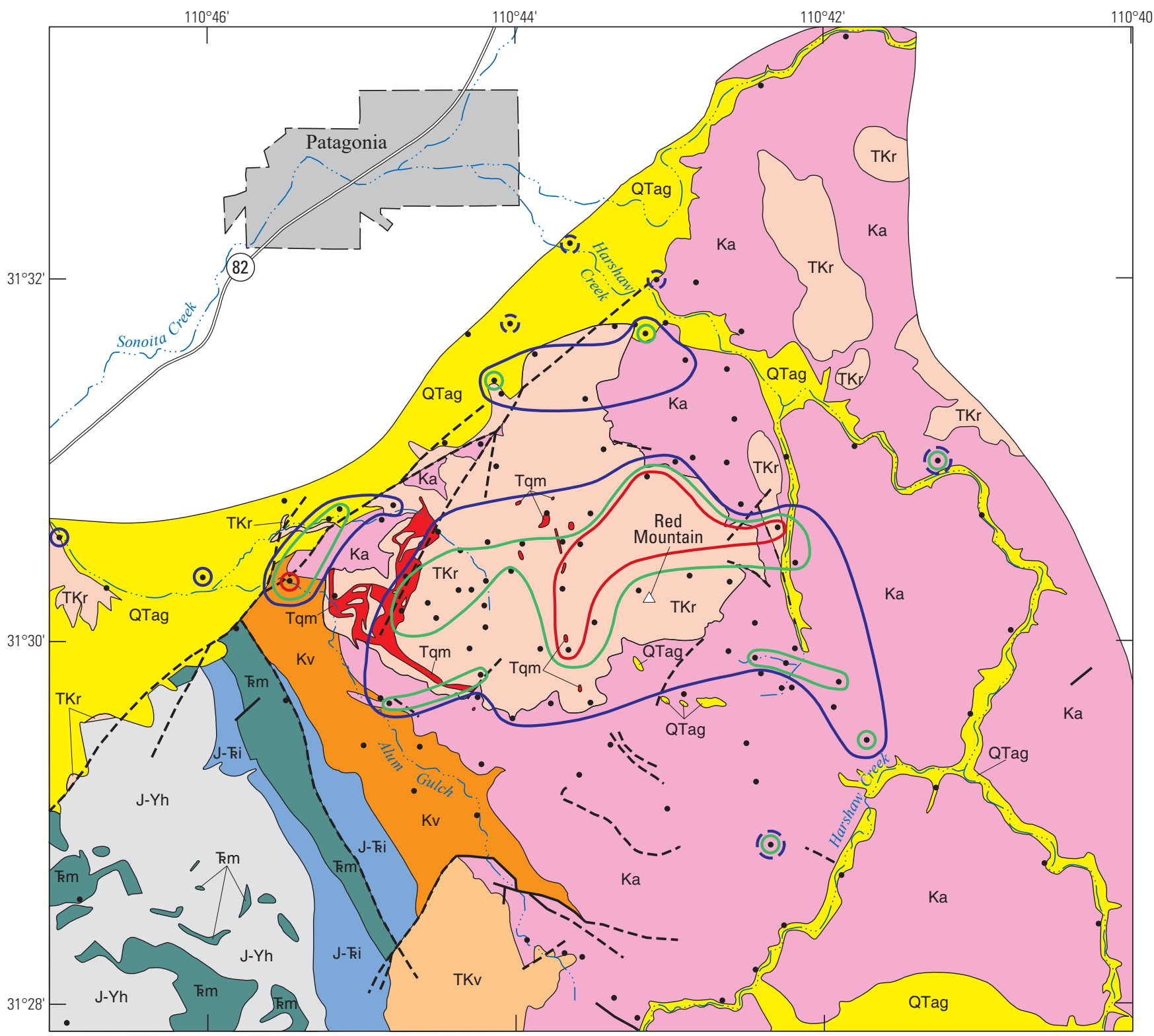

\section{EXPLANATION}

QTag Alluvium and terrace gravels, undivided

Quartz monzonite porphyryIntrusive rocks

TKr Volcanics of Red Mountain-Chiefly rhyolite tuff. Drewes, 1971a; 1972

TKv Felsic volcanic rocks-Chiefly latite

$\mathrm{Ka}$ Trachyandesite of Meadow ValleyChiefly andesite porphyry. Simons, 1972

Kv Silicic volcanics-Simons, 1974

$\mathrm{J}$ - $\mathrm{ki}$ Plutonic and volcanic rocks undivided

Mount Wrightson Formation-Chiefly felsic volcanics

$\mathrm{J}-\mathrm{Yh}$ Hornblende-rich metamorphic and igneous rocks, undivided Contact-Locally concealed or inferred

Fault-Dashed where approximate or inferred

Distribution of tellurium in soil samples, in parts per million-Contours are shown parts per million-Contours are show
with a solid line where the sample density is high. Where sample density is low, the contours are dashed

$\begin{array}{r}-2.0 \\ \hline \\ \hline\end{array}$ low, the contours

- Sample sit

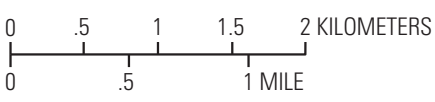

Base from U.S. Geological Survey digital data, 1:1,000,000, 2018 Geographic projection, decimal degrees

North American Datum of 1927

Geology modified from Drewes (1971a), Quinlan (1981, 1986) and Simons (1974).

Figure 61. Distribution of tellurium in soil samples. 


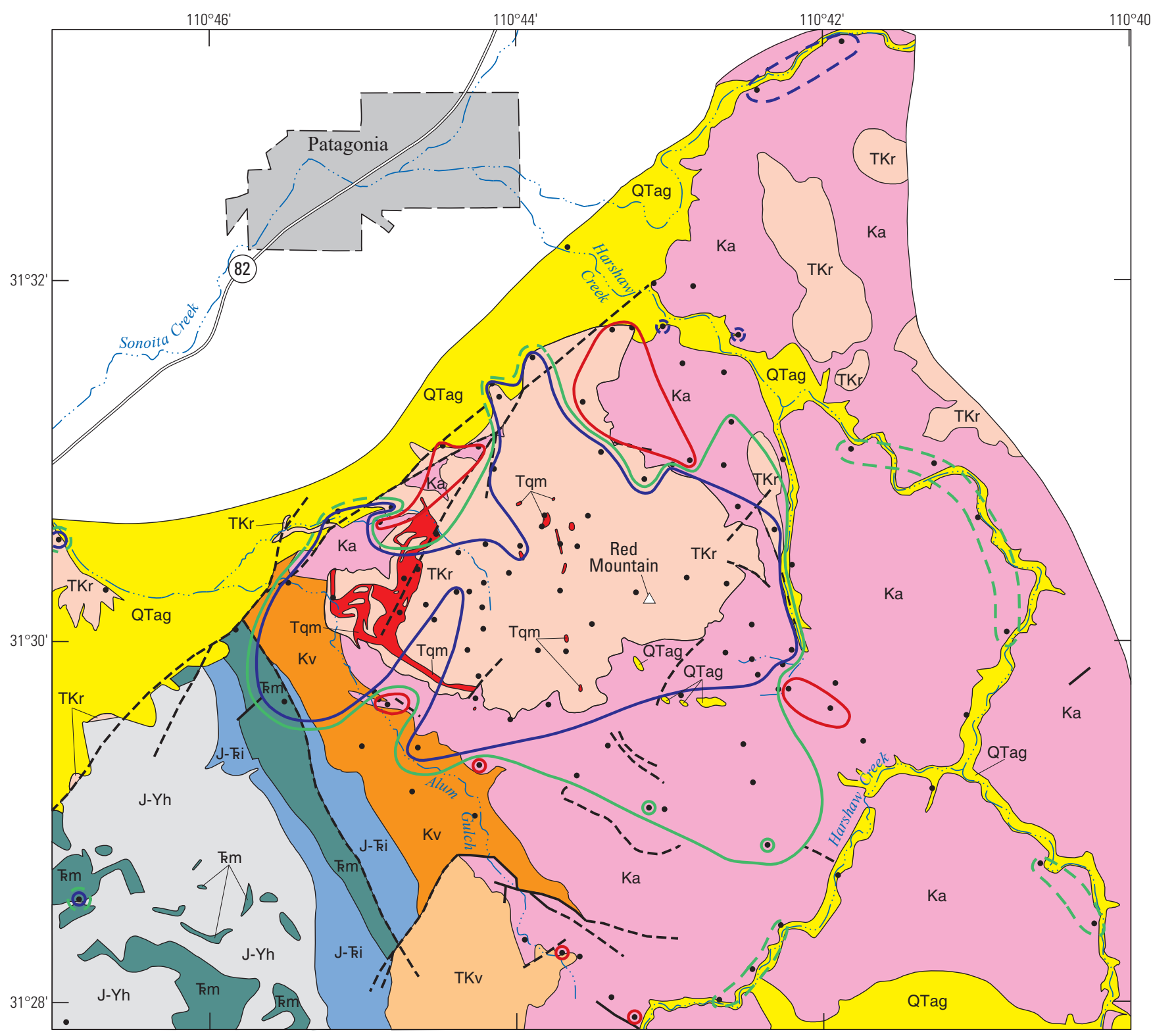

EXPLANATION

QTag Alluvium and terrace gravels, undivided

Quartz monzonite porphyryIntrusive rocks

TKr Volcanics of Red Mountain - Chiefly rhyolite tuff. Drewes, 1971a; 1972

TKv Felsic volcanic rocks-Chiefly latite

Ka Trachyandesite of Meadow ValleyChiefly andesite porphyry. Simons, 1972

Kv Silicic volcanics-Simons, 1974

$\mathrm{J}-\mathrm{ki}$ Plutonic and volcanic rocks, undivided

Mount Wrightson Formation-Chiefly felsic volcanics

$\mathrm{J}-\mathrm{Yh}$ Hornblende-rich metamorphic and igneous rocks, undivided Contact-Locally concealed or inferred

Fault-Dashed where approximate or inferred

Distribution of zinc in rock samples, in parts per million-Contours are shown with a solid line where the sample density is high. Where sample density is low, the contours are dashed

\begin{tabular}{ll}
$\square$ & 200 \\
\hline & 100
\end{tabular}

- Sample site

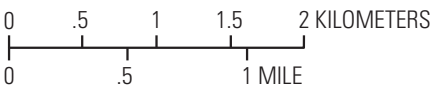

Base from U.S. Geological Survey digital data, 1:1,000,000, 2018 Geographic projection, decimal degrees North American Datum of 1927

Figure 62. Distribution of zinc in rock samples. 


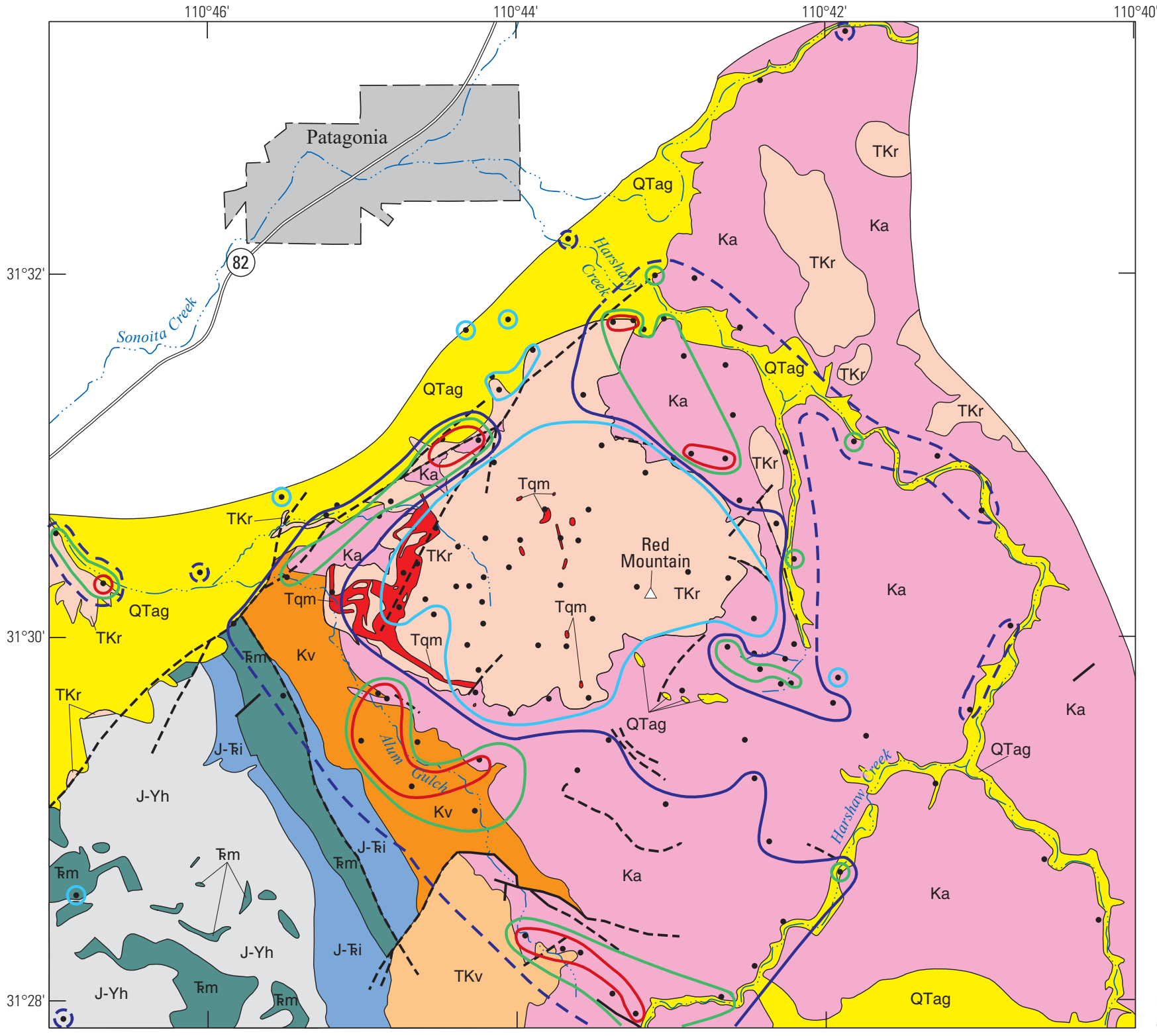

Figure 63. Distribution of zinc in soil samples.

\section{EXPLANATION}

QTag Alluvium and terrace gravels, undivided

Quartz monzonite porphyryIntrusive rocks

TKr Volcanics of Red Mountain-Chiefly rhyolite tuff. Drewes, 1971a; 1972

TKv Felsic volcanic rocks-Chiefly latite

$\mathrm{Ka}$ Trachyandesite of Meadow ValleyChiefly andesite porphyry. Simons, 1972

Kv Silicic volcanics-Simons, 1974

$\mathrm{J}-\mathrm{ki}$ Plutonic and volcanic rocks, undivided

Mount Wrightson Formation-Chiefly felsic volcanics

$\mathrm{J}-\mathrm{Yh}$ Hornblende-rich metamorphic and igneous rocks, undivide Contact-Locally concealed or inferred

Fault—Dashed where approximate or inferred

Distribution of zinc in soil samples, in parts per million-Contours are shown with a solid line where the sample density is high. Where sample density is low, the contour

$-\quad 400$

-
$\square$

- $\quad$ Sample site

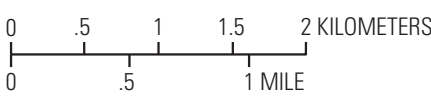

Base from U.S. Geological Survey digital data, 1:1,000,000, 2018 Geographic projection, decimal degrees

North American Datum of 1927

Geology modified from Drewes (1971a), Quinlan $(1981,1986)$ and Simons (1974). 


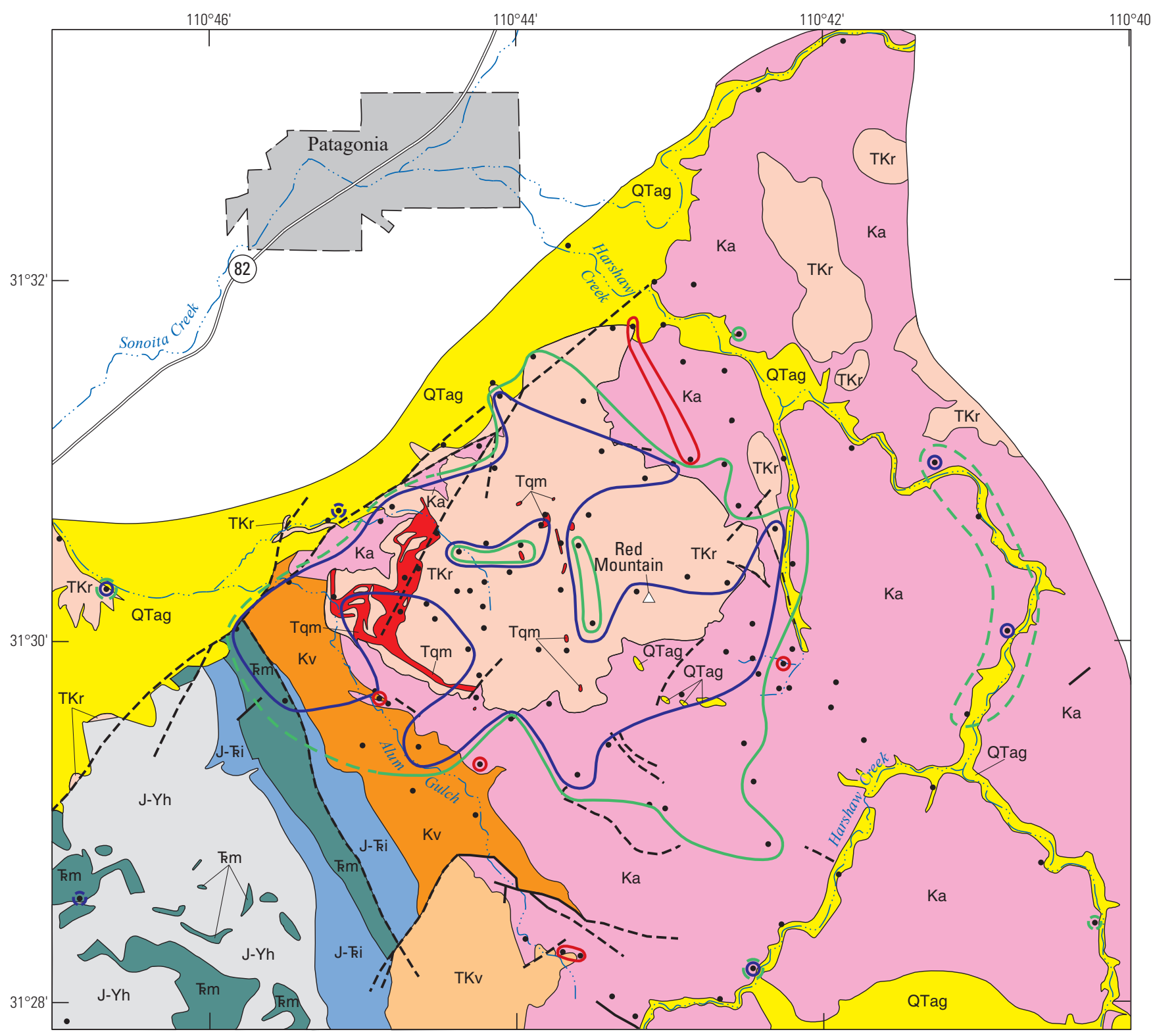

EXPLANATION

QTag Alluvium and terrace gravels, undivided

Quartz monzonite porphyryIntrusive rocks

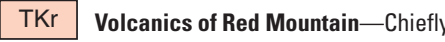
rhyolite tuff. Drewes, 1971a; 1972

TKv Felsic volcanic rocks-Chiefly latite

$\mathrm{Ka}$ Trachyandesite of Meadow ValleyChiefly andesite porphyry. Simons, 1972

Kv Silicic volcanics—Simons, 1974

$\mathrm{J}-\mathrm{ki}$ Plutonic and volcanic rocks, undivided

Mount Wrightson Formation-Chiefly felsic volcanics

$\mathrm{J}-\mathrm{Yh}$ Hornblende-rich metamorphic and igneous rocks, undivided Contact-Locally concealed or inferred

_ Fault-Dashed where approximate or inferred

Distribution of cadmium in rock samples, in parts per million-Contours are shown with a solid line where the sample density is high. Where sample density is low, the contours are dashed

0.50
$-\quad 0.10$
0.05

- Sample site

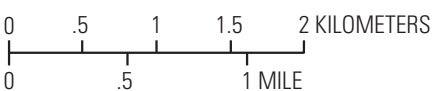

Base from U.S. Geological Survey digital data, 1:1,000,000, 2018 Geographic projection, decimal degrees North American Datum of 1927

Figure 64. Distribution of cadmium in rock samples. 


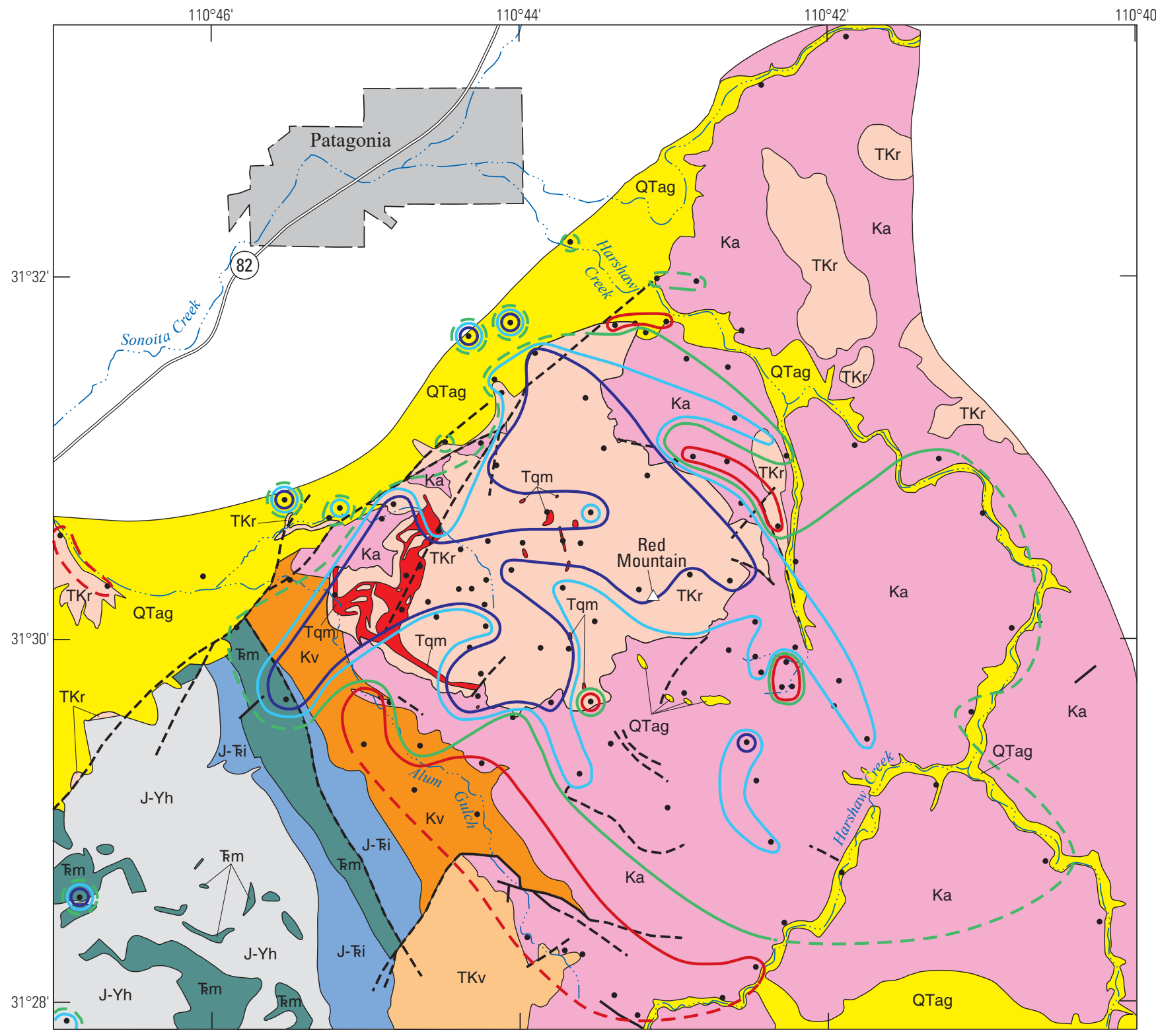

\section{EXPLANATION}

QTag Alluvium and terrace gravels, undivided

Quartz monzonite porphyryIntrusive rocks

TKr Volcanics of Red Mountain-Chiefly rhyolite tuff. Drewes, 1971a; 1972

TKv Felsic volcanic rocks-Chiefly latite

$\mathrm{Ka}$ Trachyandesite of Meadow ValleyChiefly andesite porphyry. Simons, 1972

Kv Silicic volcanics-Simons, 1974

$\mathrm{J}-\mathrm{ki}$ Plutonic and volcanic rocks, undivided

Mount Wrightson Formation-Chiefly felsic volcanics

$\mathrm{J}-\mathrm{Yh}$ Hornblende-rich metamorphic and igneous rocks, undivided Contact-Locally concealed or inferred Fault-Dashed where approximate
or inferred

Distribution of cadmium in soil samples, in parts per million-Contours are show with a solid line where the sample density is high. Where sample density is low, the contours are dashed

0.70
0.50

$\longrightarrow \begin{array}{r}0.50 \\ 0.25 \\ 0.20\end{array}$

- Sample sit

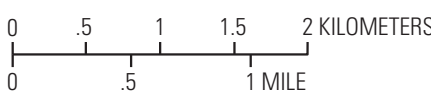

Base from U.S. Geological Survey digital data, 1:1,000,000, 2018 Geographic projection, decimal degrees

North American Datum of 1927

Geology modified from Drewes (1971a), Quinlan (1981, 1986) and Simons (1974).

Figure 65. Distribution of cadmium in soil samples. 


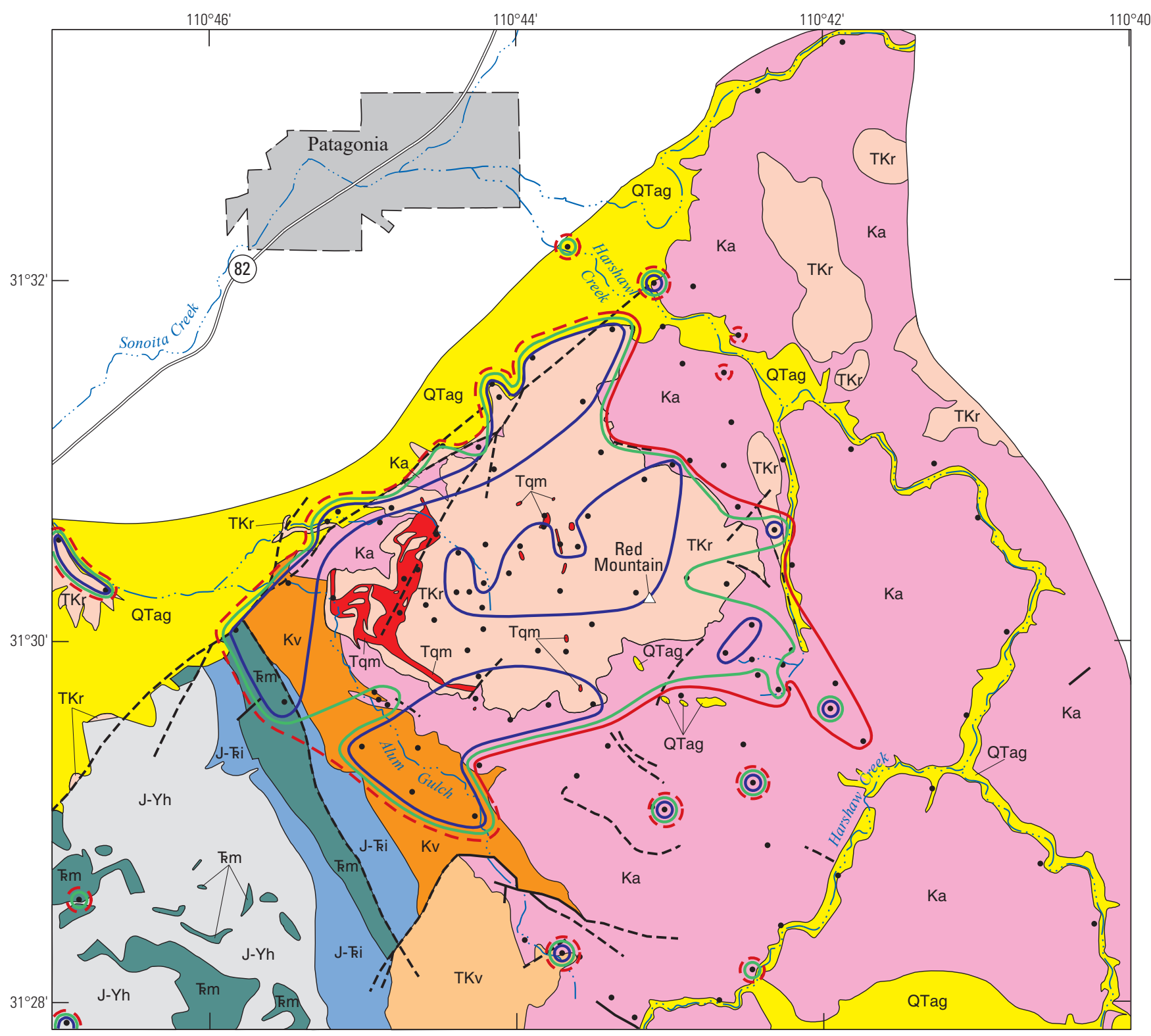

\section{EXPLANATION}

QTag Alluvium and terrace gravels, undivided

Quartz monzonite porphyryIntrusive rocks

TKr Volcanics of Red Mountain-Chiefly rhyolite tuff. Drewes, 1971a; 1972

TKv Felsic volcanic rocks-Chiefly latite

Ka Trachyandesite of Meadow ValleyChiefly andesite porphyry.

$$
\text { Simons, } 1972
$$

Kv Silicic volcanics-Simons, 1974

$\mathrm{J}-\mathrm{ki}$ Plutonic and volcanic rocks, undivided

Mount Wrightson Formation-Chiefly felsic volcanics

$\mathrm{J}-\mathrm{Yh}$ Hornblende-rich metamorphic and igneous rocks, undivided Contact-Locally concealed or inferred

Fault-Dashed where approximate or inferred

Distribution of cobalt in rock samples, in parts per million-Contours are shown with a solid line where the sample density is high. Where sample density is low, the contours are dashed

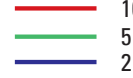

- Sample sit

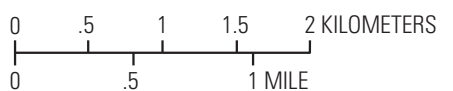

Base from U S. Geological Survey digital data, 1:1,000,000, 2018 Geographic projection, decimal degrees North American Datum of 1927

Figure 66. Distribution of cobalt in rock samples. 


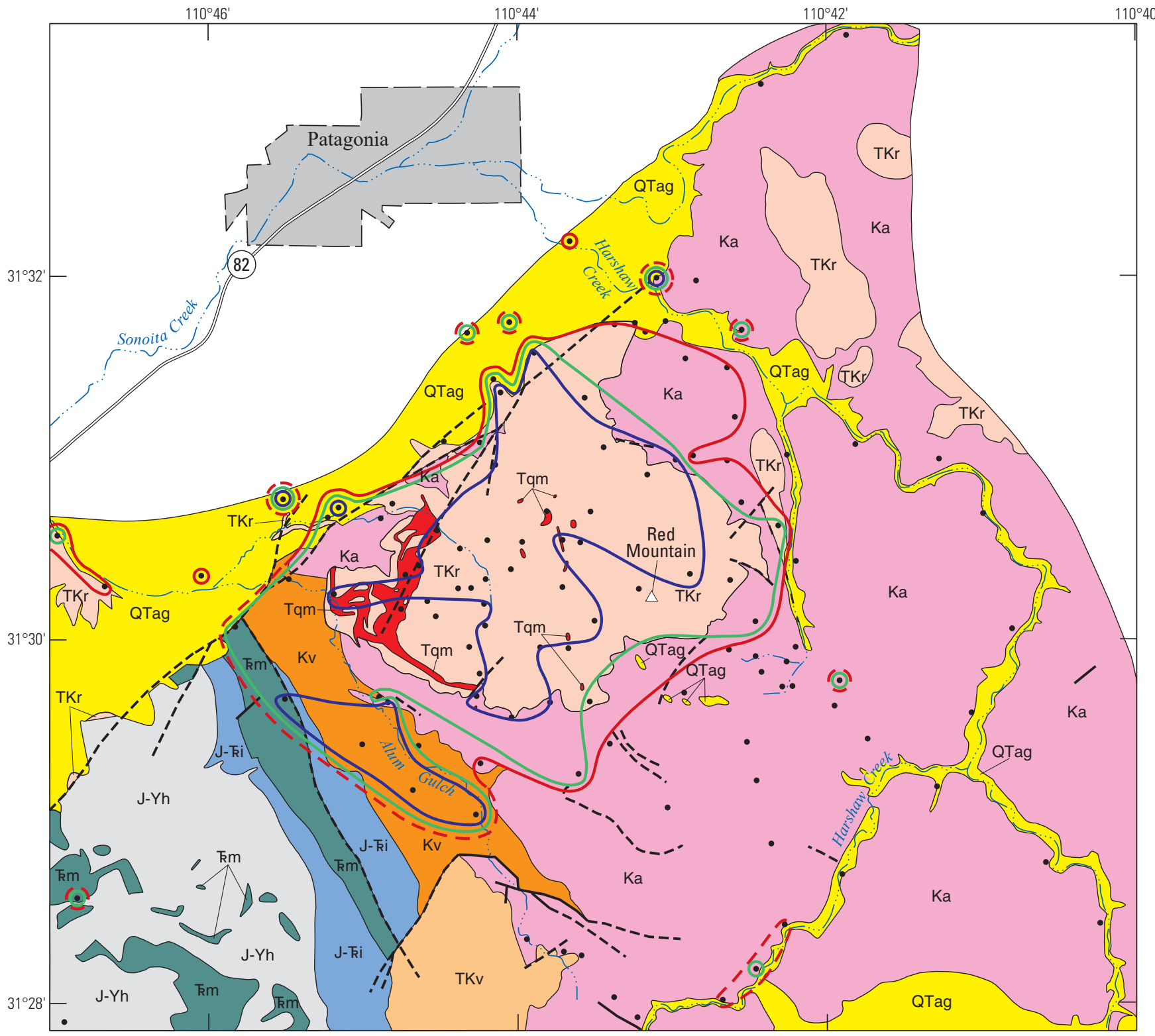

\section{EXPLANATION}

QTag Alluvium and terrace gravels, undivided

Quartz monzonite porphyryIntrusive rocks

TKr Volcanics of Red Mountain-Chiefly rhyolite tuff. Drewes, 1971a; 1972

TKv Felsic volcanic rocks-Chiefly latite

Ka Trachyandesite of Meadow ValleyChiefly andesite porphyry. Simons, 1972

Kv Silicic volcanics-Simons, 1974

$\mathrm{J}-\mathrm{Ki}$ Plutonic and volcanic rocks undivided

Mount Wrightson Formation-Chiefly felsic volcanics

$\mathrm{J}-\mathrm{Yh}$ Hornblende-rich metamorphic and igneous rocks, undivide Contact-Locally concealed or inferred

Fault-Dashed where approximate or inferred

Distribution of cobalt in soil samples, in parts per million-Contours are shown with a solid line where the sample density is high. Where sample density is low, the contours are dashed

$\longrightarrow \quad 10$

- Sample sit

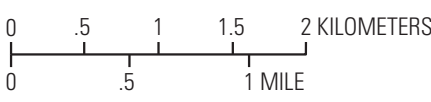

Base from U.S. Geological Survey digital data, 1:1,000,000, 2018 Geographic projection, decimal degrees North American Datum of 1927

Geology modified from Drewes (1971a), Quinlan $(1981,1986)$ and Simons (1974).

Figure 67. Distribution of cobalt in soil samples. 


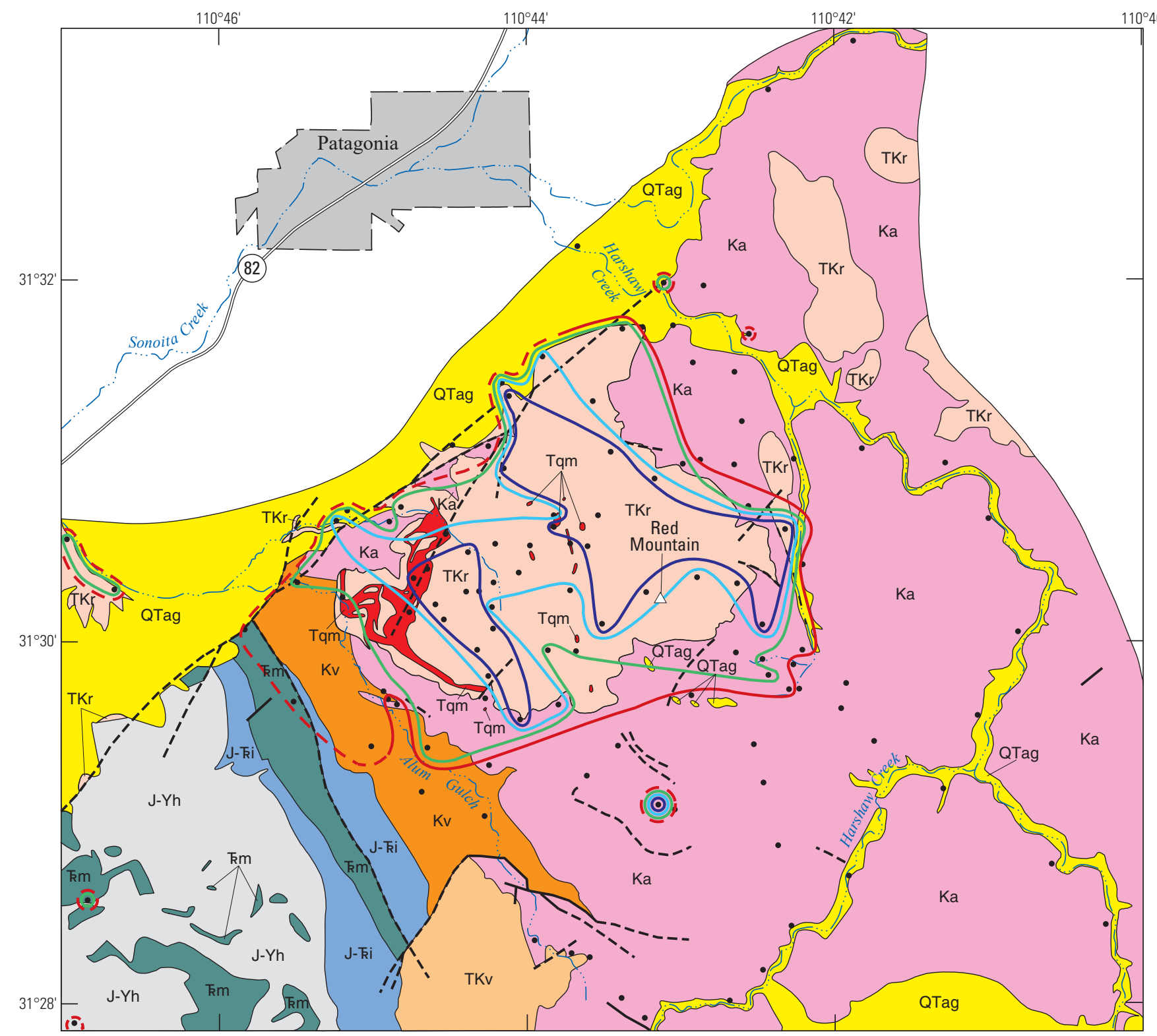

\section{EXPLANATION}

QTag Alluvium and terrace gravels, undivided

Quartz monzonite porphyryIntrusive rocks

TKr Volcanics of Red Mountain - Chiefly rhyolite tuff. Drewes, 1971a; 1972

TKv Felsic volcanic rocks-Chiefly latite

Ka Trachyandesite of Meadow ValleyChiefly andesite porphyry. Simons, 1972

Kv Silicic volcanics-Simons, 1974

J-ki Plutonic and volcanic rocks, undivided

Mount Wrightson Formation-Chiefly felsic volcanics

$\mathrm{J}$-Yh Hornblende-rich metamorphic and

$$
\text { igneous rocks, undivided }
$$

inferred
Fault-Dashed where approximate or inferred

Distribution of manganese in rock samples, in parts per million-Contours are shown with a solid line where the sample density is high. Where sample density is low, the contours are dashed

5

- $\quad$ Sample site

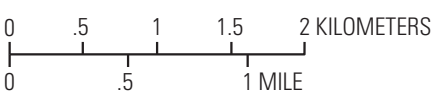

Base from U.S. Geological Survey digital data, 1:1,000,000, 2018 Geographic projection, decimal degrees North American Datum of 1927

Figure 68. Distribution of manganese in rock samples. 


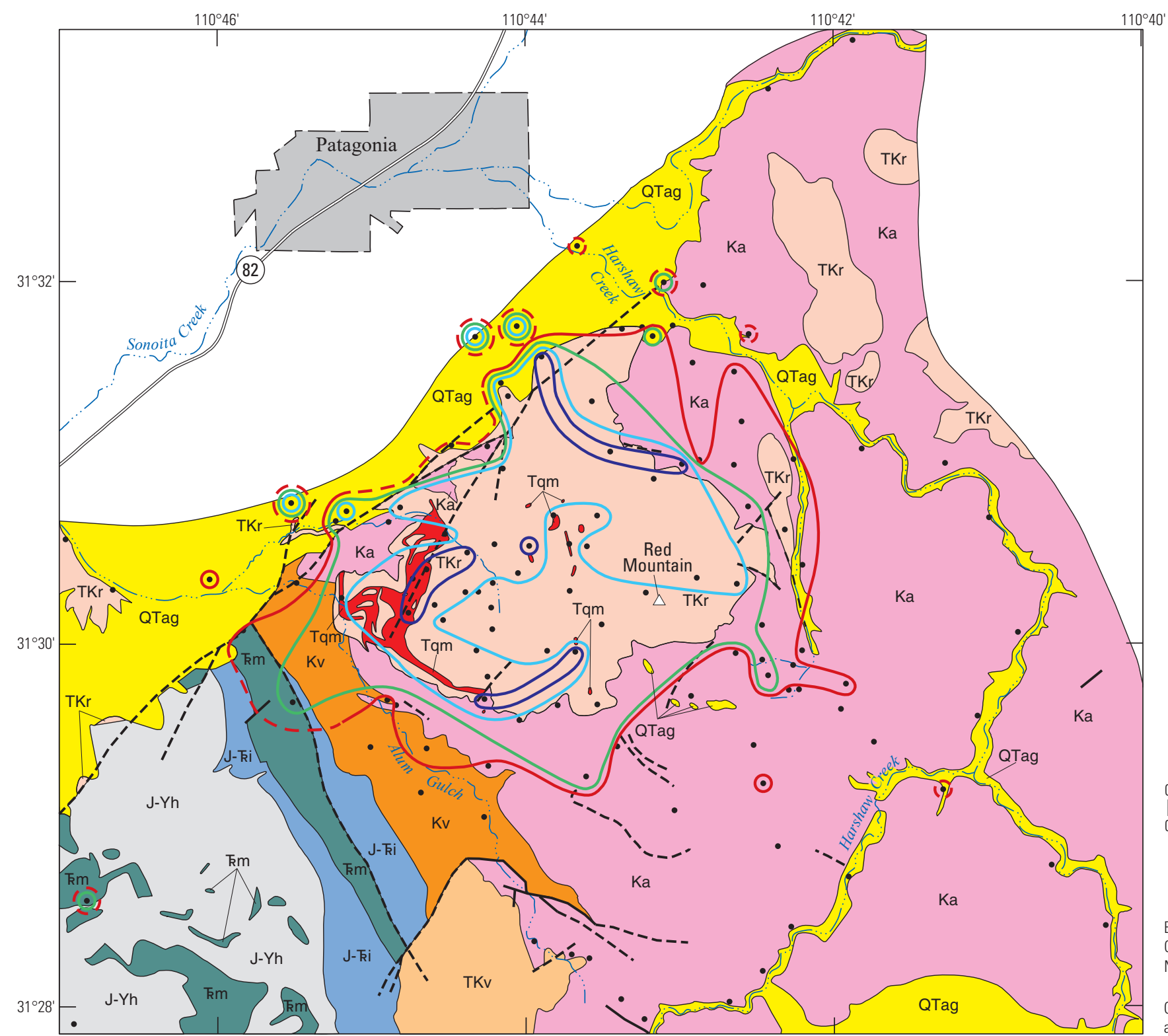

Figure 69. Distribution of manganese in soil samples.

\section{EXPLANATION}

QTag Alluvium and terrace gravels, undivided

Quartz monzonite porphyryIntrusive rocks

TKr Volcanics of Red Mountain-Chiefly rhyolite tuff. Drewes, 1971a; 1972

TKv Felsic volcanic rocks-Chiefly latite

Ka Trachyandesite of Meadow ValleyChiefly andesite porphyry. Simons, 1972

Kv Silicic volcanics-Simons, 1974

$\mathrm{J}$ - $\mathrm{ki}$ Plutonic and volcanic rocks, undivided

Mount Wrightson Formation-Chiefly felsic volcanics

$\mathrm{J}-\mathrm{Yh}$ Hornblende-rich metamorphic and igneous rocks, undivided Contact-Locally concealed or inferred

Fault-Dashed where approximate or inferred

Distribution of manganese in soil samples,

in parts per million-Contours are

in parts per million-Contours are
shown with a solid line where the sample density is high. Where sample density is low, the contours are dashed

- 1,000

500
$-\quad 200$
100

- Sample site

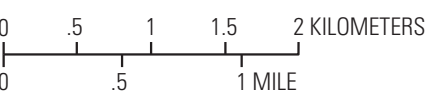

Base from U.S. Geological Survey digital data, 1:1,000,000, 2018 Geographic projection, decimal degrees

North American Datum of 1927

Geology modified from Drewes (1971a), Quinlan (1981, 1986) and Simons (1974). 


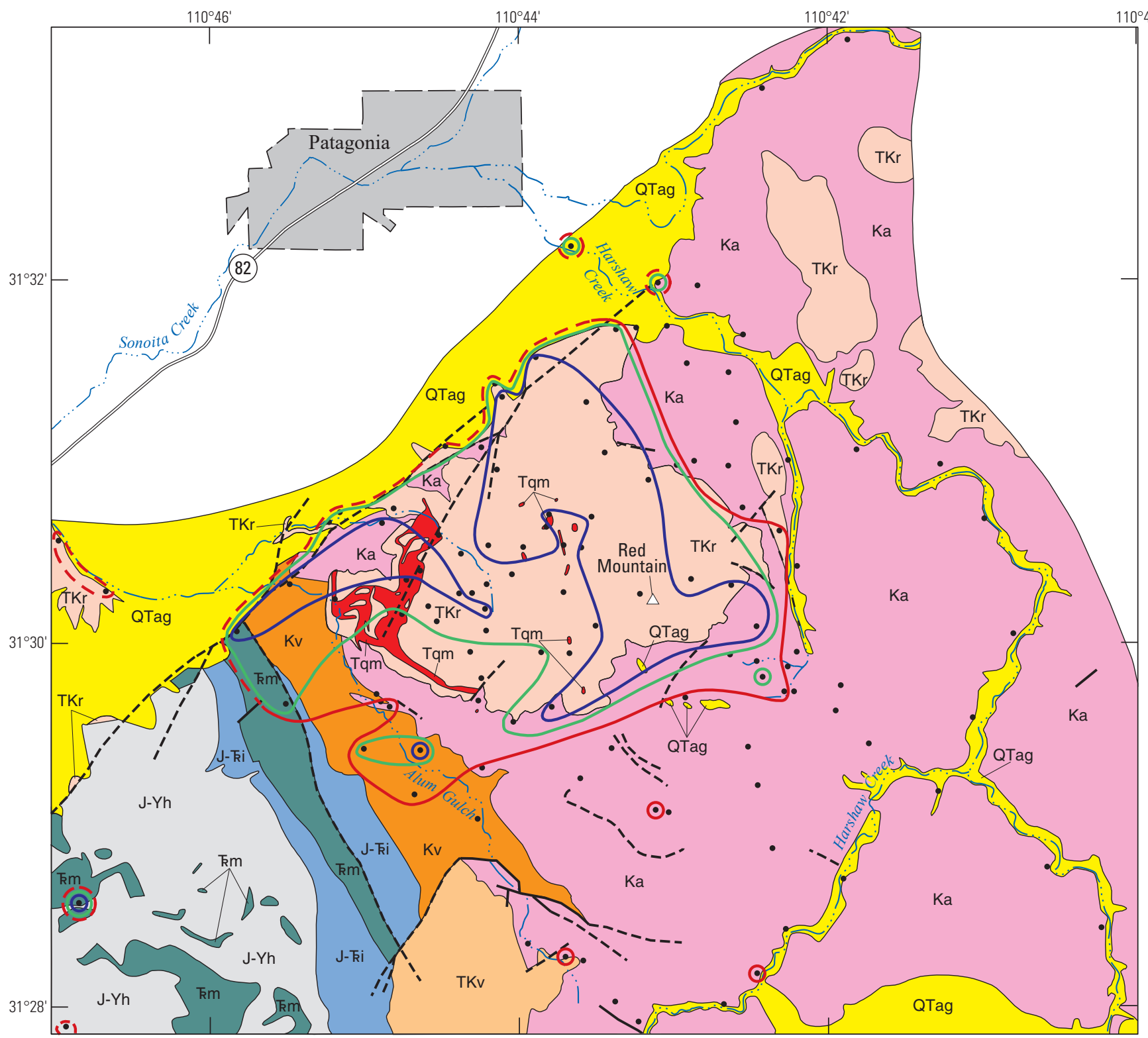

\section{EXPLANATION}

QTag Alluvium and terrace gravels, undivided

Ouartz monzonite porphyryIntrusive rocks

TKr Volcanics of Red Mountain-Chiefly rhyolite tuff. Drewes, 1971a; 1972

TKv Felsic volcanic rocks-Chiefly latite

$\mathrm{Ka}$ Trachyandesite of Meadow ValleyChiefly andesite porphyry.

$$
\text { Simons, } 1972
$$

Kv Silicic volcanics-Simons, 1974

$\mathrm{J}-\mathrm{ki}$ Plutonic and volcanic rocks, undivided

Mount Wrightson Formation-Chiefly felsic volcanics

$\mathrm{J}-\mathrm{Yh}$ Hornblende-rich metamorphic and

$$
\text { igneous rocks, undivided }
$$

Contact-Locally concealed or inferred

_ Fault-Dashed where approximate or inferred

Distribution of calcium in rock samples, in percent-Contours are shown with a solid line where the sample density is high. Where sample density is low, the contours are dashed

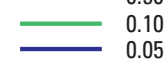

- Sample site

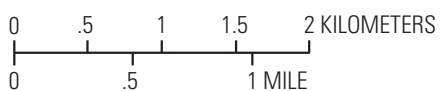

Base from U.S. Geological Survey digital data, 1:1,000,000, 2018 Geographic projection, decimal degrees North American Datum of 1927 and Simons (1974).

Figure 70. Distribution of calcium in rock samples. 


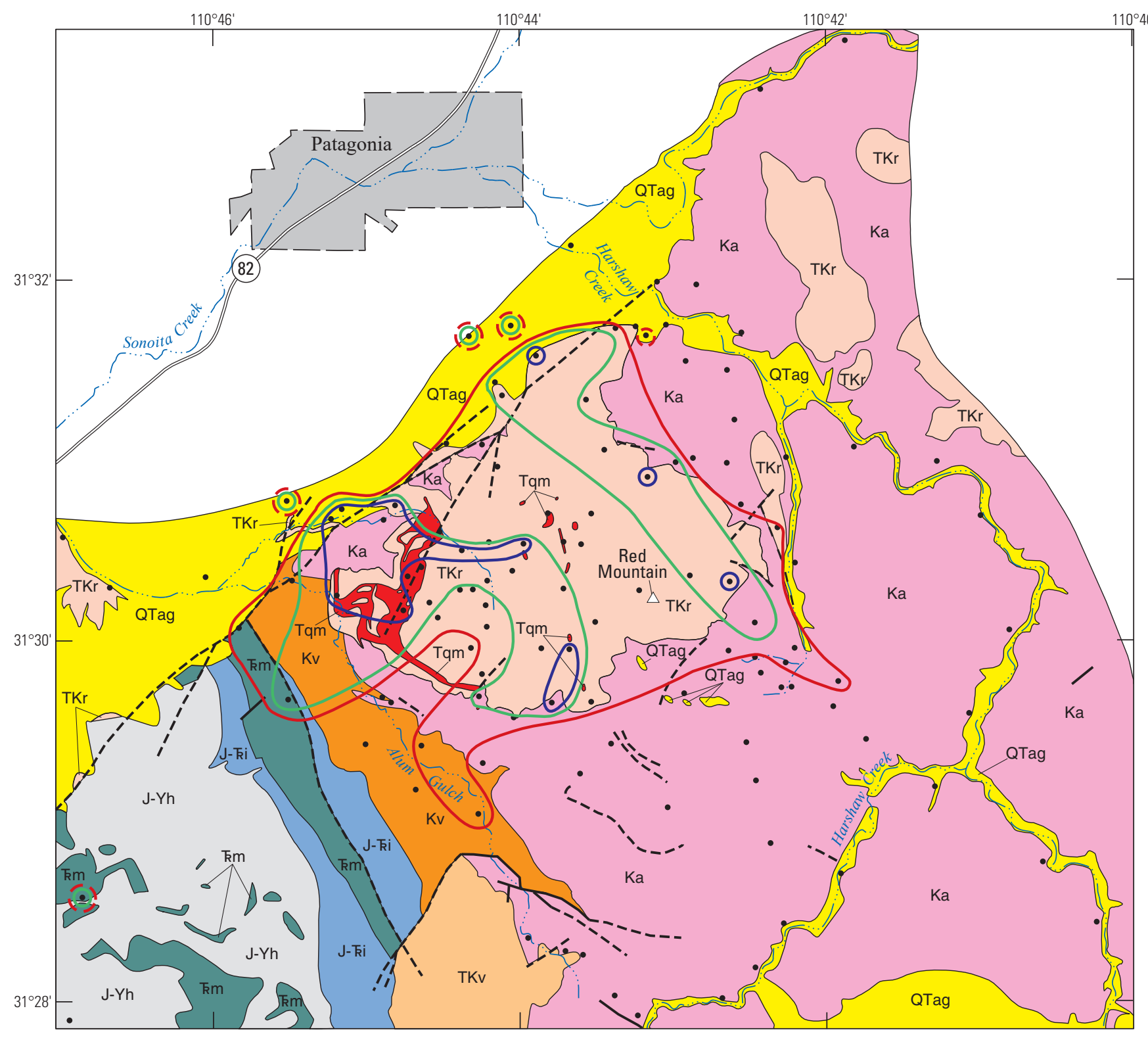

Figure 71. Distribution of calcium in soil samples.

\section{EXPLANATION}

QTag Alluvium and terrace gravels, undivided

Quartz monzonite porphyryIntrusive rocks

TKr Volcanics of Red Mountain-Chiefly rhyolite tuff. Drewes, 1971a; 1972

TKv Felsic volcanic rocks-Chiefly latite

$\mathrm{Ka}$ Trachyandesite of Meadow ValleyChiefly andesite porphyry. Simons, 1972

Kv Silicic volcanics-Simons, 1974

$\mathrm{J}-\mathrm{ki}$ Plutonic and volcanic rocks, undivided

Mount Wrightson Formation-Chiefly felsic volcanics

$\mathrm{J}-\mathrm{Yh}$ Hornblende-rich metamorphic and igneous rocks, undivided Contact-Locally concealed inferred

— Fault—Dashed where approximate$$
\text { or inferred }
$$

Distribution of calcium in soil samples, in percent-Contours are shown with a solid line where the sample density is high. Where sample density is low, th contours are dashe

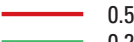

$=0.15$

- Sample site

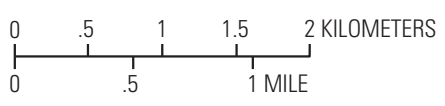

Base from U.S. Geological Survey digital data, 1:1,000,000, 2018 Geographic projection, decimal degrees

North American Datum of 1927

Geology modified from Drewes (1971a), Quinlan (1981, 1986), and Simons (1974). 


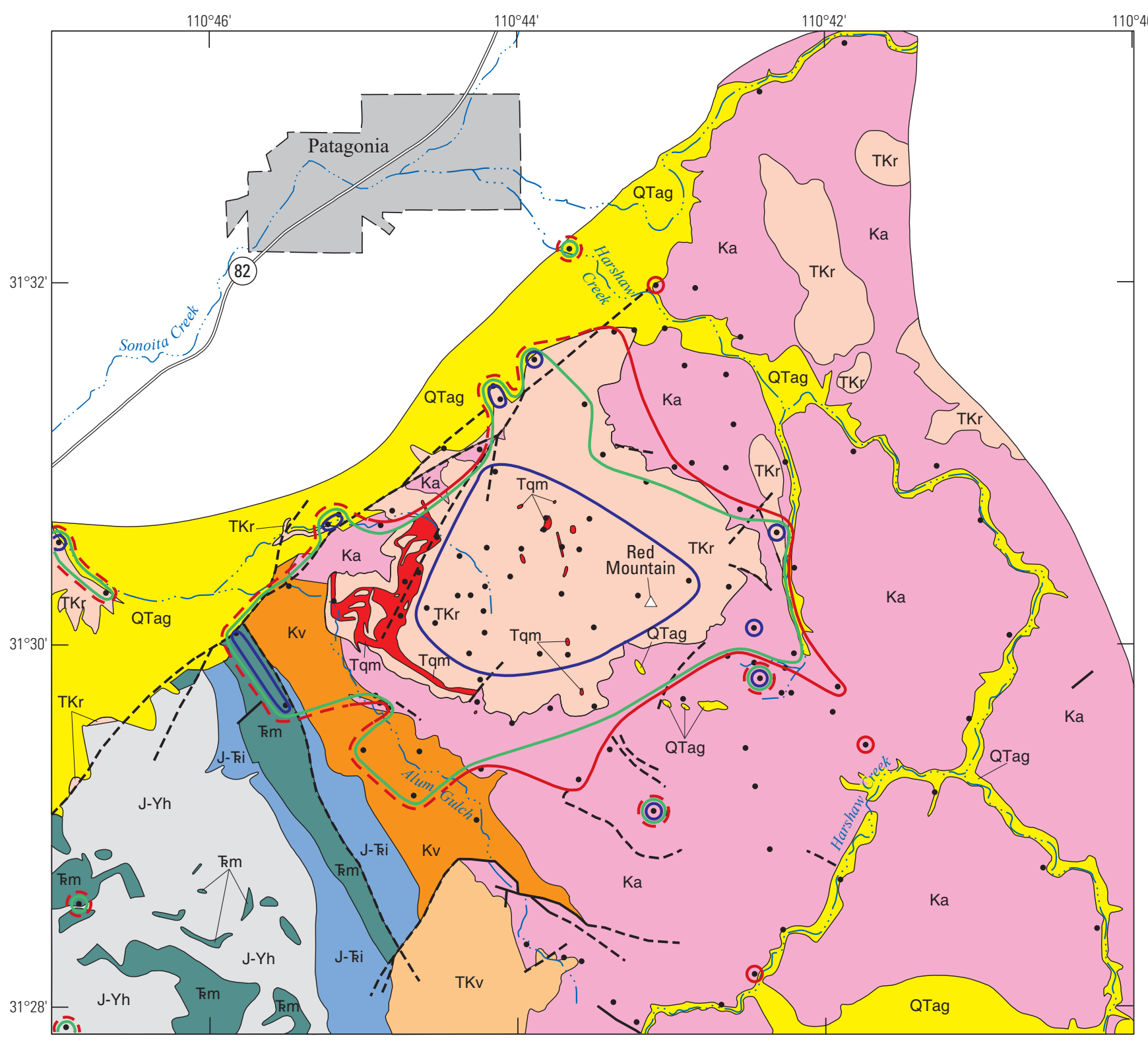

\section{EXPLANATION}

QTag Alluvium and terrace gravels undivided

Quartz monzonite porphyryIntrusive rocks

TKr Volcanics of Red Mountain-Chiefly rhyolite tuff. Drewes, 1971a; 1972

TKv Felsic volcanic rocks-Chiefly latite

Ka Trachyandesite of Meadow ValleyChiefly andesite porphyry. Simons, 1972

Kv Silicic volcanics-Simons, 1974

$\mathrm{J}-\mathrm{ki}$ Plutonic and volcanic rocks. undivided

Mount Wrightson Formation-Chiefly felsic volcanics

$\mathrm{J}-\mathrm{Yh}$ Hornblende-rich metamorphic and

$$
\text { igneous rocks, undivided }
$$

inferred

- Fault-Dashed where approximate or inferred

Distribution of magnesium in rock samples, in percent-Contours are shown with a solid line where the sample density is high. Where sample density is low, the contours are dashed

$\longrightarrow \begin{array}{r}0.50 \\ 0.30 \\ 0.10\end{array}$

- Sample site

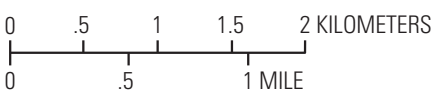

Base from U.S. Geological Survey digital data, 1:1,000,000, 2018 Geographic projection, decimal degrees North American Datum of 1927

Figure 72. Distribution of magnesium in rock samples. 

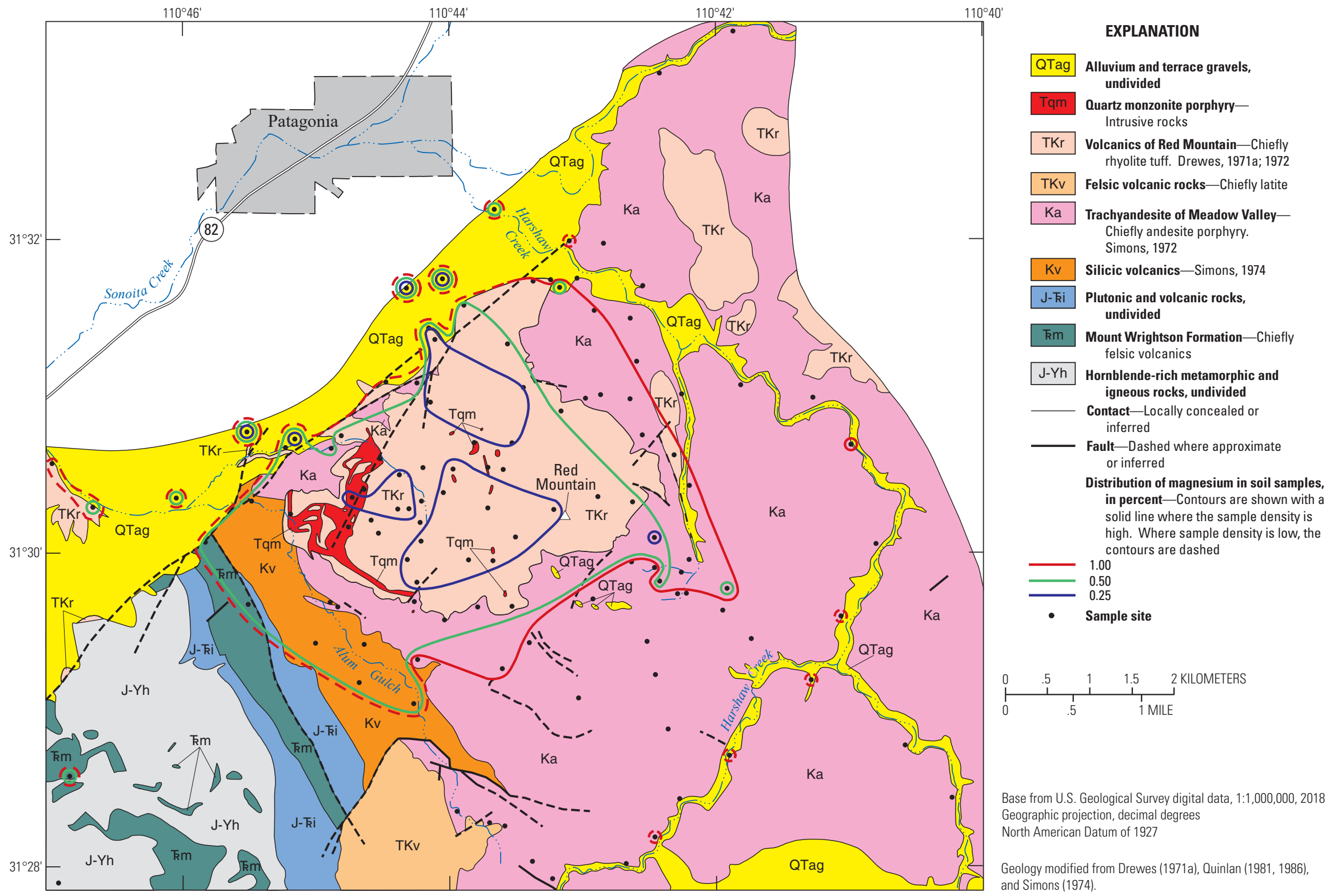

Figure 73. Distribution of magnesium in soil samples. 


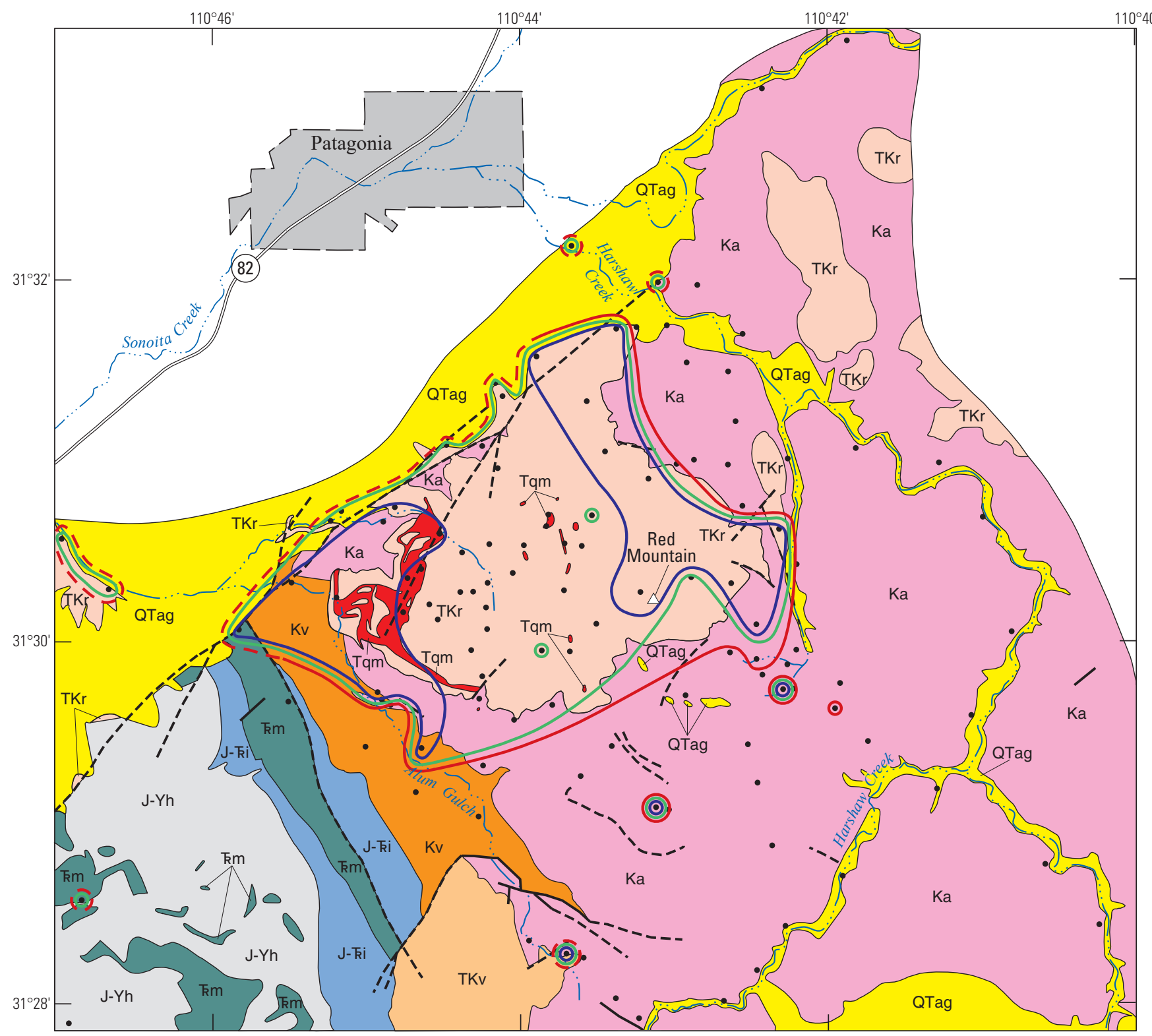

Figure 74. Distribution of sodium in rock samples

\section{EXPLANATION}

QTag Alluvium and terrace gravels undivided

Quartz monzonite porphyryIntrusive rocks

TKr Volcanics of Red Mountain - Chiefly rhyolite tuff. Drewes, 1971a; 1972

TKv Felsic volcanic rocks-Chiefly latite

Ka Trachyandesite of Meadow ValleyChiefly andesite porphyry.

Kv Silicic volcanics-Simons, 1974

J-ki Plutonic and volcanic rocks, undivided

Mount Wrightson Formation-Chiefly felsic volcanics

J-Yh Hornblende-rich metamorphic and

$$
\text { igneous rocks, undivided }
$$

Contact-Locally concealed or inferred

— Fault-Dashed where approximate or inferred

Distribution of sodium in rock samples, in percent-Contours are shown with a solid line where the sample density is high. Where sample density is low, the contours are dashed

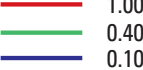

- Sample site

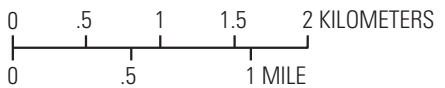

Base from U.S. Geological Survey digital data, 1:1,000,000, 2018 Geographic projection, decimal degrees North American Datum of 1927 and Simons (1974) 


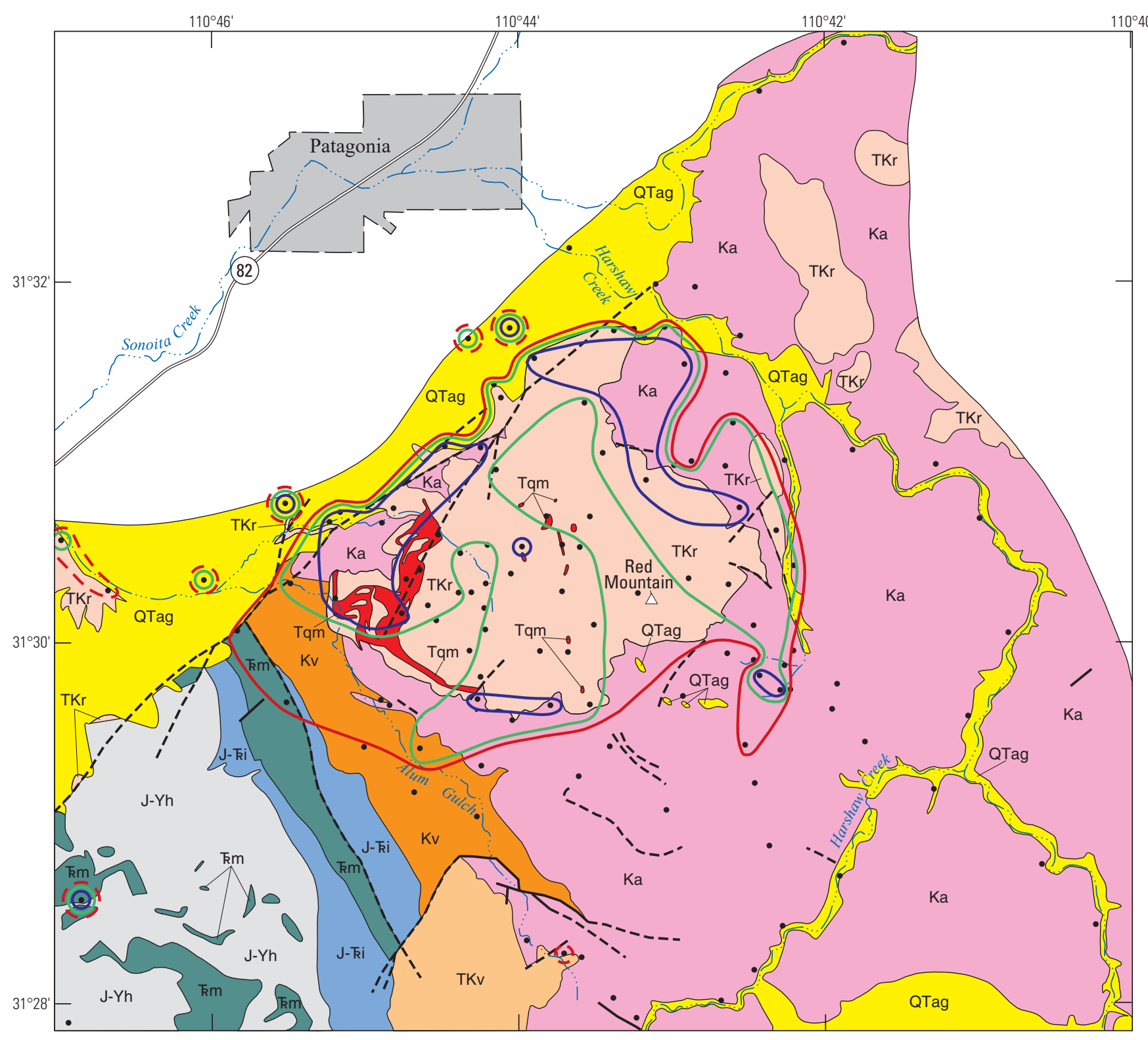

Figure 75. Distribution of sodium in soil samples.

\section{EXPLANATION}

QTag Alluvium and terrace gravels, undivided

Quartz monzonite porphyryIntrusive rocks

TKr Volcanics of Red Mountain-Chiefly rhyolite tuff. Drewes, 1971a; 1972

TKv Felsic volcanic rocks-Chiefly latite

$\mathrm{Ka}$ Trachyandesite of Meadow ValleyChiefly andesite porphyry. Simons, 1972

Kv Silicic volcanics-Simons, 1974

$\mathrm{J}$ - Ki Plutonic and volcanic rocks, undivided

Mount Wrightson Formation-Chiefly felsic volcanics

$\mathrm{J}-\mathrm{Yh}$ Hornblende-rich metamorphic and igneous rocks, undivided Contact-Locally concealed inferred

— Fault—Dashed where approximate or inferred

Distribution of sodium in soil samples, in percent-Contours are shown with solid line where the sample density is high. Where sample density is low, the contours are dashed

\section{$\begin{array}{r}0.70 \\ -\quad 0.50 \\ \hline\end{array}$}

$\longrightarrow \begin{array}{r}0.50 \\ 0.25\end{array}$

- Sample site

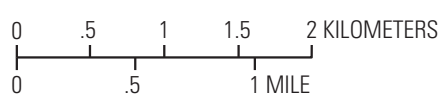

Base from U.S. Geological Survey digital data, 1:1,000,000, 2018 Geographic projection, decimal degrees

North American Datum of 1927

Geology modified from Drewes (1971a), Quinlan (1981, 1986), and Simons (1974). 


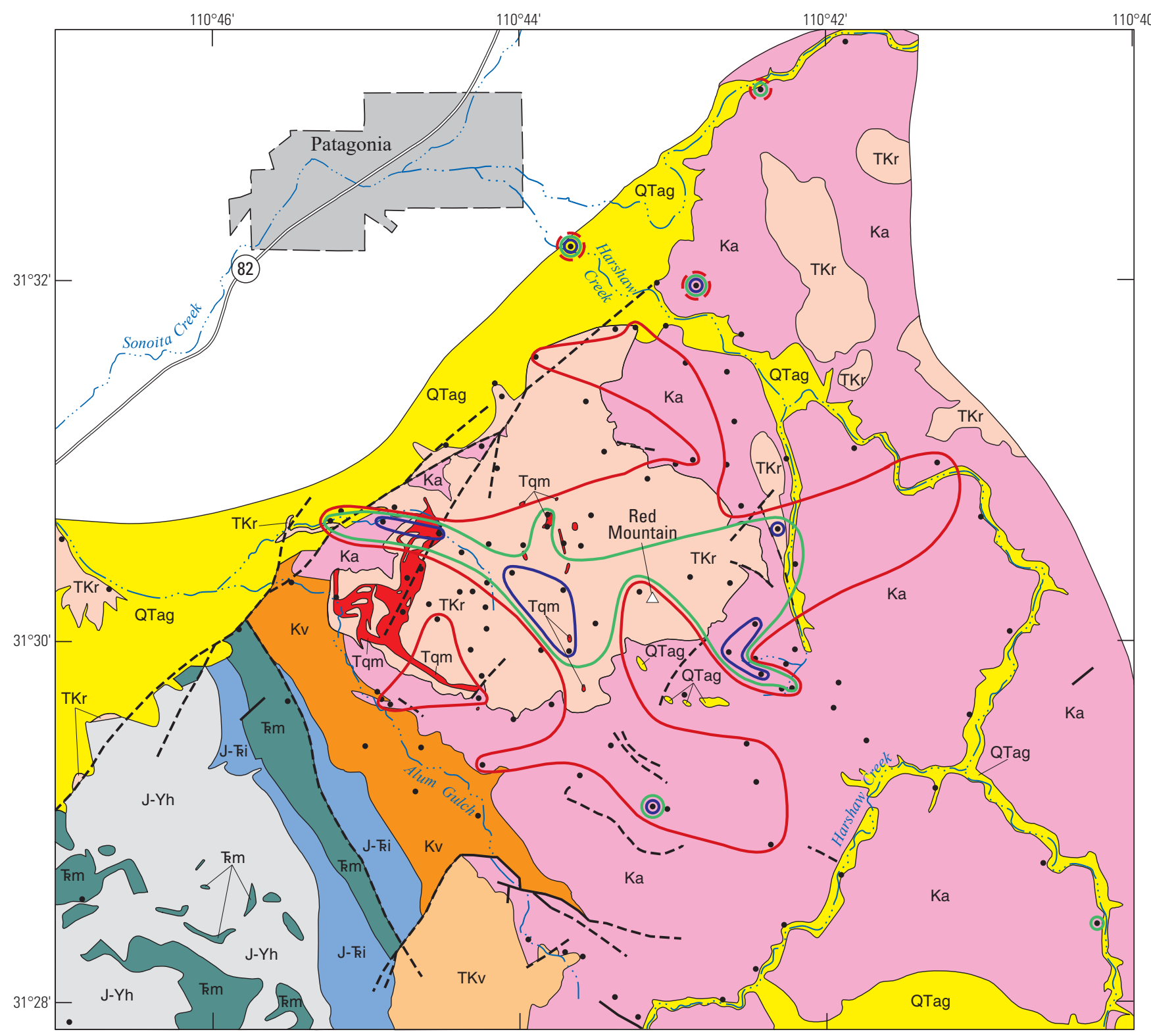

\section{EXPLANATION}

QTag Alluvium and terrace gravels undivided

Quartz monzonite porphyryIntrusive rocks

TKr Volcanics of Red Mountain - Chiefly rhyolite tuff. Drewes, 1971a; 1972

TKv Felsic volcanic rocks-Chiefly latite

$\mathrm{Ka}$ Trachyandesite of Meadow ValleyChiefly andesite porphyry. Simons, 1972

Kv Silicic volcanics-Simons, 1974

J-ki Plutonic and volcanic rocks, undivided

Mount Wrightson Formation-Chiefly felsic volcanics

$\mathrm{J}-\mathrm{Yh}$ Hornblende-rich metamorphic and

$$
\text { igneous rocks, undivided }
$$

Contact-Locally concealed or inferred

— Fault-Dashed where approximate or inferred

Distribution of potassium in rock samples in percent-Contours are shown with solid line where the sample density is high. Where sample density is low, the contours are dashed

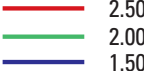

- $\quad$ Sample site

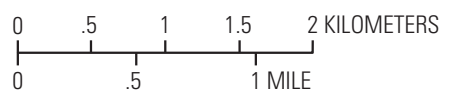

Base from U.S. Geological Survey digital data, 1:1,000,000, 2018 Geographic projection, decimal degrees North American Datum of 1927 and Simons (1974).

Figure 76. Distribution of potassium in rock samples. 


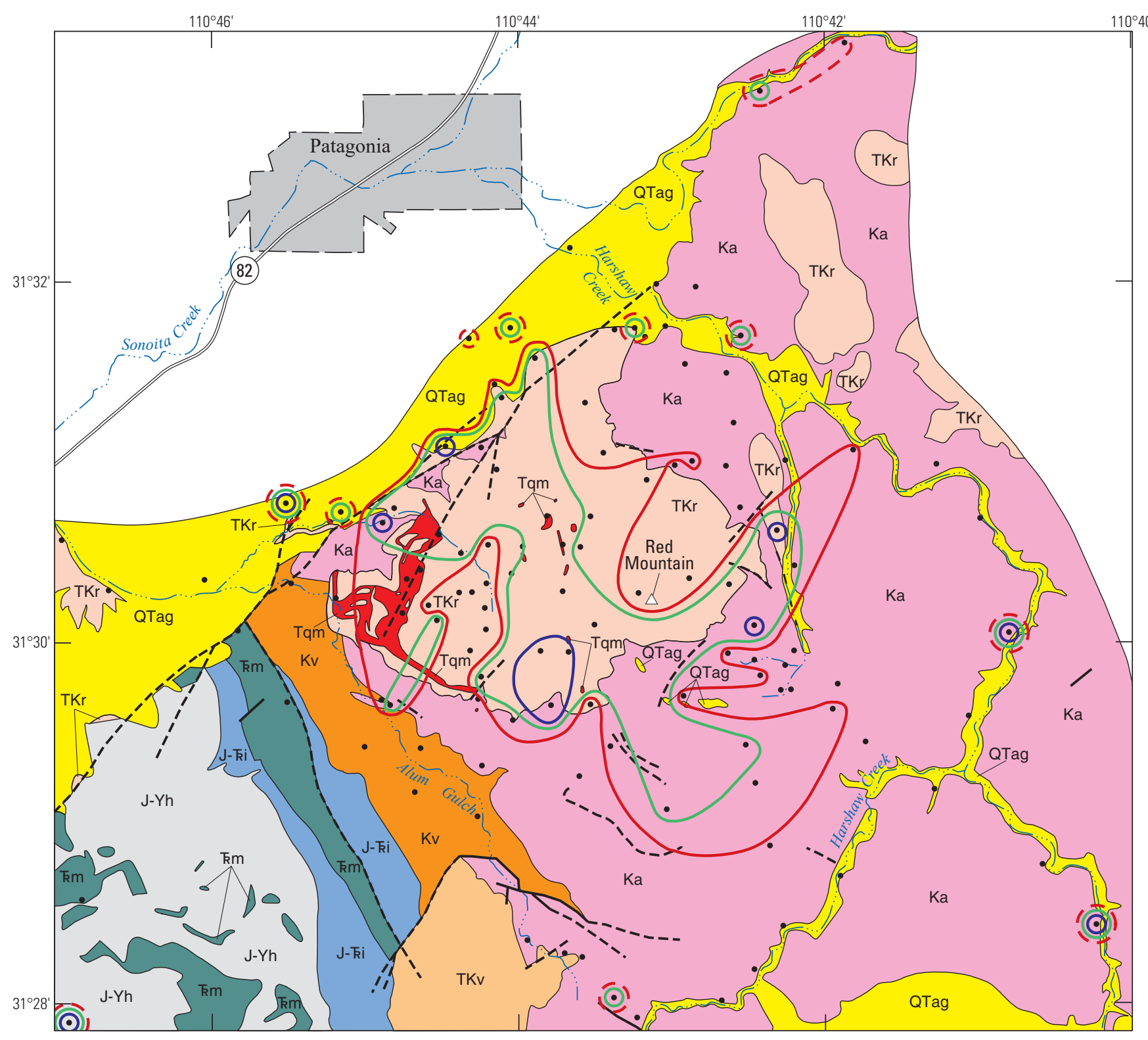

Figure 77. Distribution of potassium in soil samples.

\section{EXPLANATION}

QTag Alluvium and terrace gravels, undivided

Quartz monzonite porphyryIntrusive rocks

TKr Volcanics of Red Mountain-Chiefly rhyolite tuff. Drewes, 1971a; 1972

TKv Felsic volcanic rocks-Chiefly latite

$\mathrm{Ka}$ Trachyandesite of Meadow ValleyChiefly andesite porphyry. Simons, 1972

Kv Silicic volcanics-Simons, 1974

$\mathrm{J}$ - Ki Plutonic and volcanic rocks, undivided

Mount Wrightson Formation-Chiefly felsic volcanics

$\mathrm{J}-\mathrm{Yh}$ Hornblende-rich metamorphic and igneous rocks, undivided Contact-Locally concealed inferred

— Fault-Dashed where approximate or inferred

Distribution of potassium in soil samples, in percent-Contours are shown with a solid line where the sample density is high. Where sample density is low, the contours are dashed

2.10
1.90

$\longrightarrow \begin{array}{r}1.90 \\ -\quad 1.50\end{array}$

- Sample site

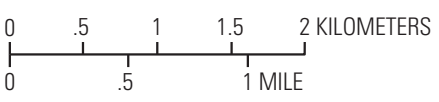

Base from U.S. Geological Survey digital data, 1:1,000,000, 2018 Geographic projection, decimal degrees

North American Datum of 1927

Geology modified from Drewes (1971a), Quinlan (1981, 1986). and Simons (1974). 
of iron in rock samples are centered over the cluster of small quartz monzonite porphyry outcrops that is directly above the deep hypogene Cu-Mo deposit (fig. 44). As discussed previously for copper, the widespread anomaly for iron along Harshaw Creek is likely a result of past mining contamination but some of the anomaly may be because of differences in iron concentrations because of lithologic variations within the andesite unit. In contrast to the distribution of iron in the rock samples, the highest iron concentrations in the soils are located over and around the main outcrop of quartz monzonite porphyry (fig. 45).

Molybdenum.-The median values for molybdenum in the rock and soil databases are 3 and $4 \mathrm{ppm}$, respectively (tables 4 and 5), indicating that molybdenum has probably been concentrated during soil formation. The highest molybdenum concentrations in both rock and soil samples are spatially associated with both the main outcrop of the quartz monzonite porphyry unit to the west and the cluster of small outcrops farther east (figs. 46 and 47). The rock map also identifies sites with molybdenum concentrations in the Harshaw Creek drainage that are probably related to contamination from past mining activities (Chaffee and others, 1981).

Silver, Arsenic, Antimony, Bismuth, Thallium, Lead, and Tellurium.-The median values for $\mathrm{Ag}, \mathrm{As}, \mathrm{Sb}, \mathrm{Bi}, \mathrm{Tl}, \mathrm{Pb}$, and Te in rock are $<0.5,12,1.0,<1.0,1.0,39$, and $0.2 \mathrm{ppm}$, respectively (table 4 ) and for these elements in soil are 0.3 , $34,3.0,1.0,1.5,112$, and $0.6 \mathrm{ppm}$, respectively (table 5).

Although the data for silver are not clear, it is likely that all of these elements have been concentrated during soil formation. The distributions of these deposit-related elements in the rock and soil samples are shown in figures 48-61. The rock maps all show complex distributions that are similar, positive anomalies, with the highest concentrations commonly in the general area of the cluster of small quartz monzonite porphyry outcrops in the center of the rhyolite tuff unit (figs. 48, 50, 52, 54, 56, 58 , and 60 for $\mathrm{Ag}, \mathrm{As}, \mathrm{Sb}, \mathrm{Bi}, \mathrm{Tl}, \mathrm{Pb}$, and Te, respectively). In contrast, the anomalies for many of these same seven elements in soil samples are somewhat more widespread than those seen for the comparable rock samples. Anomalies for most of these elements in soils include both the area of the main outcrop of quartz monzonite porphyry and that containing the cluster of small outcrops of the same unit (figs. 49, 51, 53, 55, 57, 59, and 61 for $\mathrm{Ag}, \mathrm{As}, \mathrm{Sb}, \mathrm{Bi}, \mathrm{Tl}, \mathrm{Pb}$, and Te, respectively). The high concentrations of arsenic in the deposit area (as much as $390 \mathrm{ppm}$ in rock and 1,500 ppm in soil; Horton and others, 2020) and of lead (as much as 2,370 ppm in rock and $1,490 \mathrm{ppm}$ in soil; Horton and others, 2020) are particularly noteworthy and emphasize that these two potentially toxic elements, in particular, have not been leached from the top of the deposit as a result of supergene enrichment and later weathering. The three scattered rock sites to the south of Red Mountain with highly anomalous silver, lead, and antimony in the rock samples are related to small areas prospected for base-metal silver deposits that may be part of a zone peripheral to the Red Mountain mineral system.
The high concentrations of arsenic (>100 ppm) and lead $(>800 \mathrm{ppm})$ in soil samples are particularly notable and emphasize that these elements, as well as many of the other deposit-related elements in this group have been relatively immobile chemically during weathering at Red Mountain. The effects of contamination for most of these elements in both sample types are only present in the upper part of the Harshaw Creek drainage.

All seven elements in this group also showed positive anomalies in core samples at the top of the section. Very few rock and soil samples were analyzed for tin and tungsten. However, their high, near-surface concentrations in the core samples imply that these two elements would also show deposit-related positive anomalies in the rock and soil samples.

Zinc and Cadmium.- The median values for zinc and cadmium are 74 and $0.06 \mathrm{ppm}$, respectively, in the rock database (table 4), and 103 and $0.25 \mathrm{ppm}$, respectively, in the soil database (table 5). These values clearly indicate that both elements have been concentrated during soil formation. These two elements in rock and soil samples (figs. 62-65) exhibit low concentrations over the hypogene $\mathrm{Cu}-\mathrm{Mo}$ deposit, consistent with the observation that low concentrations of zinc (and probably cadmium, for which data at depth are lacking) are present in core samples from the near-surface part of the deposit. These negative anomalies are present in both the rhyolite tuff and andesite units and locally in adjacent formations to the west. Some of this negative anomaly effect may be a result of pre-mineralization chemical differences between contrasting lithologies. Positive anomalies for cadmium and zinc are present locally for both media in the area surrounding the boundary for altered rocks and may represent a crude halo effect surrounding the central negative anomalies. Contamination effects have produced local negative anomalies in the peripheral drainage channels for both elements in both media, suggesting leaching of both elements.

Cobalt and Manganese.- The median values for cobalt and manganese are 5 and $144 \mathrm{ppm}$, respectively, in the rock database (table 4), and 9 and $571 \mathrm{ppm}$, respectively, in the soil database (table 5). Again, the soil values for both elements are distinctly higher than the rock values. These two elements also exhibit negative anomalies over the hypogene $\mathrm{Cu}-\mathrm{Mo}$ deposit in both rock and soil samples (figs. 66-69). The negative anomaly for cobalt is mainly a result of leaching of this element during the period of near-surface weathering that formed the leached cap. In the case of manganese, the distributions at depth (fig. 33), as well as at the surface, are mostly related to initially low concentrations of this element in the rhyolite tuff unit but may also include the effects of low concentrations as a result of leaching during formation of the leached cap. Manganese oxides are widely distributed in the indurated terrace gravels in the study area (fig. $4 D$ ).

Calcium, Magnesium, and Sodium.-The median values for calcium, magnesium, and sodium in rock samples are 0.12 , 0.32 , and 0.38 percent, respectively (table 4 ), and the values in soil samples are $0.45,0.47$, and 0.52 percent, respectively 
(table 5). All three elements have higher concentrations in the soils than rocks. These three major rock-forming elements exhibit distributions at depth that are closely related spatially to alteration associated with the hypogene $\mathrm{Cu}$-Mo deposit as well as to chemical differences because of weathering and contrasting lithologies. On the surface directly over the deposit area, all three elements exhibit complex negative anomalies in both the rock and soil samples (figs. 70-75).

Potassium.-Potassium is also a major constituent of the bulk chemistry of the various volcanic host rocks, as well as being associated with hydrothermal potassic alteration and with the major sulfide mineralization events at Red Mountain. The median value for potassium is 2.56 percent in rock (table 4 ) and 2.19 percent in soil (table 5). Unlike all of the other selected elements, potassium is somewhat depleted in the soil samples as compared to the rock samples. Potassium concentrations in both rock and soil samples exhibit complex, mostly lithology-associated negative anomalies that are generally centered on the rhyolite tuff unit but extend locally into the andesite unit (figs. 76 and 77). The high concentrations $(>2.50$ percent for rocks and $>2.10$ percent for soils) of potassium outside of the area of visible alteration on both plots are thought to simply represent relatively high but normal concentrations of potassium in the generally unaltered parts of the andesite unit.

\section{Distribution of Percent Ash and Selected Elements in Vegetation Samples}

The elements selected for illustrating distributions in vegetation include 10 hypogene deposit-related elements (Ag, $\mathrm{As}, \mathrm{Bi}, \mathrm{Cd}, \mathrm{Cu}, \mathrm{Mo}, \mathrm{Pb}, \mathrm{Sb}, \mathrm{Se}$, and $\mathrm{Zn}$ ) and 3 elements more closely related to lithology ( $\mathrm{Mg}, \mathrm{Mn}$, and $\mathrm{Na}$ ). Some elements highlighted in the rock and soil discussion are not included in this section because they did not show any interpretable distributions or had restricted ranges of values. Percent ash maps for the mesquite, oak, and juniper are included to demonstrate that their distributions are totally independent of the effects of the chemical history of the hypogene $\mathrm{Cu}-\mathrm{Mo}$ deposit and also of the various lithologies.

The distributions for percent ash and these 13 elements in the 3 plant species are shown in figures 78-119. Contour values for each vegetation map were chosen somewhat arbitrarily in order to best illustrate the distribution of a given element in each species. In general, the lowest contour value plotted on each map is close to the median concentration value for that element. As was the case for rock and soil samples, some of the vegetation maps show anomalies associated with the Harshaw Creek and Alum Gulch drainages that are likely a result of water, soil, and (or) airborne contamination related to past mining (Chaffee and others, 1981).
Percent Ash-Because of the limited ranges of values for percent ash in the three plant species, the distributions are difficult to contour. The median values for percent ash in mesquite, oak, and juniper samples are 5.70, 3.95, and 4.78 percent, respectively (tables 6-8), The mesquite and oak ash produced positive anomalies that are centered mostly east (mesquite) or south (oak) of Red Mountain (figs. 78 and 79, respectively). In contrast, juniper ash produced a negative anomaly that is roughly centered over and south of the rhyolite tuff unit (fig. 80). These distributions are species dependent and are not associated with the chemical distributions related either to the mineral deposit or to specific lithologies. The distributions are thus mostly related to physical environmental conditions, such as annual precipitation, annual temperature, elevation, slope angle, aspect, and available groundwater.

Copper, Molybdenum, and Silver-Copper and molybdenum are essential elements for plants; silver is considered to be nonessential (Brooks, 1983). The A/B (ash/soil) ratios exceed 1.00 for copper and molybdenum in mesquite, for silver in oak, and for molybdenum in juniper (tables 6-8). Previous studies have also shown accumulation of copper and molybdenum in mesquite (Chaffee, 1976a; Huff, 1970). Published data for oak and juniper are lacking.

The median values for copper are 147, 87, and 62 ppm for mesquite, oak, and juniper ash, respectively; for molybdenum are 5.3, 1.6, and $5.0 \mathrm{ppm}$, respectively; and for silver are 0.27 , 0.42 , and $0.15 \mathrm{ppm}$, respectively (tables 6-8). Positive anomalies of copper, molybdenum, and silver in ash samples of all three species are generally centered over the rhyolite tuff unit and, in many cases, directly over the hypogene $\mathrm{Cu}-\mathrm{Mo}$ deposit (figs. 81-89, respectively). The distributions of anomalies in the mesquite ash samples are not well defined in the center of the rhyolite tuff unit because of the lack of sample sites in that formation at the higher elevations. High concentrations of all three elements in oak ash samples are mostly centered over the main exposure of quartz monzonite porphyry and, to a lesser extent, over the area with the cluster of small outcrops of this same formation. In contrast to their distributions in mesquite and oak ash, the copper, molybdenum, and silver anomalies for juniper ash (figs. 83, 86, and 89, respectively) are mostly centered over the cluster of small quartz monzonite porphyry outcrops in the middle of the rhyolite tuff unit. The reason for these differences among the species is not clear.

Arsenic, Antimony, and Bismuth.-These three elements are an important part of the hydrothermal mineral suite at Red Mountain, but they are not essential for plants; they are generally considered to be toxic (Levinson, 1974). This nonessential nature of these elements is emphasized with the mostly low ash/soil ratio values (columns A/B) for these elements, which range from 0.04 to 0.07 in mesquite ash, from 0.06 to 0.47 in oak ash, and from 0.07 to 0.16 in juniper ash (tables 6-8). The low ratio values emphasize that these species are not strongly accumulating these potentially toxic elements. Despite this fact, all of these elements, except for antimony in mesquite, exhibit well-defined positive anomalies (figs. 90-98), 


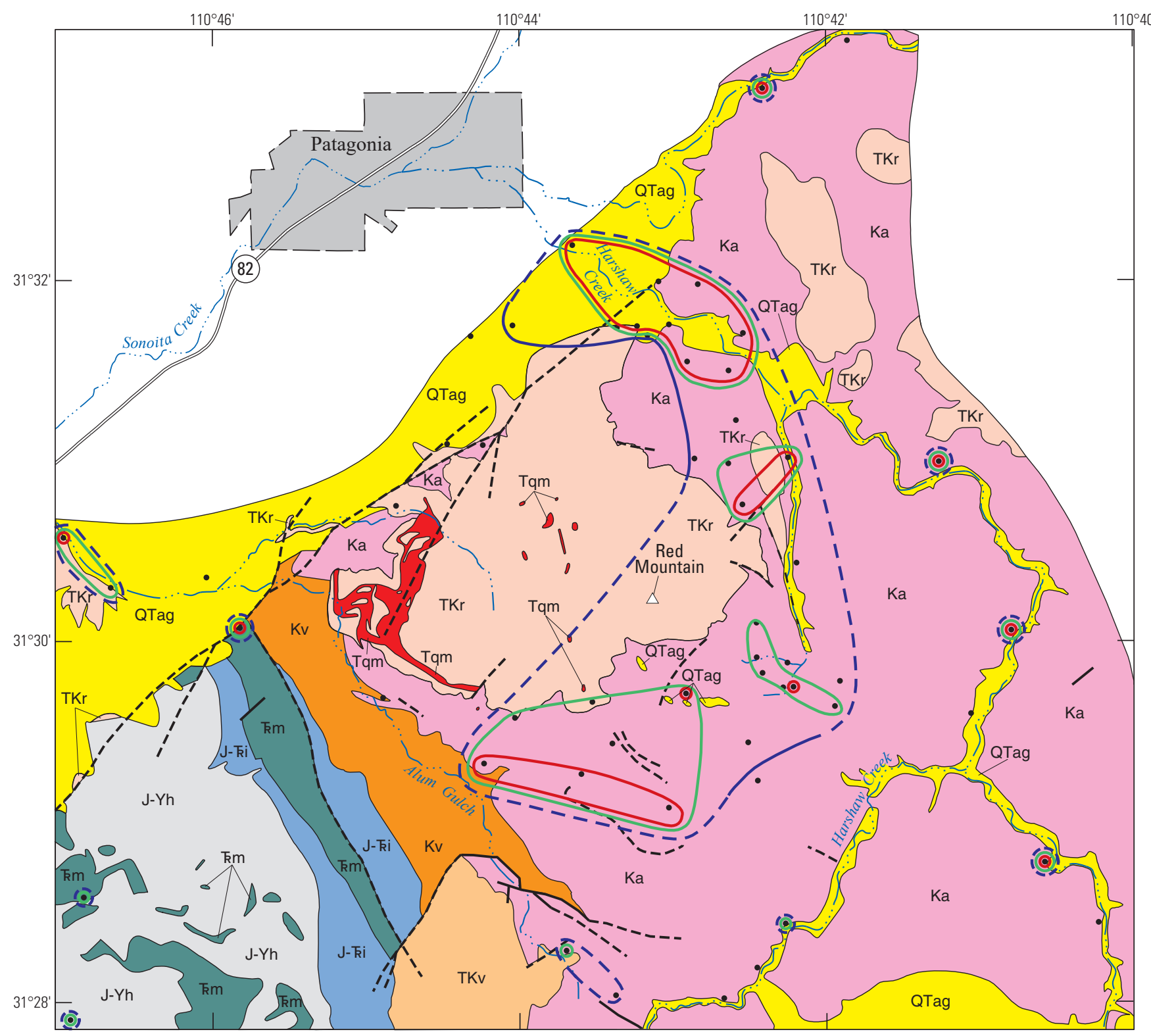

\section{EXPLANATION}

QTag Alluvium and terrace gravels undivided

Quartz monzonite porphyryIntrusive rocks

TKr Volcanics of Red Mountain - Chiefly rhyolite tuff. Drewes, 1971a; 1972

TKv Felsic volcanic rocks-Chiefly latite

Ka Trachyandesite of Meadow ValleyChiefly andesite porphyry. Simons, 1972

Kv Silicic volcanics-Simons, 1974

J-ki Plutonic and volcanic rocks, undivided

Mount Wrightson Formation-Chiefly felsic volcanics

$\mathrm{J}$-Yh Hornblende-rich metamorphic and

$$
\text { igneous rocks, undivided }
$$

Contact-Locally concealed or inferred

— Fault-Dashed where approximate or inferred

Distribution of ash in mesquite samples, in percent-Contours are shown with solid line where the sample density is high. Where sample density is low, the contours are dashed

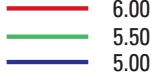

- Sample site

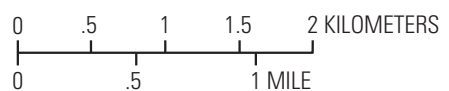

Base from U.S. Geological Survey digital data, 1:1,000,000, 2018 Geographic projection, decimal degrees North American Datum of 1927 and Simons (1974)

Figure 78. Distribution of percent ash in mesquite samples. 




Figure 79. Distribution of percent ash in oak samples.

\section{EXPLANATION}

QTag Alluvium and terrace gravels undivided

Quartz monzonite porphyryIntrusive rocks

TKr Volcanics of Red Mountain—Chiefly rhyolite tuff. Drewes, 1971a; 1972

TKv Felsic volcanic rocks-Chiefly latite

$\mathrm{Ka}$ Trachyandesite of Meadow ValleyChiefly andesite porphyry. Simons, 1972

Kv Silicic volcanics-Simons, 1974

$\mathrm{J}$ - Ki Plutonic and volcanic rocks, undivided

Mount Wrightson Formation-Chiefly felsic volcanics

$\mathrm{J}-\mathrm{Yh}$ Hornblende-rich metamorphic and igneous rocks, undivided Contact-Locally concealed inferred

Fault-Dashed where approximate or inferred

Distribution of ash in oak samples, in percent-Contours are shown with a solid line where the sample density is high. Where sample density is low, the contours are dashed

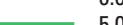

- Sample site

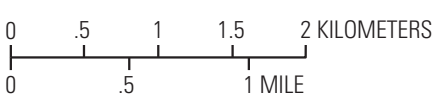

Base from U.S. Geological Survey digital data, 1:1,000,000, 2018 Geographic projection, decimal degrees

North American Datum of 1927

Geogy modified from Drewes (1971a), Quinlan $(1981,1986)$, and Simons (1974). 


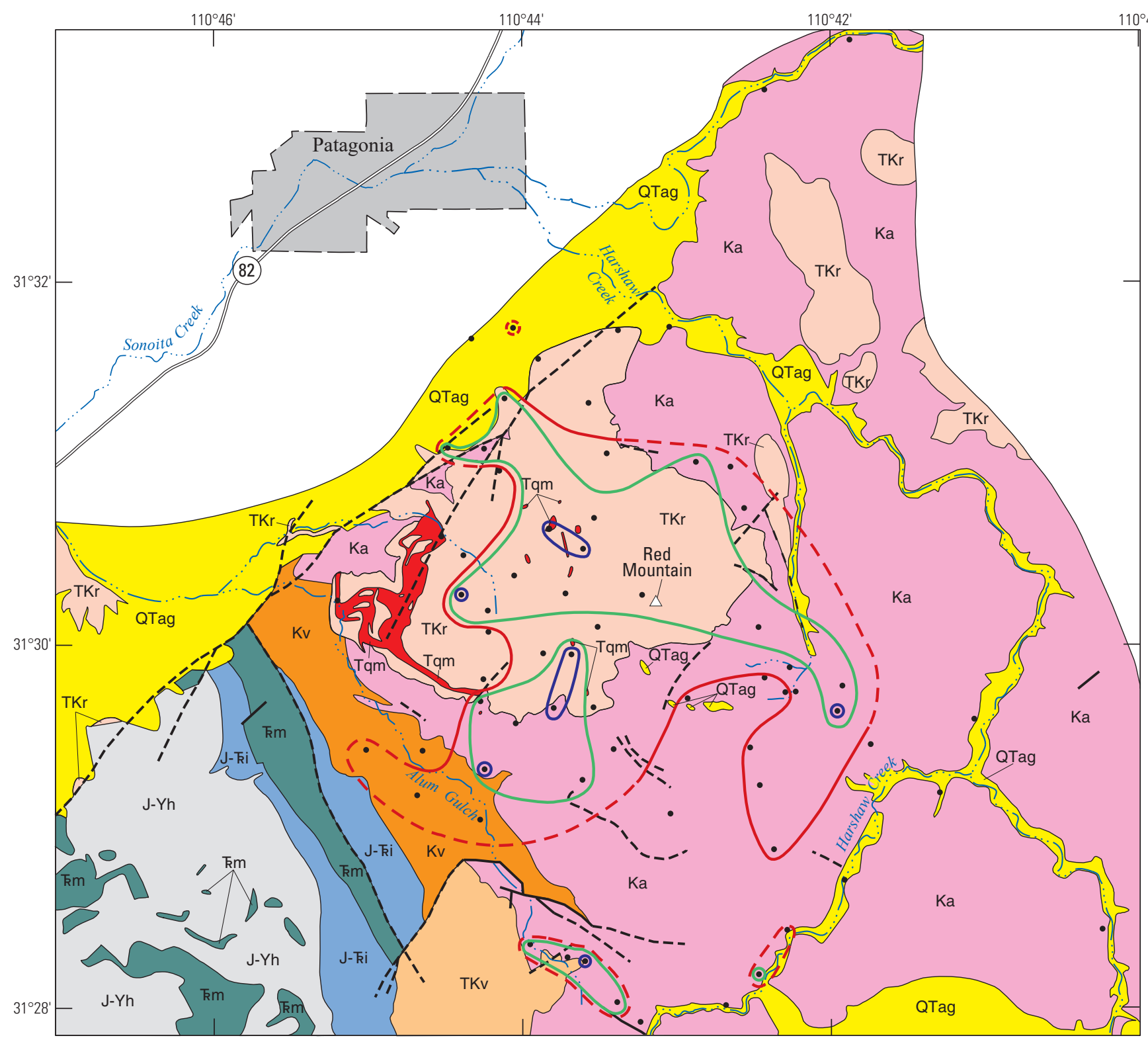

\section{EXPLANATION}

QTag Alluvium and terrace gravels undivided

Quartz monzonite porphyryIntrusive rocks

TKr Volcanics of Red Mountain - Chiefly rhyolite tuff. Drewes, 1971a; 1972

TKv Felsic volcanic rocks-Chiefly latite

Ka Trachyandesite of Meadow ValleyChiefly andesite porphyry.

$$
\text { Simons, } 1972
$$

Kv Silicic volcanics-Simons, 1974

J-ki Plutonic and volcanic rocks, undivided

Mount Wrightson Formation-Chiefly felsic volcanics

$\mathrm{J}-\mathrm{Yh}$ Hornblende-rich metamorphic and

$$
\text { igneous rocks, undivided }
$$

Contact-Locally concealed or inferred

— Fault-Dashed where approximate or inferred

Distribution of ash in juniper samples, in percent-Contours are shown with a solid line where the sample density is high. Where sample density is low, the contours are dashed

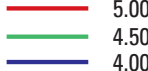

- 4.00

- $\quad$ Sample site

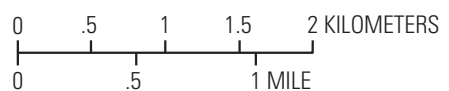

Base from U.S. Geological Survey digital data, 1:1,000,000, 2018 Geographic projection, decimal degrees North American Datum of 1927 and Simons (1974).

Figure 80. Distribution of percent ash in juniper samples. 


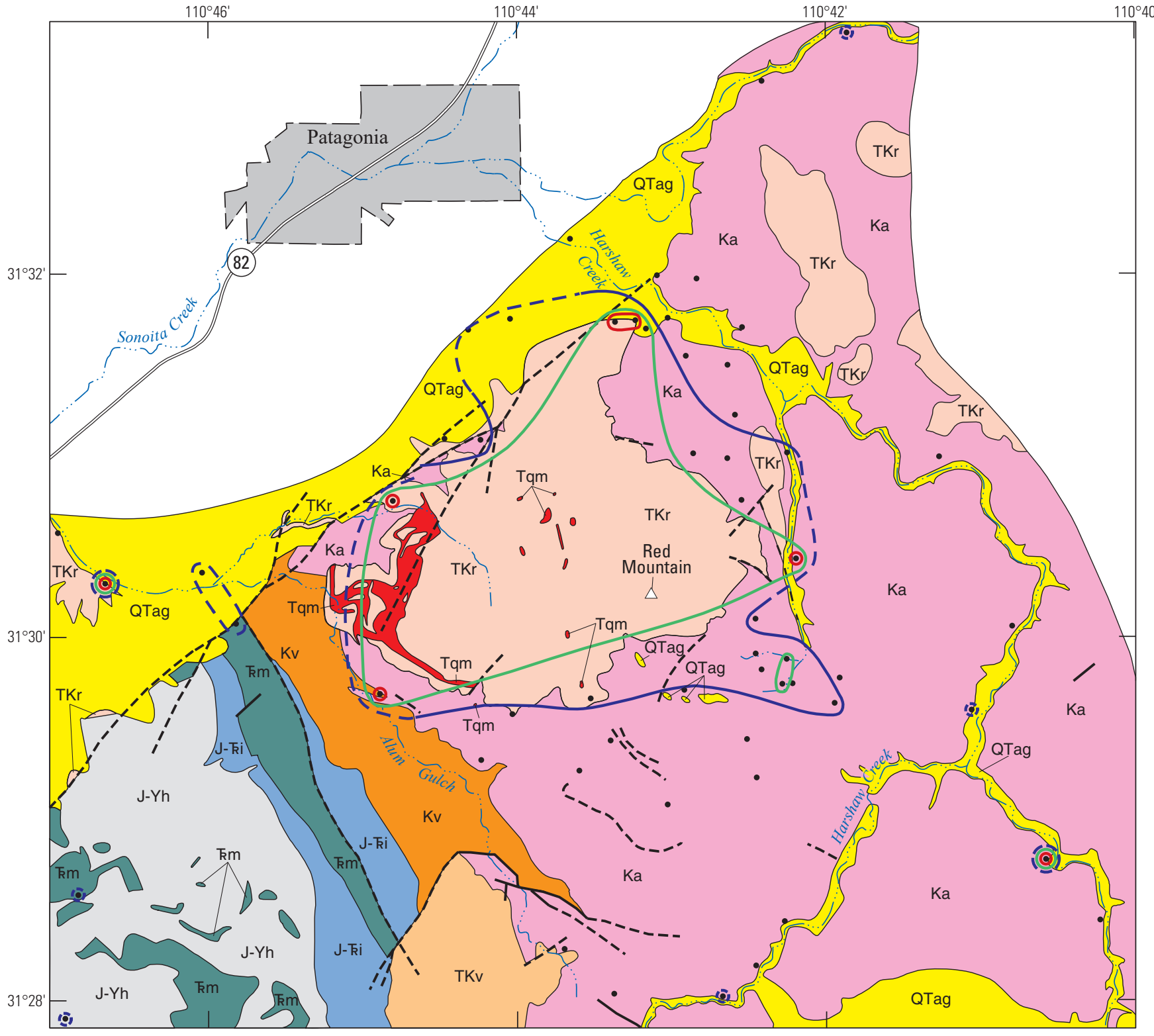

Figure 81. Distribution of copper in oak ash.

\section{EXPLANATION}

QTag Alluvium and terrace gravels, undivided

Quartz monzonite porphyryIntrusive rocks

TKr Volcanics of Red Mountain-Chiefly rhyolite tuff. Drewes, 1971a; 1972

TKv Felsic volcanic rocks-Chiefly latite

$\mathrm{Ka}$ Trachyandesite of Meadow ValleyChiefly andesite porphyry. Simons, 1972

Kv Silicic volcanics-Simons, 1974

$\mathrm{J}-\mathrm{Ki}$ Plutonic and volcanic rocks, undivided

Mount Wrightson Formation-Chiefly felsic volcanics

$\mathrm{J}-\mathrm{Yh}$ Hornblende-rich metamorphic and igneous rocks, undivided Contact-Locally concealed or inferred

Fault-Dashed where approximate or inferred

Distribution of copper in mesquite ash, in parts per million-Contours are shown with a solid line where the sample density is high. Where sample density is

$-200$

175
$-\quad 150$

- Sample site

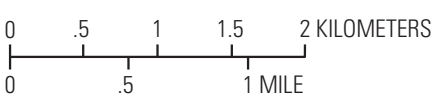

Base from U.S. Geological Survey digital data, 1:1,000,000, 2018 Geographic projection, decimal degrees

North American Datum of 1927

Geology modified from Drewes (1971a), Quinlan (1981, 1986), and Simons (1974). 


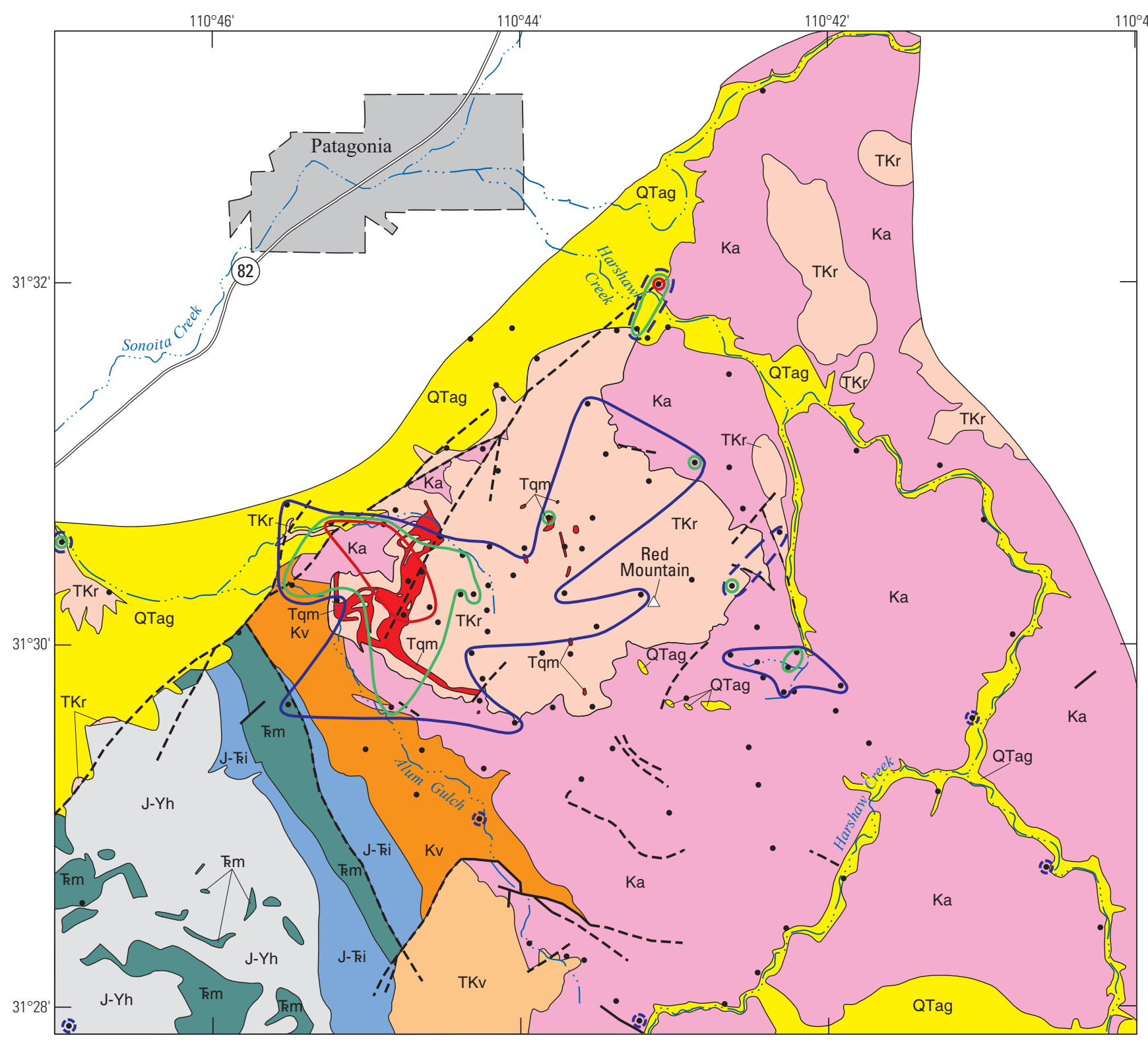

\section{EXPLANATION}

QTag Alluvium and terrace gravels, undivided

Quartz monzonite porphyryIntrusive rocks

TKr Volcanics of Red Mountain - Chiefly rhyolite tuff. Drewes, 1971a; 1972

TKv Felsic volcanic rocks-Chiefly latite

$\mathrm{Ka}$ Trachyandesite of Meadow ValleyChiefly andesite porphyry.

$$
\text { Simons, } 1972
$$

Kv Silicic volcanics-Simons, 1974

$\mathrm{J}-\mathrm{ki}$ Plutonic and volcanic rocks. undivided

Mount Wrightson Formation-Chiefly felsic volcanics

$\mathrm{J}$-Yh Hornblende-rich metamorphic and igneous rocks, undivided Contact-Locally concealed or inferred

ault-Dashed where approximat or inferred

Distribution of copper in oak ash, in parts per million-Contours are shown with a solid line where the sample density is high. Where sample density is low, the tours are dashed

\begin{tabular}{c}
140 \\
\hline
\end{tabular}

- Sample site

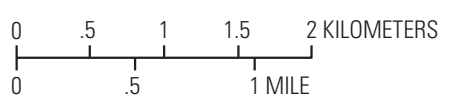

Base from U.S. Geological Survey digital data, 1:1,000,000, 2018 Geographic projection, decimal degrees North American Datum of 1927

Geology modified from Drewes (1971a), Quinlan (1981, 1986) and Simons (1974)

Figure 82. Distribution of copper in mesquite ash. 


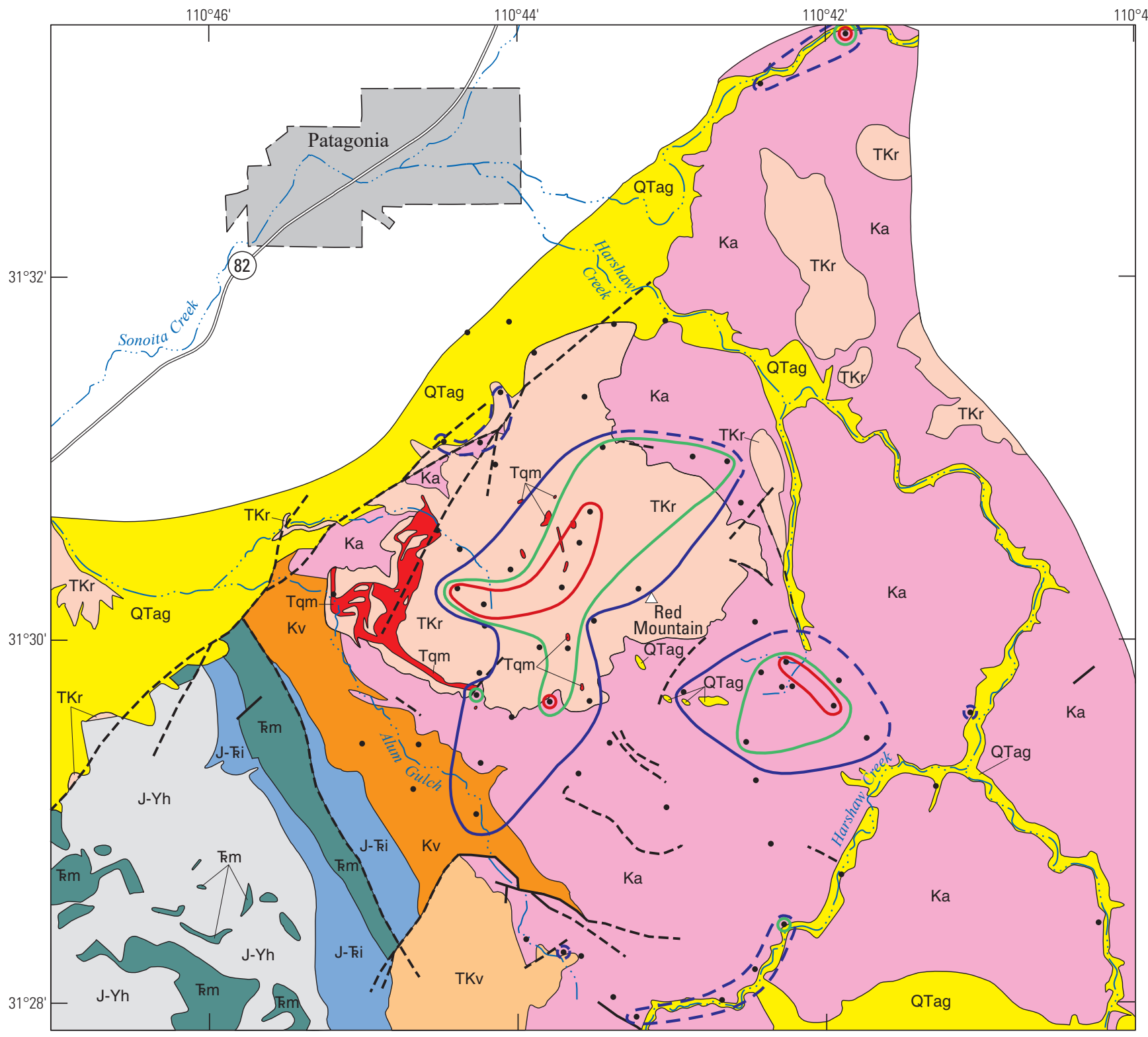

\section{EXPLANATION}

QTag Alluvium and terrace gravels, undivided

Quartz monzonite porphyryIntrusive rocks

TKr Volcanics of Red Mountain - Chiefly rhyolite tuff. Drewes, 1971a; 1972

TKv Felsic volcanic rocks-Chiefly latite

$\mathrm{Ka}$ Trachyandesite of Meadow ValleyChiefly andesite porphyry. Simons, 1972

Kv Silicic volcanics-Simons, 1974

$\mathrm{J}$ - $\mathrm{Ki}$ Plutonic and volcanic rocks, undivided

Mount Wrightson Formation-Chiefly felsic volcanics

$\mathrm{J}-\mathrm{Yh}$ Hornblende-rich metamorphic and igneous rocks, undivided Contact-Locally concealed or inferred

Fault-Dashed where approximate or inferred

Distribution of copper in juniper ash, in parts per million-Contours are shown parts per million-Contours are shown
with a solid line where the sample density is high. Where sample density is low, the contours are dashed

$\begin{array}{r}-\quad 80 \\ -\quad 70 \\ \hline\end{array}$

$\begin{array}{r}70 \\ \hline\end{array} 60$

- Sample sit

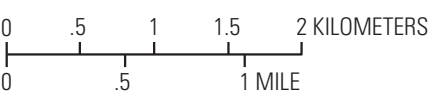

Base from U.S. Geological Survey digital data, 1:1,000,000, 2018 Geographic projection, decimal degrees

North American Datum of 1927

Geology modified from Drewes (1971a), Quinlan (1981, 1986) and Simons (1974).

Figure 83. Distribution of copper in juniper ash. 


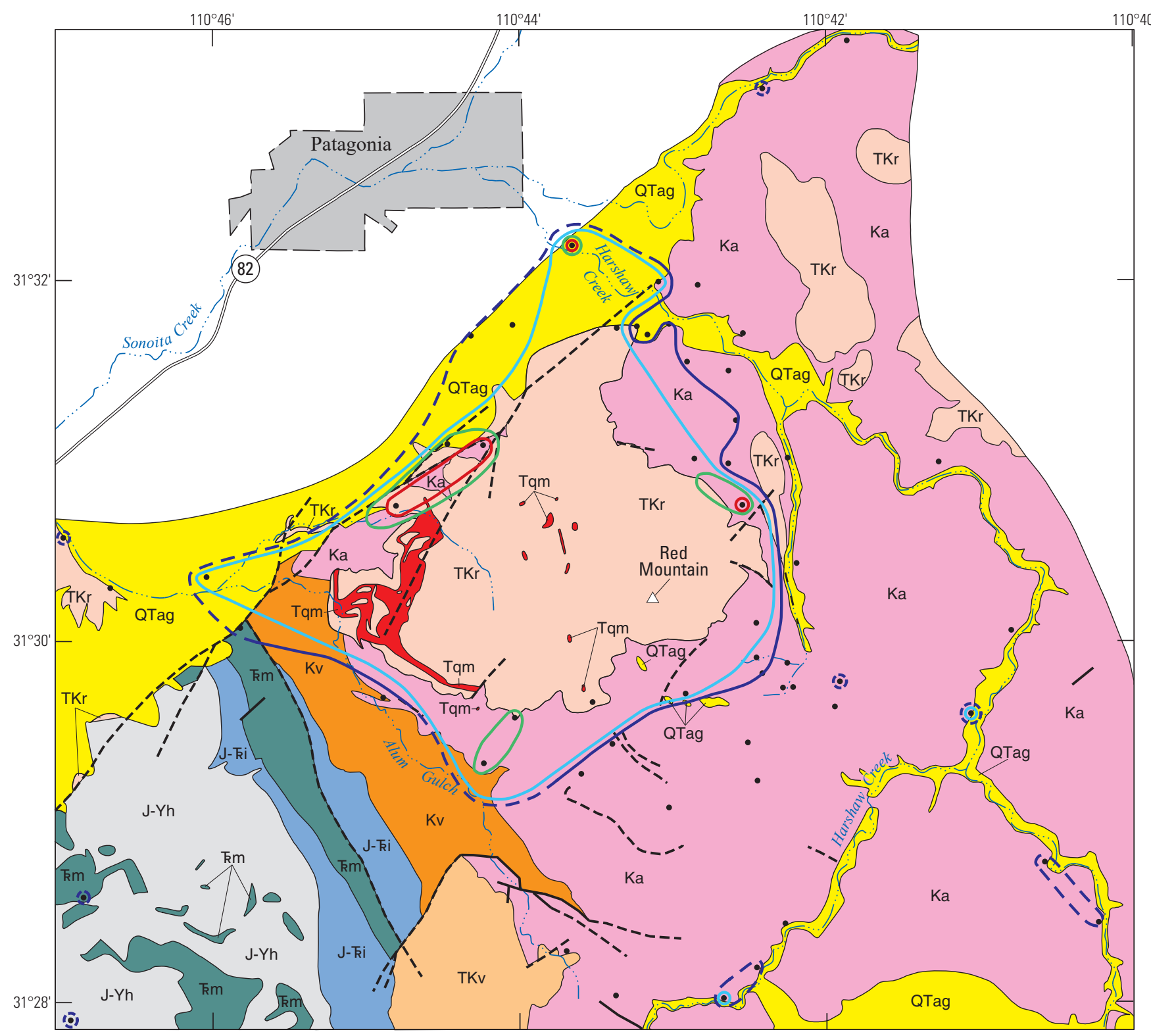

\section{EXPLANATION}

QTag Alluvium and terrace gravels undivided

Quartz monzonite porphyryIntrusive rocks

TKr Volcanics of Red Mountain - Chiefly rhyolite tuff. Drewes, 1971a; 1972

TKv Felsic volcanic rocks-Chiefly latite

Ka Trachyandesite of Meadow ValleyChiefly andesite porphyry. Simons, 1972

Kv Silicic volcanics-Simons, 1974

J-ki Plutonic and volcanic rocks, undivided

Mount Wrightson Formation-Chiefly felsic volcanics

$\mathrm{J}$-Yh Hornblende-rich metamorphic and

$$
\text { igneous rocks, undivided }
$$
inferred

_ Fault-Dashed where approximate or inferred

Distribution of molybdenum in mesquite ash, in parts per million-Contours are shown with a solid line where the sample density is high. Where sample
density is low, the contours are dashed

\begin{tabular}{ll}
$\square$ & 40 \\
$\square$ & 20 \\
\hline & 10 \\
\hline & 5
\end{tabular}

- $\quad$ Sample site

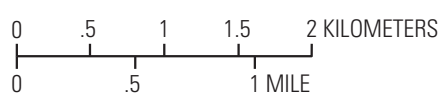

Base from U S. Geological Survey digital data, 1:1,000,000, 2018 Geographic projection, decimal degrees North American Datum of 1927 and Simons (1974).

Figure 84. Distribution of molybdenum in mesquite ash. 


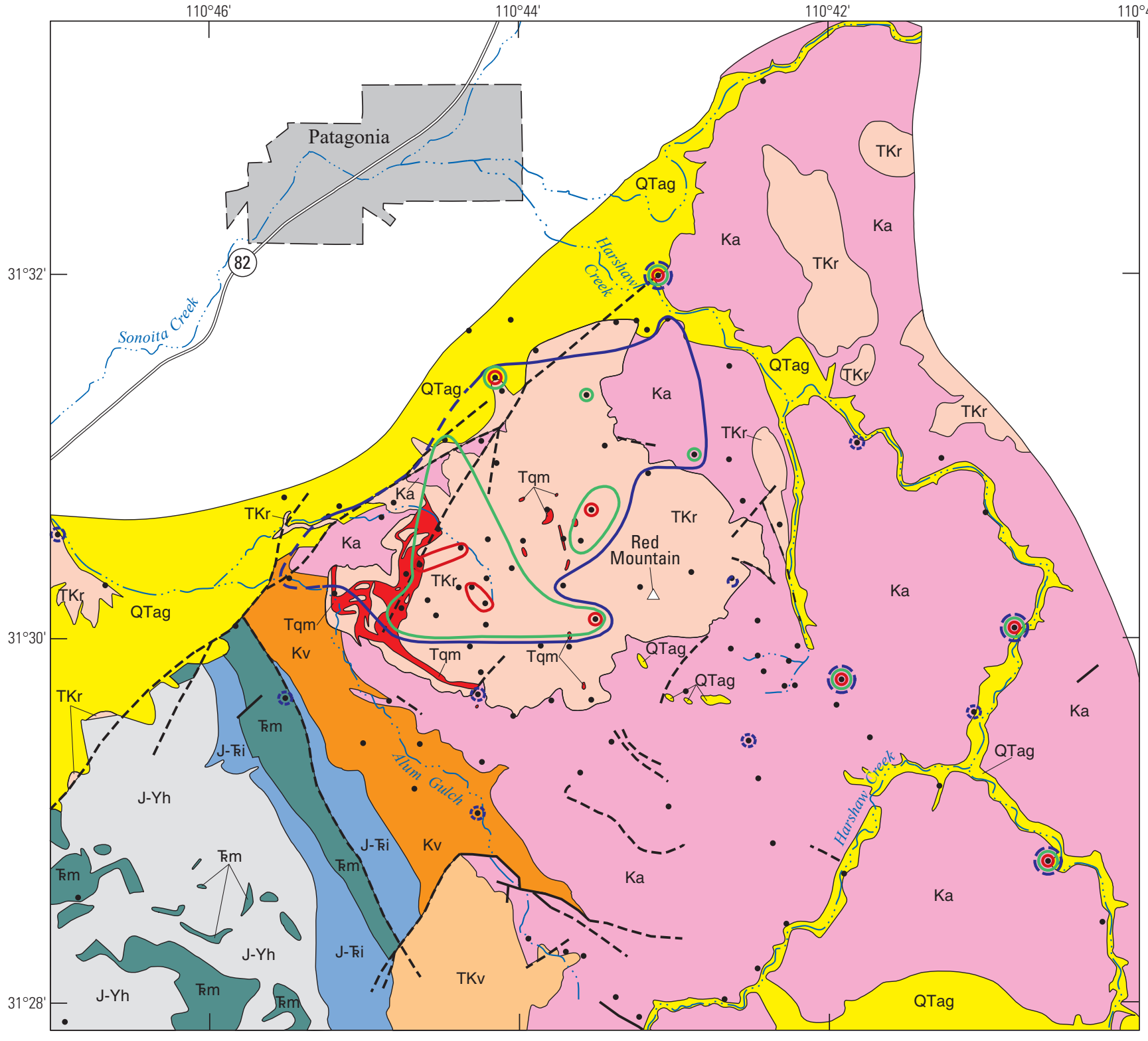

Figure 85. Distribution of molybdenum in oak ash.

\section{EXPLANATION}

QTag Alluvium and terrace gravels undivided

Quartz monzonite porphyryIntrusive rocks

Volcanics of Red Mountain-Chiefly rhyolite tuff. Drewes, 1971a; 1972

TKv Felsic volcanic rocks-Chiefly latite

Ka Trachyandesite of Meadow ValleyChiefly andesite porphyry. Simons, 1972

Kv Silicic volcanics-Simons, 1974

$\mathrm{J}$ - $\mathrm{ki}$ Plutonic and volcanic rocks, undivided

Mount Wrightson Formation-Chiefly felsic volcanics

$\mathrm{J}-\mathrm{Yh}$ Hornblende-rich metamorphic and igneous rocks, undivided Contact-Locally concealed inferred

Fault-Dashed where approximate or inferred

Distribution of molybdenum in oak ash, in parts per million-Contours are shown with a solid line where the sample density is high. Where sample density is low, the contours are dashed

2.5
$-\quad 2.0$
1.5

- Sample site

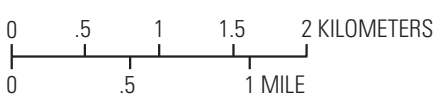

Base from U.S. Geological Survey digital data, 1:1,000,000, 2018 Geographic projection, decimal degrees

North American Datum of 1927

Geology modified from Drewes (1971a), Quinlan (1981, 1986) and Simons (1974). 


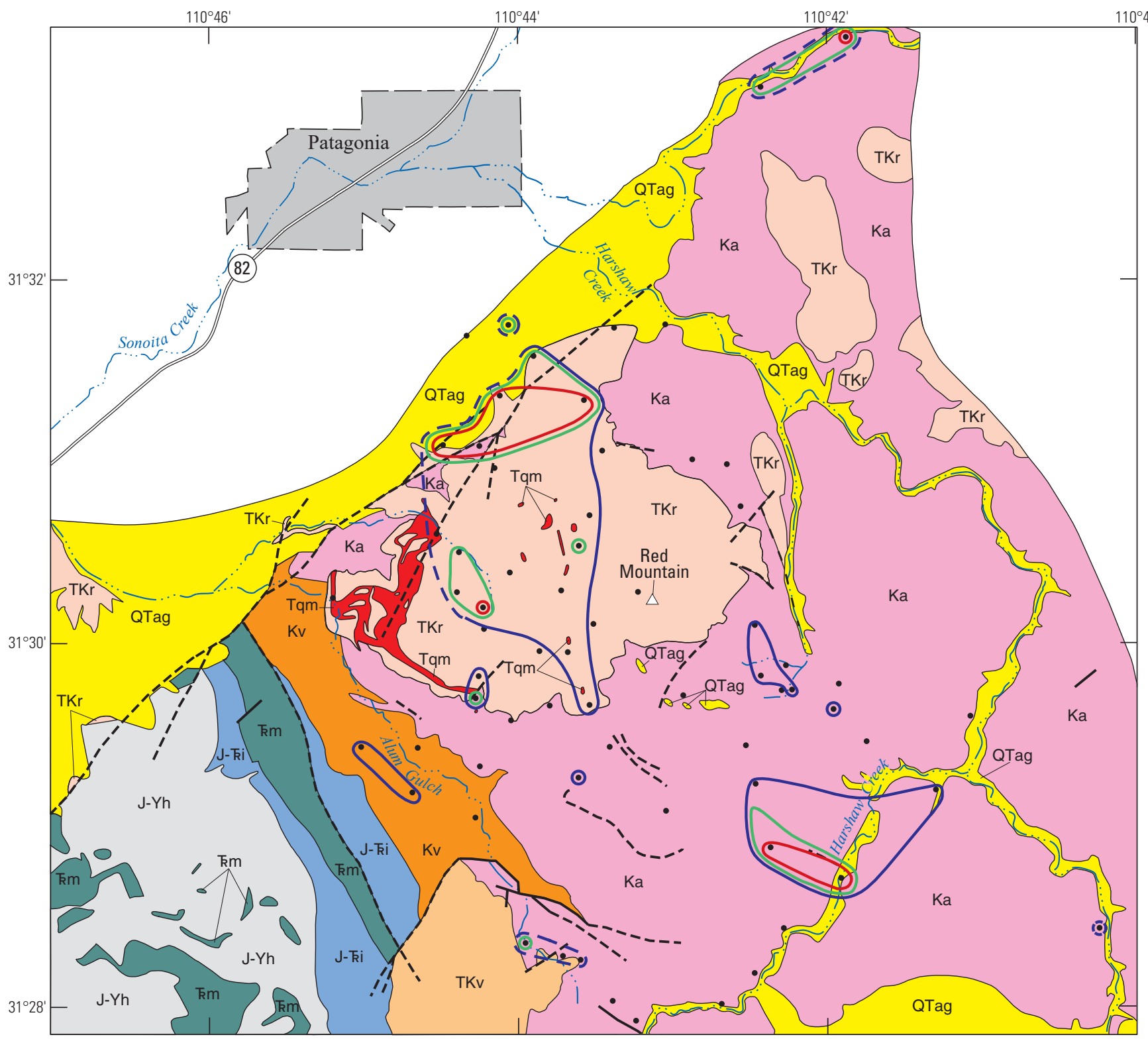

QTag Alluvium and terrace gravels, undivided

Quartz monzonite porphyryIntrusive rocks

TKr Volcanics of Red Mountain—Chiefly rhyolite tuff. Drewes, 1971a; 1972

TKv Felsic volcanic rocks-Chiefly latite

$\mathrm{Ka}$ Trachyandesite of Meadow ValleyChiefly andesite porphyry. Simons, 1972

Kv Silicic volcanics-Simons, 1974

$\mathrm{J}$ - $\mathrm{ki}$ Plutonic and volcanic rocks, undivided

Mount Wrightson Formation-Chiefly felsic volcanics

$\mathrm{J}-\mathrm{Yh}$ Hornblende-rich metamorphic and

$$
\text { igneous rocks, undivided }
$$

Contact-Locally concealed or

$$
\text { inferred }
$$

_ Fault-Dashed where approximate or inferred

Distribution of molybdenum in juniper ash, in parts per million-Contours are shown with a solid line where the sample density is high. Where sample density is low, the contours are dashed

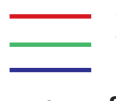
9
7

- $\quad$ Sample site

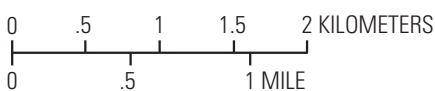

Base from U.S. Geological Survey digital data, 1:1,000,000, 2018 Geographic projection, decimal degrees North American Datum of 1927

Figure 86. Distribution of molybdenum in juniper ash. 


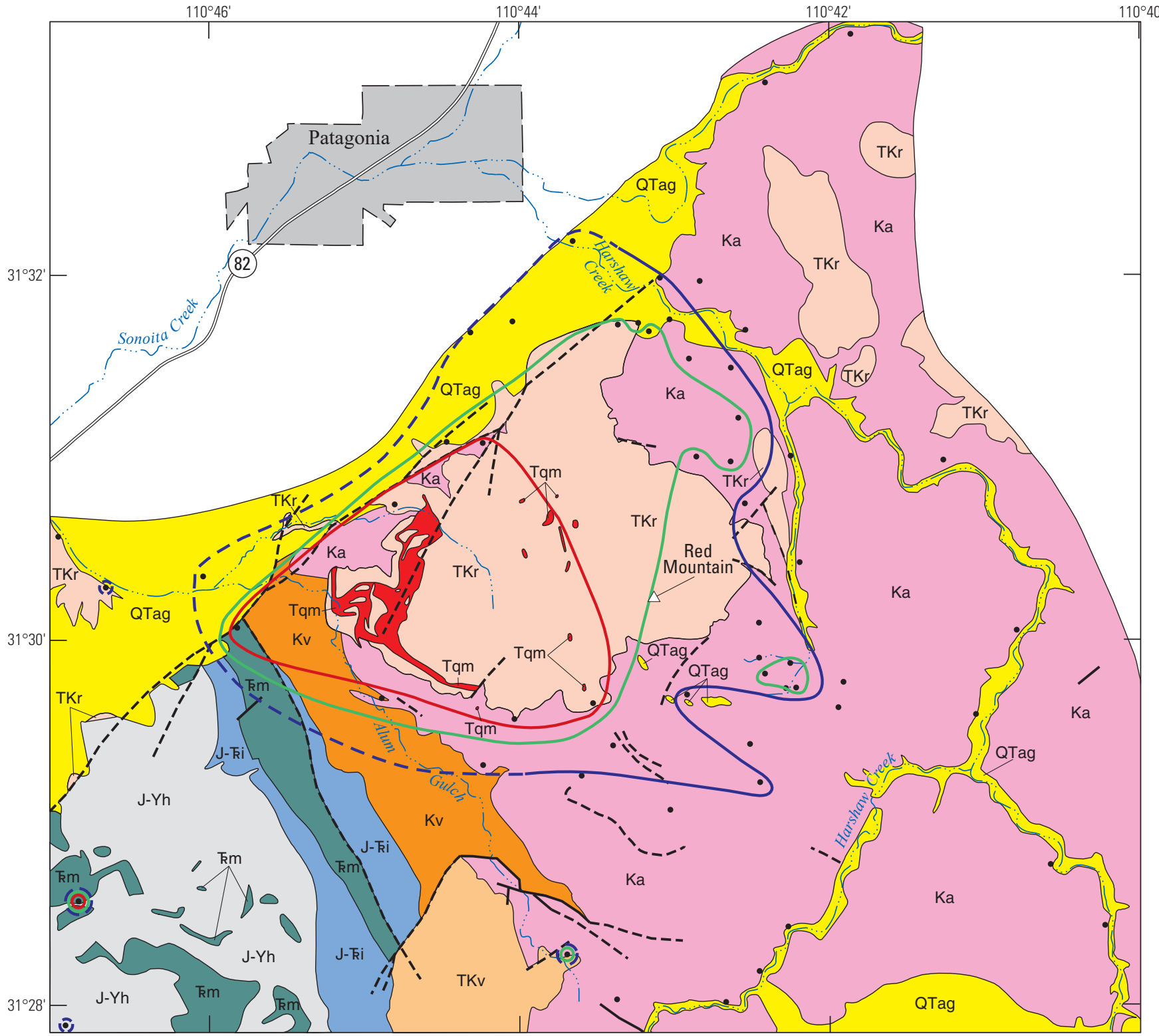

Figure 87. Distribution of silver in mesquite ash.

\section{EXPLANATION}

QTag Alluvium and terrace gravels, undivided

Quartz monzonite porphyryIntrusive rocks

TKr Volcanics of Red Mountain-Chiefly rhyolite tuff. Drewes, 1971a; 1972

TKv Felsic volcanic rocks-Chiefly latite

$\mathrm{Ka}$ Trachyandesite of Meadow ValleyChiefly andesite porphyry. Simons, 1972

Kv Silicic volcanics-Simons, 1974

$\mathrm{J}-\mathrm{Ki}$ Plutonic and volcanic rocks, undivided

Mount Wrightson Formation-Chiefly felsic volcanics

$\mathrm{J}-\mathrm{Yh}$ Hornblende-rich metamorphic and igneous rocks, undivided Contact-Locally concealed or inferred

Fault-Dashed where approximate or inferred

Distribution of silver in mesquite ash, in parts per million-Contours are shown with a solid line where the sample density is high. Where sample density is

$\begin{array}{r}-1.0 \\ \hline\end{array} 0.5$

$\longrightarrow \begin{array}{ll}0.5 \\ 0.3\end{array}$

- Sample site

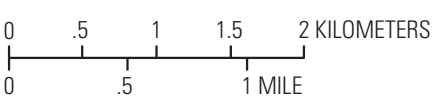

Base from U.S. Geological Survey digital data, 1:1,000,000, 2018 Geographic projection, decimal degrees

North American Datum of 1927

Geology modified from Drewes (1971a), Quinlan (1981, 1986) and Simons (1974). 




\section{EXPLANATION}

QTag Alluvium and terrace gravels undivided

Quartz monzonite porphyryIntrusive rocks

TKr Volcanics of Red Mountain - Chiefly rhyolite tuff. Drewes, 1971a; 1972

TKv Felsic volcanic rocks-Chiefly latite

$\mathrm{Ka}$ Trachyandesite of Meadow ValleyChiefly andesite porphyry.

$$
\text { Simons, } 1972
$$

Kv Silicic volcanics_Simons, 1974

J-下i Plutonic and volcanic rocks, undivided

Mount Wrightson Formation-Chiefly felsic volcanics

$\mathrm{J}-\mathrm{Yh}$ Hornblende-rich metamorphic and

$$
\text { igneous rocks, undivided }
$$

Contact-Locally concealed or

$$
\text { inferred }
$$

_ Fault-Dashed where approximate or inferred

Distribution of silver in oak ash, in parts per million-Contours are shown with a solid line where the sample density is high. Where sample density is low, the contours re dashed

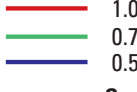

- Sample site

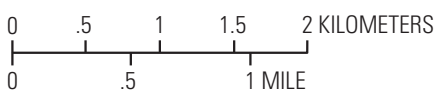

Base from U.S. Geological Survey digital data, 1:1,000,000, 2018 Geographic projection, decimal degrees North American Datum of 1927

Figure 88. Distribution of silver in oak ash. 


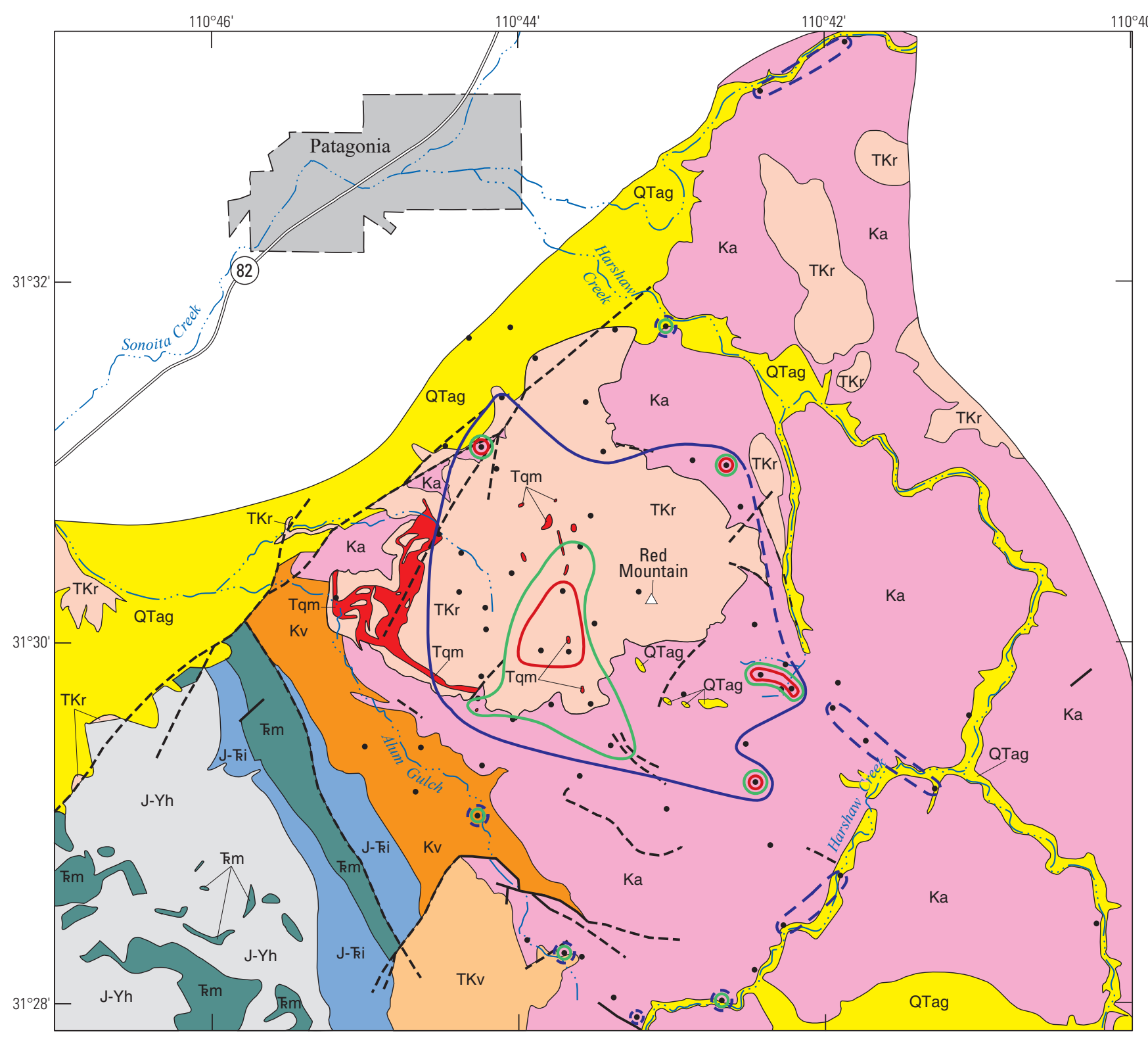

Figure 89. Distribution of silver in juniper ash.

\section{EXPLANATION}

QTag Alluvium and terrace gravels, undivided

Quartz monzonite porphyryIntrusive rocks

TKr Volcanics of Red Mountain-Chiefly rhyolite tuff. Drewes, 1971a; 1972

TKv Felsic volcanic rocks-Chiefly latite

$\mathrm{Ka}$ Trachyandesite of Meadow ValleyChiefly andesite porphyry. Simons, 1972

Kv Silicic volcanics-Simons, 1974

$\mathrm{J}-\mathrm{ki}$ Plutonic and volcanic rocks, undivided

Mount Wrightson Formation-Chiefly felsic volcanics

$\mathrm{J}-\mathrm{Yh}$ Hornblende-rich metamorphic and igneous rocks, undivided Contact-Locally concealed or inferred

Fault-Dashed where approximate or inferred

Distribution of silver in juniper ash, in parts per million-Contours are shown with per million-Contours are shown with
solid line where the sample density is high. Where sample density is low, the contours are dashed

\begin{tabular}{r}
9.0 \\
\hline \\
7.0 \\
5.0
\end{tabular}

- Sample site

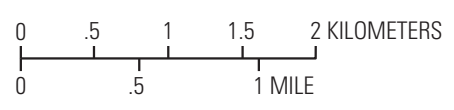

Base from U.S. Geological Survey digital data, 1:1,000,000, 2018 Geographic projection, decimal degrees

North American Datum of 1927

Geology modified from Drewes (1971a), Quinlan (1981, 1986), and Simons (1974). 
indicating that all three species are taking up most of these elements to some degree in response to the concentrations in the substrate soils. Armienta and others (2008) note that, in spite of the potential toxicity of arsenic, mesquite is arsenic tolerant and can accumulate considerable amounts in both leaves and stems. This tolerance for arsenic seems to be present for oak and juniper trees as well.

The median values for arsenic are 1.7, 5.0, and $5.3 \mathrm{ppm}$ for mesquite, oak, and juniper ash, respectively; for antimony are $0.12,0.18$, and $0.22 \mathrm{ppm}$, respectively; and for bismuth are $0.074,0.159$, and $0.106 \mathrm{ppm}$, respectively (tables 6-8). The distributions of arsenic, antimony, and bismuth in mesquite ash are shown on figures 90-92. Those for arsenic and bismuth exhibit high concentrations that are associated mostly with the rhyolite tuff unit (figs. 90 and 92). The distributions of antimony in mesquite ash (fig. 91) do not match those of the other two elements and probably do not reflect any meaningful anomalies. The distributions of high concentrations of all three elements in oak ash are generally highest over the western area containing the main outcrops of quartz monzonite porphyry (figs. 93, 94, and 95, respectively). In contrast, the distributions of all three elements in juniper ash (figs. 96, 97, and 98, respectively) are similar to those of copper and silver (figs. 83 and 89) and are centered farther to the east, over the cluster of small quartz monzonite porphyry outcrops. The distributions of antimony in all three species also exhibit anomalies near washes that probably are related to contamination from past mining.

Lead.-Lead is toxic when present in relatively high concentrations and is nonessential for plants (Levinson, 1974). The corresponding ash/soil ratio values for the three plant species reflect that, with low values ranging from 0.04 to 0.12 (tables 6-8). However, concentration ranges show that lead has been highly concentrated, especially in oak ash, which indicates a high tolerance for lead for that species.

The median values for lead in mesquite, oak, and juniper samples are 4.6, 13, and $6.6 \mathrm{ppm}$, respectively (tables 6-8). Lead is present in much lower concentrations in the mesquite ash (fig. 99) than in the ash of oak or juniper (figs. 100 and 101, respectively). That fact, plus the lack of sufficient sample sites over the deposit, explains why the distributions of high concentrations of lead in mesquite ash do not show meaningful anomalies related to the hypogene $\mathrm{Cu}-\mathrm{Mo}$ deposit. High concentrations of lead in oak and juniper ash show patterns that are similar to those of lead in soil (fig. 59). Anomalous lead concentrations for these two species are approximately centered over the cluster of quartz monzonite porphyry outcrops in the middle of the rhyolite tuff unit. Concentrations exceeding $100 \mathrm{ppm}$ lead in oak ash samples are more common than those for juniper, probably because of the relatively higher overall concentrations of lead in oak ash as reflected in the median values. Anomalous lead that is a result of contamination from past mining is present in major drainages for all three species.

Zinc and Cadmium.-These two elements commonly occur together in many natural substances. In low concentrations, zinc is considered essential for plants and cadmium may also be essential (Brooks, 1983; Shacklette, 1972). Both zinc and cadmium exhibit high ash/soil ratios for all three species (tables 6-8). In particular, the ratio value for zinc in mesquite ash samples (5.0) and for cadmium in the oak ash samples (47) are unusually high. These two high ratio values indicate that mesquite trees in the environment at Red Mountain have a higher accumulation rate and tolerance for zinc, and oak trees have a high accumulation rate and tolerance for potentially toxic cadmium.

The median values for zinc are 511, 226, and $202 \mathrm{ppm}$ for mesquite, oak, and juniper ash, respectively; and for cadmium are $0.54,11.75$, and $1.03 \mathrm{ppm}$, respectively (tables $6-8$ ). The distributions of zinc and cadmium in the three species are shown on figures 102-107. Concentrations in the mesquite ash show positive anomalies for both elements that are centered over the general area of the deposit (figs. 102 and 103 , respectively). Positive anomalies of zinc and cadmium occur in oak ash in the area of the main quartz monzonite porphyry outcrop (figs. 104 and 105, respectively). Zinc in juniper ash exhibits a positive anomaly that is mostly concentrated over the northwestern part of the rhyolite tuff unit and includes the two main areas of quartz monzonite porphyry (fig. 106). In contrast, cadmium in juniper ash exhibits a negative anomaly over this same area as well as over a wide area to the southeast (fig. 107).

Selenium.-This element is essential in many plant species but may not be essential for all species (Brooks, 1983). Ash/soil ratios could not be calculated for any of the plant species because selenium was not determined in most rock or soil samples. The median values for selenium are $1.10,0.89$, and $1.06 \mathrm{ppm}$ for mesquite, oak, and juniper ash, respectively (tables 6-8). Because of the lack of sample sites, the distribution of selenium in mesquite ash is not meaningful in terms of delineating anomalies related to the hypogene $\mathrm{Cu}-\mathrm{Mo}$ deposit. The only significant selenium anomaly in mesquite ash is located southeast of the main surface exposures of the deep copper deposit, in a mostly altered area in the andesite unit (fig. 108). The highest concentrations of selenium in oak ash are centered over the area of the rhyolite tuff unit and especially over the main quartz monzonite porphyry outcrop (fig. 109). In contrast, the distribution of high selenium concentrations in juniper ash is more widespread and encompasses the rhyolite tuff unit and also adjacent parts of the andesite unit, mainly to the south of the rhyolite tuff unit (fig. 110). 


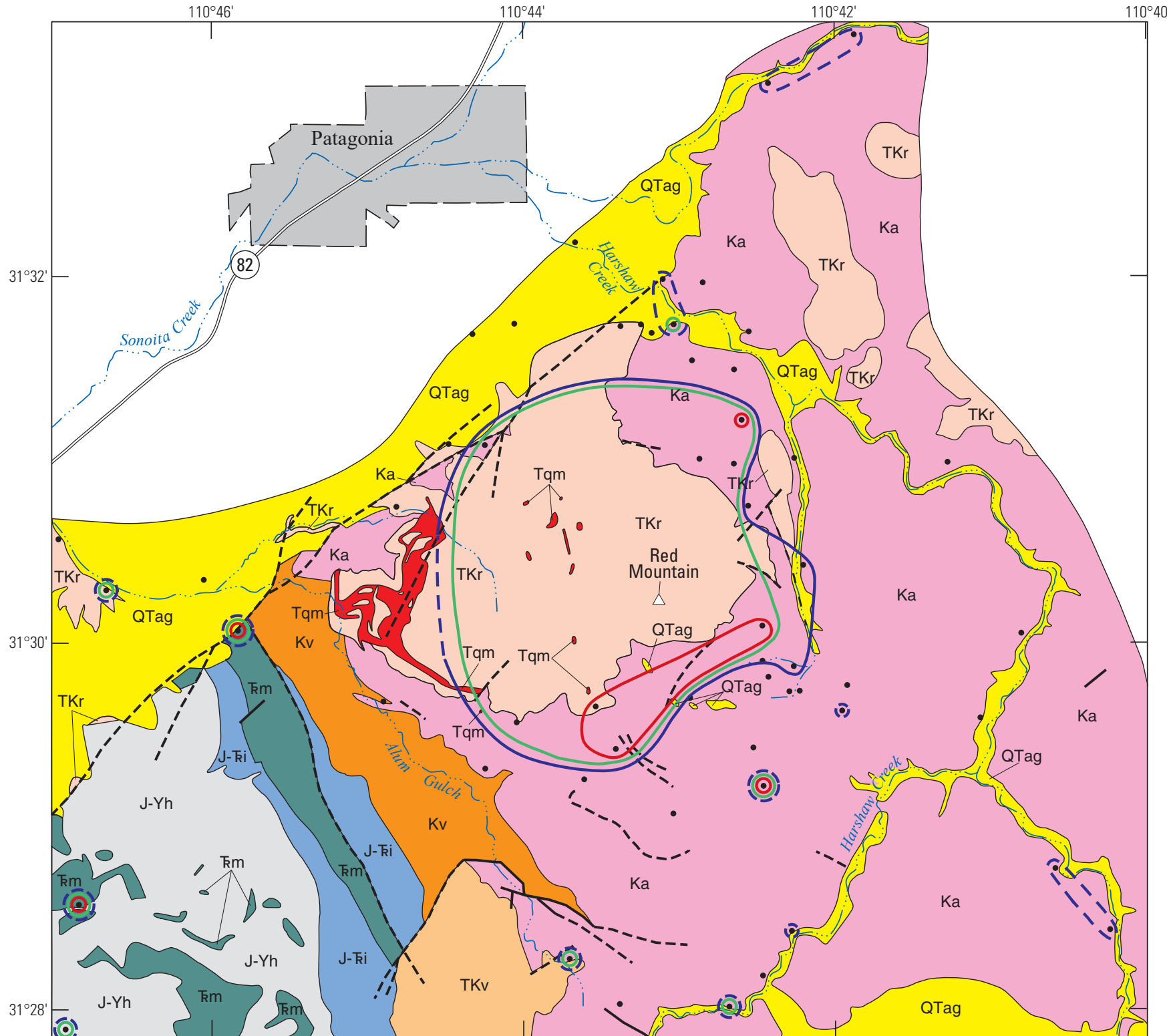

Figure 90. Distribution of arsenic in mesquite ash.

\section{EXPLANATION}

QTag Alluvium and terrace gravels, undivided

Quartz monzonite porphyryIntrusive rocks

TKr Volcanics of Red Mountain - Chiefly rhyolite tuff. Drewes, 1971a; 1972

TKv Felsic volcanic rocks-Chiefly latite

Ka Trachyandesite of Meadow ValleyChiefly andesite porphyry. Simons, 1972

Kv Silicic volcanics-Simons, 1974

$\mathrm{J}-\mathrm{ki}$ Plutonic and volcanic rocks, undivided

Mount Wrightson Formation-Chiefly felsic volcanics

$\mathrm{J}-\mathrm{Yh}$ Hornblende-rich metamorphic and igneous rocks, undivide Contact-Locally concealed or inferred

Fault-Dashed where approximate or inferred

Distribution of arsenic in mesquite ash, in parts per million-Contours are shown parts per million-Contours are she
with a solid line where the sample density is high. Where sample density is

\begin{tabular}{ll}
$\square$ & 4 \\
\hline & 2
\end{tabular}

- $\quad$ Sample site

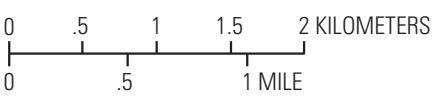

Base from U.S. Geological Survey digital data, 1:1,000,000, 2018 Geographic projection, decimal degrees

North American Datum of 1927

Geology modified from Drewes (1971a), Quinlan (1981, 1986) and Simons (1974). 




\section{EXPLANATION}

QTag Alluvium and terrace gravels, undivided

Ouartz monzonite porphyryIntrusive rocks

TKr Volcanics of Red Mountain-Chiefly rhyolite tuff. Drewes, 1971a; 1972

TKv Felsic volcanic rocks-Chiefly latite

$\mathrm{Ka}$ Trachyandesite of Meadow ValleyChiefly andesite porphyry.$$
\text { Simons, } 1972
$$

Kv Silicic volcanics-Simons, 1974

J-ki Plutonic and volcanic rocks, undivided

Mount Wrightson Formation-Chiefly felsic volcanics

$\mathrm{J}-\mathrm{Yh}$ Hornblende-rich metamorphic and

$$
\text { igneous rocks, undivided }
$$

Contact-Locally concealed or

$$
\text { inferred }
$$

— Fault-Dashed where approximate or inferred

Distribution of antimony in mesquite ash, in parts per million-Contours are shown with a solid line where the sample density is high. Where sample density is low, the contours are dashed

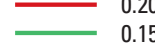

$\longrightarrow \begin{array}{r}0.15 \\ 0.10\end{array}$

- Sample site

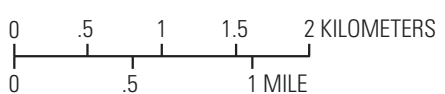

Base from U.S. Geological Survey digital data, 1:1,000,000, 2018 Geographic projection, decimal degrees North American Datum of 1927

Figure 91. Distribution of antimony in mesquite ash. 


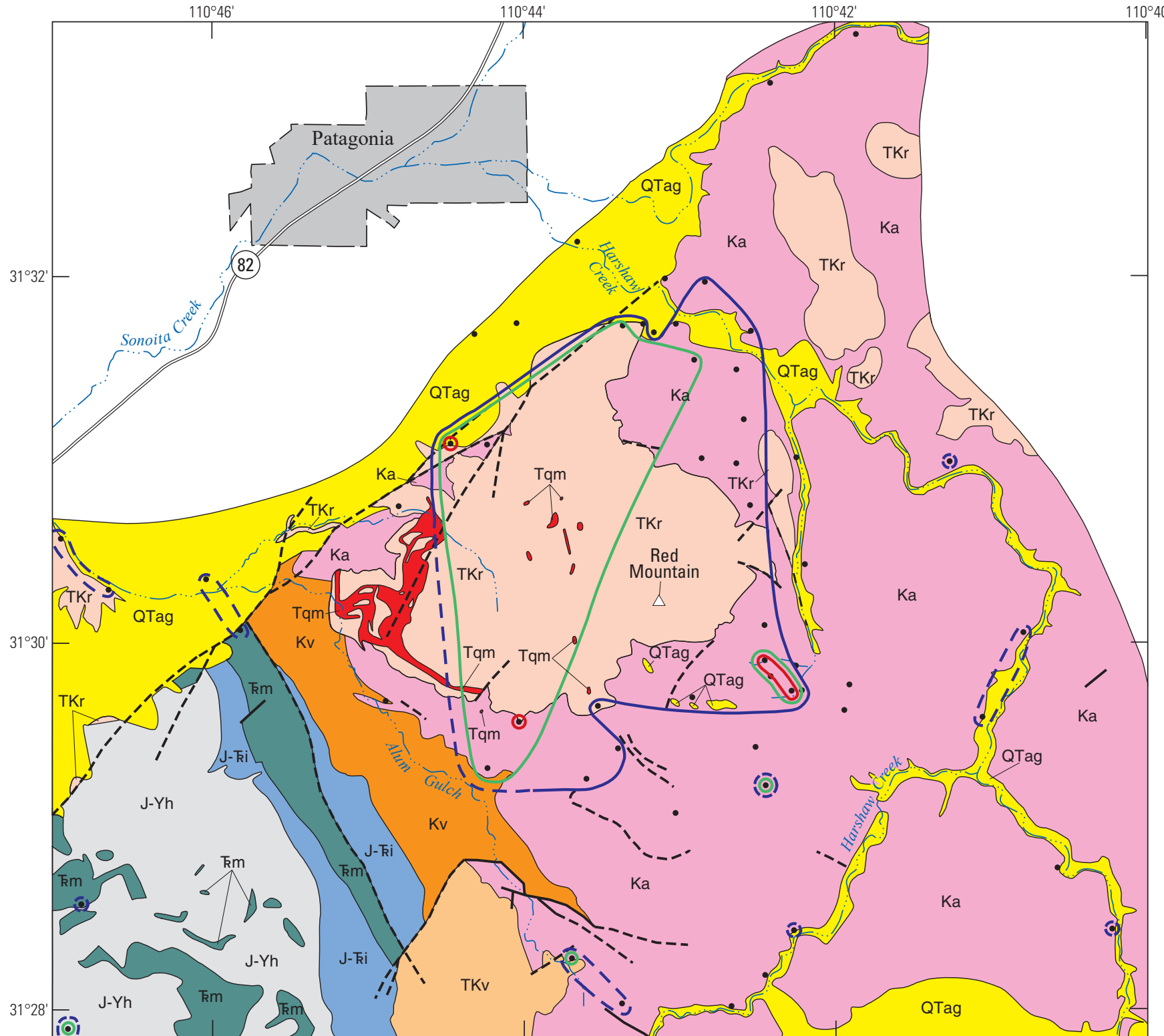

Figure 92. Distribution of bismuth in mesquite ash.

\section{EXPLANATION}

QTag Alluvium and terrace gravels, undivided

Quartz monzonite porphyryIntrusive rocks

TKr Volcanics of Red Mountain—Chiefly rhyolite tuff. Drewes, 1971a; 1972

TKv Felsic volcanic rocks-Chiefly latite

Ka Trachyandesite of Meadow ValleyChiefly andesite porphyry. Simons, 1972

Kv Silicic volcanics-Simons, 1974

$\mathrm{J}$ - $\mathrm{Ki}$ Plutonic and volcanic rocks, undivided

Mount Wrightson Formation-Chiefly felsic volcanics

$\mathrm{J}-\mathrm{Yh}$ Hornblende-rich metamorphic and igneous rocks, undivide Contact-Locally concealed or inferred

Fault-Dashed where approximate or inferred

Distribution of bismuth in mesquite ash, in parts per million-Contours are shown parts per million-Contours are she
with a solid line where the sample density is high. Where sample density is low, the contours are dashed

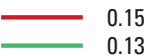

0.13
0.07

- Sample site

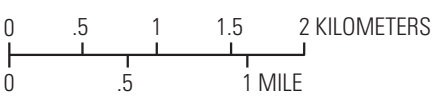

Base from U.S. Geological Survey digital data, 1:1,000,000, 2018 Geographic projection, decimal degrees

North American Datum of 1927

Geology modified from Drewes (1971a), Quinlan (1981, 1986) and Simons (1974). 


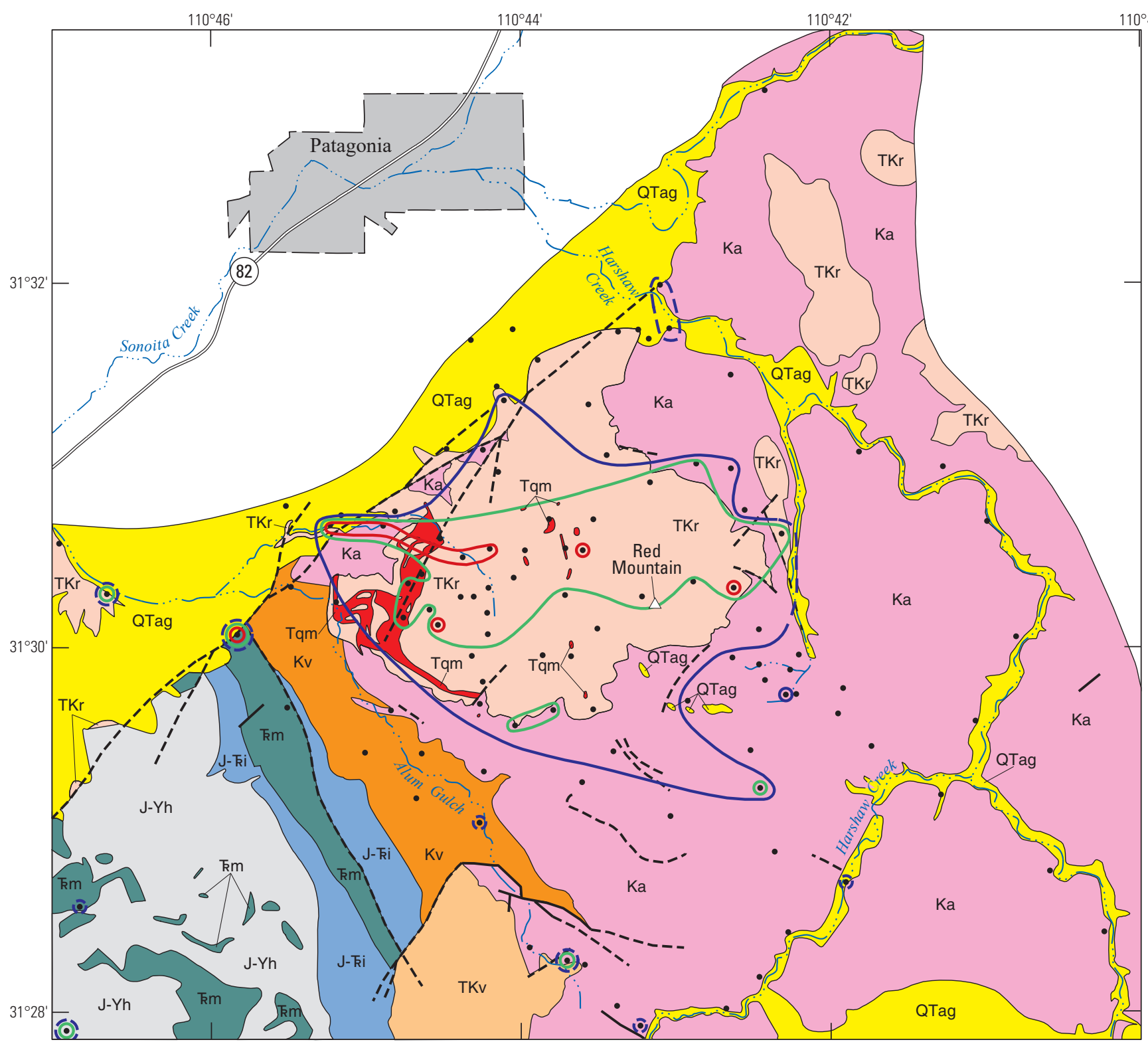

QTag Alluvium and terrace gravels, undivided

Quartz monzonite porphyryIntrusive rocks

\begin{tabular}{|l|l}
\hline$T K r$ & Volcanics of Red Mountain-Chiefly \\
\hline
\end{tabular} rhyolite tuff. Drewes, $1971 \mathrm{a} ; 1972$

TKV Felsic volcanic rocks-Chiefly latite

Ka Trachyandesite of Meadow ValleyChiefly andesite porphyry. Simons, 1972

KV Silicic volcanics-Simons, 1974

J-ki Plutonic and volcanic rocks, undivided

Mount Wrightson Formation-Chiefly felsic volcanics

$\mathrm{J}-\mathrm{Yh}$ Hornblende-rich metamorphic and igneous rocks, undivided Contact-Locally concealed or

inferred
Fault-Dashed where approximate or inferred

Distribution of arsenic in oak ash, in parts per million-Contours are shown with a solid line where the sample density is high. Where sample density is low, the contours are dashed

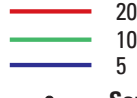
20
10

- $\quad$ Sample site

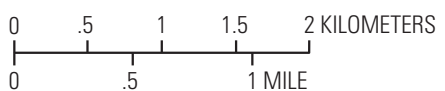

Base from U.S. Geological Survey digital data, 1:1,000,000, 2018 Geographic projection, decimal degrees North American Datum of 1927

Figure 93. Distribution of arsenic in oak ash. 


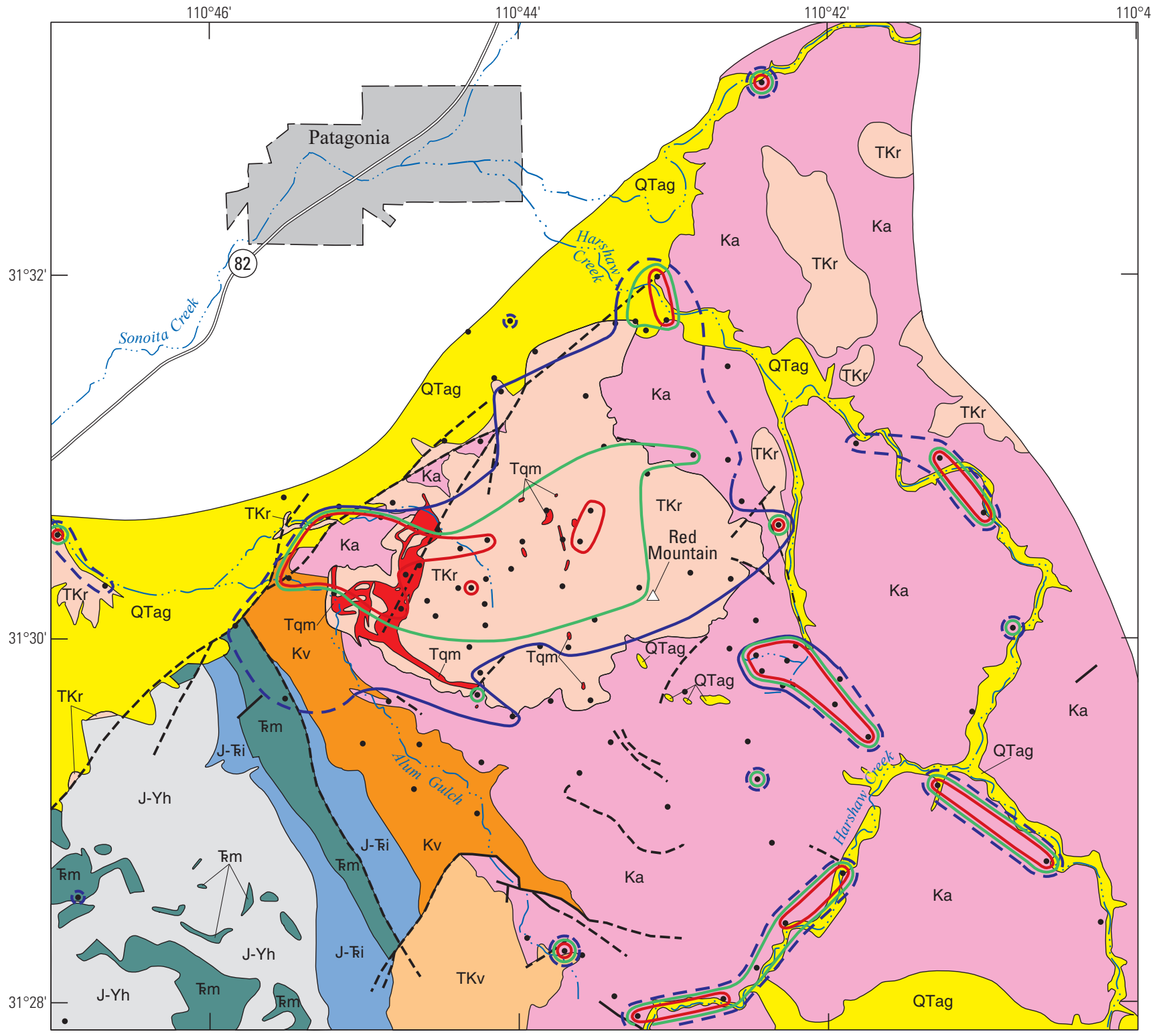

Figure 94. Distribution of antimony in oak ash.

\section{EXPLANATION}

QTag Alluvium and terrace gravels, undivided

Quartz monzonite porphyry-

Intrusive rocks

TKr Volcanics of Red Mountain-Chiefly rhyolite tuff. Drewes, 1971a; 1972

TKv Felsic volcanic rocks-Chiefly latite

\begin{tabular}{|l|}
\hline Ka \\
\hline
\end{tabular} Chiefly andesite porphyry. Simons, 1972

Kv Silicic volcanics-Simons, 1974

$\mathrm{J}-\mathrm{ki}$ Plutonic and volcanic rocks, undivided

$\mathrm{km}$ Mount Wrightson Formation-Chiefly felsic volcanics

$\mathrm{J}-\mathrm{Yh}$ Hornblende-rich metamorphic and igneous rocks, undivided Contact-Locally concealed or inferred

_ Fault—Dashed where approximat or inferred

Distribution of antimony in oak ash, in parts per million-Contours are shown with a solid line where the sample density is high. Where sample density is low, the contours are dashed

0.25
0.20
0.15

0.20
-15

- Sample site

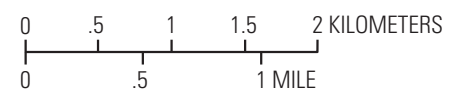

Base from U.S. Geological Survey digital data, 1:1,000,000, 2018 Geographic projection, decimal degrees North American Datum of 1927

Geology modified from Drewes (1971a), Quinlan (1981, 1986), and Simons (1974). 


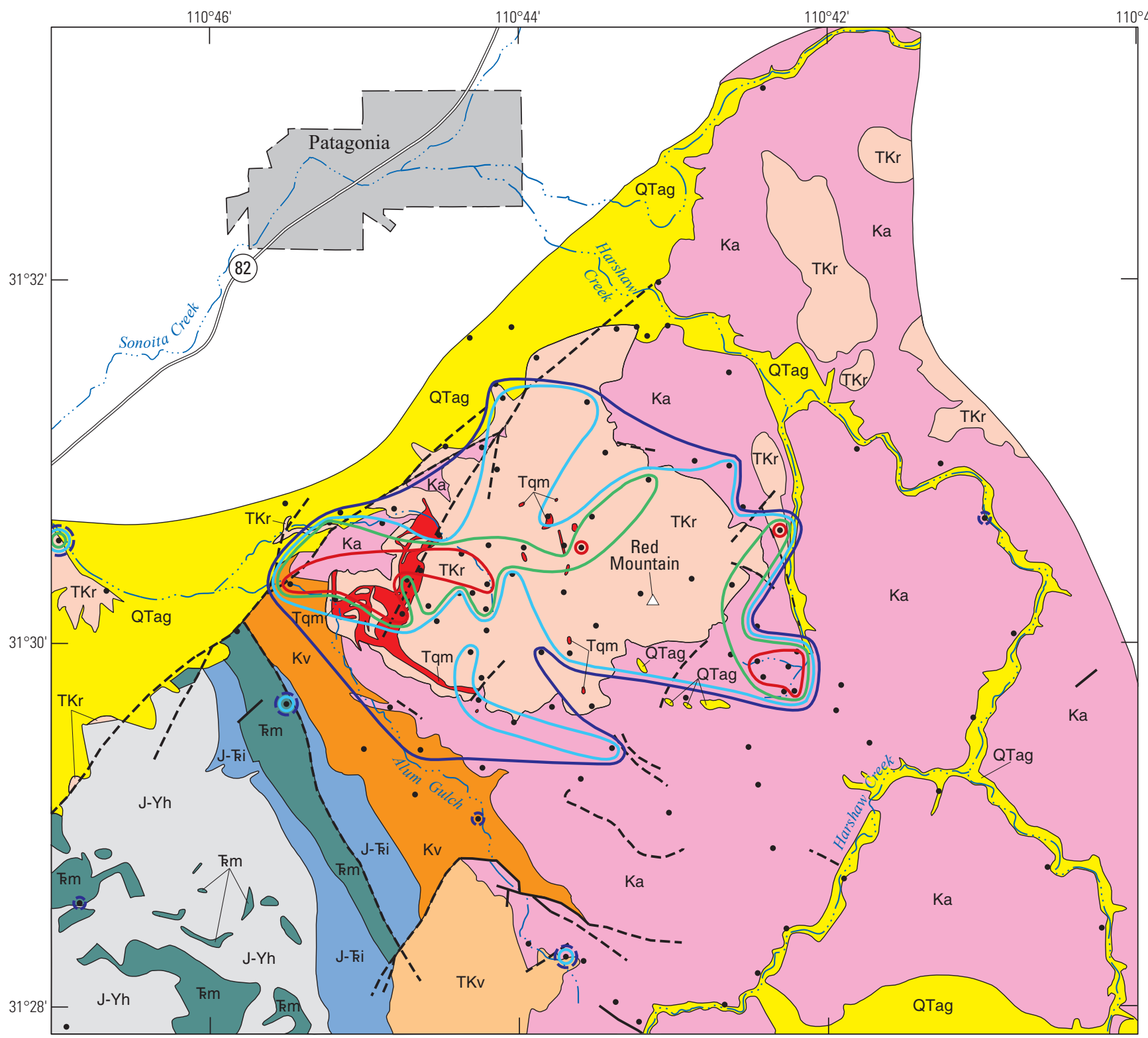

\section{EXPLANATION}

QTag Alluvium and terrace gravels, undivided

Quartz monzonite porphyryIntrusive rocks

TKr Volcanics of Red Mountain - Chiefly rhyolite tuff. Drewes, 1971a; 1972

TKv Felsic volcanic rocks-Chiefly latite

Ka Trachyandesite of Meadow ValleyChiefly andesite porphyry. Simons, 1972

Kv Silicic volcanics-Simons, 1974

J-ki Plutonic and volcanic rocks, undivided

Mount Wrightson Formation-Chiefly felsic volcanics

$\mathrm{J}-\mathrm{Yh}$ Hornblende-rich metamorphic and

$$
\text { igneous rocks, undivided }
$$

inferred
Fault-Dashed where approximate or inferred

Distribution of bismuth in oak ash, in parts per million-Contours are shown with a solid line where the sample density is high. Where sample density is low, the contours are dashed

$\begin{array}{r}0.30 \\ - \\ \hline\end{array}$

0.25
0.20

$-\quad 0.15$

- Sample site

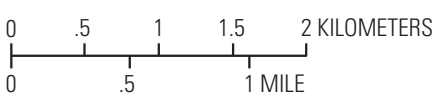

Base from U.S. Geological Survey digital data, 1:1,000,000, 2018 Geographic projection, decimal degrees North American Datum of 1927 and Simons (1974).

Figure 95. Distribution of bismuth in oak ash. 


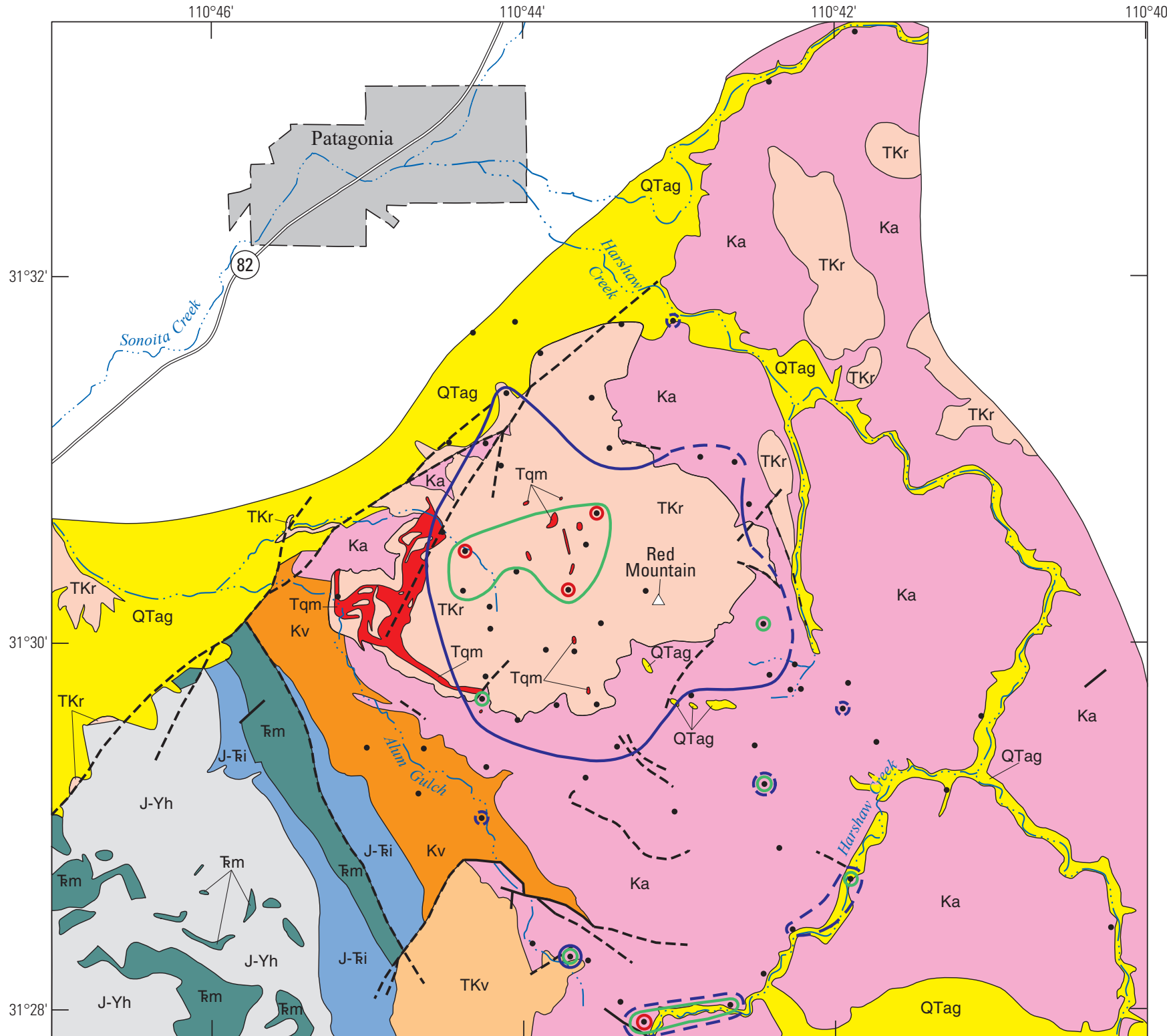

Figure 96. Distribution of arsenic in juniper ash.

\section{EXPLANATION}

QTag Alluvium and terrace gravels, undivided

Quartz monzonite porphyryIntrusive rocks

TKr Volcanics of Red Mountain-Chiefly rhyolite tuff. Drewes, 1971a; 1972

TKv Felsic volcanic rocks-Chiefly latite

$\mathrm{Ka}$ Trachyandesite of Meadow ValleyChiefly andesite porphyry. Simons, 1972

Kv Silicic volcanics-Simons, 1974

$\mathrm{J}-\mathrm{Ki}$ Plutonic and volcanic rocks, undivided

Mount Wrightson Formation-Chiefly felsic volcanics

J-Yh Hornblende-rich metamorphic and igneous rocks, undivided Contact-Locally concealed or inferred

Fault-Dashed where approximate or inferred

Distribution of arsenic in juniper ash, in parts per million-Contours are shown with solid line where the sample density is high. Where sample density is low, the contours are dashed

\begin{tabular}{ll}
$\square$ & 15 \\
$\square$ & 10 \\
\hline & 5
\end{tabular} contours are dashed

- Sample site

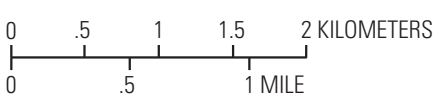

Base from U.S. Geological Survey digital data, 1:1,000,000, 2018 Geographic projection, decimal degrees North American Datum of 1927

Geology modified from Drewes (1971a), Quinlan (1981, 1986) and Simons (1974). 


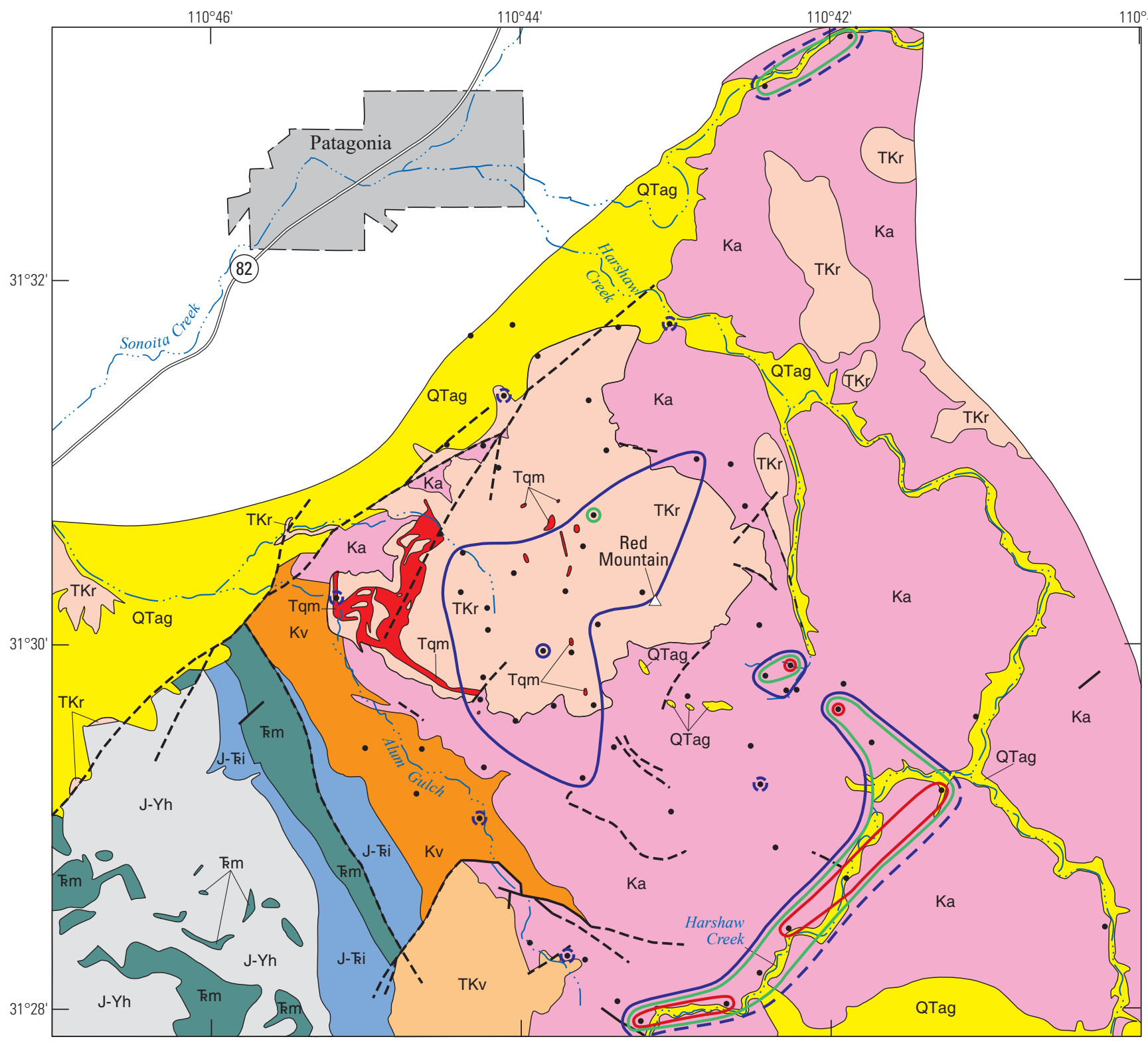

QTag Alluvium and terrace gravels,

$$
\text { undivided }
$$

Quartz monzonite porphyryIntrusive rocks

TKr Volcanics of Red Mountain-Chiefly rhyolite tuff. Drewes, 1971a; 1972

TKv Felsic volcanic rocks-Chiefly latite

Ka Trachyandesite of Meadow ValleyChiefly andesite porphyry. Simons, 1972

Kv Silicic volcanics-Simons, 1974

$\mathrm{J}-\mathrm{ki}$ Plutonic and volcanic rocks, undivided

Mount Wrightson Formation-Chiefly felsic volcanics

$\mathrm{J}-\mathrm{Yh}$ Hornblende-rich metamorphic and

$$
\text { igneous rocks, undivided }
$$

Contact-Locally concealed or inferred

- Fault-Dashed where approximate or inferred

Distribution of antimony in juniper ash, in parts per million-Contours are shown with a solid line where the sample density is high. Where sample density is low, the contours are dashed

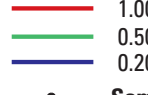

$$
0.50
$$

- Sample site

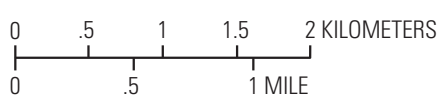

Base from U.S. Geological Survey digital data, 1:1,000,000, 2018 Geographic projection, decimal degrees North American Datum of 1927

Figure 97. Distribution of antimony in juniper ash. 


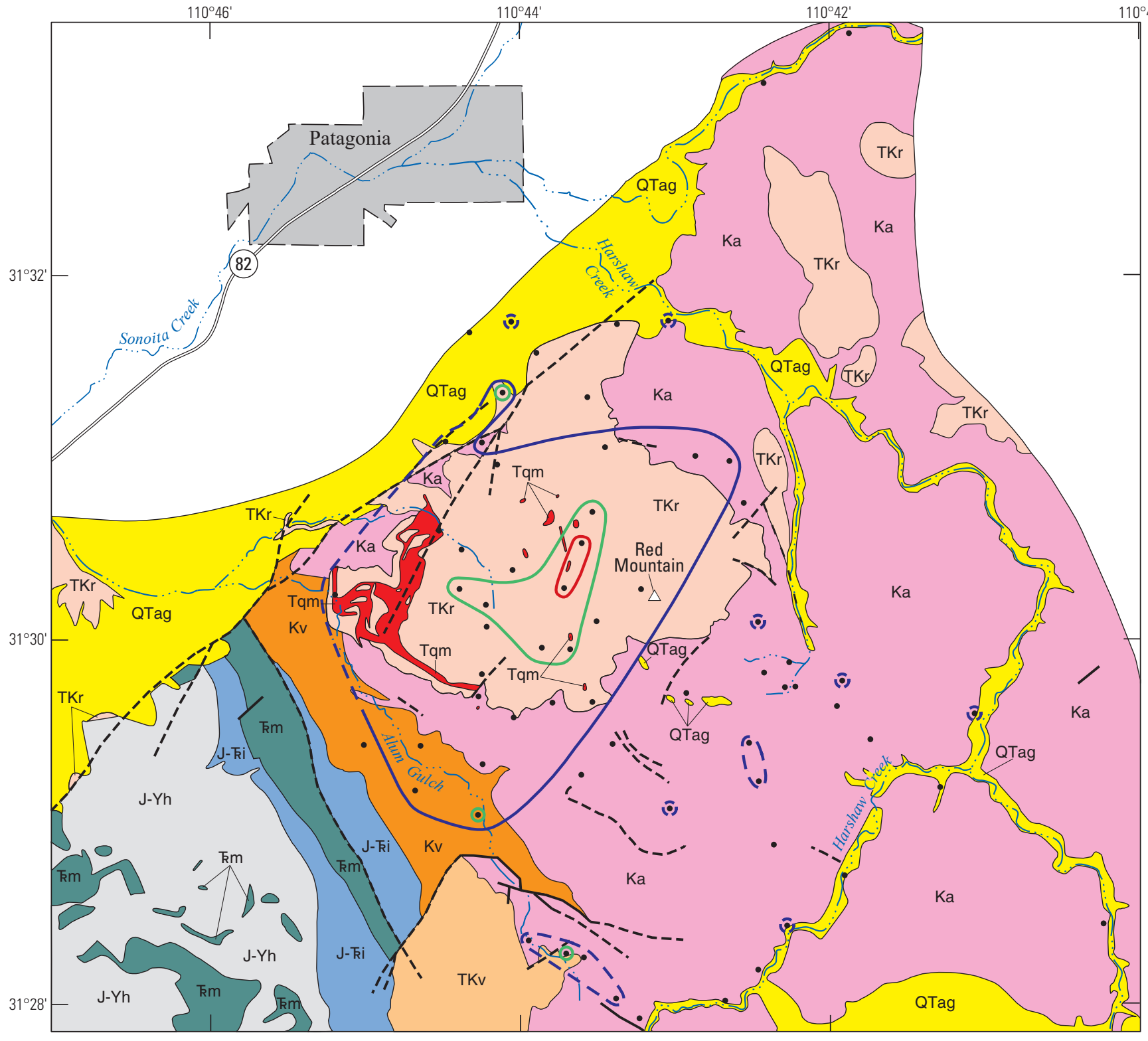

Figure 98. Distribution of bismuth in juniper ash

\section{EXPLANATION}

QTag Alluvium and terrace gravels undivided

Quartz monzonite porphyryIntrusive rocks

TKr Volcanics of Red Mountain-Chiefly rhyolite tuff. Drewes, 1971a; 1972

TKv Felsic volcanic rocks-Chiefly latite

$\mathrm{Ka}$ Trachyandesite of Meadow ValleyChiefly andesite porphyry. Simons, 1972

Kv Silicic volcanics-Simons, 1974

$\mathrm{J}$ - $\mathrm{ki}$ Plutonic and volcanic rocks, undivided

Mount Wrightson Formation-Chiefly felsic volcanics

$\mathrm{J}-\mathrm{Yh}$ Hornblende-rich metamorphic and igneous rocks, undivided Contact-Locally concealed or inferred

Fault-Dashed where approximate or inferred

Distribution of bismuth in juniper ash, in parts per million-Contours are shown with a solid line where the sample density is high. Where sample density is low, the contours are dashed

0.40
0.20

- Sample si

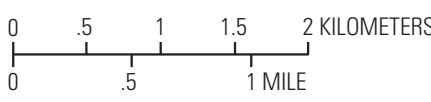

Base from U.S. Geological Survey digital data, 1:1,000,000, 2018 Geographic projection, decimal degrees

North American Datum of 1927

Geology modified from Drewes (1971a), Quinlan $(1981,1986)$ and Simons (1974). 


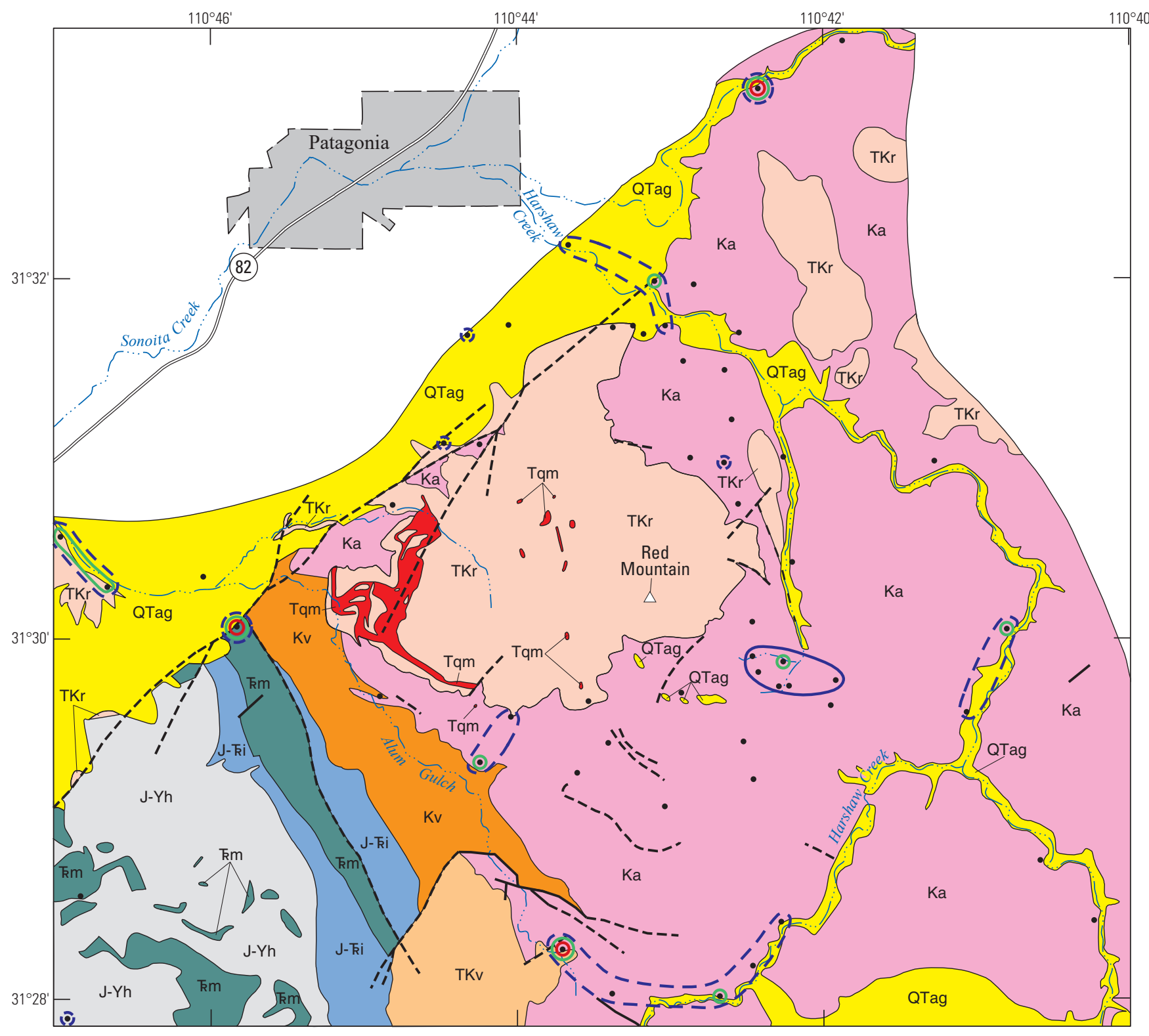

EXPLANATION QTag Alluvium and terrace gravels,
undivided

Quartz monzonite porphyryIntrusive rocks

TKr Volcanics of Red Mountain-Chiefly rhyolite tuff. Drewes, 1971a; 1972

TKv Felsic volcanic rocks-Chiefly latite

Ka Trachyandesite of Meadow ValleyChiefly andesite porphyry.

$$
\text { Simons, } 1972
$$

Kv Silicic volcanics-Simons, 1974

J-ki Plutonic and volcanic rocks, undivided

Mount Wrightson Formation-Chiefly felsic volcanics

$\mathrm{J}$-Yh Hornblende-rich metamorphic and

$$
\text { igneous rocks, undivided }
$$

Contact-Locally concealed or inferred

- Fault-Dashed where approximate or inferred

Distribution of lead in mesquite ash, in parts per million-Contours are shown with a solid line where the sample density is high. Where sample density is low, the contours are dashed

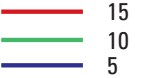

- Sample site

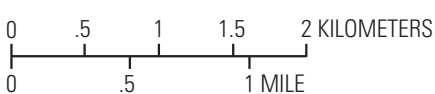

Base from U.S. Geological Survey digital data, 1:1,000,000, 2018 Geographic projection, decimal degrees North American Datum of 1927 and Simons (1974).

Figure 99. Distribution of lead in mesquite ash. 


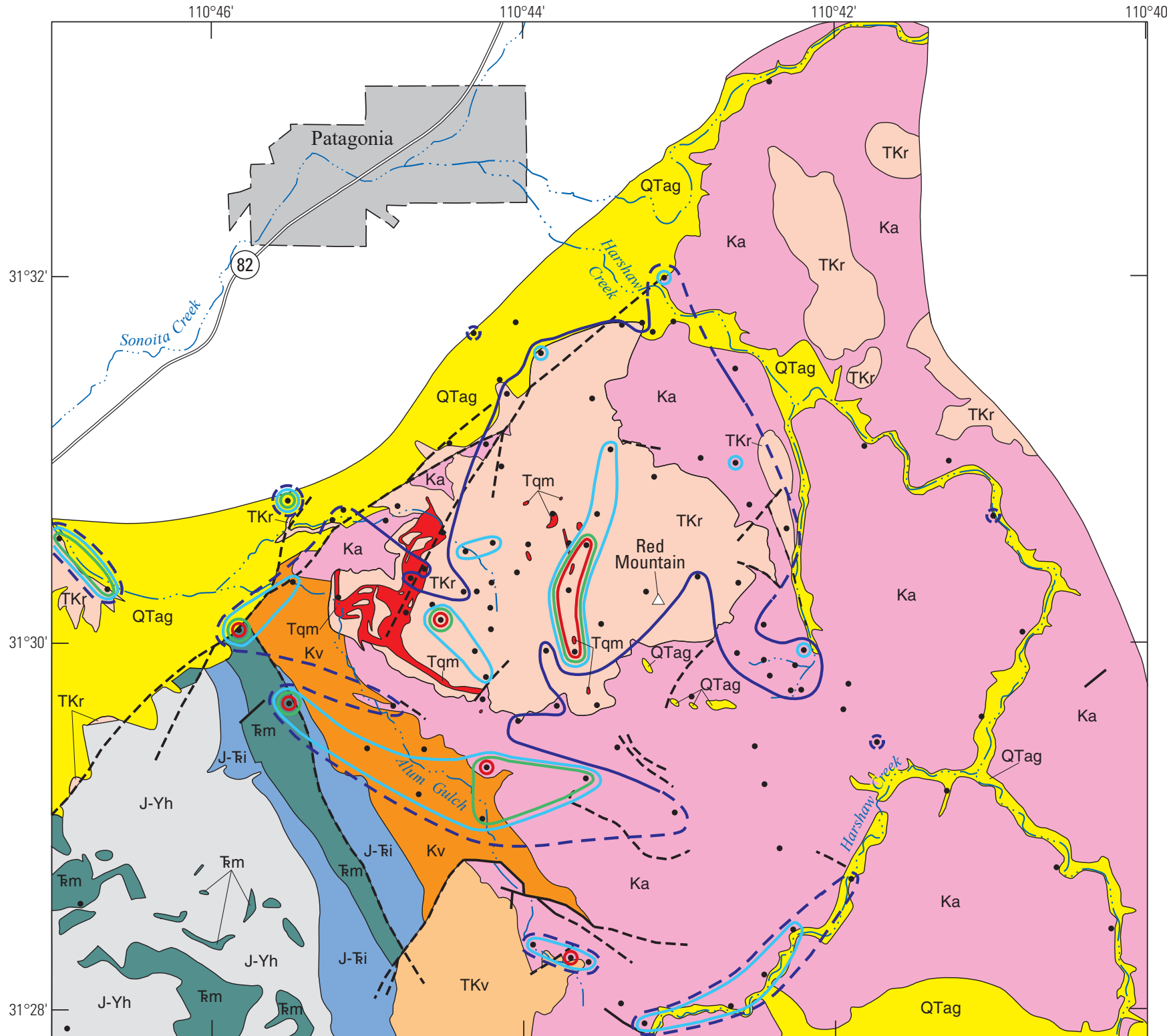

Figure 100. Distribution of lead in oak ash.

\section{EXPLANATION}

QTag Alluvium and terrace gravels undivided

Quartz monzonite porphyryIntrusive rocks

TKr Volcanics of Red Mountain-Chiefly rhyolite tuff. Drewes, 1971a; 1972

TKv Felsic volcanic rocks-Chiefly latite

$\mathrm{Ka}$ Trachyandesite of Meadow ValleyChiefly andesite porphyry. Simons, 1972

Silicic volcanics-Simons, 1974

Plutonic and volcanic rocks, undivided

Mount Wrightson Formation-Chiefly felsic volcanics

$\mathrm{J}-\mathrm{Yh}$ Hornblende-rich metamorphic and igneous rocks, undivided Contact-Locally concealed or

inferred
Fault-Dashed where approximate or inferred

Distribution of lead in oak ash, in parts per million-Contours are shown with a solid line where the sample density is high. Where sample density is low, the contours are dashed

\begin{tabular}{rr}
$\square$ & 100 \\
$\square$ & 50 \\
\hline & 20 \\
& 10
\end{tabular}

- Sample site

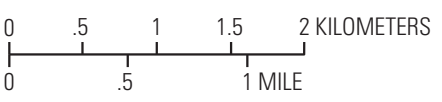

Base from U.S. Geological Survey digital data, 1:1,000,000, 2018 Geographic projection, decimal degrees

North American Datum of 1927

Geology modified from Drewes (1971a), Quinlan (1981, 1986$)$ and Simons (1974). 


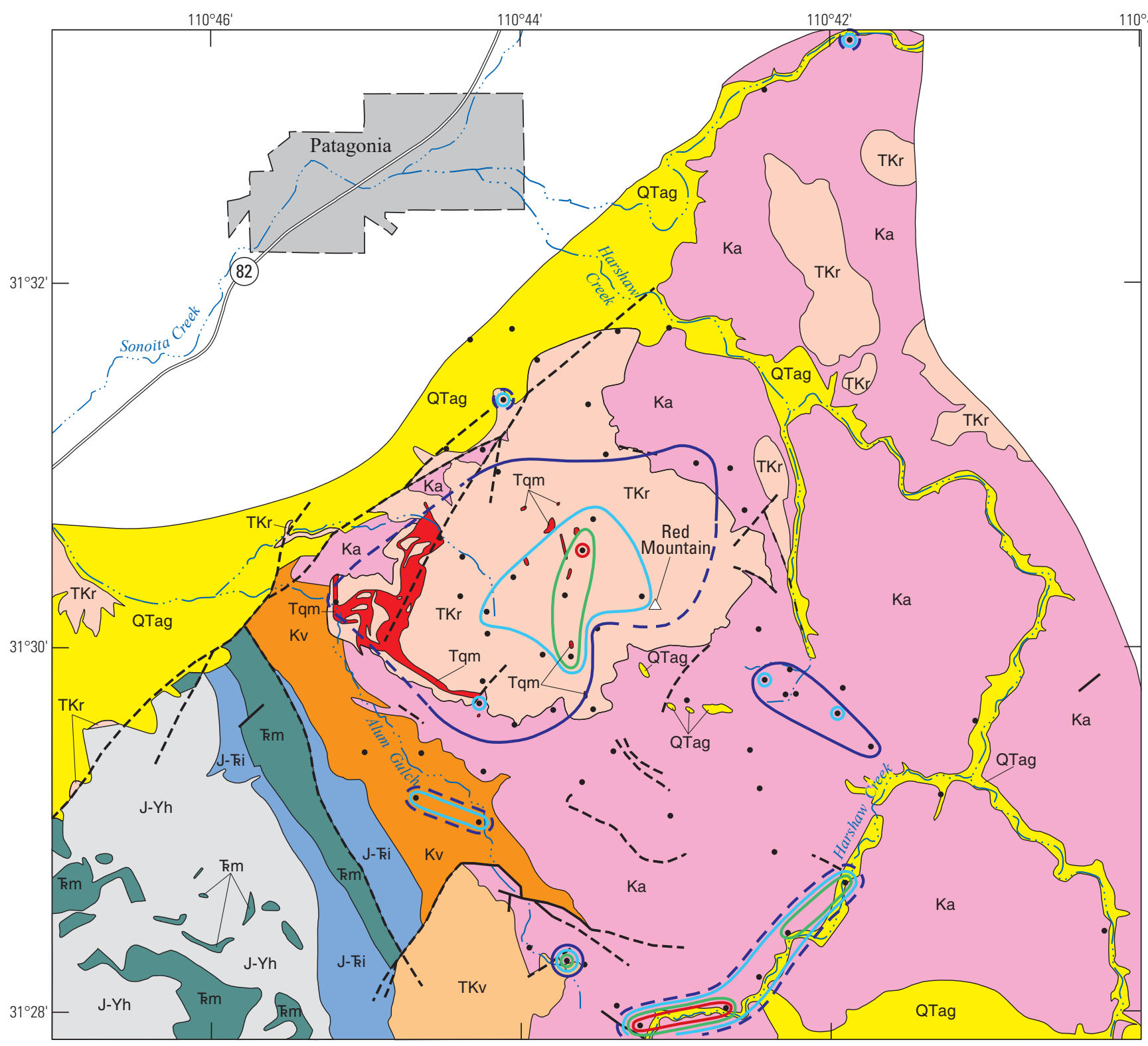

QTag Alluvium and terrace gravels,

$$
\text { undivided }
$$

Quartz monzonite porphyryIntrusive rocks

TKr Volcanics of Red Mountain - Chiefly rhyolite tuff. Drewes, 1971a; 1972

TKv Felsic volcanic rocks-Chiefly latite

Ka Trachyandesite of Meadow ValleyChiefly andesite porphyry. Simons, 1972

Kv Silicic volcanics-Simons, 1974

$\mathrm{J}-\mathrm{ki}$ Plutonic and volcanic rocks, undivided

Mount Wrightson Formation-Chiefly felsic volcanics

$\mathrm{J}-\mathrm{Yh}$ Hornblende-rich metamorphic and

$$
\text { igneous rocks, undivided }
$$

Contact-Locally concealed or inferred

_ Fault-Dashed where approximate or inferred

Distribution of lead in juniper ash, in parts per million-Contours are shown with solid line where the sample density is high. Where sample density is low, the

contours are dashed 50

\begin{tabular}{l}
$\square$ \\
$\square \quad 6$ \\
\hline
\end{tabular}

- Sample site

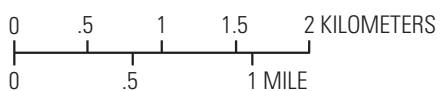

Base from U.S. Geological Survey digital data, 1:1,000,000, 2018 Geographic projection, decimal degrees North American Datum of 1927

Figure 101. Distribution of lead in juniper ash. 


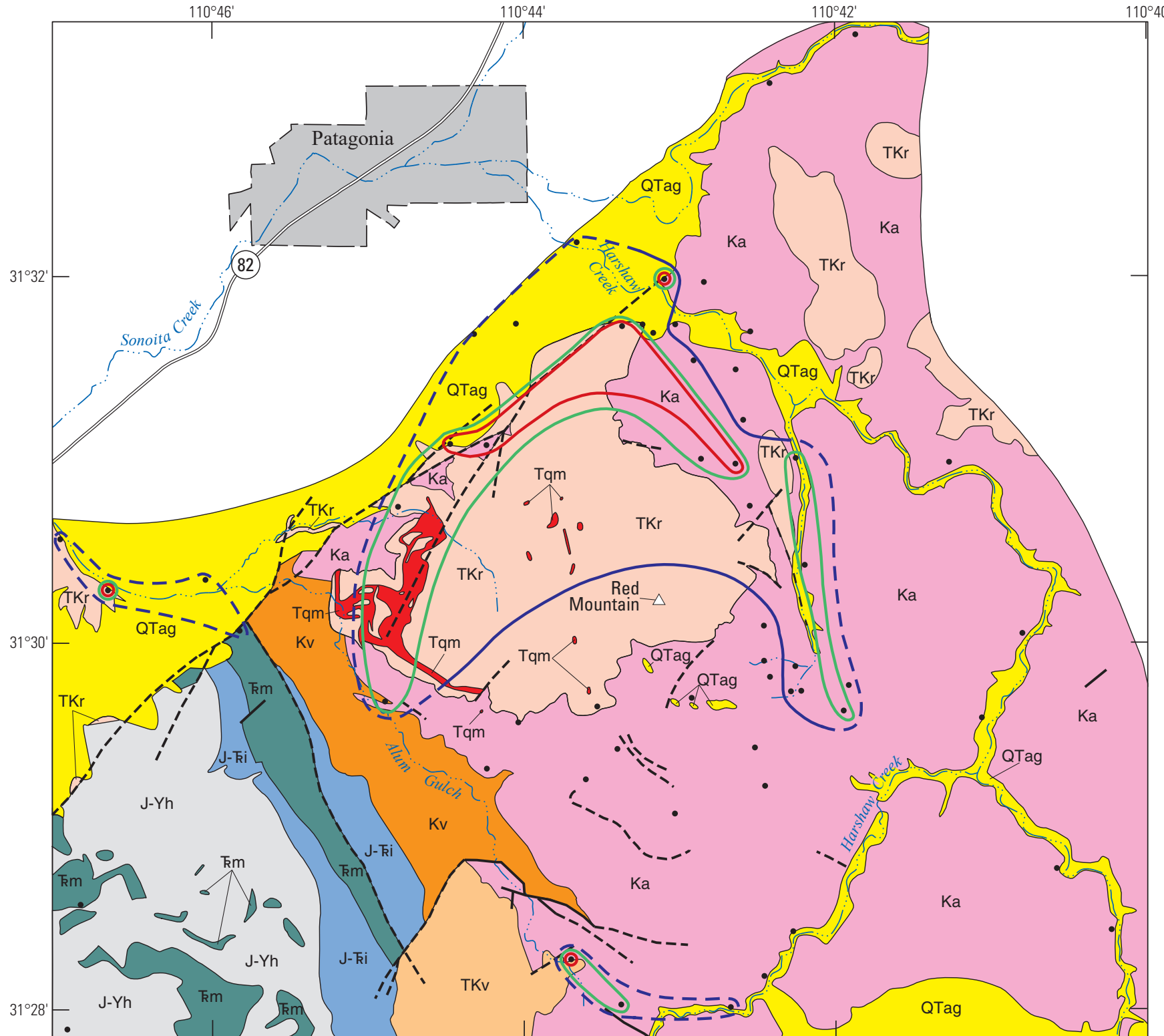

Figure 102. Distribution of zinc in mesquite ash.

\section{EXPLANATION}

QTag Alluvium and terrace gravels, undivided

Quartz monzonite porphyryIntrusive rocks

TKr Volcanics of Red Mountain-Chiefly rhyolite tuff. Drewes, 1971a; 1972

TKv Felsic volcanic rocks-Chiefly latite

Ka Trachyandesite of Meadow ValleyChiefly andesite porphyry. Simons, 1972

Kv Silicic volcanics-Simons, 1974

$\mathrm{J}$ - $\mathrm{Ki}$ Plutonic and volcanic rocks, undivided

Mount Wrightson Formation-Chiefly felsic volcanics

$\mathrm{J}-\mathrm{Yh}$ Hornblende-rich metamorphic and igneous rocks, undivide Contact-Locally concealed or inferred

ault-Dashed where approximate or inferred

Distribution of zinc in mesquite ash, in parts per million-Contours are shown with a solid line where the sample density is high. Where sample density is low, the dashed

$\begin{array}{r}1,500 \\ -\quad 1,000 \\ \hline\end{array}$

$=\begin{aligned} & 1,000 \\ & 500\end{aligned}$

- $\quad$ Sample site

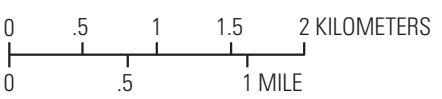

Base from U.S. Geological Survey digital data, 1:1,000,000, 2018 Geographic projection, decimal degrees

North American Datum of 1927

Geology modified from Drewes (1971a), Quinlan (1981, 1986 and Simons (1974). 


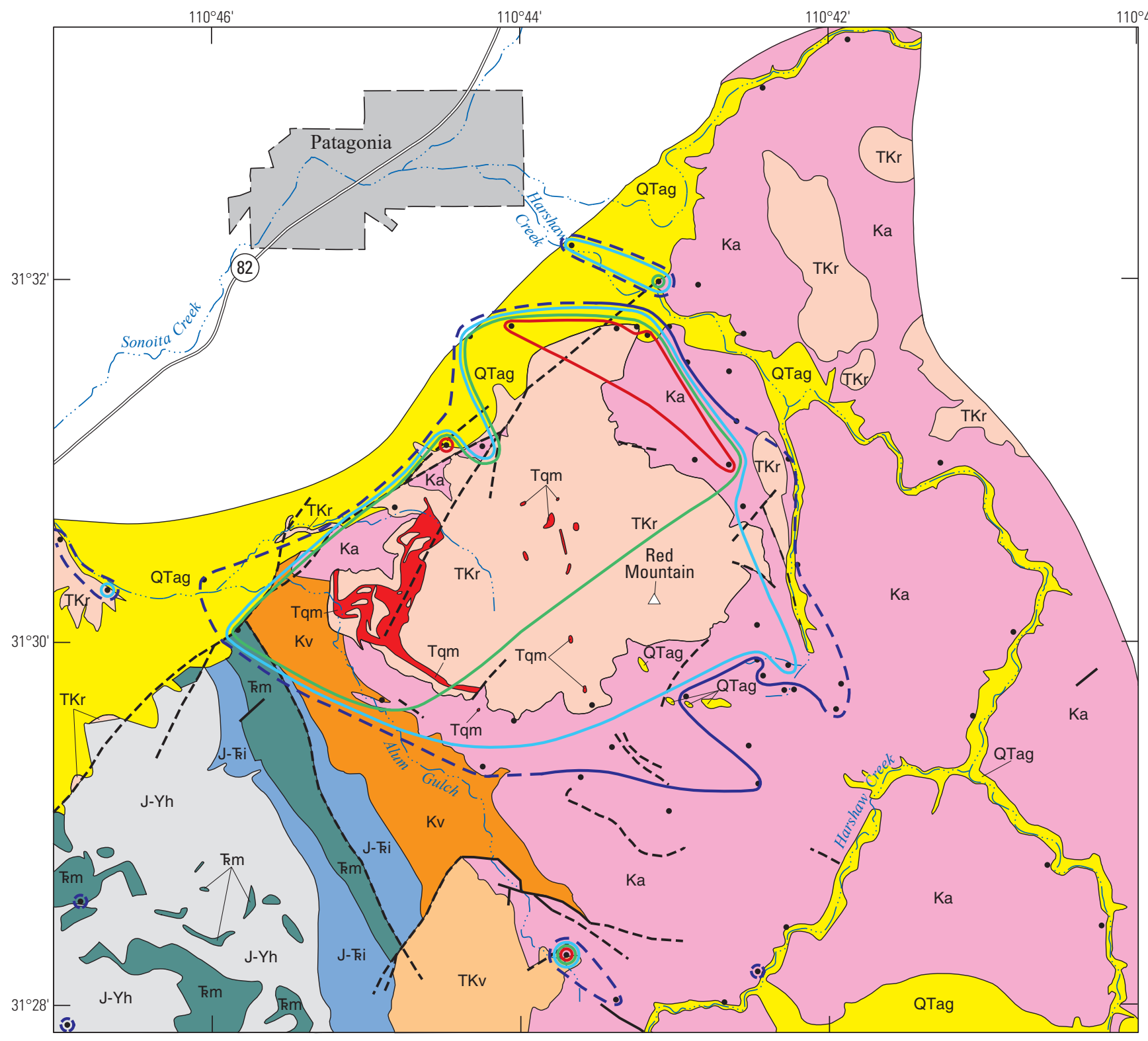

EXPLANATION

QTag Alluvium and terrace gravels, undivided

Quartz monzonite porphyryIntrusive rocks

TKr Volcanics of Red Mountain-Chiefly rhyolite tuff. Drewes, 1971a; 1972

TKV Felsic volcanic rocks-Chiefly latite

Ka Trachyandesite of Meadow ValleyChiefly andesite porphyry. Simons, 1972

KV Silicic volcanics-Simons, 1974

J-ki Plutonic and volcanic rocks, undivided

Mount Wrightson Formation-Chiefly felsic volcanics

$\mathrm{J}$-Yh Hornblende-rich metamorphic and igneous rocks, undivided Contact-Locally concealed or inferred

_ Fault-Dashed where approximate or inferred

Distribution of cadmium in mesquite ash, in parts per million-Contours are shown with a solid line where the sample density is high. Where sample density is $\longrightarrow \begin{array}{r}2.0 \\ -\quad 1.5 \\ 1.0\end{array}$ low, the contours are dashed

$\longrightarrow 1.0$

$-0.5$

- Sample site

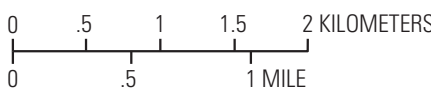

Base from U.S. Geological Survey digital data, 1:1,000,000, 2018 Geographic projection, decimal degrees North American Datum of 1927

Figure 103. Distribution of cadmium in mesquite ash. 


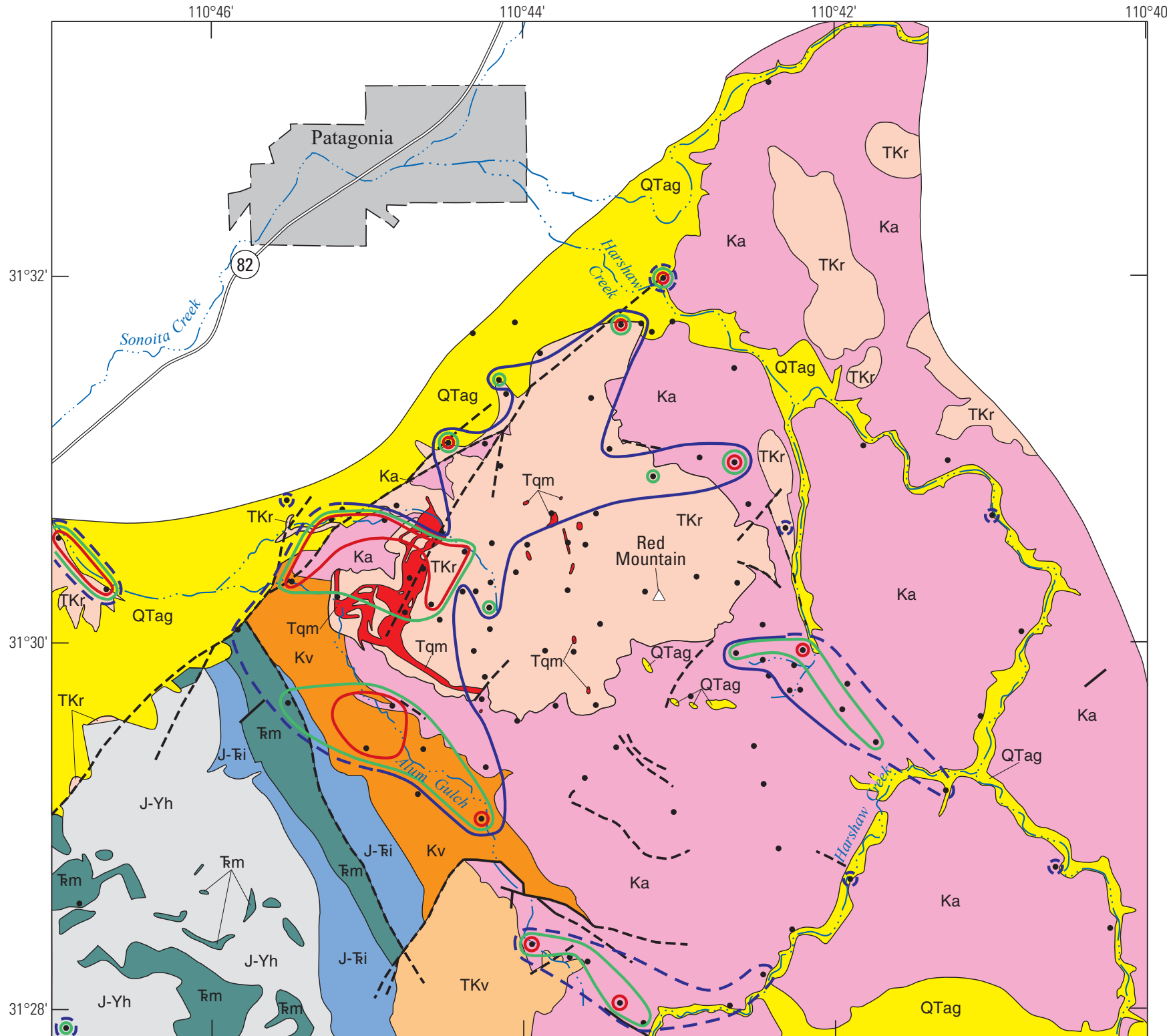

Figure 104. Distribution of zinc in oak ash

\section{EXPLANATION}

QTag Alluvium and terrace gravels, undivided

Quartz monzonite porphyryIntrusive rocks

TKr Volcanics of Red Mountain-Chiefly rhyolite tuff. Drewes, 1971a; 1972

TKv Felsic volcanic rocks-Chiefly latite

Ka Trachyandesite of Meadow ValleyChiefly andesite porphyry. Simons, 1972

Kv Silicic volcanics-Simons, 1974

$\mathrm{J}-\mathrm{ki}$ Plutonic and volcanic rocks, undivided

Mount Wrightson Formation-Chiefly felsic volcanics

$\mathrm{J}-\mathrm{Yh}$ Hornblende-rich metamorphic and igneous rocks, undivided Contact-Locally concealed or inferred

- Fault—Dashed where approximate or inferred

Distribution of zinc in oak ash, in parts per million-Contours are shown with a solid line where the sample density is high. Where sample density is low, the contours are dashed

$\begin{array}{r}-\quad 600 \\ -\quad 400 \\ \hline\end{array}$

$\longrightarrow \quad \begin{array}{r}400 \\ 200\end{array}$

- Sample site

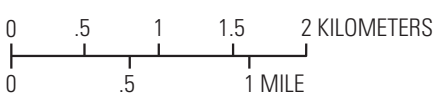

Base from U.S. Geological Survey digital data, 1:1,000,000, 2018 Geographic projection, decimal degrees

North American Datum of 1927

Geology modified from Drewes (1971a), Quinlan (1981, 1986) and Simons (1974). 


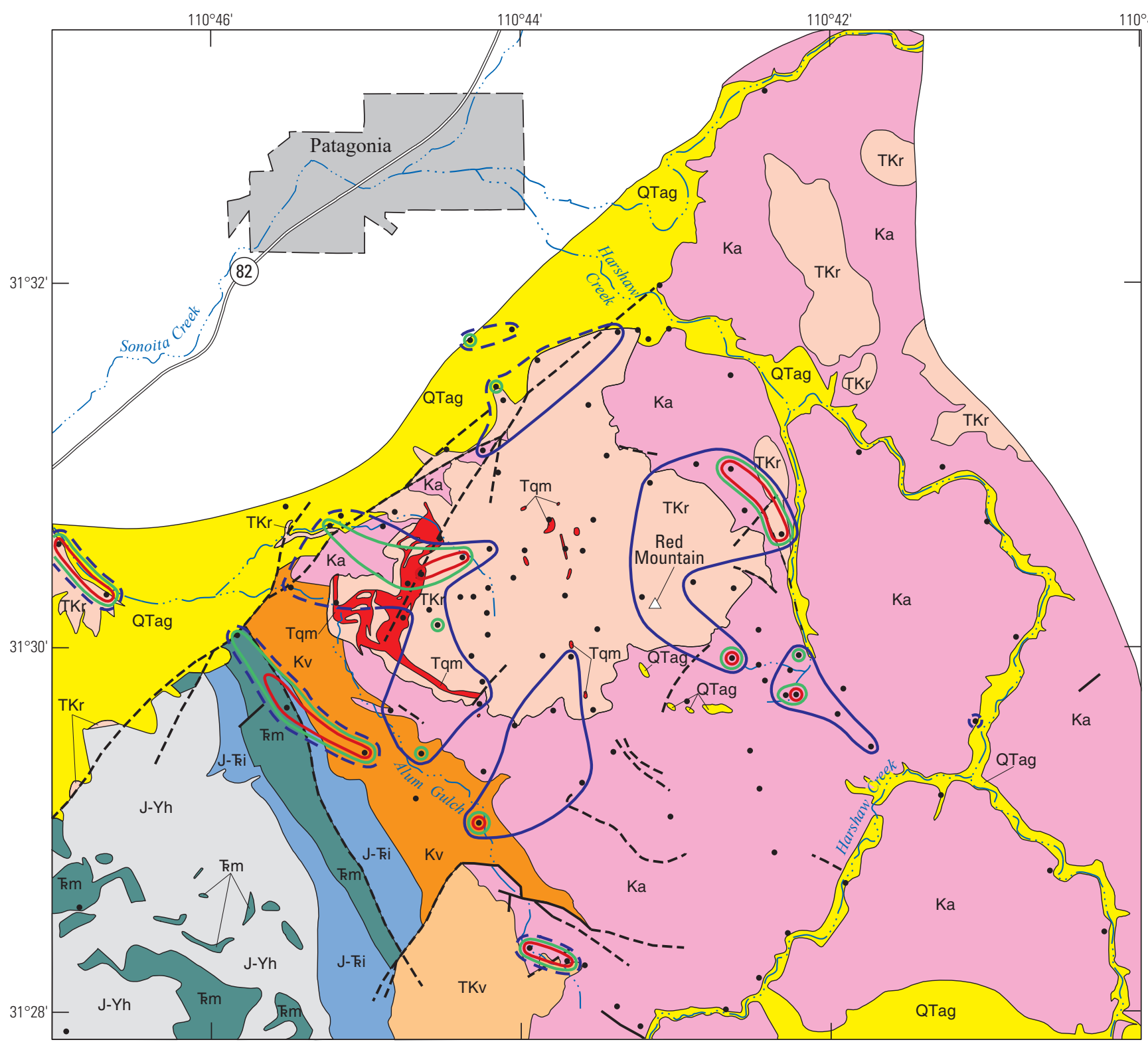

QTag Alluvium and terrace gravels, undivided

Quartz monzonite porphyryIntrusive rocks

\begin{tabular}{|l|l}
\hline$T K r$ & Volcanics of Red Mountain-Chiefly \\
\hline
\end{tabular} rhyolite tuff. Drewes, $1971 \mathrm{a} ; 1972$

TKV Felsic volcanic rocks-Chiefly latite

Ka Trachyandesite of Meadow Valley_ Chiefly andesite porphyry. Simons, 1972

KV Silicic volcanics-Simons, 1974

\begin{tabular}{|l|l}
\hline J-ki Plutonic and volcanic rocks, \\
\hline
\end{tabular} undivided

Mount Wrightson Formation-Chiefly felsic volcanics

$\mathrm{J}-\mathrm{Yh}$ Hornblende-rich metamorphic and igneous rocks, undivided Contact-Locally concealed or

inferred
Fault-Dashed where approximate or inferred

Distribution of cadmium in oak ash, in parts per million-Contours are shown with a solid line where the sample density is high. Where sample density is low, the contours

$\begin{array}{r}50 \\ \square \quad 30 \\ \hline \quad 15\end{array}$ are dashed

- Sample site

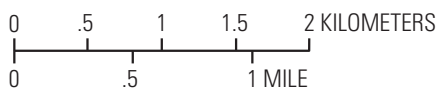

Base from U.S. Geological Survey digital data, 1:1,000,000, 2018 Geographic projection, decimal degrees North American Datum of 192

Figure 105. Distribution of cadmium in oak ash. 


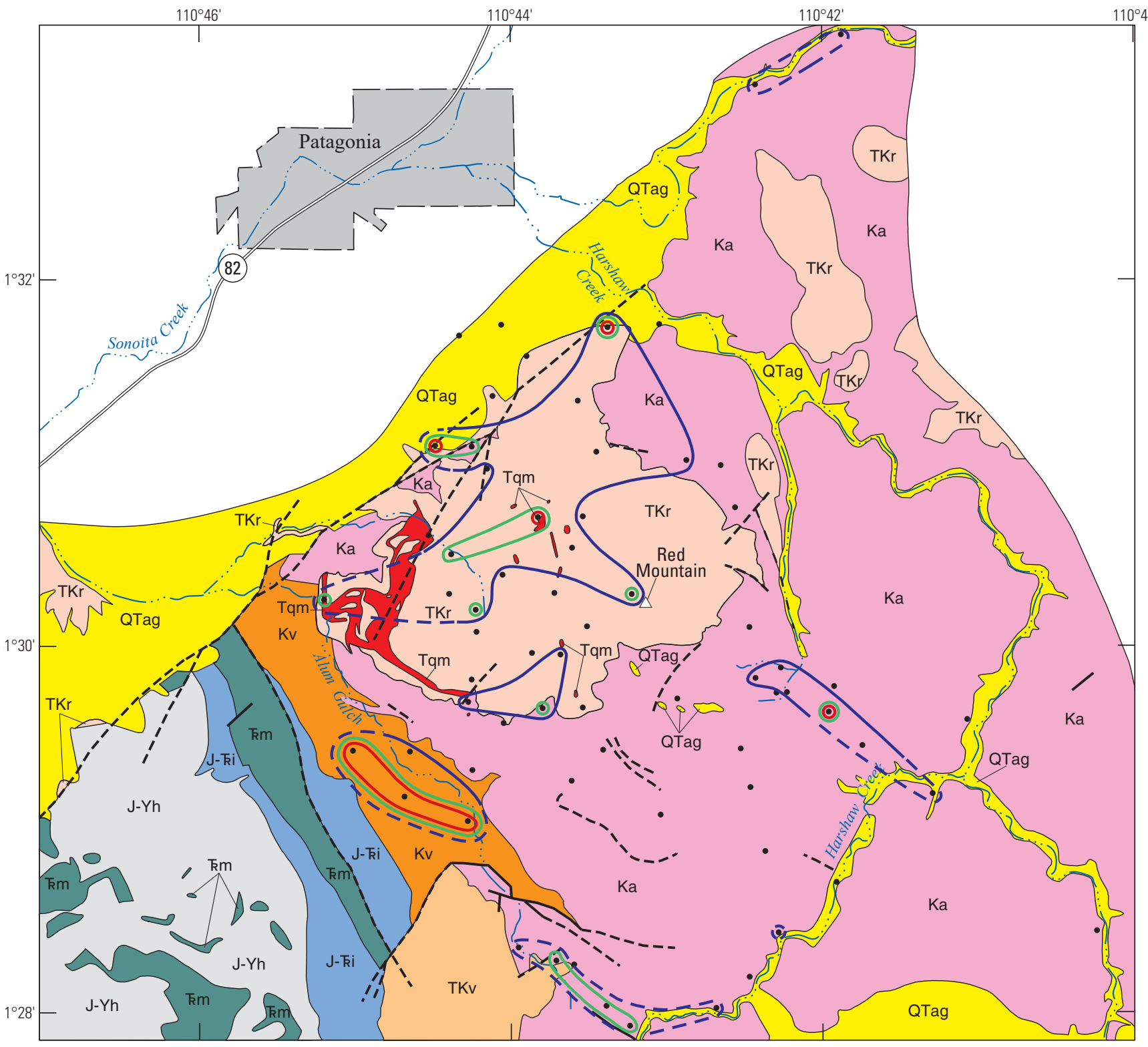

\section{EXPLANATION}

QTag Alluvium and terrace gravels, undivided

Quartz monzonite porphyryIntrusive rocks

TKr Volcanics of Red Mountain-Chiefly rhyolite tuff. Drewes, 1971a; 1972

TKv Felsic volcanic rocks-Chiefly latite

Ka Trachyandesite of Meadow ValleyChiefly andesite porphyry. Simons, 1972

Kv Silicic volcanics-Simons, 1974

$\mathrm{J}-\mathrm{ki}$ Plutonic and volcanic rocks, undivided

Mount Wrightson Formation-Chiefly felsic volcanics

$\mathrm{J}$-Yh Hornblende-rich metamorphic and igneous rocks, undivided

Contact-Locally concealed or inferred

ault-Dashed where approximate or inferred

Distribution of zinc in juniper ash, in parts per million-Contours are shown with a solid line where the sample density is high. Where sample density is low, the contours are dashed

$\begin{array}{r}-500 \\ -\quad 300 \\ \hline\end{array}$

300
200

- Sample site

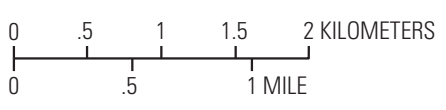

Base from U.S. Geological Survey digital data, 1:1,000,000, 2018 Geographic projection, decimal degrees

North American Datum of 1927

Geology modified from Drewes (1971a), Quinlan (1981, 1986), and Simons (1974).

Figure 106. Distribution of zinc in juniper ash. 


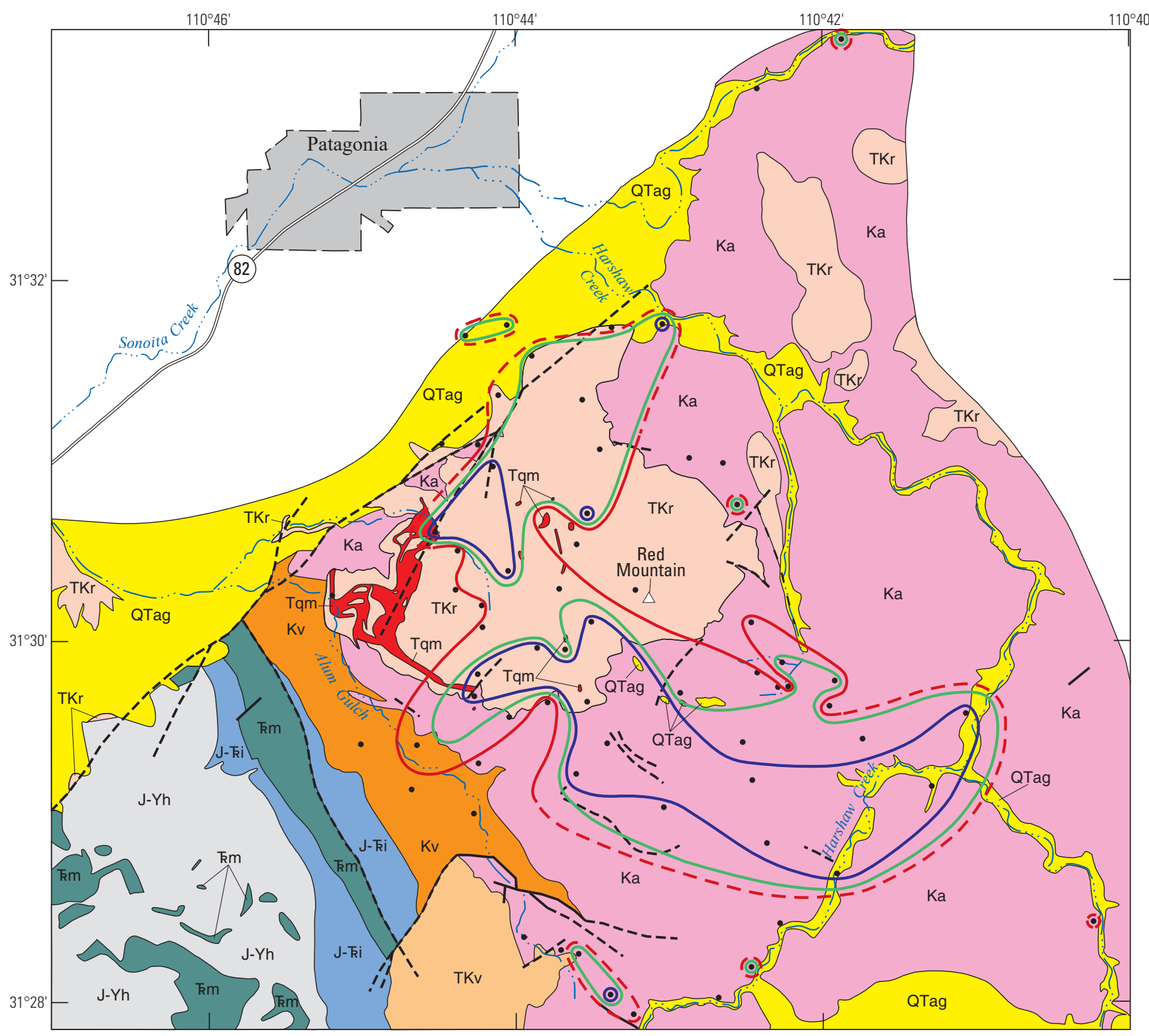

\section{EXPLANATION}

QTag Alluvium and terrace gravels,

$$
\text { undivided }
$$

Quartz monzonite porphyryIntrusive rocks

TKr Volcanics of Red Mountain-Chiefly rhyolite tuff. Drewes, 1971a; 1972

TKv Felsic volcanic rocks-Chiefly latite

$\mathrm{Ka}$ Trachyandesite of Meadow ValleyChiefly andesite porphyry. Simons, 1972

Silicic volcanics-Simons, 1974

$\mathrm{J}-\mathrm{ki}$ Plutonic and volcanic rocks undivided

Mount Wrightson Formation-Chiefly felsic volcanics

$\mathrm{J}-\mathrm{Yh}$ Hornblende-rich metamorphic and

$$
\text { igneous rocks, undivided }
$$
inferred

Fault-Dashed where approximate or inferred

Distribution of cadmium in juniper ash, in parts per million-Contours are shown with a solid line where the sample density is high. Where sample density is low, the

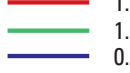
contours are dashed

- $\quad$ Sample site

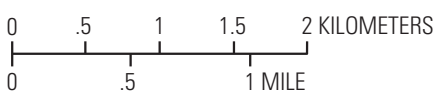

Base from U.S. Geological Survey digital data, 1:1,000,000, 2018 Geographic projection, decimal degrees North American Datum of 1927 and Simons (1974).

Figure 107. Distribution of cadmium in juniper ash. 
Sodium.-This major element is essential for plants (Brooks, 1983). However, the ash/soil ratios for the three species are very low, ranging from 0.14 to 0.23 (tables 6-8), implying that sodium is not highly concentrated by these species. The median values for sodium are $0.07,0.09$, and 0.12 percent for mesquite, oak, and juniper ash, respectively (tables 6-8). The rock and soil distributions for sodium exhibit negative anomalies centered over the rhyolite tuff unit (figs. 74 and 75). In contrast, the distributions of all three plant species show low-level but distinct positive anomalies over this unit (figs. 111-113). However, the distribution of sodium in oak ash is more concentrated over the main outcrops of quartz monzonite porphyry than it is in mesquite and juniper ash. The discrepancy between the negative rock and soil distributions and the positive plant distributions seems to reflect the essentiality of sodium in plants even though the ash/soil ratios are low.

Manganese.-This minor element is also essential for plants (Brooks, 1983). The ash/soil ratios for manganese in mesquite and juniper ash are 0.67 and 1.9, respectively (tables 6 and 8). In the case of oak ash, the ratio is an unusually high 8.8 , with manganese concentrations ranging as high as $20,980 \mathrm{ppm}$, or about 2.1 percent, in ash (table 7). These differences in manganese ash/soil ratios indicate that this element is accumulated quite differently in each of these three plant species, probably as a result of genetic differences.

The median values for manganese are $381,5,025$, and $1,090 \mathrm{ppm}$ for mesquite, oak, and juniper ash, respectively (tables 6-8). The distribution of manganese in soils (fig. 69) exhibits a negative anomaly centered over the rhyolite tuff unit. The distributions for all three plant species show broad areas of low manganese concentrations that differ for each species. The low areas are not entirely confined to the area of visible alteration (fig. 41) or to the area of the rhyolite tuff unit (figs. 114-116). The area of low manganese concentrations for all three species in the andesite unit south of the rhyolite tuff unit is not present in the distribution of manganese in soils (fig. 69) and is thus thought to be a result of elevation-related climate parameters or possibly groundwater regimens rather than to the chemical effects of deposit-related minerals or lithology. Negative anomalies, especially for manganese in oak ash, are also present along the Harshaw Creek drainages. Their possible association with contamination from past mining is implied but not clearly understood.

Magnesium.-This major element is also essential for plants (Brooks, 1983). The ash/soil ratios for the three species range from 5.0 to 8.6 (tables 6-8), indicating that magnesium is strongly accumulated in all three of these species; however, all three species exhibit negative anomalies.

The median values for magnesium are $2.35,3.20$, and 4.04 percent for mesquite, oak, and juniper ash, respectively (tables 6-8). Sample sites for magnesium in the mesquite ash are lacking over the rhyolite tuff unit; thus, it is not possible to accurately describe the overall distribution of magnesium for this species (fig. 117). The distributions of magnesium in the ash of oak and juniper (figs. 118-119) show negative anomalies that are centered over the rhyolite tuff unit and are similar to the distribution of magnesium in soil samples (fig. 73). However, unlike the distribution of magnesium in soils, distributions of low concentrations for all three plant species extend in a broad area to the southeast of Red Mountain, suggesting that factors other than lithology are affecting the magnesium concentrations in plants in that area. 


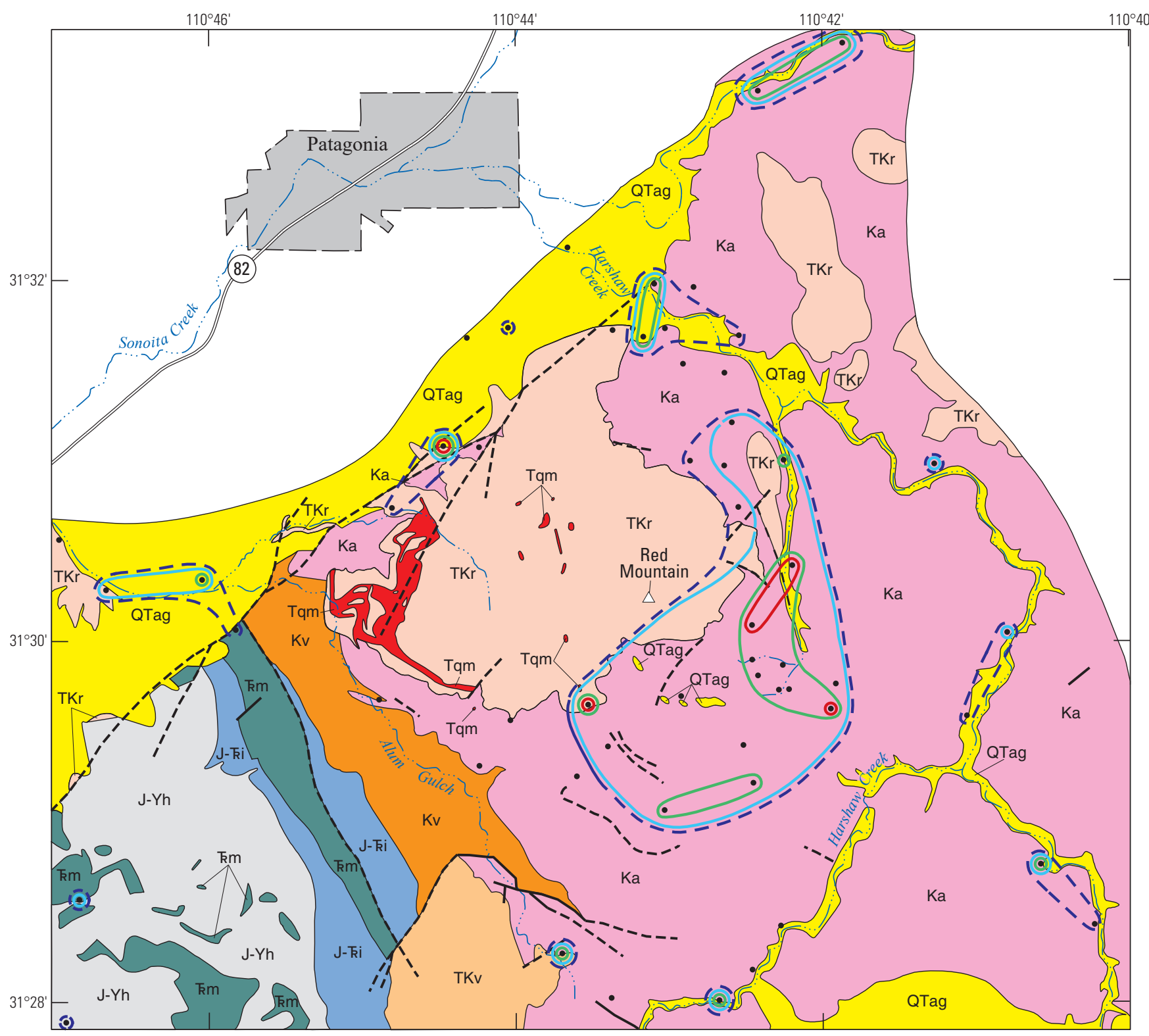

QTag Alluvium and terrace gravels, undivided

Quartz monzonite porphyryIntrusive rocks

TKr Volcanics of Red Mountain - Chiefly rhyolite tuff. Drewes, 1971a; 1972

TKv Felsic volcanic rocks-Chiefly latite

$\mathrm{Ka}$ Trachyandesite of Meadow ValleyChiefly andesite porphyry. Simons, 1972

Kv Silicic volcanics-Simons, 1974

$\mathrm{J}-\mathrm{Ki}$ Plutonic and volcanic rocks, undivided

Mount Wrightson Formation-Chiefly felsic volcanics

$\mathrm{J}-\mathrm{Yh}$ Hornblende-rich metamorphic and igneous rocks, undivided Contact-Locally concealed or inferred

- Fault-Dashed where approximate or inferred

Distribution of selenium in mesquite ash, in parts per million-Contours are shown with a solid line where the sample density is high. Where sample density is low, the contours are dashed

\begin{tabular}{r}
$\square .0$ \\
$\square$ \\
\hline \\
1.0
\end{tabular}

-1.5
$-\quad 1.0$

- $\quad$ Sample site

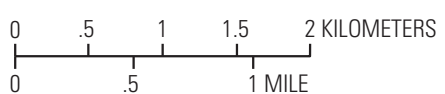

Base from U.S. Geological Survey digital data, 1:1,000,000, 2018 Geographic projection, decimal degrees North American Dat

Figure 108. Distribution of selenium in mesquite ash. 


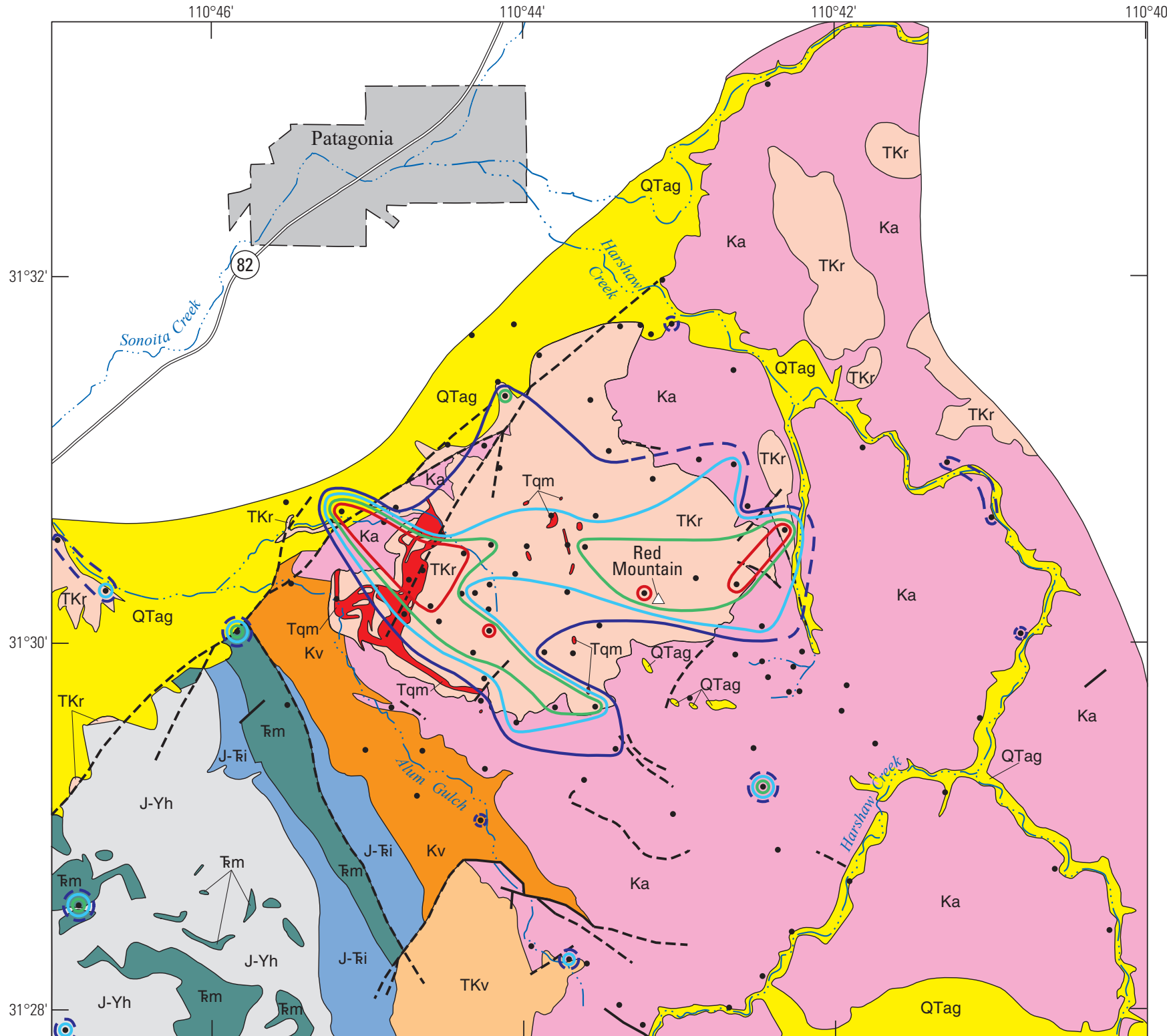

Figure 109. Distribution of selenium in oak ash.

\section{EXPLANATION}

QTag Alluvium and terrace gravels undivided

Quartz monzonite porphyryIntrusive rocks

TKr Volcanics of Red Mountain-Chiefly rhyolite tuff. Drewes, 1971a; 1972

TKv Felsic volcanic rocks-Chiefly latite

$\mathrm{Ka}$ Trachyandesite of Meadow ValleyChiefly andesite porphyry. Simons, 1972

Silicic volcanics-Simons, 197

Plutonic and volcanic rocks, undivided

Mount Wrightson Formation-Chiefly felsic volcanics

$\mathrm{J}-\mathrm{Yh}$ Hornblende-rich metamorphic and igneous rocks, undivided Contact-Locally concealed or inferred

— Fault—Dashed where approximate or inferred

Distribution of selenium in oak ash, in parts per million-Contours are shown with a solid line where the sample density is high. Where sample density is low, the contours are dashed

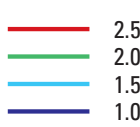

- Sample site

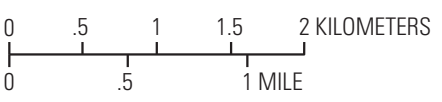

Base from U.S. Geological Survey digital data, 1:1,000,000, 2018 Geographic projection, decimal degrees

North American Datum of 1927

Geology modified from Drewes (1971a), Quinlan $(1981,1986)$ and Simons (1974). 


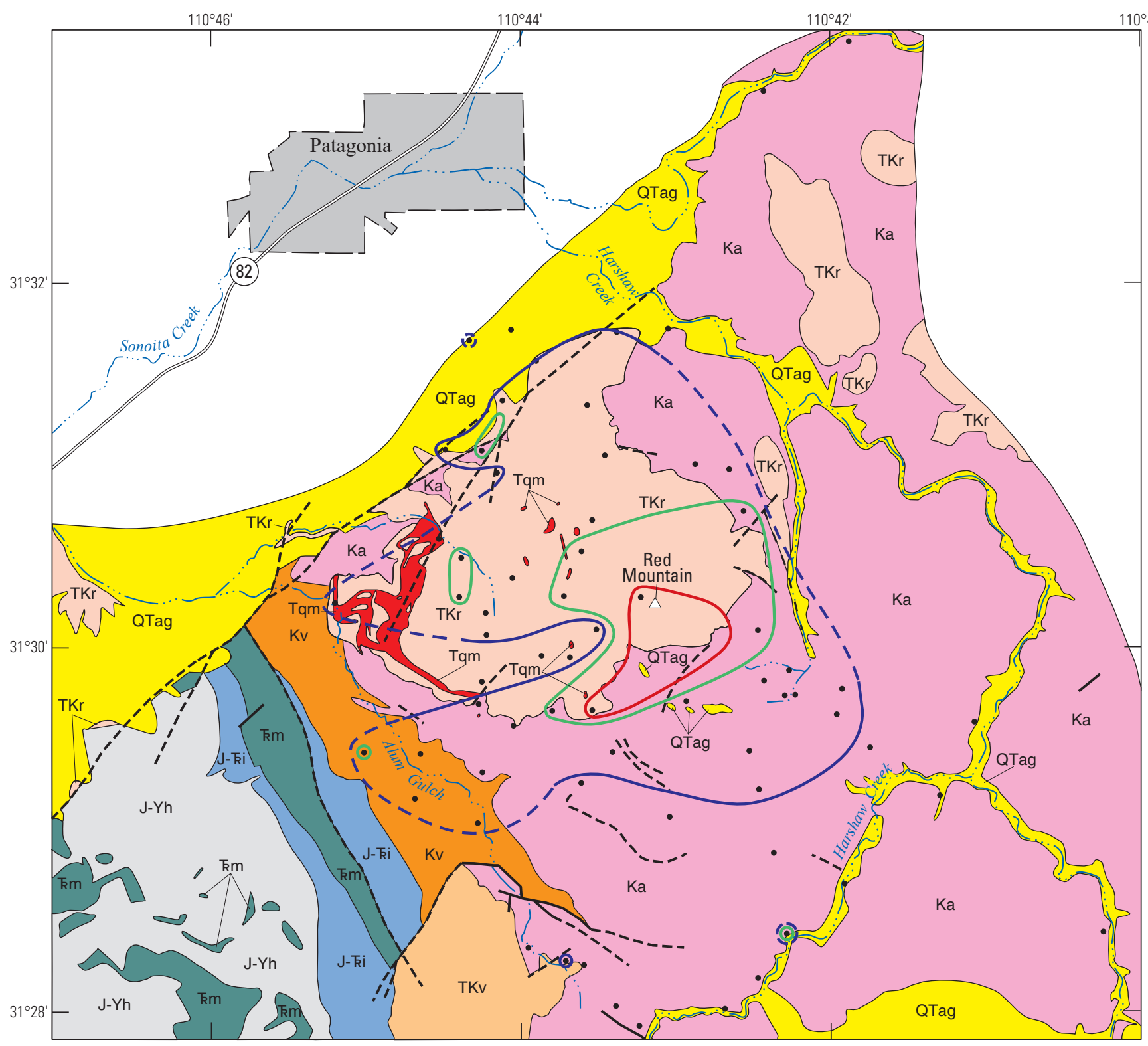

QTag Alluvium and terrace gravels,

$$
\text { undivided }
$$

Quartz monzonite porphyryIntrusive rocks

TKr Volcanics of Red Mountain - Chiefly rhyolite tuff. Drewes, 1971a; 1972

TKv Felsic volcanic rocks-Chiefly latite

Ka Trachyandesite of Meadow ValleyChiefly andesite porphyry. Simons, 1972

Kv Silicic volcanics-Simons, 1974

$\mathrm{J}-\mathrm{ki}$ Plutonic and volcanic rocks, undivided

Mount Wrightson Formation-Chiefly felsic volcanics

$\mathrm{J}-\mathrm{Yh}$ Hornblende-rich metamorphic and

$$
\text { igneous rocks, undivided }
$$

Contact-Locally concealed or inferred

- Fault-Dashed where approximate or inferred

Distribution of selenium in juniper ash, in parts per million-Contours are shown with a solid line where the sample density is high. Where sample density is low, the contours a

Figure 110. Distribution of selenium in juniper ash. Geographic projection, decimal degrees North American Datum of 192 


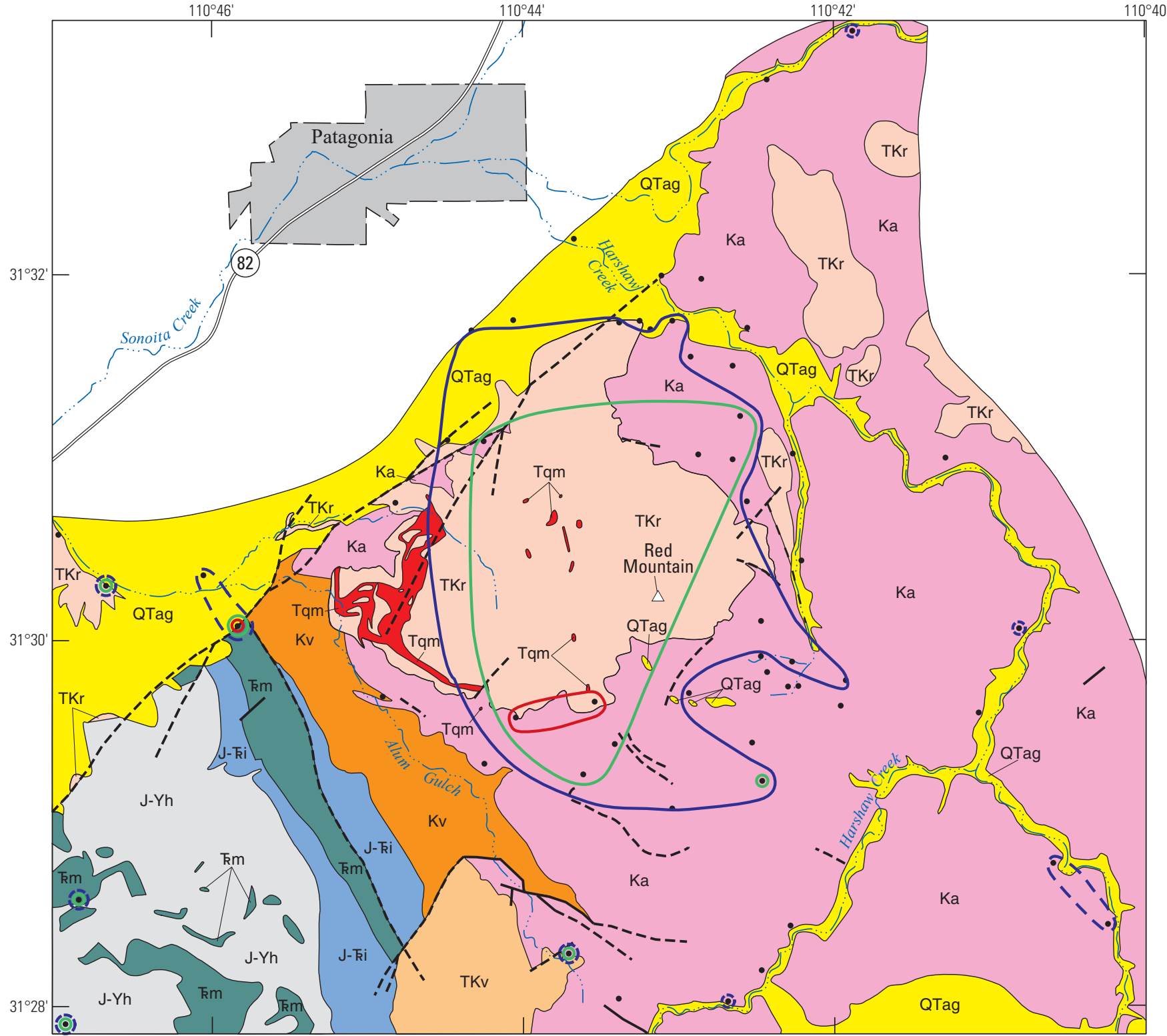

Figure 111. Distribution of sodium in mesquite ash.

\section{EXPLANATION}

QTag Alluvium and terrace gravels, undivided

Quartz monzonite porphyryIntrusive rocks

TKr Volcanics of Red Mountain-Chiefly rhyolite tuff. Drewes, 1971a; 1972

TKv Felsic volcanic rocks-Chiefly latite

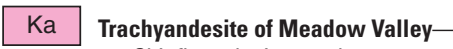
Chiefly andesite porphyry. Simons, 1972

Kv Silicic volcanics-Simons, 1974

$\mathrm{J}$ - $\mathrm{Ki}$ Plutonic and volcanic rocks, undivided

Mount Wrightson Formation-Chiefly felsic volcanics

$\mathrm{J}-\mathrm{Yh}$ Hornblende-rich metamorphic and igneous rocks, undivide Contact-Locally concealed or inferred

ault-Dashed where approximate or inferred

Distribution of sodium in mesquite ash, in percent-Contours are shown with a solid line where the sample density is high. Where sample density is low, the

0.15
0.10

$\longrightarrow \begin{aligned} & 0.10 \\ & 0.07\end{aligned}$

- Sample site

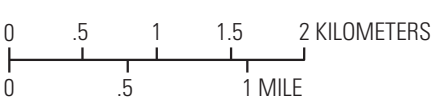

Base from U.S. Geological Survey digital data, 1:1,000,000, 2018 Geographic projection, decimal degrees

North American Datum of 1927

Geology modified from Drewes (1971a), Quinlan (1981, 1986), and Simons (1974). 


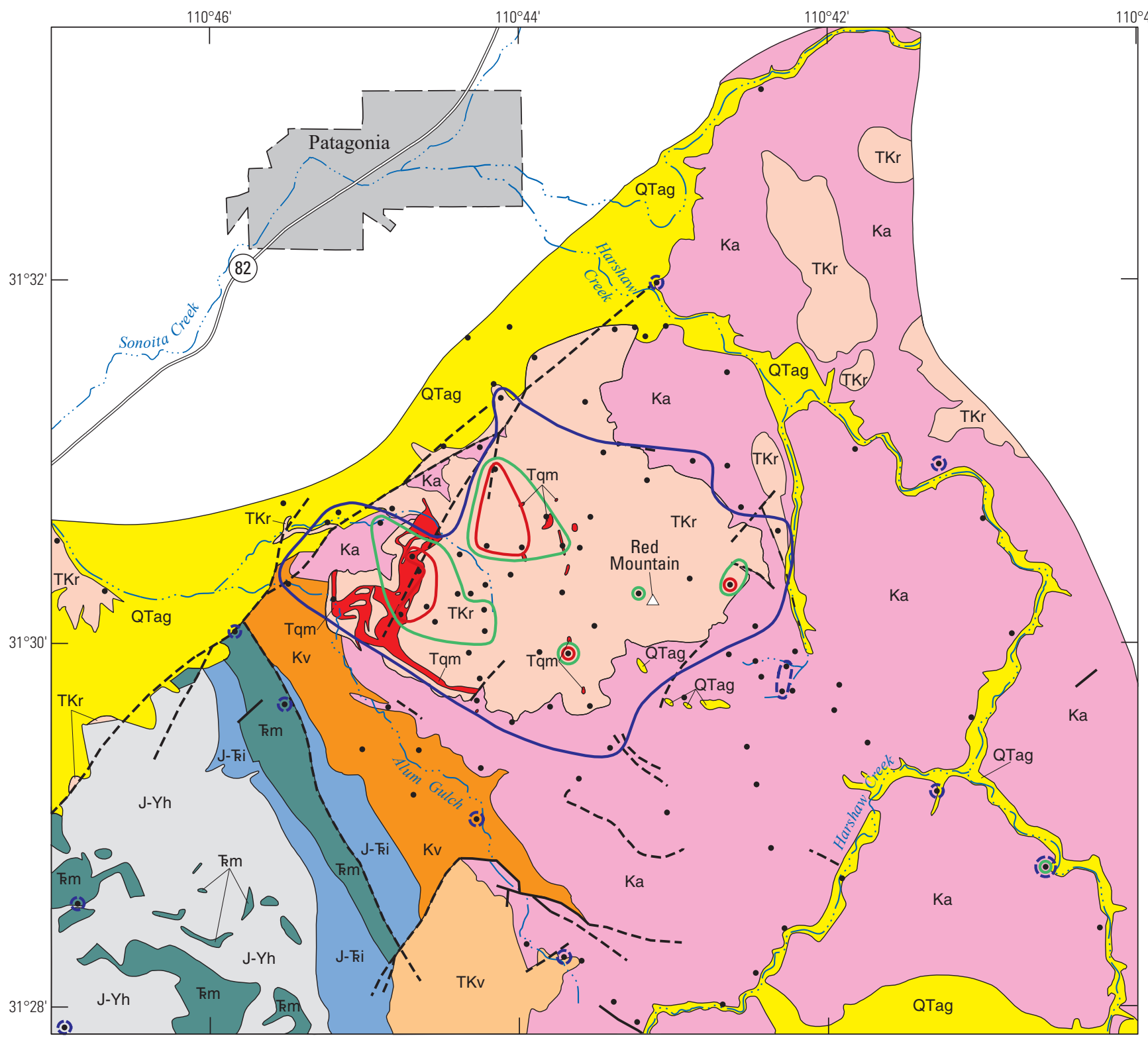

\section{EXPLANATION}

QTag Alluvium and terrace gravels, undivided

Quartz monzonite porphyryIntrusive rocks

TKr Volcanics of Red Mountain—Chiefly rhyolite tuff. Drewes, 1971a; 1972

TKv Felsic volcanic rocks-Chiefly latite

Ka Trachyandesite of Meadow ValleyChiefly andesite porphyry.

$$
\text { Simons, } 1972
$$

Kv Silicic volcanics-Simons, 1974

$\mathrm{J}-\mathrm{ki}$ Plutonic and volcanic rocks. undivided

Mount Wrightson Formation-Chiefly felsic volcanics

$\mathrm{J}-\mathrm{Yh}$ Hornblende-rich metamorphic and

$$
\text { igneous rocks, undivided }
$$

Contact-Locally concealed or inferred

Fault-Dashed where approximat or inferred

Distribution of sodium in oak ash, in percentContours are shown with a solid line where the sample density is high. Where sample density is low, the contours are dashed

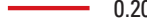

- Sample site

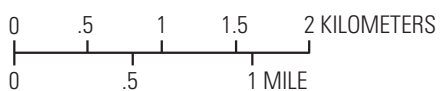

Base from U.S. Geological Survey digital data, 1:1,000,000, 2018 Geographic projection, decimal degrees North American Datum of 1927 and Simons (1974).

Figure 112. Distribution of sodium in oak ash. 


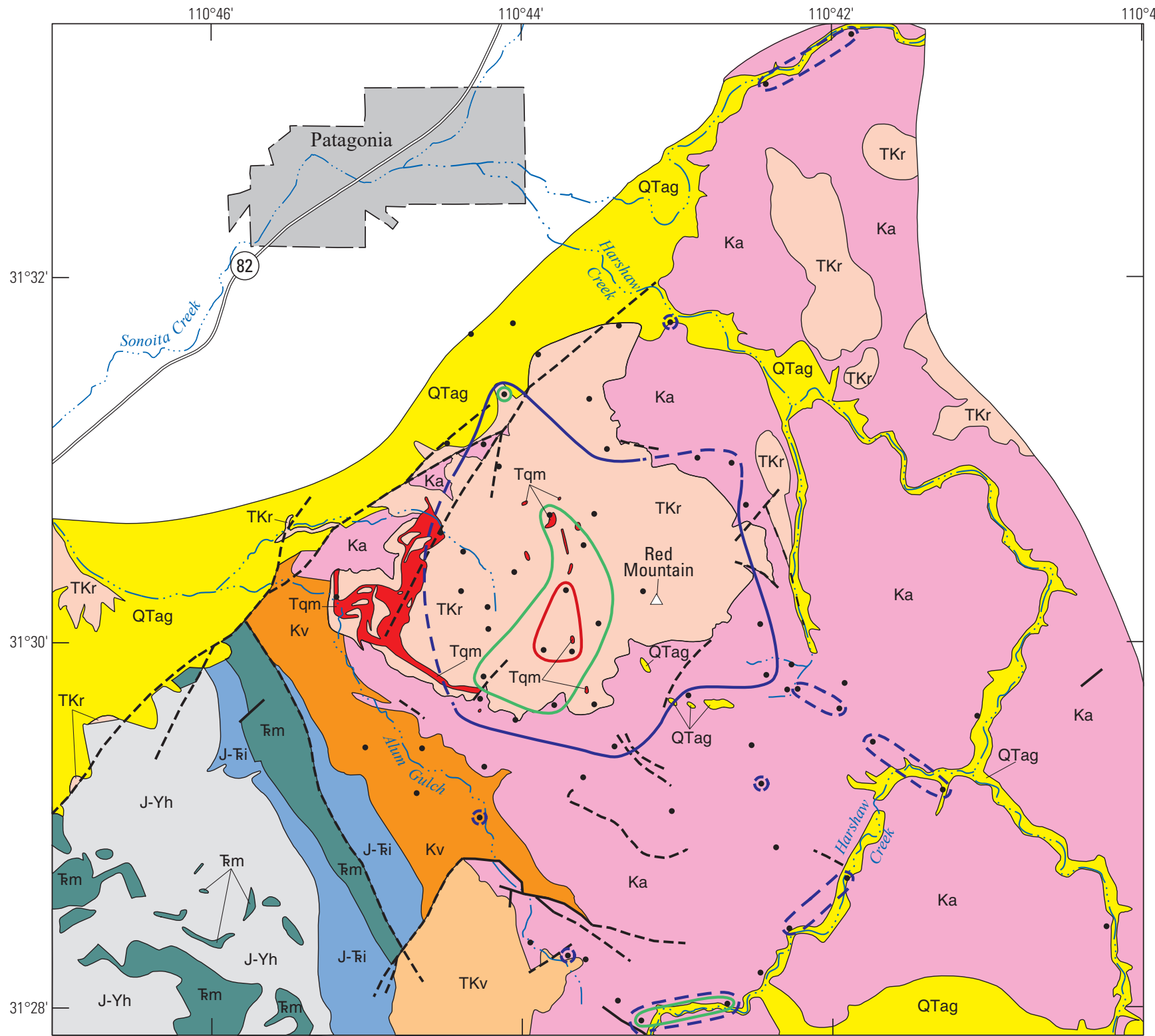

Figure 113. Distribution of sodium in juniper ash

\section{EXPLANATION}

QTag Alluvium and terrace gravels undivided

Quartz monzonite porphyryIntrusive rocks

TKr Volcanics of Red Mountain-Chiefly rhyolite tuff. Drewes, 1971a; 1972

TKv Felsic volcanic rocks-Chiefly latite

$\mathrm{Ka}$ Trachyandesite of Meadow ValleyChiefly andesite porphyry. Simons, 1972

Silicic volcanics-Simons, 197

$\mathrm{J}$ - Ki Plutonic and volcanic rocks, undivided

Mount Wrightson Formation-Chiefly felsic volcanics

$\mathrm{J}-\mathrm{Yh}$ Hornblende-rich metamorphic and igneous rocks, undivided Contact-Locally concealed or

inferred or inferred

Distribution of sodium in juniper ash, in percent-Contours are shown with a solid line where the sample density is high. Where sample density is low, the contours are dashed

\begin{tabular}{l}
0.30 \\
\hline
\end{tabular} 0.20

- 0.10

- Sample site

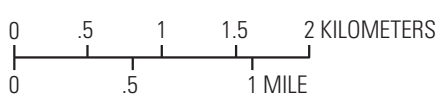

Base from U.S. Geological Survey digital data, 1:1,000,000, 2018 Geographic projection, decimal degrees

North American Datum of 1927

Geology modified from Drewes (1971a), Quinlan $(1981,1986)$ and Simons (1974). 


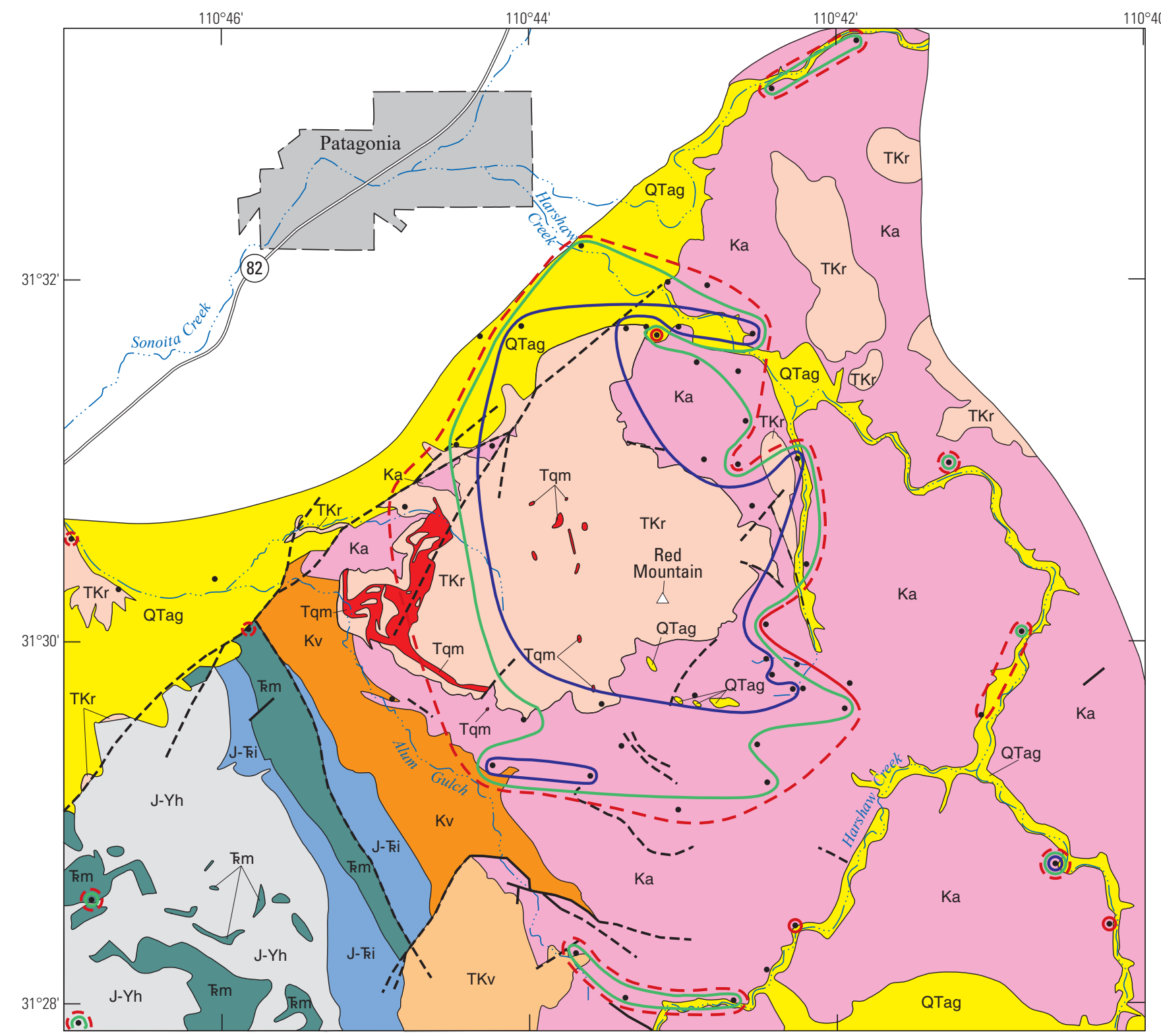

\section{EXPLANATION}

QTag Alluvium and terrace gravels, undivided

Quartz monzonite porphyryIntrusive rocks

TKr Volcanics of Red Mountain - Chiefly rhyolite tuff. Drewes, 1971a; 1972

TKv Felsic volcanic rocks-Chiefly latite

Ka Trachyandesite of Meadow ValleyChiefly andesite porphyry. Simons, 1972

Kv Silicic volcanics-Simons, 197

$\mathrm{J}-\mathrm{Ki}$ Plutonic and volcanic rocks, undivided

Mount Wrightson Formation-Chiefly felsic volcanics

$\mathrm{J}-\mathrm{Yh}$ Hornblende-rich metamorphic and

$$
\text { igneous rocks, undivided }
$$

$$
\text { inferred }
$$

— Fault-Dashed where approximate or inferred

Distribution of manganese in mesquite ash in parts per million-Contours are shown with a solid line where the sample density is high. Where sample density is low, the contours are dashed

- $\quad$ Sample site

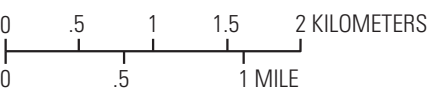

Base from U.S. Geological Survey digital data, 1:1,000,000, 2018 Geographic projection, decimal degrees North American Datum of 1927

Figure 114. Distribution of manganese in mesquite ash. 


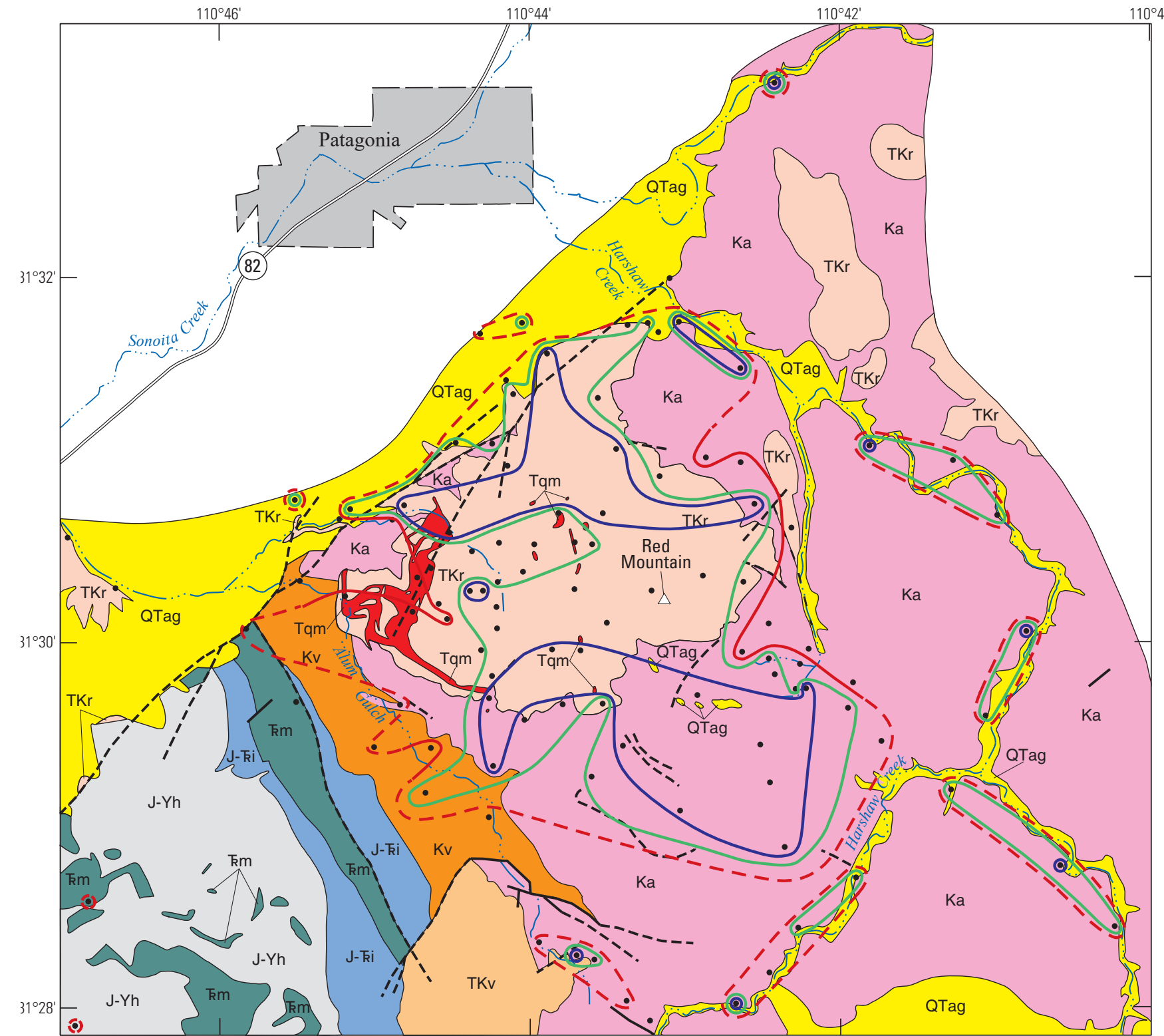

Figure 115. Distribution of manganese in oak ash.

\section{EXPLANATION}

QTag Alluvium and terrace gravels, undivided

Quartz monzonite porphyryIntrusive rocks

TKr Volcanics of Red Mountain—Chiefly rhyolite tuff. Drewes, 1971a; 1972

TKv Felsic volcanic rocks-Chiefly latite

$\mathrm{Ka}$ Trachyandesite of Meadow ValleyChiefly andesite porphyry. Simons, 1972

Kv Silicic volcanics-Simons, 1974

$\mathrm{J}-\mathrm{Ki}$ Plutonic and volcanic rocks, undivided

Mount Wrightson Formation-Chiefly felsic volcanics

$\mathrm{J}-\mathrm{Yh}$ Hornblende-rich metamorphic and igneous rocks, undivided Contact-Locally concealed or inferred

Fault-Dashed where approximate or inferred

Distribution of manganese in oak ash, in parts per million-Contours are shown with a solid line where the sample density is high. Where sample density is low, the contours are dashed

- $\begin{array}{r}5,000 \\ 3,000\end{array}$

- Sample site

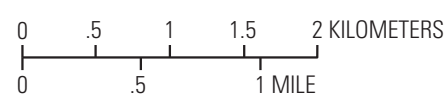

Base from U.S. Geological Survey digital data, 1:1,000,000, 2018 Geographic projection, decimal degrees North American Datum of 1927

Geology modified from Drewes (1971a), Quinlan $(1981,1986)$ and Simons (1974). 


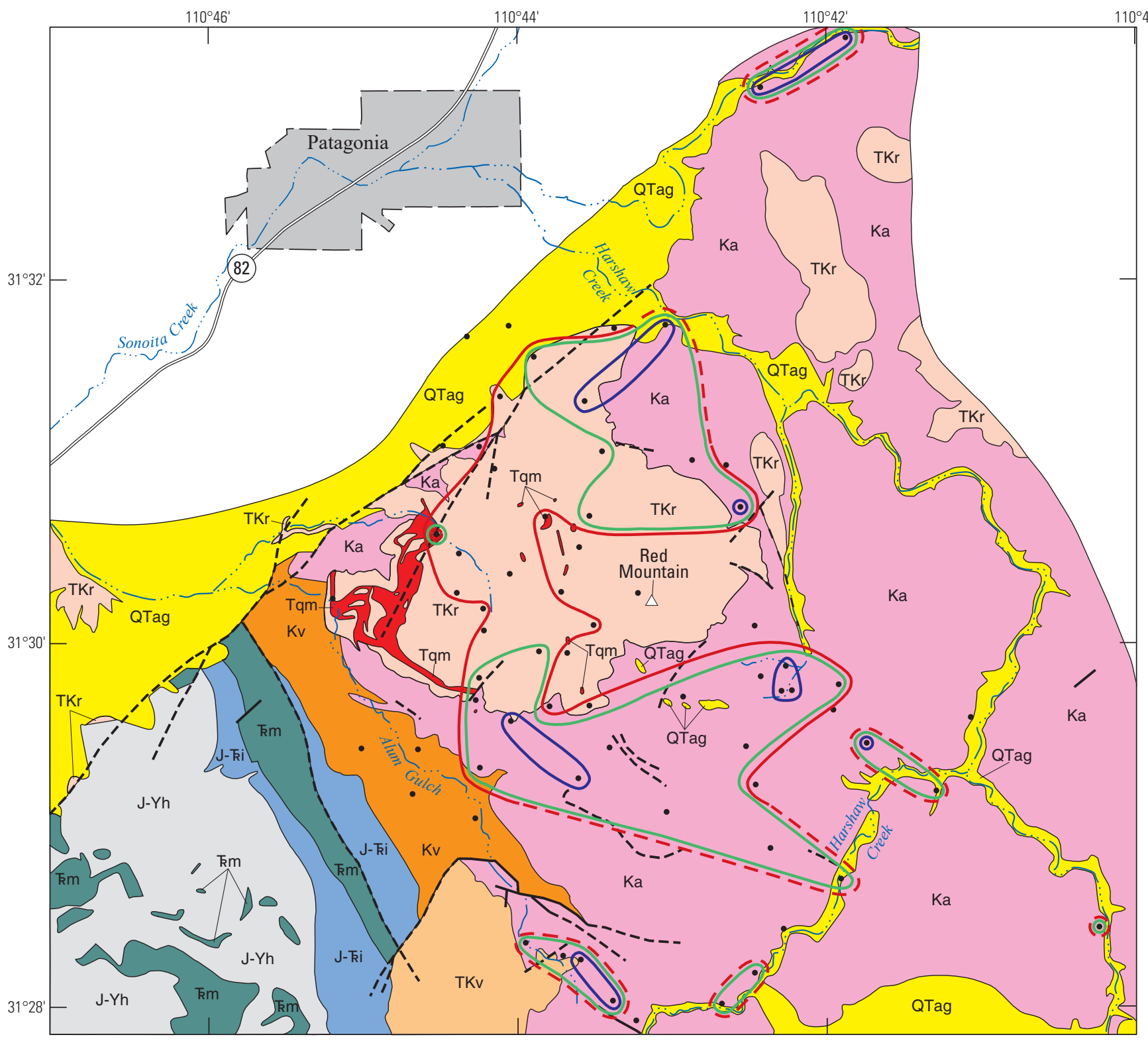

QTag Alluvium and terrace gravels, undivided

Quartz monzonite porphyryIntrusive rocks

TKr Volcanics of Red Mountain—Chiefly rhyolite tuff. Drewes, 1971 a; 1972

TKV Felsic volcanic rocks-Chiefly latite

Ka Trachyandesite of Meadow ValleyChiefly andesite porphyry. Simons, 1972

Kv Silicic volcanics-Simons, 1974

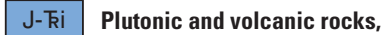
undivided

Mount Wrightson Formation-Chiefly felsic volcanics

J-Yh Hornblende-rich metamorphic and igneous rocks, undivided Contact—Locally concealed or

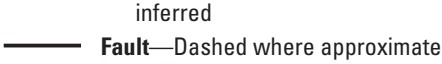
or inferred

Distribution of manganese in juniper ash, in parts per million-Contours are shown with a solid line where the sample density is high. Where sample density is low, the contours are dashed

$\begin{array}{r}\square, 400 \\ -\quad 1,100 \\ \hline\end{array}$ 1,100
700

- Sample site

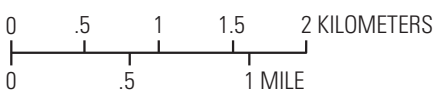

Base from U.S. Geological Survey digital data, 1:1,000,000, 2018 Geographic projection, decimal degrees North American Datum of 1927

Figure 116. Distribution of manganese in juniper ash. 


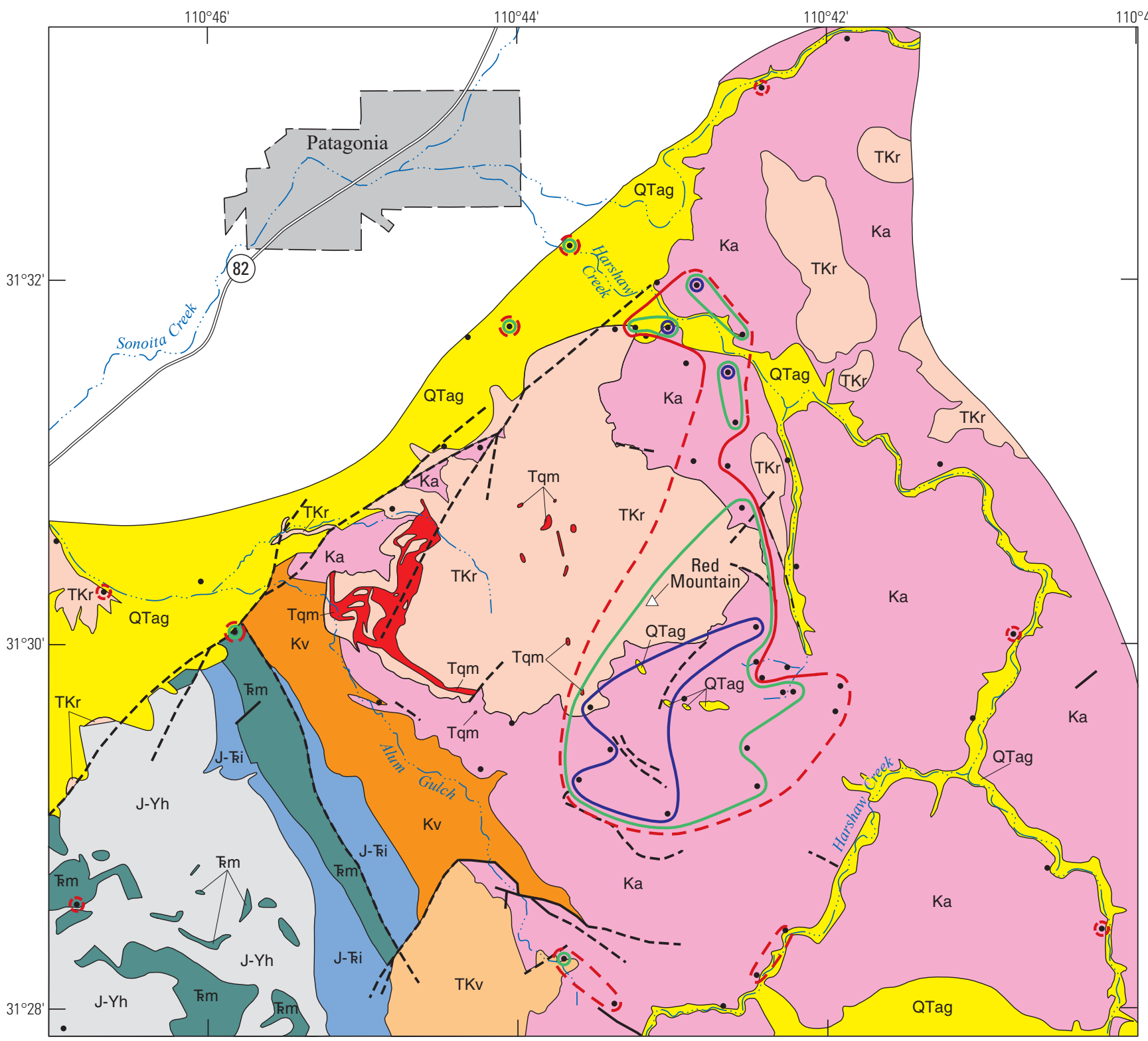

$\prod^{\circ}$ EXPLANATION

\section{QTag Alluvium and terrace gravels,} undivided

Quartz monzonite porphyryIntrusive rocks

TKr Volcanics of Red Mountain-Chiefly rhyolite tuff. Drewes, 1971a; 1972

TKv Felsic volcanic rocks-Chiefly latite

Ka Trachyandesite of Meadow ValleyChiefly andesite porphyry. Simons, 1972

Kv Silicic volcanics-Simons, 1974

$\mathrm{J}-\mathrm{ki}$ Plutonic and volcanic rocks, undivided

$\mathrm{km}$ Mount Wrightson Formation-Chiefly felsic volcanics

$\mathrm{J}-\mathrm{Yh}$ Hornblende-rich metamorphic and igneous rocks, undivided Contact-Locally concealed or

inferred
Fault-Dashed where approximate or inferred

Distribution of magnesium in mesquite ash

in percent-Contours are shown with a solid line where the sample density is high. Where sample density is low, the contours are dashed

-2.50
-

2.00
1.50

- Sample site

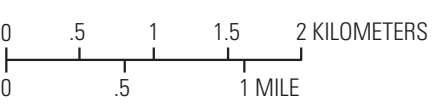

Base from U.S. Geological Survey digital data, 1:1,000,000, 2018 Geographic projection, decimal degrees

North American Datum of 1927

Geology modified from Drewes (1971a), Quinlan $(1981,1986)$ and Simons (1974).

Figure 117. Distribution of magnesium in mesquite ash. 


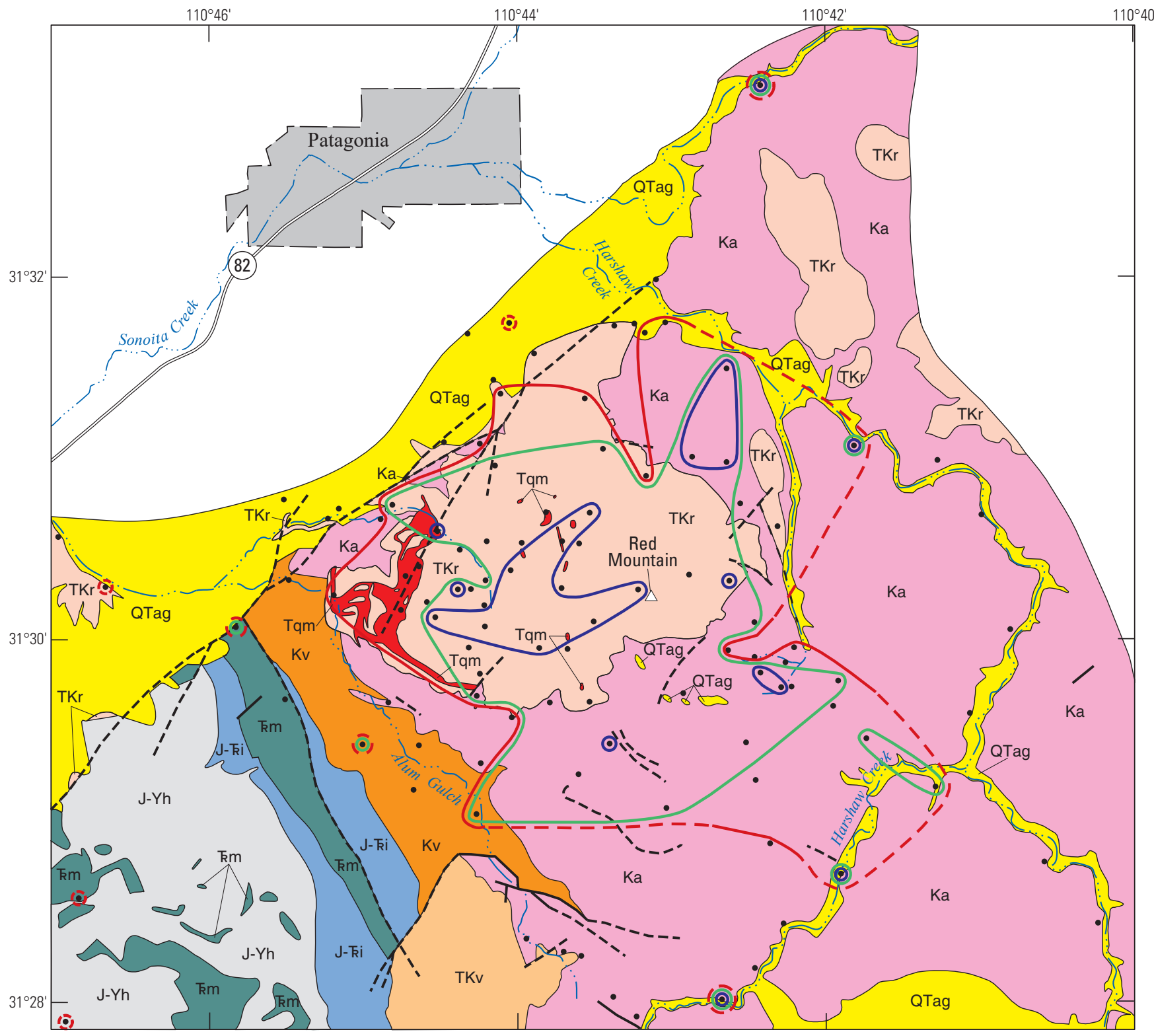

Figure 118. Distribution of magnesium in oak ash.

\section{EXPLANATION}

QTag Alluvium and terrace gravels, undivided

Quartz monzonite porphyryIntrusive rocks

TKr Volcanics of Red Mountain - Chiefly rhyolite tuff. Drewes, 1971a; 1972

TKv Felsic volcanic rocks-Chiefly latite

Ka Trachyandesite of Meadow ValleyChiefly andesite porphyry. Simons, 1972

Kv Silicic volcanics-Simons, 1974

J-ki Plutonic and volcanic rocks, undivided

Mount Wrightson Formation-Chiefly felsic volcanics

$\mathrm{J}-\mathrm{Yh}$ Hornblende-rich metamorphic and

$$
\text { igneous rocks, undivided }
$$

Contact-Locally concealed or

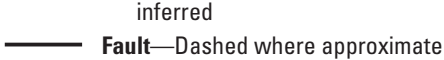
or inferred

Distribution of magnesium in oak ash, in percent-Contours are shown with a solid line where the sample density is high. Where sample density is low, the contours are dashed

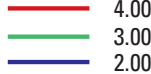

- Sample site

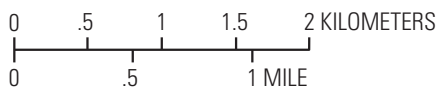

Base from U.S. Geological Survey digital data, 1:1,000,000, 2018 Geographic projection, decimal degrees North American Datum of 1927 


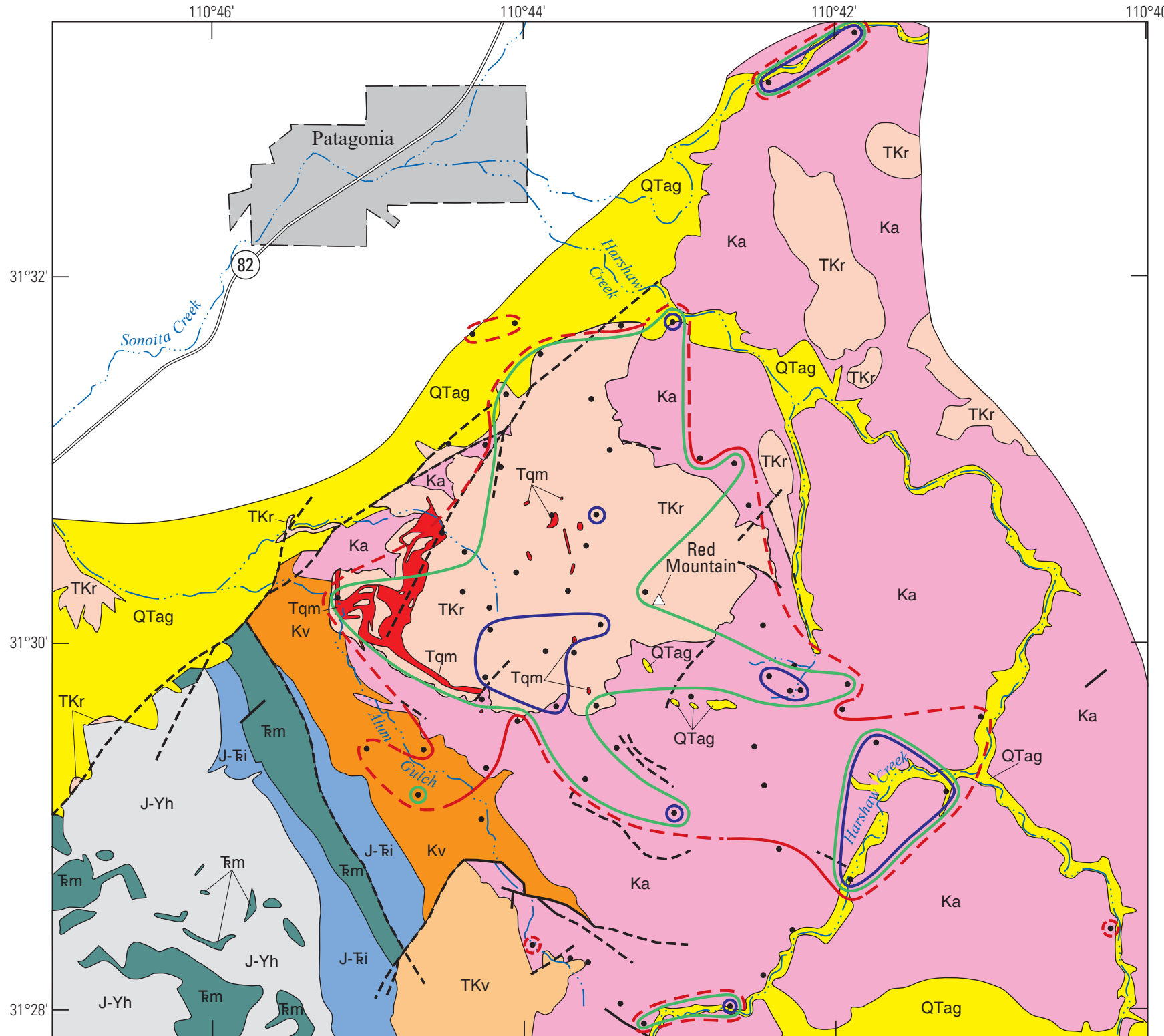

Figure 119. Distribution of magnesium in juniper ash

\section{EXPLANATION}

QTag Alluvium and terrace gravels, undivided

Quartz monzonite porphyryIntrusive rocks

TKr Volcanics of Red Mountain-Chiefly rhyolite tuff. Drewes, 1971a; 1972

TKv Felsic volcanic rocks-Chiefly latite

$\mathrm{Ka}$ Trachyandesite of Meadow ValleyChiefly andesite porphyry. Simons, 1972

Kv Silicic volcanics-Simons, 1974

$\mathrm{J}-\mathrm{Ki}$ Plutonic and volcanic rocks, undivided

Mount Wrightson Formation-Chiefly felsic volcanics

$\mathrm{J}$-Yh Hornblende-rich metamorphic and igneous rocks, undivided Contact-Locally concealed or inferred

Fault-Dashed where approximate or inferred

Distribution of magnesium in juniper ash, in percent-Contours are shown with a solid line where the sample density is high. Where sample density is low, the contours are dashed

5.00
$-\quad 4.00$
3

5.00
3.00

- Sample site

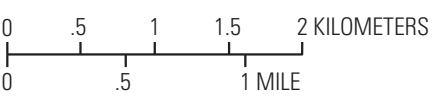

Base from U.S. Geological Survey digital data, 1:1,000,000, 2018 Geographic projection, decimal degrees North American Datum of 1927

Geology modified from Drewes (1971a), Quinlan (1981, 1986 and Simons (1974). 
Applications of Geochemical and Mineralogical Analyses to Geologic Mapping, Mineral Deposit Genesis and Models, Distribution and Zoning of Elements and Minerals, Exploration for Mineral Deposits, and Environmental Investigations

Many different topics can be investigated for a mineral deposit. For the Red Mountain PCD, authors have described host-rock geology (Drewes, 1971a; 1972; 1996; Quinlan, 1981; 1986; Simons, 1972; 1974); the Red Mountain mineral deposit (Lecumberri-Sanchez and others, 2013; Quinlan, 1981; 1986; Vikre and others, 2014); ages of host rock formations and mineralization (Drewes, 1971a; 1972; Vikre and others, 2014); remote sensing and alteration (Berger and others, 2003); vein structure (Kistner, 1984); and fluid inclusions (Bodnar and Beane, 1980; Lecumberri-Sanchez and others, 2013). The current study emphasizes and discusses the concentrations and distributions of selected elements and minerals in the subsurface and of elements in rocks, soils, and plants over the deposit.

Element concentrations and distributions complement other parameters that can be determined for a PCD. Elements are commonly not mineral specific, and unlike mineral phases, do not provide data such as pressure and temperature of formation of the deposit. However, the concentrations and distributions do locate areas of enrichment and depletion and can show the results of the multiple events in the formation of a given deposit.

For most of the elements discussed here, the concentrations are based on a near-total analysis. Thus, one cannot distinguish between oxidation states and their differing mobilities. Element concentrations and distributions do, however, provide base line information that is particularly useful for mining feasibility, exploration, and environmental studies.

The timing of events that formed the Red Mountain PCD are not completely established. Not resolved is the apparent difference between the age of the mineralizing events and the age of the quartz monzonite porphyry bodies. The differences in ages determined for these intrusions and the copper-related alteration (about $62 \mathrm{Ma}$ compared to $60 \mathrm{Ma}$ ) (Vikre and others, 2014) would imply that the emplacement of the intrusive bodies is not associated with formation of the Red Mountain PCD. However, the close spatial association of the surface and subsurface locations of quartz monzonite porphyry and high concentrations of copper and other deposit-related elements, suggests at least a probable temporal relation.

\section{Core}

As part of this study, as many as 44 elements and 13 minerals were determined in core samples. The concentrations and distributions of both elements and XRD-determined minerals provide important information not readily obtainable from core logging. These data are also independent of any biases of different individuals logging the same or similar core. Although the mineral data have little temporal value, they help in interpreting mineral zoning.

Factor analysis is used here to classify the mineral-depositrelated elements into groups that may represent different events and (or) zones resulting from mineralization and alteration processes. This mathematical technique thus helps separate the chemical associations related to lithology (1) from those related to hypogene events and (2) from those related to supergene enrichment and later weathering. The element associations determined by factor analysis can also sometimes identify which trace and minor elements are probably substituting in the structures of visible minerals.

Factor analysis was run with 34 elements on a hypogene dataset that includes samples from the deep part of the deposit and on a supergene dataset with samples from the area of most intense supergene enrichment that includes both hypogene- and supergene-related elements and minerals. The results show that four factors classify the hypogene mineral deposit associations. These four factors include (1) Ag, Cu, S, Te, and Mo; (2), Mn, $\mathrm{Zn}$, and $\mathrm{Pb}$; (3) $\mathrm{Au}$ and $\mathrm{Na}$; and (4) Sb, As, B, and $\mathrm{Hg}$. Another factor includes potassium and thallium, which are related to potassic alteration. Three deposit-related factors classify the supergene zone: (1) $\mathrm{Sb}, \mathrm{Hg}, \mathrm{Pb}, \mathrm{As}, \mathrm{Ag}$, and Tl; (2) $\mathrm{Cu}, \mathrm{Mo}, \mathrm{Te}$, and $\mathrm{S}$; and (3) Au and $\mathrm{Na}$. An additional factor contains potassium and rubidium, which are related mostly to potassium-rich alteration minerals.

The fact that all of the elements related to altered and mineralized rocks can be classified into separate groups is important. In an earlier study, a regional multielement soil survey was conducted in the vicinity of Eureka, Nevada, an area with a history of overlapping mineralizing events. Factor analysis successfully identified and classified two suites of elements: a silver-rich base-metal suite $(\mathrm{Ag}, \mathrm{Cu}, \mathrm{Pb}, \mathrm{Sb}$, and $\mathrm{Zn}$ ) of the Cretaceous Period and a Carlin-type gold suite (Au, As, $\mathrm{Hg}$, and $\mathrm{Sb}$ ) of the Tertiary Period (Chaffee, 1987; Shawe and Nolan, 1989).

Because all the deposit-related elements at Red Mountain are not loaded on just one or possibly two factors, one can speculate that their separation into four or five different factors is partly a result of separate mineralizing events and (or) partly due to the effects of different spatial and (or) concentration zoning of the respective elements represented in each of these factors.

A comparison of the element associations between the hypogene and supergene factors illustrates changes in associations due partly to different mineral species at different levels of 
the deposit, partly to addition or depletion of certain elements as a result of supergene and later weathering events, and partly to differences in the bulk pre-mineralization chemistry of the rhyolite tuff and andesite lithologies. As examples, zinc in the hypogene zone is associated with a deposit-related factor that includes lead and manganese. Because of different chemical mobilities, zinc has been leached in the supergene zone while lead has not. Thus, zinc becomes associated with lithology-related elements that are present in comparatively low concentrations in the rhyolite tuff-dominated supergene zone.

In the hypogene zone, silver and lead are associated with copper and zinc, respectively. In the supergene zone, lead is associated with silver, arsenic, mercury, antimony, and thallium. probably in lead-rich base-metal sulfide or sulfate minerals. Some of these new associations are a result of formation of several suites of hypogene minerals in the deep part of the deposit and different hypogene mineral suites in the peripheral part of the deposit. Some changes may be a result of the effects of supergene processes.

Element and mineral distributions can be classified into zones in the Red Mountain deposit. Present in the copper-poor "barren" core in the deep part of the Cu-Mo deposit (fig. 5) are relatively low concentrations of copper and other copper-related elements, including silver, arsenic, gold, molybdenum, sulfur, antimony, tellurium, and thallium, and only sparse distributions of pyrite, calcite, and chlorite. This core area is characterized by relatively high concentrations of calcium, manganese, sodium, plagioclase, and magnetite.

The distributions of elements in the mid-level to deep part of the hypogene deposit project in cross section as two limbs in the general area of intrusive lenses of quartz monzonite porphyry (figs. 3 and 5). These limbs are part of a crude, inverted, cup-shaped shell (Quinlan, 1986) that is typical of many PCDs. Based on observations of crosscutting vein sets, the deposit was formed during several separate mineralizing events that produced a PCD that is confined mostly to the andesite unit but continues locally upward to the present top of the overlying rhyolite tuff unit. For some elements, their concentrations differ markedly between the two limbs of the cup-shaped shell. Because no deposit is perfectly symmetrical, such differences are to be expected.

Elements most closely associated spatially with the potassic alteration zone and the deep part of the hypogene $\mathrm{Cu}-\mathrm{Mo}$ deposit include $\mathrm{Ag}, \mathrm{Au}, \mathrm{K}$, Mo, total S, sulfate $\mathrm{S}, \mathrm{Sb}, \mathrm{Te}$, and $\mathrm{Tl}$, with weaker spatial associations of $\mathrm{As}, \mathrm{B}, \mathrm{Hg}, \mathrm{Pb}$, and $\mathrm{Zn}$. Minerals spatially associated with this part of the deposit include chalcopyrite, molybdenite, pyrite, orthoclase, biotite, magnetite, calcite, quartz, and anhydrite.

Minerals representing other classic zones associated with PCDs are also present above the deep part of the hypogene deposit and its potassic alteration mineral assemblage at Red Mountain. The phyllic zone is represented by pyrite, sericite, and quartz. The advanced argillic zone, which is mostly confined to the rhyolite tuff unit, is typical of those described for other PCDs and includes the minerals enargite, tennantite, alunite, pyrophyllite, kaolinite, quartz, tourmaline, and barite (Guilbert and Park, 1986; Gustafson and Hunt, 1975; Hemley and Jones, 1964; Hemley and others, 1969; Knight, 1977; Sillitoe, 1983). These three major alteration zones generally overlap and thus do not exhibit well-defined boundaries.

Supergene enrichment and subsequent weathering altered many of the hypogene elements and minerals. Supergene enrichment produced extensive chalcocite deposition. Chalcocite, which occurs mainly as coatings on pyrite but also as veinlets filling fractures, is most highly concentrated in a blanket deposit, which is defined by the 1,000 and 2,000 ppm copper contours, and is present in the rhyolite tuff unit vertically above the deep part of the Cu-Mo deposit (fig. 5). As seen in the section, the effects of the circulating fluids related to this event extended from the present surface downward for a distance of about $1,220 \mathrm{~m}$ for many elements and minerals on the east side of the section in the vicinity of drill hole 158 , traversing the rhyolite tuff unit and well into the andesite unit.

Deposit-related elements that are concentrated in the area of the supergene zone and (or) above that zone include Ag, As, $\mathrm{Au}, \mathrm{B}, \mathrm{Bi}, \mathrm{Co}, \mathrm{Cu}, \mathrm{Hg}, \mathrm{Mo}, \mathrm{Pb}, \mathrm{S}, \mathrm{Sb}, \mathrm{Sn}, \mathrm{Te}, \mathrm{Tl}, \mathrm{U}$, and $\mathrm{W}$. The only deposit-related element that has clearly been leached in this upper part of the system is zinc. With the exception primarily of copper and possibly mercury and uranium, these concentrations in the area affected by supergene enrichment indicate that most of these elements have relatively low chemical mobilities in this environment at Red Mountain. Because most of these elements are hypogene in origin and are essentially in their original locations at the top of the deposit, they should be especially effective to use in both reconnaissance and detailed geochemical surveys conducted in areas affected by similar metallogenic events and climatic environments. Many of these same elements are present in the peripheral zones of other PCDs.

Subsequent to supergene enrichment, near-surface chemical weathering produced a leached cap consisting of pervasive hematite and other iron oxides in the uppermost part of the rhyolite tuff unit. These minerals formed primarily as a result of the oxidation of pyrite. This event was accompanied by considerable losses of cobalt, mercury, magnesium, zinc, and possibly other elements, as well as the destruction of sericite, plagioclase, pyrite, clay minerals, and pyrophyllite. No copper oxide minerals have been observed in the leached cap area. If present, they are rare.

The distributions of some of the elements and minerals determined for this study can help locate the contacts between the andesite and rhyolite tuff formations. This contact is sometimes difficult to identify in subsurface core samples and to some extent in surface rock samples because of intense alteration effects. The best elements for defining this contact are calcium, magnesium, manganese, and sodium. The upper limits of the 
distributions of biotite, magnetite, and calcite also help to define this contact except where later events have destroyed these minerals. Where biotite has been altered to chlorite, the upper limit of chlorite occurrences marks the contact (fig. 37).

The presence of low but anomalous concentrations of mercury in the deep hypogene part of the Cu-Mo deposit, along with evidence of anomalous mercury in the upper parts of the system directly above the deep part of the deposit (fig. 14), suggest that mercury, and possibly other volatile elements and compounds, warrant consideration in geochemical exploration surveys looking for deep-seated mineral deposits.

Although tellurium has been recovered in the processing of PCD ores from some deposits, its distribution has not been adequately appreciated as a pathfinder element in the search for PCDs. The high median values for tellurium in core, rock, and soil samples, and high ratio values relative to estimated threshold concentrations in andesite samples are noteworthy. The high concentrations of tellurium at Red Mountain tend to form a widespread halo well outside the deep and mid-level parts of the Red Mountain deposit (fig. 9), a zoning first noted by Gott and McCarthy (1966) for the Ely, Nevada, copper deposit. Additionally, the regional stream-sediment survey of the Patagonia Mountains (Chaffee and others, 1981) revealed high concentrations of tellurium in the vicinity of Red Mountain. Tellurium is relatively immobile in the weathering environment so that its halo remains even when other deposit-related elements have been leached or dispersed. The high incidence of PCDs in southern Arizona imply that this region is a tellurium-rich metallogenic province. Thus, the regional distribution of this element may be a useful exploration guide in the search for undiscovered PCDs.

\section{Rock and Soil}

A total of 122 rock and 119 soil samples were analyzed for this study. The concentrations and distributions of selected elements in these samples (1) provide information about the surface expression of the Red Mountain deposit, and (2) provide element databases useful for both exploration and environmental purposes.

Although the rock and soil distributions provide a good indication of what is actually anomalous on the surface of the Red Mountain deposit and in the surrounding area, the boundary line defining the limit of visible alteration (fig. 41) also helps to define and explain the areas containing anomalous concentrations of various elements that are related to this deposit.

Most of the rock samples collected outside this boundary did not appear to be visually altered. Thus, it was somewhat surprising to find "anomalies" for some mineral deposit-related elements - notably copper but also including cadmium, iron, molybdenum, and zinc - in the rock samples collected in the vicinity of the major drainages surrounding Red Mountain. Most of these "anomalous" samples are from the andesite unit. The lateral extent of anomalous copper at depth is unknown but extends to the right (east) of the area of drill hole 158 (fig. 5).
The core from this drill hole includes many samples that contain copper concentrations exceeding $100 \mathrm{ppm}$. These anomalous concentrations could extend to the area of the Harshaw Creek drainage.

Taylor (1969) reports typical copper concentrations in andesites ranging as high as $60 \mathrm{ppm}$. The summaries by Wedepohl (1974) of the copper content of andesites show a range of 3 to $150 \mathrm{ppm}$, with average values between 34 and $67 \mathrm{ppm}$ and an arithmetic mean value of $55 \mathrm{ppm}$. Thus, at least some of the high copper contents in the andesite samples collected east of Red Mountain could be the result of unusually copper-rich andesitic rocks.

Mining for base and precious metals has occurred throughout the Patagonia Mountains since the late 1800s (Schrader, 1915). In the past, little attention was given to controlling contamination. As a result, the major drainages surrounding Red Mountain are highly contaminated with mineralized material related to past mining (Chaffee and others, 1981). This contamination is apparently reflected in the rock and soil samples collected in and near these drainages. Contamination may also result from erosion of exposures of altered rocks and soils from higher on Red Mountain. Thus, it is likely that such soil and sediment has been dispersed by gravity, winds, rain, or possibly flash-flood waters and has locally contaminated the rock surfaces where the samples were collected in spite of an effort during sampling to remove any visibly altered surface material from each sample.

The distributions of the deposit-related elements Ag, As, $\mathrm{Bi}, \mathrm{Cu}, \mathrm{Fe}, \mathrm{Mo}, \mathrm{Pb}, \mathrm{Sb}, \mathrm{Te}$, and $\mathrm{Tl}$ in rock and soil samples show positive anomalies within and adjacent to the boundary of the area containing visibly altered rock. Within the boundary, many of these deposit-related elements exhibit anomalies spatially related to exposures of one or both of two centers of quartz monzonite porphyry. The easternmost center contains a cluster of scattered small outcrops of this formation that crop out directly above the deep part of the hypogene $\mathrm{Cu}-\mathrm{Mo}$ deposit. The westernmost center is associated with the largest area of quartz monzonite porphyry outcrops. However, no holes were drilled in this westernmost center, and thus no drill core was available to test for the presence or absence of an extension of the hypogene deposit below this location.

In addition to the positive anomalies noted above, some elements in the rock and soil samples $(\mathrm{Ca}, \mathrm{Cd}, \mathrm{Co}, \mathrm{K}, \mathrm{La}, \mathrm{Mg}$, $\mathrm{Mn}, \mathrm{Na}$, and $\mathrm{Zn}$ ) exhibit negative anomalies on the surface above the area of the hypogene deposit. Of these, cadmium, cobalt, and zinc are related to the deposit and have been leached from the near surface during supergene enrichment or during formation of the leached cap. In contrast, the negative anomalies of $\mathrm{Ca}, \mathrm{K}, \mathrm{La}, \mathrm{Mg}, \mathrm{Mn}$, and Na mostly reflect the bulk pre-mineralization chemistry of the rhyolite tuff unit as compared to that of the underlying andesite unit. 


\section{Vegetation}

The ash of 57 mesquite, 108 oak, and 68 juniper samples were analyzed for this study. The concentrations and distributions of selected elements in a plant can provide useful guidance in biogeochemical surveys conducted for mineral deposit exploration or for environmental studies.

Because of the relatively high relief present in the Red Mountain area, the three species of plants sampled were not evenly distributed throughout the study area. In areas of relatively low relief, such as the Lower Sonoran Life Zone, phreatophytes such as mesquite have proved useful in reconnaissance and detailed biogeochemical studies undertaken to find blind or poorly exposed copper deposits in low-relief pediment areas of Arizona that contain abundant drainage channels (Chaffee, 1976a; Huff, 1970).

Field studies by the author and many others indicate that mesquite is native throughout much of southern Arizona, southern New Mexico, and northern Mexico. This commonly riparian species is particularly useful as a sample medium near washes, where it is deep rooted and can tap the groundwater table. This groundwater may contain elements related to a blind mineral deposit.

Examination of the distribution of sample sites shows that mesquite, a common species in the Lower Sonoran Life Zone, is generally found growing only at lower elevations around Red Mountain, and thus grows mostly in areas underlain by andesite (for example, fig. 78). In contrast, oak and juniper trees, which are more common in the Upper Sonoran Life Zone, are less restricted by elevation and are found growing throughout most of the study area and over several different rock types (for example, figs. 79 and 80). These observations explain why it has been difficult in this study to define anomalies for many elements using mesquite samples.

Comparisons of concentrations of a given element in the ash of the three plant species (tables 6-8) show that the uptake of some elements varies substantially among the species. For example, median values for $\mathrm{Br}, \mathrm{Cs}$, and $\mathrm{Zn}$ in mesquite ash; median values for $\mathrm{Cd}, \mathrm{Co}, \mathrm{Li}, \mathrm{Mn}$, and $\mathrm{Ni}$ in oak ash; and the median value for Re in juniper ash are all much higher than the respective values of the other two species. These contrasting concentrations among the three species support the idea that plant genetics must play a role in element uptake. Faulty conclusions may thus occur if different species are combined in a vegetation survey. As a result, it is important in a biogeochemical survey to be able to identify specific species and to compile database on only one specific species at a time.

Of the elements analyzed, some (B, Ca, Cu, Fe, K, Mg, Mn, $\mathrm{Mo}, \mathrm{Na}, \mathrm{S}, \mathrm{Se}$, and $\mathrm{Zn}$ ) are known to be essential for plant growth when present in limited concentrations, and some $(\mathrm{Ag}, \mathrm{Co}, \mathrm{Li}$, and $\mathrm{U}$ ) are known to be nonessential (Brooks, 1983). Those elements analyzed for this study that can be severely toxic when present in significant concentrations include $\mathrm{Ag}, \mathrm{As}, \mathrm{Co}, \mathrm{Cu}, \mathrm{Pb}$, and $\mathrm{Tl}$. Those elements that can be moderately toxic include $\mathrm{Bi}$, $\mathrm{Cd}, \mathrm{Mn}, \mathrm{Mo}, \mathrm{Sb}, \mathrm{Se}, \mathrm{Sn}, \mathrm{U}, \mathrm{W}$, and $\mathrm{Zn}$. In spite of their potentially toxic effects, many of the deposit-related elements were taken up by the three species in high enough concentrations to produce positive anomalies over the deposit. These observations indicate that the deposit-related elements $\mathrm{Ag}, \mathrm{Cd}, \mathrm{Cu}, \mathrm{Mo}$, and $\mathrm{Zn}$ likely are the most useful for biogeochemical studies related to PCDs in environments such as that in the vicinity of Red Mountain. Past studies (Chaffee, 1976a; Huff, 1970) confirm these findings, at least for copper, molybdenum, and zinc in mesquite ash. Data are lacking in the literature for biogeochemical studies of oak and juniper. The concentration levels of these five deposit-related elements ( $\mathrm{Ag}, \mathrm{Cd}, \mathrm{Cu}, \mathrm{Mo}$, and $\mathrm{Zn}$ ) in the plants must not be high enough to poison these three species. Field observations in the Red Mountain vicinity did not identify any areas with clearly stunted trees or areas devoid of a given species that could be related to high concentrations of any of the elements determined for this study.

Comparisons of anomalies generated in the ash of the three plant species with those of the rock and soil samples show that some element anomalies in the plant ash are positive when the corresponding rock and (or) soil distributions show what appear to be negative anomalies. Again, plant genetics must play a part.

All three species produced anomalies related to the underlying Red Mountain deposit for most of the elements studied. Of the three species, the distributions in oak ash most consistently identified in detail the anomalies in the soil substrate.

The anomalies identified for the various elements in the ash of the three plant species are not substantially more widespread than those of the rock and soil samples. Vegetation sampling in the Red Mountain environment thus offers no obvious advantage as a sample medium for exploration purposes. From an environmental standpoint, however, the plant analyses provide baseline data that might be useful, for example, for selecting plant species for revegetating mine waste areas.

Anomalies for some elements in one or more species are also present in the Harshaw Creek drainage basin. As was the case for rock and soil samples, anomalies for at least some of the elements in plant samples from that area are almost certainly related to contamination from past mining.

Surface anomalies are present for many elements in rock, soil, and vegetation samples and include many potentially toxic elements. From an environmental standpoint, it is worth noting that, with the exception at Red Mountain of samples collected from sites in and near stream channels, these relatively high concentrations are natural, for the most part, and not caused by any past mining activity or other man-made activity. Thus, before the start of any mining venture, a thorough multielement geochemical survey can provide baseline data that characterize the natural distributions and abundances of elements of interest. These data can be used subsequently for environmental mitigation when mining is completed.

Because mineral and chemical zoning in mineral systems results from the physical and chemical processes responsible for the system, such zoning is generally present to some degree in the vicinity of most hydrothermal mineral deposits. The acquisition and interpretation of multielement chemical data, as well as mineralogical data, warrant consideration as an integral part in the study of most any kind of mineral system. The observations described in this report provide only a part of the information that could be obtained about the remarkably complete mineral deposit system at Red Mountain. 


\section{Conclusions}

Extensive core drilling at Red Mountain, Arizona, has delineated a large, deep seated, structurally intact porphyry copper-molybdenum deposit (Cu-Mo deposit or PCD) that extends from the present surface to depths of more than 1,765 meters. Unlike some other deposit types, porphyry $\mathrm{Cu}-\mathrm{Mo}$ deposits typically exhibit a well-documented pattern of element and mineral zoning. The distribution of elements and minerals determined for this study provide a zoning model of the Red Mountain system that can be applied to other PCDs and can aid in the search for new deposits. Multielement chemical information can thus be especially useful as part of an exploration program where only the less mineralized and less altered outer zones of an entire system are present or where the zones are not clearly exposed or are not recognized.

Following deposition of the thick sequence of predominantly felsic to andesitic volcanic host rocks at Red Mountain in the Late Cretaceous, several major events occurred to form the Red Mountain PCD during the early Tertiary. These events are recorded in the chemistry and mineralogy of core samples and reveal a complexly zoned hypogene system with multiple stages of chemical and mineralogical overprinting.

In spite of the depths to which the Red Mountain deposit has been explored, no associated pluton has yet been identified. Only small intrusive bodies have been found. The apparent difference in ages of the mineralizing events and the known quartz monzonite porphyry bodies has not been resolved. The differences in ages determined for these intrusions and the copper-related alteration - about 62 million years compared to 60 million years - would indicate that emplacement of the intrusive bodies is not associated with formation of the Red Mountain PCD. However, the close spatial association of the surface and subsurface locations of quartz monzonite porphyry and high concentrations of copper and other deposit-related elements, implies at least a probable temporal relation.

Samples of drill core, rock outcrops, soils, and three species of plants were collected and analyzed. Additional core samples were analyzed by X-ray diffraction for 13 minerals. The analyses show that the deep part of the hypogene deposit at Red Mountain consists of a potassic alteration zone that includes an arcuate zone of high copper concentrations in the form of a crude, inverted cup-shaped shell surrounding a relatively "barren" core that is typical of many PCDs. The two limbs of this shell contain anomalous but varying concentrations of silver (Ag), arsenic $(\mathrm{As})$, gold $(\mathrm{Au})$, boron $(\mathrm{B})$, copper $(\mathrm{Cu})$, potassium $(\mathrm{K})$, molybdenum $(\mathrm{Mo})$, lead $(\mathrm{Pb})$, total and sulfate sulfur $(\mathrm{S})$, antimony ( $\mathrm{Sb})$, tellurium (Te), thallium $(\mathrm{Tl})$, and zinc $(\mathrm{Zn})$. Minerals associated with the shell include chalcopyrite, bornite, molybdenite, pyrite, sphalerite, galena, orthoclase, biotite, magnetite, calcite, quartz, and anhydrite.

Higher in the system, several hypogene-related elements form broad, peripheral, flat to arcuate zones. These elements include $\mathrm{Ag}$, As, cobalt (Co), iron ( $\mathrm{Fe}$ ), $\mathrm{Pb}, \mathrm{Sb}, \mathrm{Te}, \mathrm{Tl}$, and $\mathrm{Zn}$. Near-surface restricted zones are present for bismuth (Bi), mercury (Hg), tin (Sn), and tungsten (W). Minerals concentrated in the phyllic alteration zone include pyrite, sericite, and quartz. Typical minerals in the advanced argillic zone include enargite, tennantite, alunite, pyrophyllite, clay minerals, quartz, tourmaline, and barite. Supergene enrichment re-mobilized hypogene copper and probably zinc and produced a blanket deposit of chalcocite and minor covellite. Subsequent weathering produced a leached cap zone in which hematite and other iron oxides replaced pyrite; molybdenite was locally altered to ferrimolybdite; cobalt, mercury, molybdenum, zinc, and possibly other elements were leached; and sericite, plagioclase, clay minerals, and pyrophyllite were destroyed. No copper oxide minerals have been observed. If present, they are rare. The near-surface part of the system also contains anglesite locally, which formed during supergene and (or) later weathering events. Other minerals related to these events are also probably present but have not been identified because they could not be easily identified as a result of the intense alteration in the upper part of the deposit.

Factor analysis helps classify the mineral-deposit-related elements into groups that may represent different episodes and (or) zones resulting from mineralization and alteration processes. This technique was run on a hypogene dataset that includes samples from the deep part of the deposit and on a supergene dataset with samples from the area of most intense supergene enrichment that includes both hypogene- and supergene-related elements and minerals. Five of the eight factors in the hypogene dataset have associations related to the mineral deposit: (1) Ag, Cu, S, Te and Mo; (2), manganese (Mn), Zn, and Pb; (3) Au and sodium (Na); (4) Sb, As, B, and $\mathrm{Hg}$; and (5) $\mathrm{K}$ and $\mathrm{Tl}$. Four of the eight factors in the supergene dataset have associations related to the mineral deposit: (1) $\mathrm{Sb}, \mathrm{Hg}, \mathrm{Pb}, \mathrm{As}, \mathrm{Ag}$, and Tl; (2) Cu, Mo, Te, and S; (3) $\mathrm{Au}$ and $\mathrm{Na}$; and (4) $\mathrm{K}$ and rubidium $(\mathrm{Rb})$. The changes in element associations between the two datasets mostly reflect changes in mineral species at different levels in the deposit.

The concentrations and distributions of selected elements in rock and soil samples (1) provide information about the surface expression of the Red Mountain deposit, and (2) provide element databases useful for both exploration and environmental projects.

Of the deposit-related elements studied, $\mathrm{Ag}, \mathrm{As}, \mathrm{Bi}, \mathrm{Cu}$, $\mathrm{Fe}, \mathrm{Mo}, \mathrm{Pb}, \mathrm{Sb}, \mathrm{Te}$, and $\mathrm{Tl}$ exhibit positive anomalies over the deposit in samples of both rock and soil. The highest concentrations for these elements are generally spatially associated with either one or both of two areas with exposures of the quartz monzonite porphyry. Zinc, cadmium, and cobalt exhibit negative anomalies that are the result of chemical leaching related to supergene and (or) weathering events. Other elements, such as calcium (Ca), $\mathrm{K}$, magnesium $(\mathrm{Mg}), \mathrm{Mn}$, and $\mathrm{Na}$, also exhibit negative anomalies, but these distributions are mainly the result of relatively low concentrations in the rhyolite tuff host rock as compared to the andesite unit.

The high concentrations of relatively immobile tellurium at Red Mountain, which mostly occur in a peripheral zone in the uppermost part of the system, and the high incidence of 
similar PCDs in southern Arizona, together suggest that this region is a tellurium-rich metallogenic province. Thus, the regional distribution of this element may be a useful exploration guide in the search for undiscovered PCDs.

The concentrations of many elements in samples of mesquite, oak, and juniper trees vary from one species to another, apparently because of genetic differences that largely determine whether a given element is essential, nonessential, or toxic to a plant. The high tolerance of oak trees to potentially toxic arsenic and lead is especially noteworthy.

The distributions of high concentrations of elements in the three plant species generally mimic those of their substrate soils. In spite of their potentially toxic effects, many of the deposit-related elements, including $\mathrm{Ag}, \mathrm{As}, \mathrm{Bi}$, cadmium (Cd), $\mathrm{Cu}, \mathrm{Mo}, \mathrm{Sb}$, and $\mathrm{Zn}$, were taken up by the three species in high enough concentrations to produce positive anomalies over the deposit.

Vegetation sampling in the Red Mountain environment offered no obvious advantage as a sample medium for exploration purposes. From an environmental standpoint, however, the plant analyses provide baseline data that might be useful, for example, for selecting plant species for revegetating mine waste areas.

Mining for base and precious metals has occurred throughout the Patagonia Mountains since the late 1800s. In the past, little attention was given to controlling contamination. As a result, the major drainages surrounding Red Mountain are highly contaminated with mineralized material related to past mining. This contamination is locally reflected in the rock, soil, and some plant samples collected in and near these drainages.

\section{References Cited}

ActLabs, 2000, 2000 Fee Schedule: ActLabs, Inc., Ancaster, Ontario, Canada, $21 \mathrm{p}$.

Ahrens, L.H., and Erlank, A.J., 1969, Bismuth, in Wedepohl, K.H., ed., Handbook of Geochemistry: New York, SpringerVerlag, v. II/5, p. 83-D-1 to 83-D-7.

Albuquerque, C.A.R., and Shaw, D.M., 1972, Thallium, in Wedepohl, K.H., ed., Handbook of Geochemistry: New York, Springer-Verlag, v. II/5, p. 81-D-1 to 81-G-2.

Armienta, M.A., Ongley, L.K., Rodriguez, R., Cruz, O., Mango, H., and Villasenor, G., 2008, Arsenic distribution in mesquite (Prosopis laevigata) and huizache (Acacia farmesiana) in Zimapan mining area, Mexico: Geochemistry, Exploration, Environment, Analysis, v. 8, p. 191-197.

Atapour, Habibeh, and Aftabi, Alijan, 2007, The geochemistry of gossans associated with Sarcheshmeh porphyry copper deposit, Rafsanjan, Kerman, Iran-Implications for exploration and the environment: Journal of Geochemical Exploration, v. 93, p. 47-65.
Berger, B.R., King, T.V.V., Morath, L.C., and Phillips, J.D., 2003, Utility of high-altitude infrared spectral data in mineral exploration-Application to northern Patagonia Mountains, Arizona: Economic Geology, v. 98, p. 1003-1018.

Bodnar, R.J., and Beane, R.E., 1980, Temporal and spatial variations in hydrothermal fluid characteristics during vein filling in preore cover overlying deeply buried porphyry copper type mineralization at Red Mountain, Arizona: Economic Geology, v. 75, p. 876-893.

Bolivar, S.L., Campbell, K., and Wecksung, G.W., 1983, $\mathrm{R}$-mode factor analysis applied to uranium exploration in the Montrose Quadrangle, Colorado, in Parslow, G.R., ed., Geochemical Exploration 1982: Journal of Geochemical Exploration, v. 19, p. 723-743.

Briggs, P.H., and Meier, A.L., 2002, The determination of forty-two elements in geological materials by inductively coupled-plasma-mass spectrometry, in Taggart, J.E., Jr., ed., Analytical methods for chemical analysis of geologic and other materials: U.S. Geological Survey Open-File Report 02-223, p. 11-14.

Brooks, R.R., 1983, Biological methods of prospecting for minerals: John Wiley and Sons, $322 \mathrm{p}$.

Brown, A.S., ed., 1976, Porphyry deposits of the Canadian Cordillera: The Canadian Institute of Mining and Metallurgy Special, v. 15, 510 p.

Butt, C.R.M., 1988, Genesis of lateritic and supergene gold deposits in the Yilgarn Block, Western Australia, in Smith, B.H., Stoakes, C.A., Govey, A.L., and Oates, C.J., compilers, Boddington and Eastern Goldfields, Western Australia—Prospecting in arid terrain, excursion guidebook: Perth, Australia, University of Western Australia, Publication No. 18, 84 p.

Candela, P.A., and Piccoli, P.M., 2005, Magmatic processes in the development of porphyry-type ore systems: Economic Geology, v. 100, p. 25-37.

Carson, D.J.T., Jambor, J.L., Ogryzlo, P., and Richards, T.A., 1976, Bell copper - Geology, geochemistry and genesis of a supergene enriched, biotitized porphyry copper deposit with a superimposed phyllic zone, in Brown, A.S., ed., Porphyry deposits of the Canadian Cordillera: Canadian Institute of Mining, Metallurgy Special Volume 15, $510 \mathrm{p}$.

Centanni, F.A., Ross, A.M., and DeSesa, M.A., 1956, Fluorometric determination of uranium: Analytical Chemistry, v. 28 , no. 11, p. 1651-1657.

Chaffee, M.A., 1976a, Geochemical exploration techniques based on distributions of selected elements in rocks, soils, and plants, Mineral Butte copper deposit, Pinal County, Arizona: U.S. Geological Survey Bulletin 1278-D, 55 p. 
Chaffee, M.A., 1976b, The zonal distribution of selected elements above the Kalamazoo porphyry copper deposit, San Manuel district, Pinal County, Arizona: Journal of Geochemical Exploration, v. 5, p. 145-165.

Chaffee, M.A., 1982, A geochemical study of the Kalamazoo porphyry copper deposit, Pinal County, Arizona, p. 211-225, in Titley, S.R., ed., Advances in geology of the porphyry copper deposits, southwestern North America: Tucson, University of Arizona Press, 560 p.

Chaffee, M.A., 1987, Application of R-mode factor analysis to geochemical studies in the Eureka Mining District and vicinity, Eureka and White Pine Counties, Nevada, in Elliott, I.L., and Smee, B.W., eds., GEOEXPO/86, Exploration in the North American Cordillera: Vancouver, Canada, Association of Exploration Geochemists, p. 94-108.

Chaffee, M.A., and Hessin, T.D., 1971, An evaluation of some geochemical sampling in the search for concealed 'porphyry' copper-molybdenum deposits on pediments in southern Arizona, in Boyle, R.W., and McGerrigle, J.I., eds., Geochemical exploration: Proceedings, 3rd International Geochemical Exploration Symposium, Toronto, April 16-18, 1970, The Canadian Institute of Mining and Metallurgy, Special Volume 11, 594 p.

Chaffee, M.A., Hill, R.H., Sutley, S.J., and Watterson, J.R., 1981, Regional geochemical studies in the Patagonia Mountains, Santa Cruz County, Arizona: Journal of Geochemical Exploration, v. 14, no. 2-3, p. 135-153.

Chaffee, M.A, Lasoń, Krzysztof, and Eppinger, Robert, 2001, Geochemical characteristics of the mineralized area, in Podemski, Maciej, ed., Palaeozoic porphyry molybdenum-tungsten deposit in the Myszków area, southern Poland: Warsaw, Poland, Polish Geological Institute Special Papers 6, 87 p.

Chang, Zhaoshan, Hedenquist, J.W., White, N.C., and others, 2011, Exploration tools for linked porphyry and epithermal deposits_Example from the Mankayan intrusion-centered $\mathrm{Cu}-\mathrm{Au}$ district, Luzon, Philippines: Economic Geology, v. 106, p. 1365-1398.

Chao, T.T., Sanzolone, R.F., and Hubert, A.E., 1978, Flame and flameless atomic-absorption determination of tellurium in geological materials: Analytica Chimica Acta, v. 96, p. 251-257.

Clarke, F.W., 1924, The data of geochemistry (5th ed.): U.S. Geological Survey Bulletin 770, 841 p. [Reprinted 1959]

Corn, R.M., 1975, Alteration mineralization zoning, Red Mountain, Arizona: Economic Geology, v. 70, p. 1437-1447.

Cox, D.P., 1985, Geology of the Tanama and Helecho porphyry copper deposits and vicinity, Puerto Rico: U.S. Geological Survey Professional Paper 1327, 59 p.
Cox, D.P., 1986, Descriptive model of porphyry $\mathrm{Cu}$, in Cox, D.P., and Singer, D.A., eds., Mineral deposit models: U.S. Geological Survey Bulletin 1693, 379 p.

Cox, L.J., Chaffee, M.A., Cox, D.P., and Klein, D.P., 1995, Porphyry $\mathrm{Cu}$ deposits, in du Bray, E.A., ed., Preliminary compilation of descriptive geoenvironmental mineral deposit models: U.S. Geological Survey Open-File Report 95-831, 242 p.

Crocket, J.H., 1974, Gold, in Wedepohl, K.H., ed., Handbook of Geochemistry, New York, Springer-Verlag, v. II/5, p. 79-F-1 to $79-\mathrm{F}-5$.

Davis, J.C., 1973, Statistics and data analysis in geology: New York, John Wiley \& Sons, 550 p.

Drewes, Harald, 1971a, Geologic map of the Mount Wrightson quadrangle, southeast of Tucson, Santa Cruz and Pima Counties, Arizona: U.S. Geological Survey, Miscellaneous Investigations Map I-614, scale 1:48,000.

Drewes, Harald, 1971b, Mesozoic stratigraphy of the Santa Rita Mountains, southeast of Tucson, Arizona: U.S. Geological Survey Professional Paper 658-C, p. C1-C81.

Drewes, Harald, 1972, Cenozoic rocks of the Santa Rita Mountains, southeast of Tucson, Arizona: U.S. Geological Survey Professional Paper 746, 66 p.

Drewes, Harald, 1996, Geologic maps of the southwestern part of Coronado National Forest, southeastern Arizona and southwestern New Mexico, in DuBray, E.A., ed., Mineral resource potential and geology of Coronado National Forest, southeastern Arizona and southwestern New Mexico: U.S. Geological Survey Bulletin 2083-A-K, plate 4, scale $1: 126,720$.

Dupont, Alain, Auwera, J.V., Pin, Christian, Marincea, Stefan, and Berza, Tudor, 2002, Trace element and isotope (Sr, Nd) geochemistry of porphyry- and skarn-mineralising Late Cretaceous intrusions from Banat, western South Carpathians, Romania: Mineralium Deposita, v. 37, p. 568-586.

Goldschmidt, V.M., 1954, [Muir, Alex, ed.], Geochemistry: Oxford, University Press, 730 p.

Gott, G.B., and McCarthy, J.H., Jr., 1966, Distribution of gold, tellurium, and mercury in the Ely Mining District, White Pine County, Nevada: U.S. Geological Survey Circular 535, 5 p.

Govett, G.J.S., 1983, ed., Rock geochemistry in mineral exploration: Handbook of Exploration Geochemistry, v. 3, New York, Elsevier Scientific Publishing Company, 461 p.

Graybeal, F.T., 1996, Sunnyside: A vertically-preserved porphyry copper system, Patagonia Mountains, Arizona: Society of Economic Geologists Newsletter, p. 1, and 10-14. 
Grimes, D.J., and Marranzino, A.P., 1968, Direct-current arc and alternating-current spark emission spectrographic field methods for the semiquantitative analysis of geologic materials: U.S. Geological Survey Circular 591, 6 p.

Guilbert, J.M., and Lowell, J.D., 1974, Variations in zoning patterns in porphyry ore deposits: CIM Bulletin, v. 67, no. 742, p. 99-109.

Guilbert, J.M., and Park, C.F., Jr., 1986, The geology of ore deposits: New York, W.H. Freeman and Company, 985 p.

Gunton, J.E., and Nichol, Ian, 1975, Chemical zoning associated with the Ingerbelle Copper Mountain mineralization, Princeton, British Columbia, in Elliott, I.L., and Fletcher, W.K., eds., Geochemical exploration 1974: Association of Exploration Geochemists Special Publication no. 2: New York, Elsevier Scientific Publishing Co., 720 p.

Gustafson, L.B., and Hunt, J.P., 1975, The porphyry copper deposit at El Salvador, Chile: Economic Geology, v. 70, no. 5, p. 857-912.

Gustafson, L.B., and Quiroga G., Jorge, 1995, Patterns of mineralization and alteration below the porphyry copper orebody at El Salvador, Chile: Economic Geology, v. 90, p. 2-16.

Hamaguchi, H., and Kuroda, R., 1969, Tin, in Wedepohl, K.H., ed., Handbook of Geochemistry, New York, SpringerVerlag, v. II/4, p. 50-D-1 to 50-D-6.

Harder, H., 1974, Boron, in Wedepohl, K.H., ed., Handbook of Geochemistry, New York, Springer-Verlag, v. II/1, p. 5-D-1 to $5-\mathrm{D}-6$.

Heier, K.S., and Billings, G.K., 1970a, Potassium, in Wedepohl, K.H., ed., Handbook of geochemistry, New York, SpringerVerlag, v. II/2, p. 19-D-1 to 19-D-5.

Heier, K.S., and Billings, G.K., 1970b, Rubidium, in Wedepohl, K.H., ed., Handbook of Geochemistry, New York, SpringerVerlag, v. II/4, p. 37-D-1 to 37-D-4.

Heier, K.S., and Billings, G.K., 1970c, Cesium, in Wedepohl, K.H., ed., Handbook of Geochemistry, New York, SpringerVerlag, v. II/4, p. 55-D-1.

Hemley, J.J., and Jones, W.R., 1964, Chemical aspects of hydrothermal alteration with emphasis on hydrogen metasomatism: Economic Geology, v. 59, p. 538-569.

Hemley, J.J., Hostetler, P.B., Gude, A.J., and Mountjoy, W.T., 1969, Some stability relations of alunite: Economic Geology, v. 64, p. 599-612.

Hopkins, D.M., 1977, An improved ion-selective electrode method for the rapid determination of fluorine in rocks and soils: U.S. Geological Survey Journal of Research, v. 5, no. 5, p. 589-593.
Horton, J.D., San Juan, C.A., and Chaffee, M.A., 2020, Data to accompany U.S. Geological Survey Scientific Investigations Report 2019-5077-Geochemical and mineralogical study of the Red Mountain porphyry copper-molybdenum deposit and vicinity, Santa Cruz County, Arizona: U.S. Geological Survey data release, https://doi.org/10.5066/P9BS56JZ.

Howarth, R.J., ed., 1983, Statistics and data analysis in geochemical prospecting: Handbook of exploration geochemistry, New York, Elsevier Scientific Publishing Company, v. 2, 437 p.

Hubert, A.E., and Lakin, H.W., 1973, Atomic absorption determination of thallium and indium in geologic materials, in Jones, M.J., ed., Geochemical Exploration 1972: Proceedings of the Fourth International Geochemical Exploration Symposium: London, Institution of Mining and Metallurgy, $458 \mathrm{p}$.

Huff, L.C., 1970, A geochemical study of alluvium-covered copper deposits in Pima County, Arizona: U.S. Geological Survey Bulletin 1312-C, p. C1-C31.

Jambor, J.L., 1974, Trace element variations in porphyry copper deposits, Babine Lake area, B.C.: Geological Survey of Canada Paper v. 74 no. 9, 30 p.

Jerome, S.E., 1966, Some features pertinent in exploration of porphyry copper deposits, in Titley, S.R., and Hicks, C.L., eds., Geology of the porphyry copper deposits, southwestern North America: Tucson, The University of Arizona Press, $287 \mathrm{p}$.

John, D.A., Ayuso, R.A., Barton, M.D., Blakely, R.J., Bodnar, R.J., Dilles, J.H., Gray, Floyd, Graybeal, F.T., Mars, J.C., McPhee, D.K., Seal, R.R., Taylor, R.D., and Vikre, P.G., 2010, Porphyry copper deposit model, chap. B of Mineral deposit models for resource assessment: U.S. Geological Survey Scientific Investigations Report 2010-5070-B, 169 p.

Kesler, S.E., 1973, Copper, molybdenum and gold abundances in porphyry copper deposits: Economic Geology, v. 68, p. 106-112.

Kistner, D.J., 1984, Fracture study of a volcanic lithocap, Red Mountain porphyry copper prospect, Santa Cruz County, Arizona: Tucson, University of Arizona, unpub. M.S. thesis, $75 \mathrm{p}$.

Knight, J.E., 1977, A thermochemical study of alunite, enargite, luzonite, and tennantite deposits: Economic Geology, v. 72 , p. $1321-1336$.

Lang, J.R., and Titley, S.R., 1998, Isotopic and geochemical characteristics of Laramide magmatic systems in Arizona and implications for the genesis of porphyry copper deposits: Economic Geology, v. 93, p. 138-170. 
Lasoń, Krzysztof, 2001, Geochemical patterns and pathfinders, in Podemski, Maciej, ed., Palaeozoic porphyry molybdenum-tungsten deposit in the Myszków area, southern Poland: Warsaw, Poland, Polish Geological Institute, Special Papers 6, 87 p.

Lecumberri-Sanchez, Pilar, Newton, M.C., III, Westman, E.C., Kamilli, R.J., Canby, V.M., and Bodnar, R.J., 2013, Temporal and spatial distribution of alteration, mineralization and fluid inclusions in the transitional high-sulfidation epithermal-porphyry copper system at Red Mountain, Arizona: Journal of Geochemical Exploration, v. 125, p. 80-93.

Levinson, A.A., 1974, Introduction to exploration geochemistry: Calgary, Canada, Applied Publishing Ltd., 612 p.

Levinson, A.A., 1980, Introduction to exploration geochemistry-The 1980 Supplement (2d ed.): Calgary, Canada, Applied Publishing Ltd., p. 615-924.

Lowell, J.D., and Guilbert, J.M., 1970, Lateral and vertical alteration-mineralization zoning in porphyry ore deposits: Economic Geology, v. 65, p. 373-408.

Markowiak, Marek, and Habryn, Ryszard, 2001, The spatial distribution of the mineralisation, in Podemski, Maciej, ed., Palaeozoic porphyry molybdenum-tungsten deposit in the Myszków area, southern Poland: Warsaw, Poland, Polish Geological Institute, Special Papers 6, 87 p.

Mason, Brian, and Moore, C.B., 1982, Principles of geochemistry (4th ed.) New York, John Wiley \& Sons, 344 p.

Mason, D.R., and McDonald, J.A., 1978, Intrusive rocks and porphyry copper occurrences of the Papua New Guinea-Solomon Islands region-A reconnaissance study: Economic Geology, v. 73, no. 5, p. 857-877.

McLemore, V.T., Munroe, E.A., Heizler, M.T., and McKee, Christopher, 1999, Geochemistry of the Copper Flat porphyry and associated deposits in the Hillsboro mining district, Sierra County, New Mexico, USA: Journal of Geochemical Exploration, v. 67, p. 167-189.

Meier, A.L., 1980, Flameless atomic-absorption determination of gold in geological materials: Journal of Geochemical Exploration, v. 13, no. 1, p. 77-85.

Monti, Richard, 1987, The Boddington lateritic gold deposit, Western Australia-A product of supergene enrichment processes, in Ho, S.E., and Groves, D.I., eds., Recent advances in understanding Precambrian gold deposits: Perth, University of Western Australia, Publication No. 11, 368 p.

Motooka, J.M., 1996, Organometallic extraction for 10 elements by inductively coupled plasma-atomic emission spectrometry, in Arbogast, B.F., ed., Analytical methods manual for the Mineral Resource Surveys Program, U.S. Geological Survey: U.S. Geological Survey Open-File Report 96-525, $248 \mathrm{p}$.
Motooka, J.M., and Grimes, D.J., 1976, Analytical precision of one-sixth order semiquantitative spectrographic analysis: U.S. Geological Survey Circular 738, 25 p.

O’Leary, R.M., 1990, Determination of sulfur in geologic materials by iodometric titration, in Arbogast, B.F., ed., Quality assurance manual for the Branch of Geochemistry, U.S. Geological Survey: U.S. Geological Survey Open-File Report 90-668, $184 \mathrm{p}$.

O’Leary, R.M., 1996, Tellurium and thallium by flame atomic absorption spectrometry, in Arbogast, B.F., ed., Analytical methods manual for the Mineral Resource Surveys Program, U.S. Geological Survey: U.S. Geological Survey Open-File Report 96-525, 248 p.

O'Leary, R.M., and Meier, A.L., 1986, Analytical methods used in geochemical exploration, 1984: U.S. Geological Survey Circular 948, 48 p.

Onishi, H., 1969, Arsenic, in Wedepohl, K.H., ed., Handbook of Geochemistry New York, Springer-Verlag, v. II/3, p. 33-D-1 to 33-D-7, 33-E-1 to 33-E-5, and 33-F-1 to $33-\mathrm{F}-2$.

Osatenko, M.J., and Jones, M.B., 1976, Valley Copper, in Brown, A.S., ed., Porphyry deposits of the Canadian Cordillera: Canadian Institute of Mining, Metallurgy Special Volume 15, $510 \mathrm{p}$.

Parker, R.L., 1967, Composition of the Earth's crust, in Fleischer, Michael, ed., Data of geochemistry, 6th edition, U.S. Geological Survey Professional Paper 440-D, p. D1-D19.

Pierce, F.W., and Bolm, J.G., eds., 1995, Porphyry copper deposits of the American Cordillera: Tucson, Arizona Geological Society Digest v. 20, 656 p.

Quinlan, J.J., 1981, Geology and silicate sulfide alteration zoning at the Red Mountain porphyry copper deposit, Santa Cruz County, Arizona: Arizona Geological Society and University of Arizona Field Trip Guide no. 8, 25 p.

Quinlan, J.J., 1986, Geology and silicate alteration zoning at the Red Mountain porphyry copper deposit, Santa Cruz County, Arizona, in Beatty, Barbara, and Wilkinson, P.A.K., eds., Frontiers in geology and ore deposits of Arizona and the Southwest: Arizona Geological Society Digest v. 16, $554 \mathrm{p}$.

Reimann, Clemens, and de Caritat, Patrice, 2000, Intrinsic flaws of element enrichment factors (EFs) in environmental geochemistry: Environmental Science \& Technology, v. 34, no. 24 , p. 5084-5091.

Reimann, Clemens, Filzmoser, P., Garrett, R.G., and Dutter, R., 2008, Statistical data analysis explained-Applied environmental statistics with R: West Sussex, England, John Wiley \& Sons, Ltd., 343 p. 
Reimann, Clemens, Filzmoser, Peter, and Garrett, R.G., 2002, Factor analysis applied to regional geochemical dataProblems and possibilities: Applied Geochemistry, v. 17, p. 185-206.

Richards, J.P., Boyce, A.J., and Pringle, M.S., 2001, Geologic evolution of the Escondida area, northern Chile-A model for spatial and temporal localization of porphyry $\mathrm{Cu}$ mineralization: Economic Geology, v. 96, p. 271-305.

Rieger, A.A., Marschik, Robert, Diaz, Manuel, Holzl, Stefan, Chiaradia, Massimo, Akker, Burc, and Spangenberg, J.E., 2010, The hypogene iron oxide copper-gold mineralization in the Mantoverde district, northern Chile: Economic Geology, v. 105, p. 1271-1299.

Rogers, J.J.W., and Adams, J.A.S., 1974, Uranium, in Wedepohl, K.H., ed., Handbook of geochemistry: New York, Springer-Verlag, v. II/5, p. 92-D-1 to $92-\mathrm{D}-5$.

Rudnick, R.L., and Gao, S., 2014, Composition of the continental crust, p. 1-51 in Rudnick, R.L., ed., The crust: treatise on geochemistry ( $2 \mathrm{~d}$ ed): Amsterdam, Elsevier Scientific Publishing Co., v. 4, Amsterdam, 806 p.

Schrader, F.C., 1915, Mineral deposits of the Santa Rita and Patagonia Mountains, Arizona, with contributions by J.M. Hill: U.S. Geological Survey Bulletin 582, 373 p.

Schroeter, T.G., ed., 1995, Porphyry deposits of the northwestern Cordillera of North America: Geological Society of the Canadian Institute of Mining, Metallurgy and Petroleum, Special Volume 46, 888 p.

Seedorff, Eric, Dilles, J.H., Proffett, J.M., Jr., Einaudi, M.T., Zurcher, Lukas, Stavast, W.J.A., Johnson, D.A., and Barton, M.D., 2005, Porphyry deposits - Characteristics and origin of hypogene features: Economic Geology, v. 100, p. 251-298.

Selinus, O., 1983, Factor and discriminant analysis to lithogeochemical prospecting in an area of central Sweden, in Parslow G.R., ed., Geochemical Exploration 1982: Journal of Geochemical Exploration, v. 19, p. 619-642.

Shacklette, H.T., 1972, Cadmium in plants: U.S. Geological Survey Bulletin 1314-G, p. G1-G28.

Shawe, D.R., and Nolan, T.B., 1989, Gold in the Eureka Mining District, Nevada, in Shawe, D.R., Ashley, R.P., and Carter, L.M.H., eds., Geology and resources of gold in the United States, Chapter C-Gold-bearing polymetallic veins and replacement deposits, part 1: U.S. Geological Survey Bulletin 1857, p. C27-C37.

Sillitoe, R.H., 1983, Enargite bearing massive sulfide deposits high in porphyry systems: Economic Geology, v. 78, p. 348-352.
Sillitoe, R.H., and Perelló, José, 2005, Andean copper province-Tectomagmatic settings, deposit types, metallogeny, exploration, and discovery: Economic Geology, v. 100, p. $845-890$.

Simons, F.S., 1972, Mesozoic stratigraphy of the Patagonia Mountains and adjoining area, Santa Cruz County, Arizona: U.S. Geological Survey Professional Paper 658-E, p. E1-E23.

Simons, F.S., 1974, Geologic map and sections of the Nogales and Lochiel quadrangles, Santa Cruz County, Arizona: U.S. Geological Survey Miscellaneous Investigation Series Map-I 762, scale 1:48,000.

Sindeeva, N.D., 1964, Mineralogy and types of deposits of selenium and tellurium: New York, Interscience Publishers, $363 \mathrm{p}$.

Stueber, A.M., 1976, Strontium, in Wedepohl, K.H., ed., Handbook of Geochemistry, New York, Springer-Verlag, v. II/4, p. $38-\mathrm{G}-1$ to $38-\mathrm{G}-3$.

Taylor, S.R., 1969, Trace element chemistry of andesites and associated calc-alkaline rocks, in McBirney, A.R., ed., Proceedings of the andesite conference: Portland, Oregon, Department of Geology and Mineral Industries, International Upper Mantle Project Scientific Report 16, 193 p.

Taylor, S.R., and McLennan, S.M., 1995, The geochemical evolution of the continental crust: Reviews of Geophysics, v. 33, no. 2, p. 241-265.

Teal, Lewis, and Benavides, Alberto, 2010, History and geologic overview of the Yanacocha Mining District, Cajamarca, Peru: Economic Geology, v. 105, p. 1173-1190.

Titley, S.R., ed., 1982, Advances in geology of the porphyry copper deposits, southwestern North America: Tucson, Arizona University Press, 560 p.

Titley, S.R., and Anthony, E.A., 1989, Laramide mineral deposits in Arizona, in Jenney, J.P., and Reynolds, S.J., eds., Geologic evolution of Arizona: Tucson, Arizona Geological Society Digest 17, $866 \mathrm{p}$.

Titley, S.R., and Hicks, C.L., eds., 1966, Geology of the porphyry copper deposits, southwestern North America: Tucson, University of Arizona Press, 287 p.

Turekian, K.K., and Wedepohl, K.H., 1961, Distribution of the elements in some major units of the Earth's crust: Geological Society of America Bulletin, v. 72, p. 175-192.

U.S. Geological Survey, 2018, The national map: U.S. Geological Survey, accessed April 16, 2018, at https://www. usgs.gov/core-science-systems/ngp/tnm-delivery/. 
Ulrich, Thomas, and Heinrich, C.A., 2002, Geology and alteration geochemistry of the porphyry $\mathrm{Cu}-\mathrm{Au}$ deposit at Bajo de la Alumbrera, Argentina: Economic Geology, v. 97, p. 1719-1742.

Vaughn, W.W., and McCarthy, J.H., Jr., 1964, An instrumental technique for the determination of submicrogram concentrations of mercury in soils, rocks, and gas: U.S. Geological Survey Professional Paper 501-D, p. D123-D127.

Vikre, P.G., 2010, Supergene ore characteristics-Section J, in John, D.A., ed., with contributions by Ayuso, R.A., Barton, M.D., and others, Porphyry copper deposit model, Chapter B of Mineral deposit models for resource assessment: U.S. Geological Survey Scientific Investigations Report 2010-5070-B, 169 p.

Vikre, P.G., Graybeal, F.T., Fleck, R.J., Barton, M.D., and Seedorf, Eric, 2014, Succession of Laramide magmatic and magmatic-hydrothermal events in the Patagonia Mountains, Santa Cruz County, Arizona: Economic Geology, v. 109, p. 1667-1704.

Ward, F.N., Nakagawa, H.M., Harms, T.M., and VanSickle, G.H., 1969, Atomic absorption methods useful in geochemical exploration: U.S. Geological Survey Bulletin 1289, 45 p.

Wedepohl, K.H., 1974, Copper, in Wedepohl, K.H., ed., Handbook of Geochemistry, New York, Springer-Verlag, v. II/3, p. 29-E-1 to 29-E-13.
Wedepohl, K.H., 1978, Manganese, in Wedepohl, K.H., ed., Handbook of Geochemistry, New York, Springer-Verlag, v. II/3, p. 25-D-1 to $25-\mathrm{D}-26$.

Wedepohl, K.H., ed., 1969-1978, Handbook of geochemistry: New York, Springer Verlag (loose leaf; each volume paginated by subject and element), v. II/1-5.

Wedepohl, K.H., 1995, The composition of the continental crust: Geochimica et Cosmochimica Acta, v. 59, no. 7, p. 1217-1232.

Welsch, E.P., 1979, Determination of arsenic in geologic materials with silver diethyldithiocarbamate: U.S. Geological Survey Open-File Report 79-1442, 10 p.

Welsch, E.P., 1983, A rapid geochemical spectrophotometric determination of tungsten with dithiol: Talanta, v. 30, no. 11, p. $876-878$.

Welsch, E.P., and Chao, T.T., 1975, Determination of trace amounts of antimony in geological materials by atomic absorption spectrometry: Analytica Chimica Acta, v. 76, p. 65-69.

Welsch, E.P., and Chao, T.T., 1976, Determination of trace amounts of tin in geological materials by atomic-absorption spectrometry: Analytica Chimica Acta, v. 82, p. 337-342.

Yan, Mingcai, and Chi, Qinghua, 2005, The chemical compositions of the continental crust and rocks in the eastern part of China: Beijing, China, Science Press, 171 p.

Publishing support provided by the Science Publishing Network, Denver Publishing Service Center

For more information concerning the research in this report, contact the

Center Director, USGS Geology, Geophysics, and Geochemistry

Science Center

Box 25046, Mail Stop 973

Denver, CO 80225

(303) 236-1800

Or visit Geology, Geophysics, and Geochemistry Science Center website at

https://www.usgs.gov/centers/gggsc 

